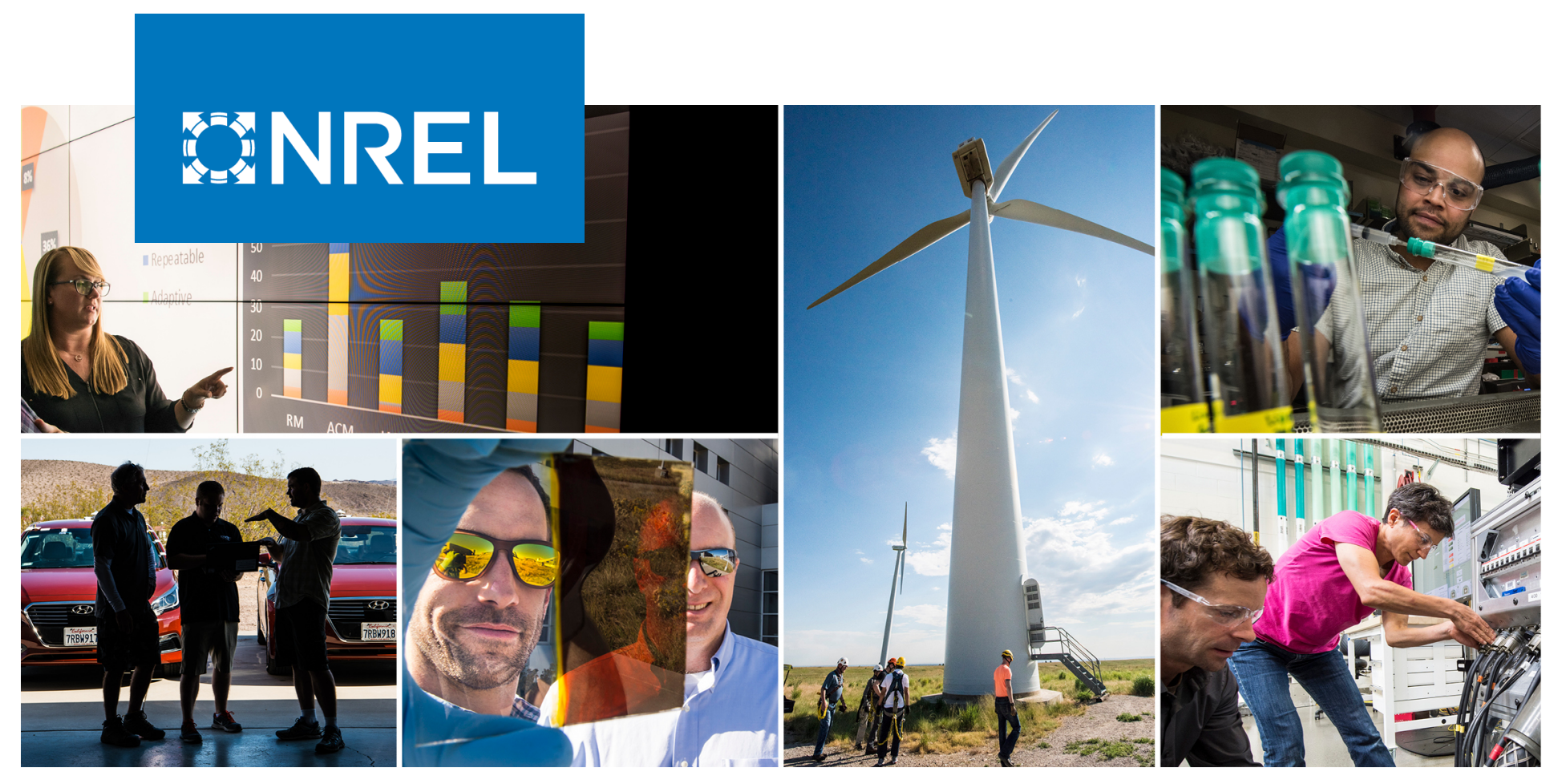

\title{
U.S. Solar Photovoltaic System and Energy Storage Cost Benchmark: Q1 2020
}

David Feldman, Vignesh Ramasamy, Ran Fu, Ashwin Ramdas, Jal Desai, and Robert Margolis

National Renewable Energy Laboratory

NREL is a national laboratory of the U.S. Department of Energy Office of Energy Efficiency \& Renewable Energy

Operated by the Alliance for Sustainable Energy, LLC

This report is available at no cost from the National Renewable Energy Laboratory (NREL) at www.nrel.gov/publications.

\section{Technical Report}

NREL/TP-6A20-77324

January 2021 


\section{GNREL}

\section{U.S. Solar Photovoltaic System and Energy Storage Cost Benchmark: Q1 2020}

David Feldman, Vignesh Ramasamy, Ran Fu, Ashwin Ramdas, Jal Desai, and Robert Margolis

National Renewable Energy Laboratory

\section{Suggested Citation}

Feldman, David, Vignesh Ramasamy, Ran Fu, Ashwin Ramdas, Jal Desai, and Robert Margolis. 2021. U.S. Solar Photovoltaic System Cost Benchmark: Q1 2020. Golden, CO: National Renewable Energy Laboratory. NREL/TP-6A20-77324.

https://www.nrel.gov/docs/fy21osti/77324.pdf.

NREL is a national laboratory of the U.S. Department of Energy Office of Energy Efficiency \& Renewable Energy Operated by the Alliance for Sustainable Energy, LLC

This report is available at no cost from the National Renewable Energy Laboratory (NREL) at www.nrel.gov/publications.

Contract No. DE-AC36-08GO28308
Technical Report

NREL/TP-6A20-77324

January 2021

National Renewable Energy Laboratory 15013 Denver West Parkway Golden, CO 80401

303-275-3000 • www.nrel.gov 


\section{NOTICE}

This work was authored by the National Renewable Energy Laboratory, operated by Alliance for Sustainable Energy, LLC, for the U.S. Department of Energy (DOE) under Contract No. DE-AC36-08GO28308. Funding provided by the U.S. Department of Energy Office of Energy Efficiency and Renewable Energy Solar Energy Technologies Office. The views expressed herein do not necessarily represent the views of the DOE or the U.S. Government.

This report is available at no cost from the National Renewable Energy Laboratory (NREL) at www.nrel.gov/publications.

U.S. Department of Energy (DOE) reports produced after 1991 and a growing number of pre-1991 documents are available free via www.OSTI.gov.

Cover Photos by Dennis Schroeder: (clockwise, left to right) NREL 51934, NREL 45897, NREL 42160, NREL 45891, NREL 48097, NREL 46526.

NREL prints on paper that contains recycled content. 


\section{List of Acronyms}

$\mathrm{AC}$

ASP

BNEF

BOS

CA NEM

CdTe

$\mathrm{CF}$

CPI

$\mathrm{c}-\mathrm{Si}$

DC

DOE

EPC

FICA

GPRA

HVAC

ITC

LBNL

LCOE

LCOS

LCOSS

Li-ion

MACRS

MLPE

MM

$\mathrm{MW}_{\mathrm{AC}}$

$\mathrm{MW}_{\mathrm{DC}}$

NEC

NEM

NREL

O\&M

PERC

PII

PPA

PV

Q

SETO

SG\&A

TPO

USD

$\mathrm{V}_{\mathrm{DC}}$

$\mathrm{W}_{\mathrm{AC}}$

$\mathrm{W}_{\mathrm{DC}}$

$\mathrm{W}_{\mathrm{p}}$ alternating current

average selling price

Bloomberg New Energy Finance

balance of system

California Net Energy Metering

cadmium telluride

capacity factor

Consumer Price Index

crystalline silicon

direct current

U.S. Department of Energy

engineering, procurement, and construction

Federal Insurance Contributions Act

Government Performance and Reporting Act

heating, ventilating, and air conditioning

investment tax credit

Lawrence Berkeley National Laboratory

levelized cost of energy

levelized cost of storage

levelized cost of solar-plus-storage

lithium-ion

Modified Accelerated Cost Recovery System

module-level power electronics

million

megawatts alternating current

megawatts direct current

National Electrical Code

net energy metering

National Renewable Energy Laboratory

operation and maintenance

passivated emitter and rear cells

permitting, inspection, and interconnection

power-purchase agreement

photovoltaic(s)

quarter

Solar Energy Technologies Office (DOE)

selling, general, and administrative

third-party ownership

U.S. dollars

volts direct current

watts alternating current

watts direct current

watts peak 


\section{Executive Summary}

This report benchmarks U.S. solar photovoltaic (PV) system installed costs as of the first quarter of 2020 (Q1 2020). We use a bottom-up method, accounting for all system and project development costs incurred during installation to model the costs for residential, commercial, and utility-scale PV systems, with and without energy storage. We attempt to model typical installation techniques and business operations from an installed-cost perspective. Costs are represented from the perspective of the developer/installer; thus, all hardware costs represent the price at which components are purchased by the developer/installer, not accounting for preexisting supply agreements or other contracts. Importantly, the benchmark also represents the sales price paid to the installer. Therefore, it includes profit in the cost of the hardware ${ }^{1}$; the profit the installer/developer receives is reported as a separate cost category on top of all other costs to approximate the final retail price paid to the installer/developer. However, we do not include any additional profit, such as a developer fee or price gross-up, which is common in the marketplace. We adopt this approach owing to the wide variation in developer overhead and profit in all three sectors (residential, commercial, and utility-scale), where project pricing depends greatly on the region and project specifics such as local retail electricity rate structures, local rebate and incentive structures, competitiveness of the environment, and overall project or deal structures. Benchmarks also assume a business environment without any impact from novel coronavirus pandemic. Finally, our benchmarks are national averages calculated using average values across all states. Table ES-1 summarizes the first-order benchmark assumptions.

Table ES-1. Benchmark Assumptions

\begin{tabular}{lll}
\hline Unit & Description \\
\hline Values & 2019 U.S. dollars (USD)a & \\
$\begin{array}{l}\text { System } \\
\text { Sizes }\end{array}$ & $\begin{array}{l}\text { PV systems are quoted in direct current (DC) terms; inverter prices are converted by } \\
\text { DC-to-alternating current (AC) ratios; storage systems are quoted in terms of kilowatt- } \\
\text { hours or megawatt-hours (kWh or MWh) of storage or the number of hours of storage } \\
\text { at peak capacity. }\end{array}$ & Size Range \\
\hline PV Sector & Description & 4kW-7 kW \\
\hline Residential & Residential rooftop systems, monocrystalline silicon modules & $100 \mathrm{~kW}-2 \mathrm{MW}$ \\
Commercial & $\begin{array}{l}\text { Commercial rooftop with ballasted racking and fixed-tilt ground- } \\
\text { mounted systems, monocrystalline silicon modules }\end{array}$ & \\
\hline Utility-scale & $\begin{array}{l}\text { Ground-mounted systems, monocrystalline silicon modules, fixed- } \\
\text { tilt and one-axis tracking }\end{array}$ & $5-100 \mathrm{MW}$ \\
\hline
\end{tabular}

a The dollar-per-watt total cost values are benchmarked as three significant figures, because the model inputs, such as module and inverter prices, use three significant figures.

\footnotetext{
${ }^{1}$ Profit is one of the differentiators between "cost" (aggregated expenses incurred by a developer or installer to build a system) and "price" (what an end user pays for a system).
} 
Based on our bottom-up modeling, the Q1 2020 PV cost benchmarks are:

- $\$ 2.71$ per watt DC $\left(\mathrm{W}_{\mathrm{DC}}\right)$ (or $\$ 3.12 / \mathrm{W}_{\mathrm{AC}}$ ) for residential PV systems

- $\$ 1.72 / \mathrm{W}_{\mathrm{DC}}\left(\right.$ or $\$ 1.96 / \mathrm{W}_{\mathrm{AC}}$ ) for commercial rooftop PV systems

- $\$ 1.72 / \mathrm{W}_{\mathrm{DC}}\left(\right.$ or $\$ 1.91 / \mathrm{W}_{\mathrm{AC}}$ ) for commercial ground-mount PV systems

- $\$ 0.94 / \mathrm{W}_{\mathrm{DC}}\left(\right.$ or $\$ 1.28 / \mathrm{W}_{\mathrm{AC}}$ ) for fixed-tilt utility-scale PV systems

- $\$ 1.01 / \mathrm{W}_{\mathrm{DC}}\left(\right.$ or $\$ 1.35 / \mathrm{W}_{\mathrm{AC}}$ ) for one-axis-tracking utility-scale PV systems

- $\$ 26,153-\$ 28,371$ for a $7-\mathrm{kW}$ residential PV system with $3 \mathrm{~kW} / 6 \mathrm{kWh}$ of storage and $\$ 35,591-\$ 37,909$ for a $7-\mathrm{kW}$ residential PV system with $5 \mathrm{~kW} / 20 \mathrm{kWh}$ of storage

- \$2.07 million-\$2.13 million for a 1-MW commercial ground-mount PV system colocated with $600 \mathrm{~kW} / 2.4 \mathrm{MWh}$ of storage

- $\$ 171$ million-\$173 million for a 100-MW PV system colocated with $60 \mathrm{MW} / 240 \mathrm{MWh}$ of storage.

Figure ES-1 puts our Q1 2020 PV-only benchmark results in context with the results of previous National Renewable Energy Laboratory (NREL) benchmarking analyses. When comparing the results across this period (2010-2020), it is important to note that:

1. Values are inflation-adjusted using the 2019 Consumer Price Index (CPI). Thus, historical values from our models are adjusted and presented as real USD instead of nominal USD. In previous year's models, we inflation-adjusted values based on a partial year of CPI data. For example, in the Q1 2018 benchmark report (Fu, Feldman, and Margolis 2018), all values are quoted in 2018 USD; however, the inflation adjustment is based on the average CPI Index of Q1 2018 (January through March 2018). Because the benchmark reports are produced before the end of the calendar year, indexing them to the full-year average CPI in that year is not possible. To better correct for inflation, in this year's report, we quote values in previous year's dollars (2019 USD). In 2018, the CPI-All Urban Consumers Index is 248.8 for the first three months and 251.1 for the whole year (and 255.7 for 2019).

2. Cost categories are aggregated for comparison purposes. "Soft Costs-Others" represents permitting, inspection, and interconnection (PII); transmission line (if any); sales tax; and engineering, procurement, and construction (EPC)/developer overhead and profit. These costs are broken out in the report for each subsector.

3. The current versions of our cost models make a few significant changes from the versions used in our previous Q1 2018 benchmark report (Fu, Feldman, and Margolis 2018). To better distinguish the historical cost trends over time from the changes to our cost models, we also calculate Q1 2019 and Q1 2020 PV benchmarks using the Q1 2018 versions of the residential, commercial, and utility-scale PV models. Appendix A provides a detailed discussion of the changes made to the models between previous versions $(\mathrm{Fu}, \mathrm{Feldman}$, and Margolis 2018) and this year's versions.

4. Our Q1 2019 and Q1 2020 benchmarks use monocrystalline PV modules, whereas all historical benchmarks used multicrystalline PV modules. This switch reflects the overall trend occurring in the U.S. market.

5. For previous editions of this report, we assumed a land acquisition cost of $\$ 0.03 / \mathrm{W}$. Based on Wiser et al. (2020), which stated that most utility-scale PV projects do not own the land on which the PV system is placed, we have reclassified land costs from an upfront capital expenditure (land acquisition) to an operating expenditure (lease payments) for 2019 and 2020. 
From 2010 to 2020 , there was a $64 \%, 69 \%$, and $82 \%$ reduction in the residential, commercial rooftop, and utility-scale (one-axis) PV system cost benchmark, respectively. A significant portion of that reduction can be attributed to total hardware costs (module, inverter, and hardware balance of system [BOS]), with module prices dropping $85 \%$ over that period. Overall, modeled PV installed costs across the three sectors have experienced different recent changes. The inflation-adjusted system cost differences between Q1 2019 and Q1 2020 are a \$0.06/WDC reduction for residential $\mathrm{PV}$, a $\$ 0.04 / \mathrm{W}_{\mathrm{DC}}$ reduction for commercial rooftop $\mathrm{PV}$, and a $\$ 0.01 / \mathrm{W}_{\mathrm{DC}}$ reduction for utility-scale PV. Table ES-2 shows the benchmarked values for all three sectors and the drivers of cost decreases and increases. 
$\$ 9$

$\$ 8 \quad$ Residential PV (22 Panel System)

$\$ 7$

$\$ 6$

$\$ 5$

$\$ 4$

$\$ 3$

$\$ 2$

$\$ 1$
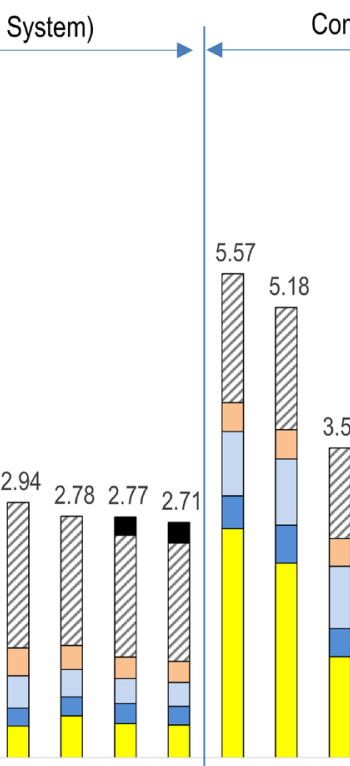

Commercial Rooftop PV (200 kW)

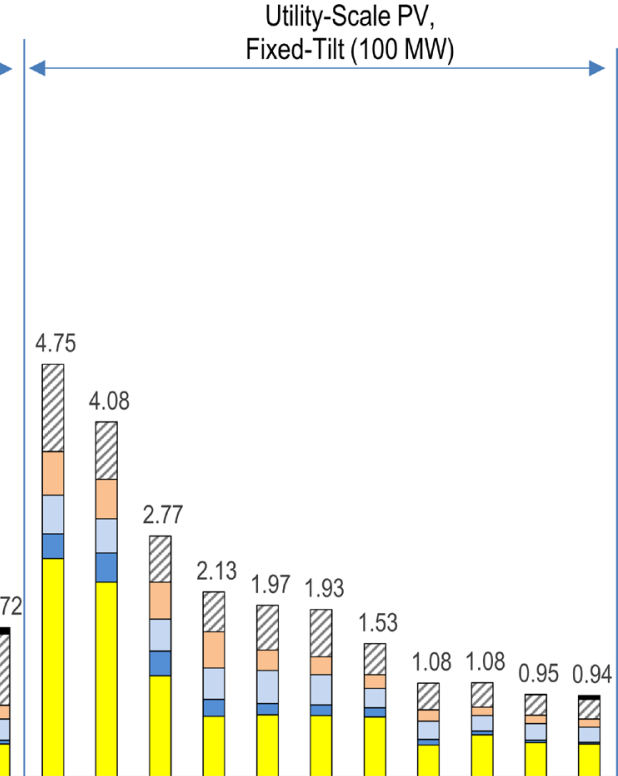

Utility-Scale PV,

One-Axis Tracker (100 MW)

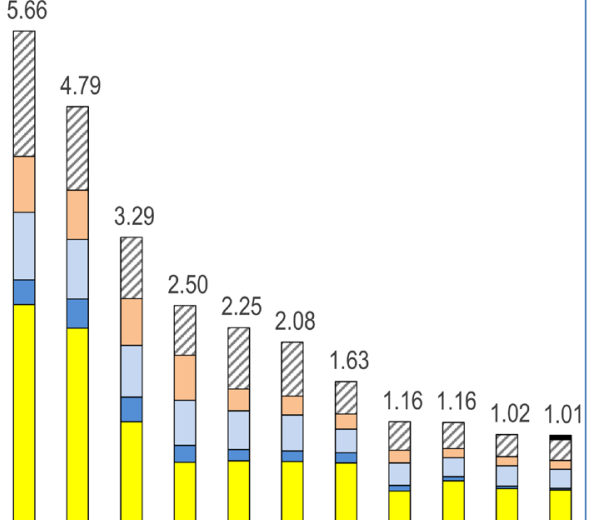

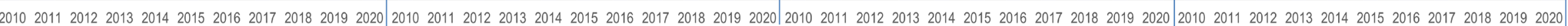

- Additional Costs from Model Updates

■ Soft Costs - Others (PII, Land Acquisition, Transmission Line, Sales Tax, Overhead, and Profit)

$\square$ Soft Costs - Install Labor

$\square$ Hardware BOS - Structural and Electrical Components

$\square$ Inverter

$\square$ Module

\section{Figure ES-1. NREL PV system cost benchmark summary (inflation-adjusted), 2010-2020}

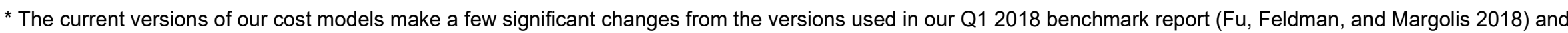

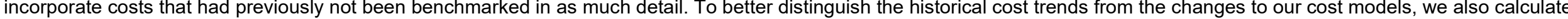

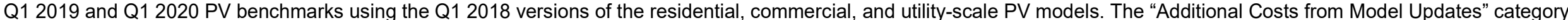

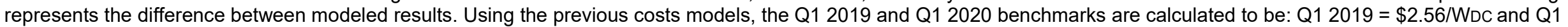

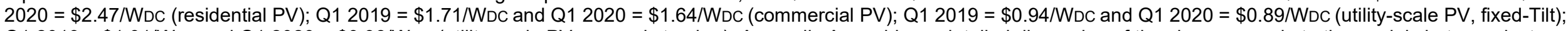

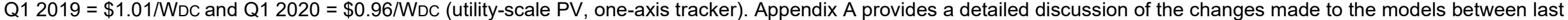
year's versions (Fu, Feldman, and Margolis 2018) and this year's versions. 
Table ES-2. Comparison of Q1 2019 and Q1 2020 PV System Cost Benchmarks

\begin{tabular}{|c|c|c|c|}
\hline Sector & Residential PV & $\begin{array}{l}\text { Commercial Rooftop } \\
\text { PV }\end{array}$ & $\begin{array}{l}\text { Utility-Scale PV, } \\
\text { One-Axis Tracking }\end{array}$ \\
\hline $\begin{array}{l}\text { Q1 } 2019 \\
\text { benchmarks in } \\
2019 \text { USD/WDC }\end{array}$ & $\$ 2.77$ & $\$ 1.76$ & $\$ 1.02$ \\
\hline $\begin{array}{l}\text { Q1 } 2020 \\
\text { Benchmarks in } \\
2019 \text { USD/WDC }\end{array}$ & $\$ 2.71$ & $\$ 1.72$ & $\$ 1.01$ \\
\hline $\begin{array}{l}\text { Drivers of cost } \\
\text { decrease }\end{array}$ & $\begin{array}{l}\text { - Higher module } \\
\text { efficiency (from } \\
19.2 \% \text { to } 19.5 \% \text { ) } \\
\text { - Decrease in BOS } \\
\text { hardware and supply } \\
\text { chain costs }\end{array}$ & $\begin{array}{l}\text { - Higher module } \\
\text { efficiency } \\
\text { - Lower material \& } \\
\text { equipment costs in } \\
\text { some categories }\end{array}$ & $\begin{array}{l}\text { - Higher module } \\
\text { efficiency } \\
\text { - Lower material \& } \\
\text { equipment costs in } \\
\text { some categories } \\
\text { - Movement of land } \\
\text { acquisition cost from } \\
\text { upfront capital } \\
\text { expenditures into } \\
\text { operation \& } \\
\text { maintenance }\end{array}$ \\
\hline $\begin{array}{l}\text { Drivers of cost } \\
\text { increase }\end{array}$ & $\begin{array}{l}\text { - Higher labor wages } \\
\text { - Higher module costs }\end{array}$ & $\begin{array}{l}\text { - Higher labor wages } \\
\text { - Higher module costs }\end{array}$ & $\begin{array}{l}\text { - Higher labor wages } \\
\text { - Higher steel prices } \\
\text { - Higher module and } \\
\text { inverter costs }\end{array}$ \\
\hline
\end{tabular}

Hardware costs remained relatively flat, year-on-year, in Q1 2020, as shown in Figure ES-1, resulting in no change to the percentage of non-hardware, or "soft," costs. ${ }^{2}$ Figure ES-2 shows the contribution of soft costs to total costs over time. ${ }^{3}$ Also, soft costs and hardware costs interact. For instance, module efficiency improvements have reduced the number of modules required to construct a system of a given size, thus reducing hardware costs. This trend has also reduced soft costs from direct labor and related installation overhead.

\footnotetext{
${ }^{2}$ Soft cost $=$ total cost - hardware (module, inverter, structural and electrical BOS) cost.

${ }^{3}$ A stagnant or rising soft cost proportion in the last two years in Figure ES-2 indicates soft costs declined more slowly than did hardware costs; it does not indicate soft costs increased on an absolute basis. Historical contributions of soft costs to total utility-scale PV costs differ in this figure from previous versions, because values in previous figures were representative of fixed-tilt systems, whereas these values are representative of a one-axis tracking system.
} 


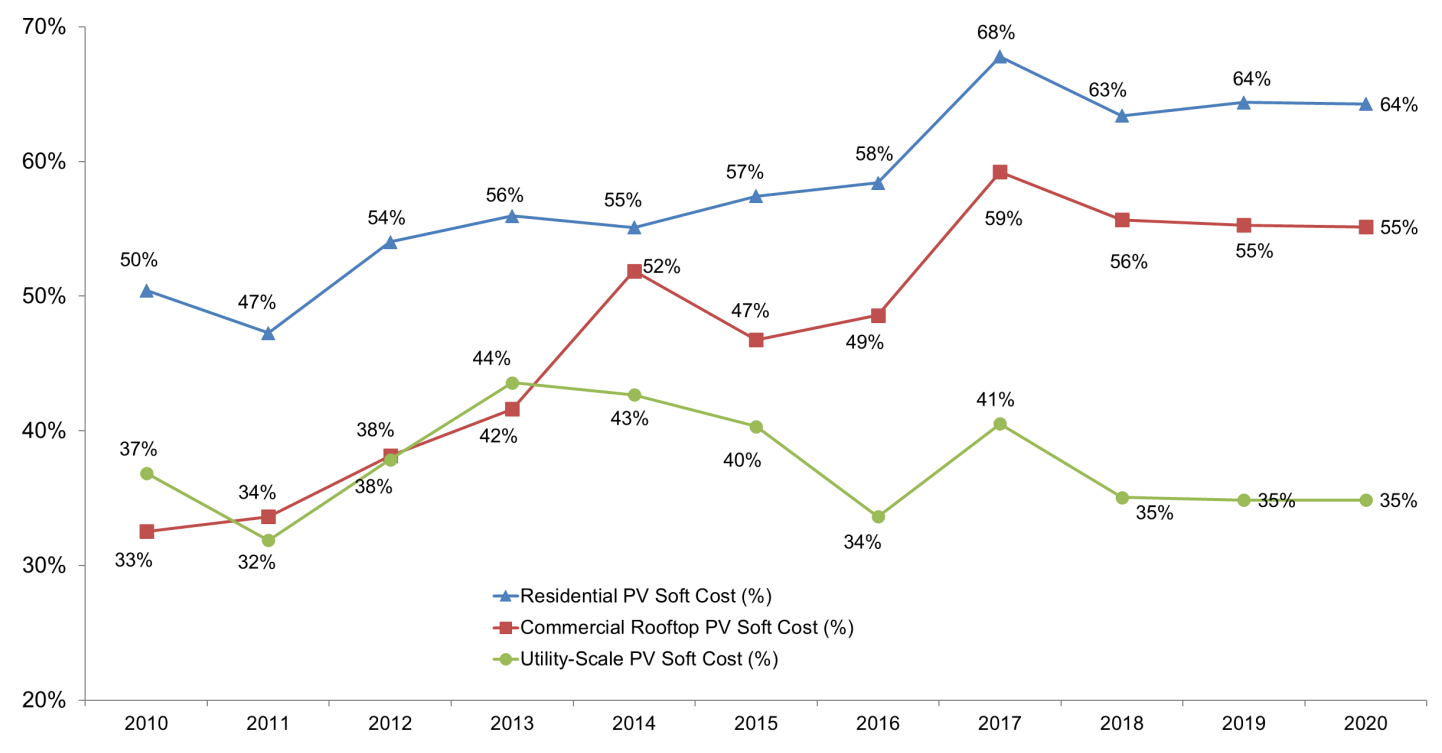

Figure ES-2. Modeled trend of soft cost as a proportion of total cost by sector, 2010-2020

Our bottom-up system cost models enable us to investigate regional variations, system configurations (e.g., module-level power electronics [MLPE] versus non-MLPE, fixed-tilt versus one-axis tracking, and small versus large system size), and business structures (e.g., small installer versus national integrator, and EPC versus developer). Different scenarios result in different costs, so consistent comparisons can only be made when cost scenarios are aligned. The data in this annual benchmark report inform the formulation of and track progress toward the U.S. Department of Energy Solar Energy Technologies Office's (SETO's) Government Performance and Reporting Act cost targets.

The changes in installed cost - along with improvements in operation, system design, and technology - have resulted in changes in the cost of electricity (Figure ES-3). Compared with system prices when SETO's levelized cost of energy (LCOE) targets were announced in 2010, U.S. residential and commercial PV systems are $93 \%$ and $97 \%$ toward achieving the 2020 targets, respectively, and U.S. utility-scale PV systems achieved their 2020 SETO target three years early. In recognition of both the transformative solar progress to date and the potential for additional innovation, SETO extended its goals in 2016 to reduce the unsubsidized LCOE by 2030 to $3 \notin / \mathrm{kWh}$ (utility-scale PV), 4ф/kWh (commercial PV), and $5 ф / \mathrm{kWh}$ (residential PV). Continued research and development, public and private partnerships, and business innovations are necessary to achieve SETO's 2030 LCOE targets. 


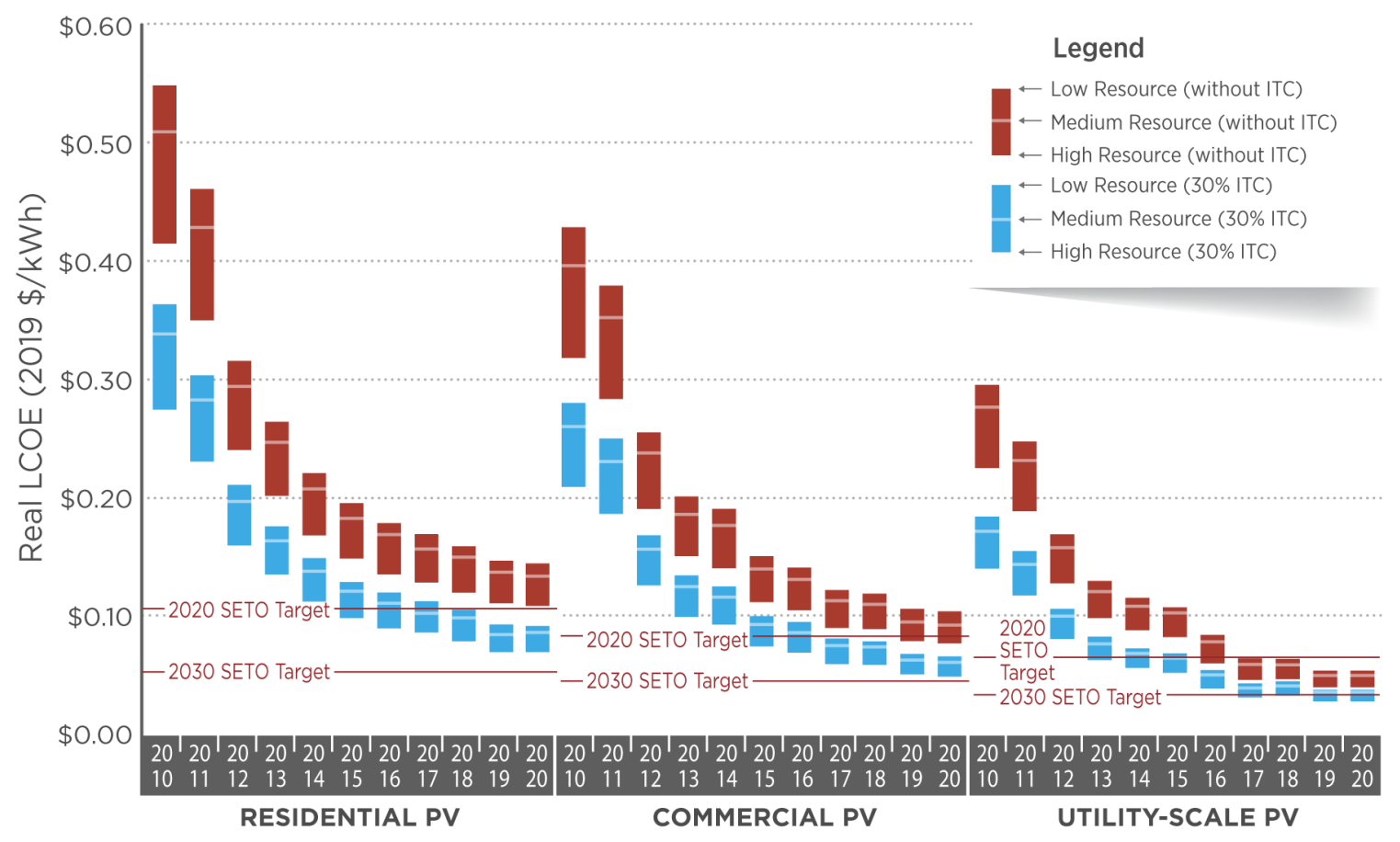

Figure ES-3. NREL PV LCOE benchmark summary (inflation-adjusted), 2010-2020

We updated our methods and model structure in this year's version; 2019 and 2020 LCOEs are higher than they would have been using previous models. Appendix A provides a detailed discussion of the changes made to the models between the previous versions (Fu, Feldman, and Margolis 2018) and this year's versions. LCOE is calculated for each scenario under a range of capacity factors, but all other values remain the same. ${ }^{4}$ ITC $=$ federal investment tax credit.

We also conducted a cost analysis of PV-plus-storage systems. Figures ES-4 and ES-5 put our Q1 2020 PV-plus-storage benchmark results in context with the results of previous NREL benchmarking analyses. Figure ES-4 shows 9\% and 8\% reductions in utility-scale PV-plusstorage benchmarks between 2018 and 2020 for DC-coupled and AC-coupled systems, respectively. Approximately $28 \%-30 \%$ of total cost reductions can be attributed to lithium-ion battery and bidirectional inverter cost reductions. Although there are some configuration differences between AC-coupled and DC-coupled systems (e.g., the inverter, structural BOS, and electrical BOS), the total cost difference between them is only $1 \%$. For an actual project, cost savings may not be the only factor in choosing between DC- or AC-coupling. Additional factors - such as retrofit considerations, system performance (including energy loss due to clipping), design flexibility, and operation and maintenance — should be considered.

\footnotetext{
${ }^{4}$ Capacity factors were calculated using the locations: Phoenix, AZ (high solar resource); Kansas City, MO (medium solar resource); and New York City, NY (low solar resource).
} 


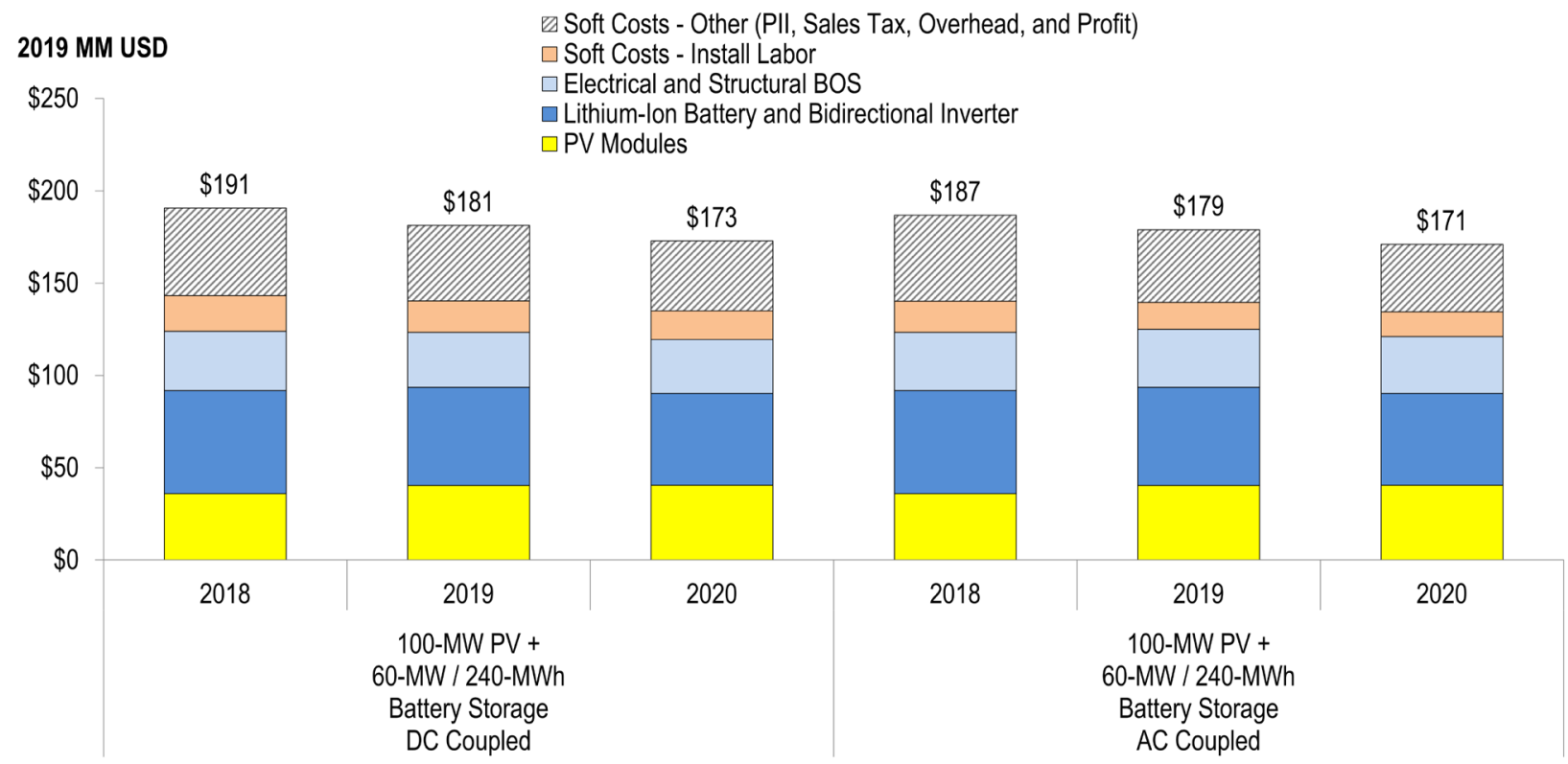

Figure ES-4. Utility-scale PV-plus-storage system cost benchmark summary (inflation-adjusted), 2018-2020, DC-coupled and AC-coupled

The Q1 2018 utility-scale PV-plus-storage benchmark (Fu, Remo, and Margolis 2018) was calculated at a different time than the Q1 2018 utility-scale PV benchmark (Fu, Feldman, and Margolis 2018) and includes different assumptions for PV system costs, including PV module costs. MM = million.

Figure ES-5 shows the $11 \%$ and 25\% reductions in residential PV-plus-storage benchmarks between 2016 and 2020 for AC-coupled less-resilient and more-resilient cases, respectively. Most of these reductions can be attributed to reductions in the cost of PV modules and ACcoupled batteries. The cost reductions occurred despite the rated capacity of the 22-module system increasing from $5.6 \mathrm{~kW}$ to $7.0 \mathrm{~kW}$ between 2016 and 2020.

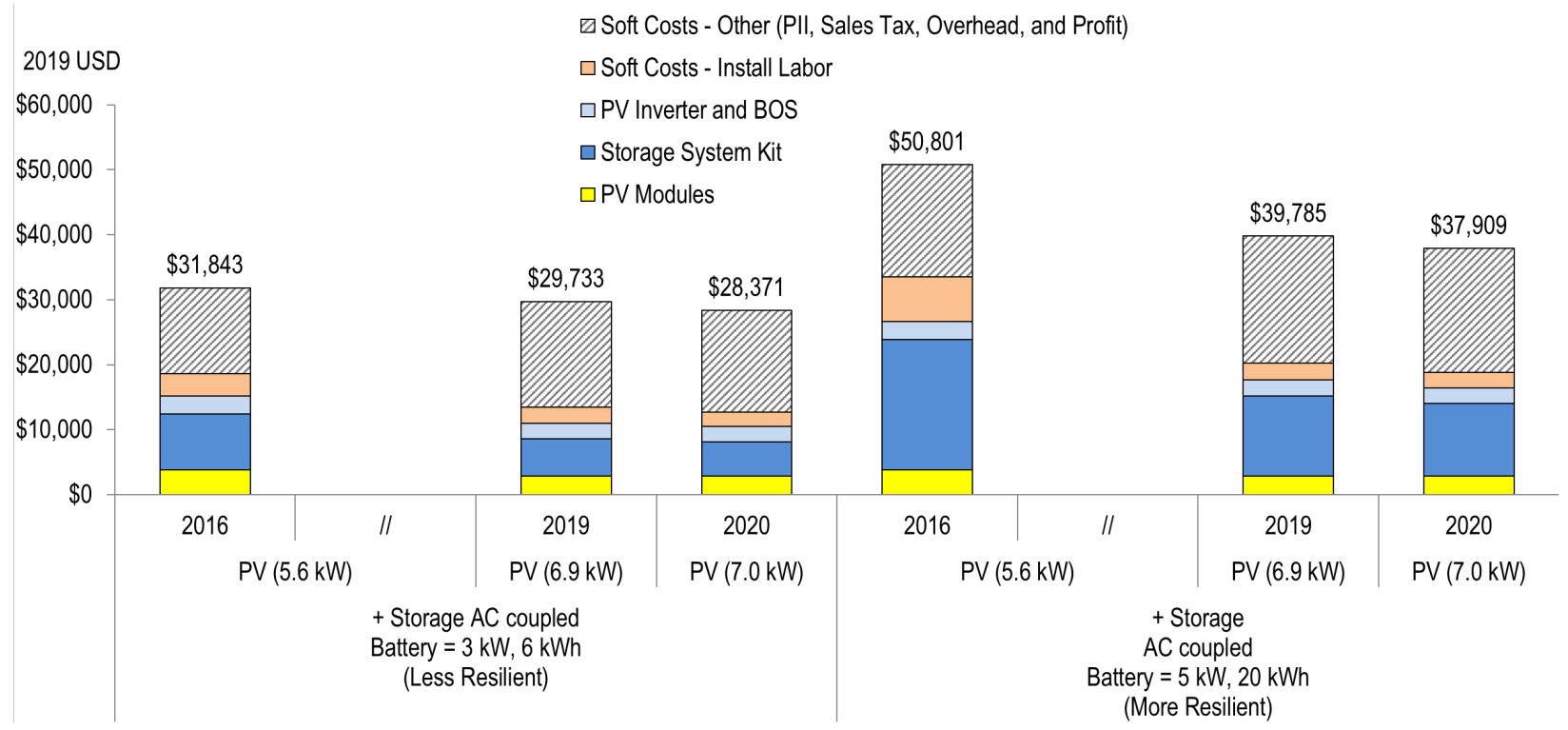

Figure ES-5. Residential PV-plus-storage system cost benchmark summary (inflation-adjusted), 2016, 2019, and 2020 
Finally, for this year's benchmark report, we derive a formula for the levelized cost of solar-plusstorage (LCOSS) to better demonstrate the total cost of operating a PV-plus-storage plant, on a per-MWh basis. Figure ES-6 shows the resulting LCOSS for a colocated AC-coupled PV-plusstorage systems for each market segment, as well as the LCOE of standalone PV systems. For residential PV-plus-storage, LCOSS is calculated to be \$201/MWh without the federal ITC and $\$ 124 / \mathrm{MWh}$ with the 30\% ITC. For commercial PV-plus-storage, it is $\$ 113 / \mathrm{MWh}$ without the ITC and $\$ 73 / \mathrm{MWh}$ with the 30\% ITC. For utility-scale PV-plus-storage, it is $\$ 83 / \mathrm{MWh}$ without the ITC and \$57/MWh with the 30\% ITC. ${ }^{5}$

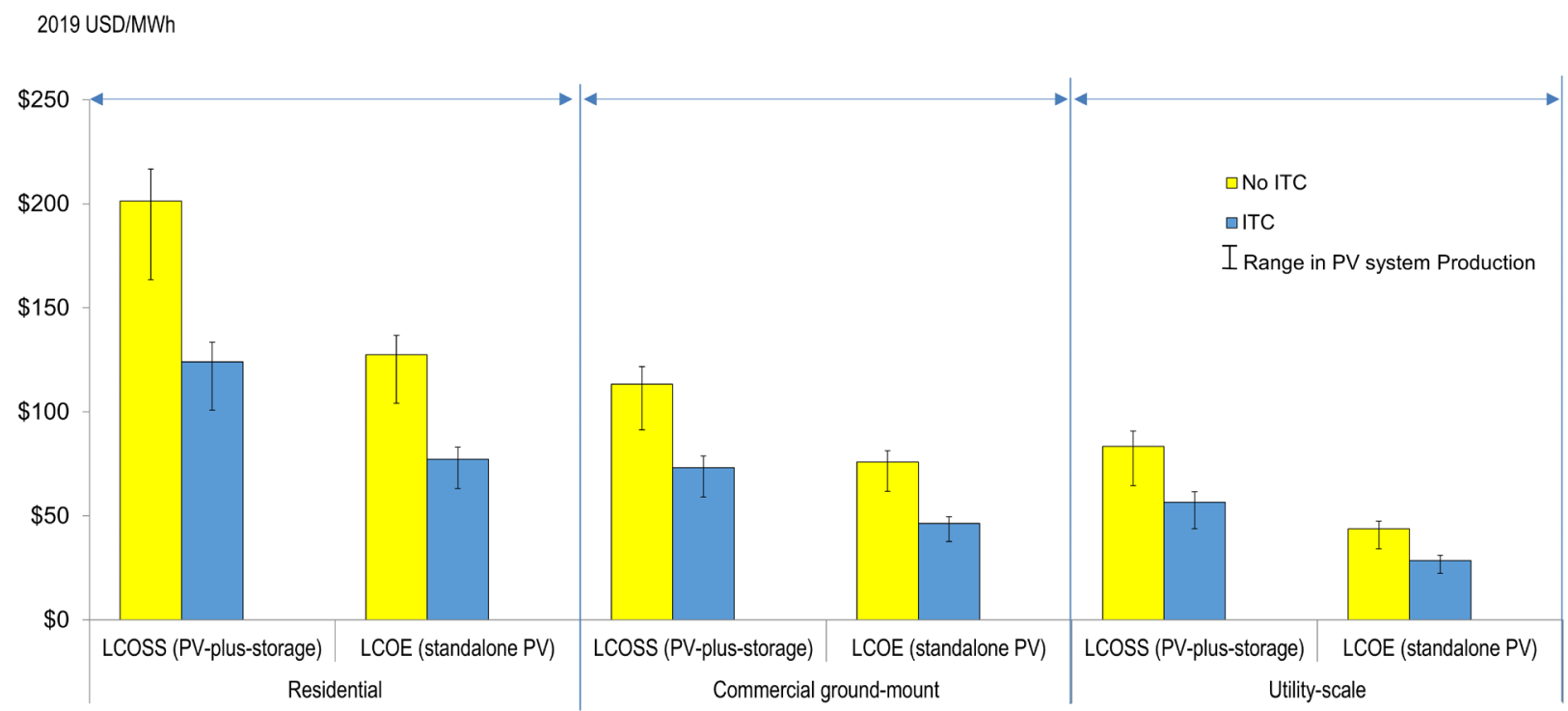

Figure ES-6. LCOSS for AC-coupled PV-plus-storage systems and LCOE for PV standalone systems, by market segment, Q1 2020

LCOSS and LCOE are calculated for each scenario under a medium resource location. The LCOSS and LCOE ranges are based on high and low capacity factor assumptions; all other values remain the same.

\footnotetext{
${ }^{5}$ We use the same inputs and assumptions for the ITC and non-ITC cases, despite the fact that the inputs in the LCOSS calculation assume the owner of the PV-plus-storage system operates the plant so they can claim the ITC on the storage equipment. In reality, an owner would likely operate a PV-plus-storage system differently without the ITC. Additionally, we assume projects can qualify as starting construction before 2020, allowing them to claim a $30 \%$ ITC, instead of the $26 \%$ ITC for projects starting construction in 2020.
} 


\section{Table of Contents}

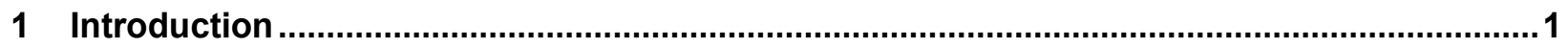

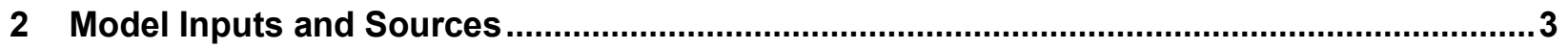

$2.1 \quad$ Tracking the Sun Data Set......................................................................................................... 3

$2.2 \quad$ Module Efficiency ...........................................................................................................

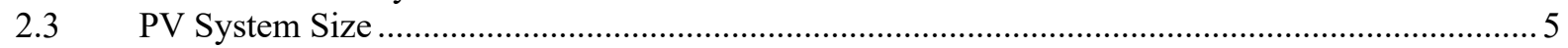

$2.4 \quad$ Module-Level Power Electronics ................................................................................................ 6

2.5 Small Installers versus National Integrators in the Residential PV Model........................................ 8

$2.6 \quad$ Inverter Prices and DC-to-AC Ratios....................................................................................

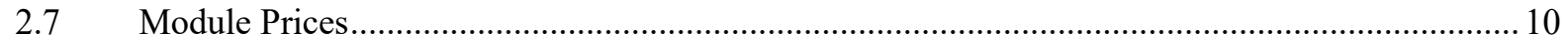

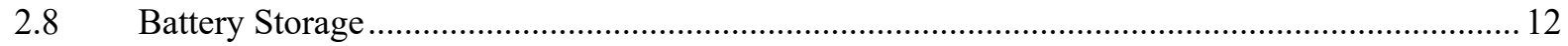

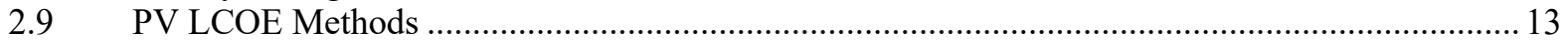

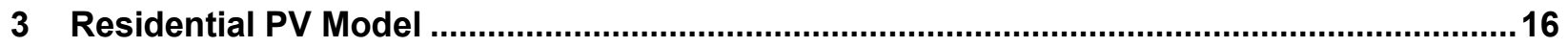

3.1 Residential Model Structure, Inputs, and Assumptions ............................................................ 16

3.2 Expanded "Other Soft Costs" Modeling …………………………………………………..... 18

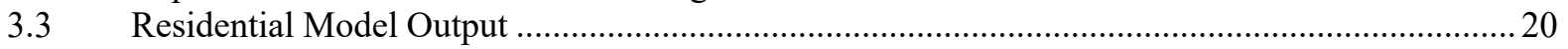

3.4 Residential Model Output versus Reported Costs.......................................................................22

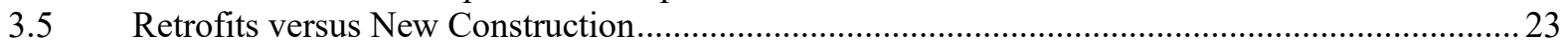

3.6 Additional Costs Typical of Residential PV Installation...........................................................2. 24

3.7 Residential PV Price Benchmark Historical Trends..................................................................2.

3.8 Residential PV LCOE Historical Trends..............................................................................2

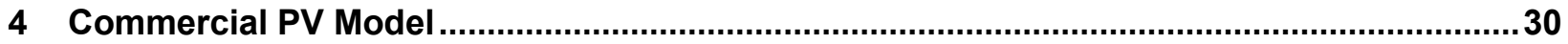

$4.1 \quad$ Commercial Model Structure, Inputs, and Assumptions............................................................. 30

4.2 Commercial Model Output...................................................................................................... 33

4.3 Commercial Rooftop PV Price Benchmark Historical Trends..........................................................37

$4.4 \quad$ Commercial PV LCOE Historical Trends ..................................................................................... 38

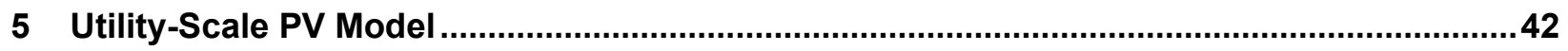

$5.1 \quad$ Utility-Scale Model Structure, Inputs, and Assumptions ............................................................4 42

$5.2 \quad$ Utility-Scale Model Output ....……………………………………………………………4

5.3 Utility-Scale PV Price Benchmark Historical Trends ................................................................ 46

$5.4 \quad$ Utility-Scale PV LCOE Historical Trends ……………………………………………….....4

6 Residential Storage and PV-plus-Storage Model......................................................52

6.1 Residential Li-Ion Standalone Storage Cost Model ………………………………………….....5 53

6.2 Residential PV-plus-Storage System Cost Model ........................................................................5

6.3 Residential Model Output ................................................................................................56

6.4 Residential PV-plus-Storage Price Benchmark Historical Trends ...............................................5

6.5 Residential Levelized Cost of Solar-plus-Storage..........................................................................5

7 Commercial Storage and PV-plus-Storage Model ............................................................62

7.1 Commercial Li-Ion Standalone Storage Cost Model....................................................................62 62

7.2 Commercial PV-plus-Storage System Cost Model ……………………………………………....6 67

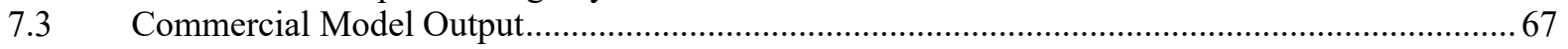

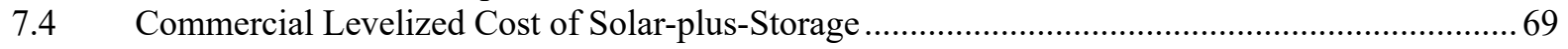

8 Utility-Scale Storage and PV-plus-Storage Model .......................................................

$8.1 \quad$ Utility-Scale Li-Ion Standalone Storage Cost Model................................................................ 72

8.2 Utility-Scale PV-plus-Storage System Cost Model....................................................................... 77

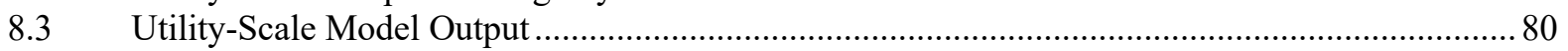

8.4 Utility-Scale PV-plus-Storage Price Benchmark Historical Trends............................................... 82

8.5 Utility-Scale Levelized Cost of Solar-plus-Storage …………………………………………..... 83

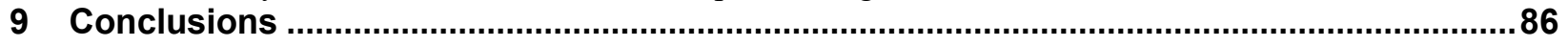

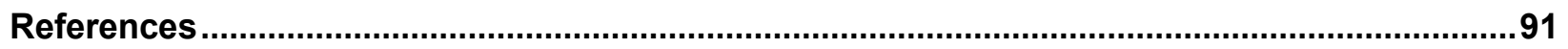

Appendix A. Changes in Methodology Between Q1 2018 and Q1 2020 Reports........................96

Appendix B. PV System LCOE Benchmarks in 2019 USD ...................................................102 


\section{List of Figures}

Figure ES-1. NREL PV system cost benchmark summary (inflation-adjusted), 2010-2020 ............. vii

Figure ES-2. Modeled trend of soft cost as a proportion of total cost by sector, 2010-2020 .............. ix

Figure ES-3. NREL PV LCOE benchmark summary (inflation-adjusted), 2010-2020 .....................

Figure ES-4. Utility-scale PV-plus-storage system cost benchmark summary (inflation-adjusted),

2018-2020, DC-coupled and AC-coupled ……................................................................

Figure ES-5. Residential PV-plus-storage system cost benchmark summary (inflation-adjusted), 2016, 2019, and 2020 .

Figure ES-6. LCOSS for AC-coupled PV-plus-storage systems and LCOE for PV standalone systems, by market segment, Q1 2020 ...........................................................................................

Figure 1. Capacity-weighted average module efficiency trends from the Tracking the Sun (LBNL)

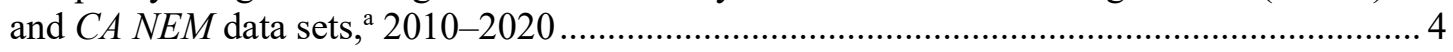

Figure 2. CA NEM and Tracking the Sun PV Installations by Technology, 2010-Q1 2020............... 5

Figure 3. Median PV system size trends from the Tracking the Sun data set, ${ }^{\mathrm{a}} 2010-2018$................. 6

Figure 4. U.S. residential and commercial inverter market from the Tracking the Sun data set, ${ }^{a}$

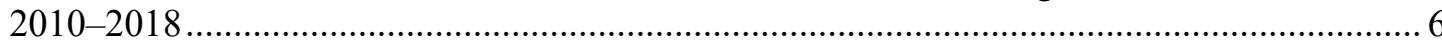

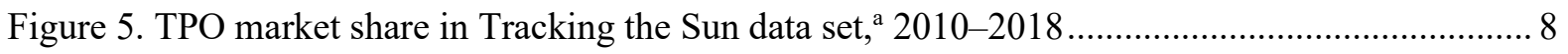

Figure 6. Inverter prices from Wood Mackenzie, 2010-2020 ............................................... 9

Figure 7. Ex-factory gate prices (spot prices) for U.S. and global multicrystalline and monocrystalline

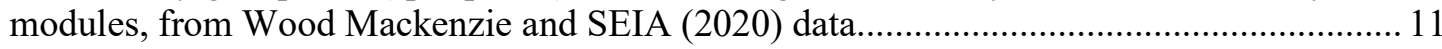

Figure 8. Total residential PV module market costs (2019 USD) .................................................. 12

Figure 9. Ex-factory gate prices (spot prices) for Li-ion batteries by product, from BNEF (2018,

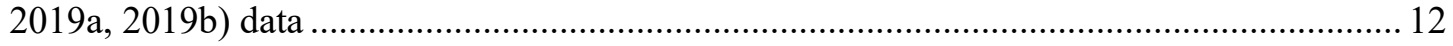

Figure 10. Q1 2020 residential, commercial, and utility-scale O\&M costs by category.................... 14

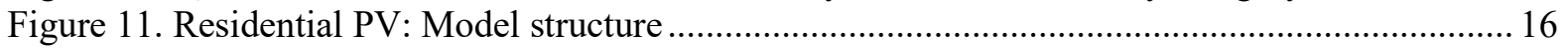

Figure 12. Q1 2020 U.S. benchmark: 7.0-kW residential PV system cost (2019 USD/W

Figure 13. Sensitivity analysis for the Q1 2020 benchmark: Mixed 7.0-kW residential system cost

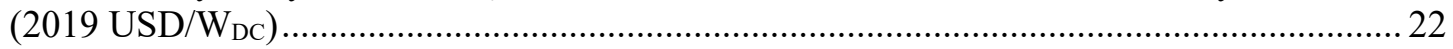

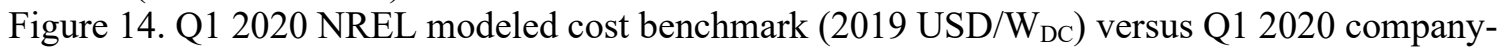

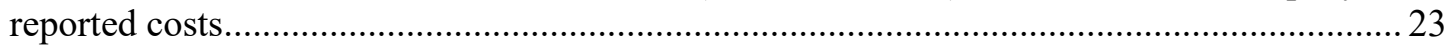

Figure 15. Q1 2020 NREL residential PV modeled cost benchmark (retrofit) versus

Q1 2020 NREL residential PV modeled cost benchmark (new construction) ......................... 24

Figure 16. Standard residential PV installation costs versus cost for systems with necessary additions

Figure 17. NREL residential PV system cost benchmark summary (inflation adjusted), 2010-2020

Figure 18. Q1 2019 cost for a residential multicrystalline PV system and Q1 2019 and Q1 2020

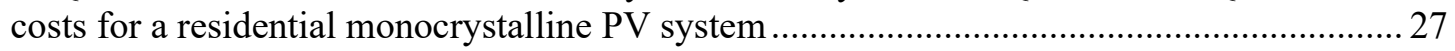

Figure 19. LCOE for residential PV systems, by region, with and without ITC, 2010-2020_........... 29

Figure 20. Commercial PV: Model structure .......................................................................... 31

Figure 21. Q1 2020 U.S. benchmark: Commercial rooftop PV system cost (2019 USD/W

Figure 22. Q1 2020 U.S. benchmark: Commercial ground-mount PV system cost (2019 USD/W 35

Figure 23. Sensitivity analysis for the Q1 2020 benchmark: 200-kW rooftop commercial PV

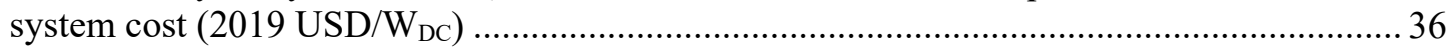

Figure 24. Sensitivity analysis for the Q1 2020 benchmark: 500-kW commercial ground-mount PV system cost (2019 USD/W

Figure 25. NREL commercial rooftop PV system cost benchmark summary (inflation-adjusted), 2010-2020 37

Figure 26. Q1 2019 cost for a commercial rooftop multicrystalline PV system and Q1 2019 and Q1 2020 costs for a commercial rooftop monocrystalline PV system 38 
Figure 27. LCOE for commercial rooftop PV systems, by region, with and without ITC, 2010-2020.

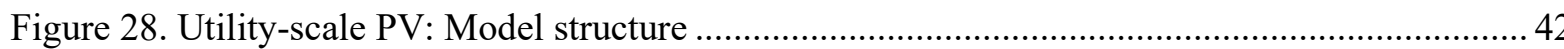

Figure 29. Percentage of U.S. utility-scale PV systems using tracking systems, 2010-2019 ............. 44

Figure 30. Q1 2020 U.S. benchmark: Utility-scale PV total cost (EPC + developer), $2019 \mathrm{USD} / \mathrm{W}_{\mathrm{DC}}$

Figure 31. Sensitivity analysis for the Q1 2020 benchmark: 100-MW one-axis utility-scale PV system cost (2019 USD/W $\mathrm{WC}_{\mathrm{DC}}$ )

Figure 32. NREL utility-scale PV system cost benchmark summary (inflation-adjusted), 2010-2020 46

Figure 33. Q1 2019 costs for utility-scale multicrystalline PV systems and Q1 2019 and Q1 2020 costs for utility-scale monocrystalline PV systems

Table 8. One-Axis Tracker and Fixed-Tilt Utility-Scale PV: LCOE Assumptions, 2010-2020 (2019 USD/W $\left.\mathrm{W}_{\mathrm{DC}}\right)$

Figure 34. LCOE for utility-scale PV systems, by region, with and without ITC, 2010-2020 (fixed-tilt from 2010 to 2015, one-axis tracking from 2016 to 2020) …................................51

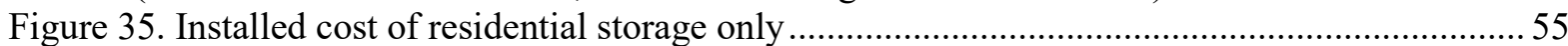

Figure 36. Modeled DC- and AC-coupled system configurations …….......................................... 56

Figure 37. Modeled total installed cost and price components for residential PV-plus-storage systems, less-resilient versus more-resilient battery case (2019 USD) .............................................. 57

Figure 38. Residential PV-plus-storage system cost benchmark summary, 2016, 2019, and $2020 \ldots 58$

Figure 39. U.S. residential LCOSS for an AC-coupled PV $(7 \mathrm{~kW})$ plus storage $(3 \mathrm{~kW} / 6 \mathrm{kWh}$, 2-hour duration) system and LCOE for a 7-kW standalone PV system, Q1 2020 ....................61

Figure 40. Traditional commercial and utility-scale Li-ion battery energy storage components ......... 62

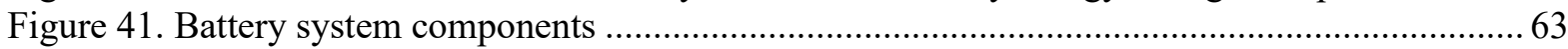

Figure 42. U.S. commercial Li-ion battery standalone storage costs for durations of $0.5-4.0$ hours

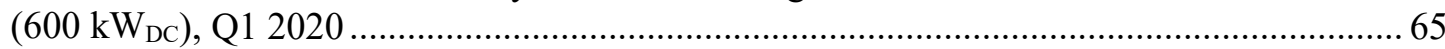

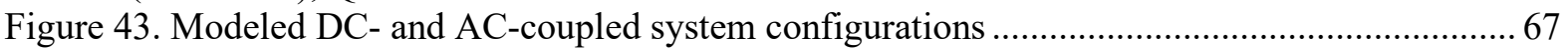

Figure 44. Cost benchmarks for commercial PV-plus-storage systems (4-hour duration) in different

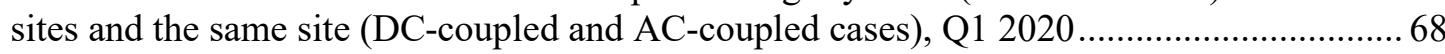

Figure 45. U.S. commercial LCOSS for an AC-coupled PV (1 MW) plus storage (600 kW/2.4 MWh, 4-hour duration) system and LCOE for a 1-MW standalone PV system, Q1 $2020 \ldots .71$

Figure 46. Structure of the bottom-up cost model for utility-scale standalone storage systems .......... 72

Figure 47. U.S. utility-scale Li-ion battery standalone storage costs for durations of $0.5-4.0$ hours

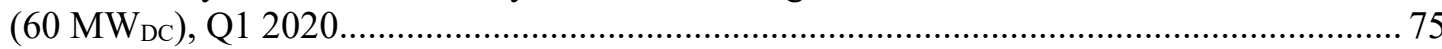

Figure 48. DC-coupled and AC-coupled PV-plus-storage system configurations ............................. 78

Figure 49. Cost benchmarks for PV-plus-storage systems (4-hour duration) in different sites and the same site (DC-coupled and AC-coupled cases), Q1 2020 ............................................ 81

Figure 50. Utility-scale PV-plus-storage system cost benchmark summary 2018-2020, DC-coupled and AC-coupled

Figure 51. U.S. utility-scale LCOSS for an AC-coupled PV (100 MW) plus storage (60 MW/240 MWh, 4-hour duration) system and LCOE for a 100-MW PV standalone system, Q1 2020.85

Figure 52. NREL PV system cost benchmark summary (inflation-adjusted), 2010-2020 ................ 88

Figure 53. Modeled trend of soft cost as a proportion of total cost by sector, 2010-2020 ................ 89

Figure 54. NREL PV LCOE benchmark summary (inflation-adjusted), 2010-2020 90 


\section{List of Tables}

Table ES-1. Benchmark Assumptions.................................................................................................. iv

Table ES-2. Comparison of Q1 2019 and Q1 2020 PV System Cost Benchmarks............................viii

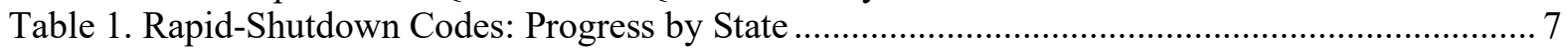

Table 2. Q1 2020 Inverter Price Conversion (2019 USD) .............................................................. 10

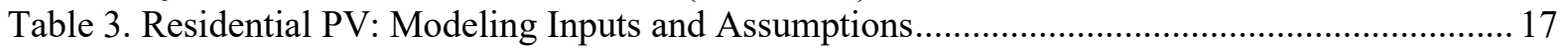

Table 4. Residential PV: LCOE Assumptions, 2010-2020 (2019 USD/W $W_{\text {DC }}$ )................................ 28

Table 5. Commercial PV: Modeling Inputs and Assumptions ................................................... 31

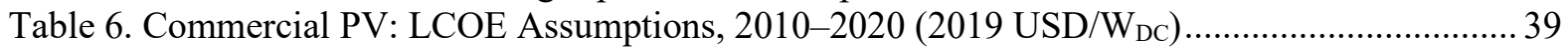

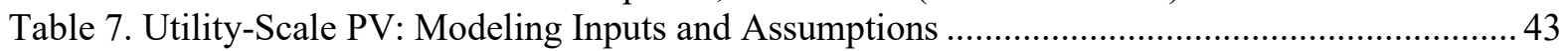

Table 9. Residential Storage-Only Modeling Inputs and Assumptions ............................................ 53

Table 10. Changes to Residential PV and Storage Models When PV and Storage Are Combined ..... 56

Table 11. Residential LCOSS Inputs and Assumptions .................................................................. 59

Table 12. Commercial Li-ion Energy Storage System: Model Inputs and Assumptions..................... 63

Table 13. Detailed Cost Breakdown for a 600-kW U.S. Commercial Li-ion Standalone Storage

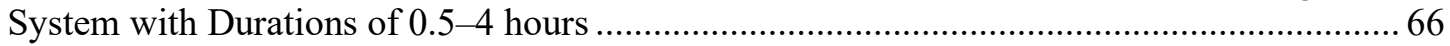

Table 14. Changes to Commercial PV and Storage Models When PV and Storage Are Combined ... 67

Table 15. Detailed Cost Breakdown for Commercial Li-ion PV-Plus-Storage Systems .................... 69

Table 16. Commercial LCOSS Inputs and Assumptions ….............................................................. 70

Table 17. Utility-Scale Li-ion Energy Storage System: Model Inputs and Assumptions ................... 73

Table 18. Detailed Cost Breakdown for a 60-MW U.S. Utility-Scale Li-ion Standalone Storage

System with Durations of 0.5-4 hours ................................................................................ 76

Table 19. Cost Factors for Siting PV and Storage Together versus Separately ................................ 77

Table 20. Comparison of DC- and AC-Coupling for Utility-Scale PV-plus-Storage Systems ............ 79

Table 21. Detailed Cost Breakdown for Utility-Scale Li-ion PV-plus-Storage Systems .................... 82

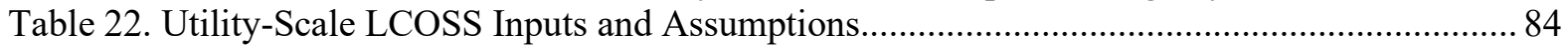

Table 23. Comparison of Q1 2019 and Q1 2020 PV System Cost Benchmarks................................ 89

Table A-1. Comparison of Input Assumptions and Sources in the Q1 2018 Benchmark Report and the Q1 2020 Benchmark Report ...................................................................................... 96

Table A-2. Comparison of Methods for Calculating Q1 2018 Residential PV Soft Costs in the Q1 2018 Benchmark Report and the Q1 2020 Benchmark Report .............................................. 98

Table A-3. Comparison of Q1 2020 Benchmark Costs, per Category, Calculated Using Previous Report's Model (Q1 2018) and the Current Model (Q1 2020) in 2019 USD....................... 101

Table B-1. NREL LCOE Summary $(2019$ cents/kWh) ............................................................... 102 


\section{Introduction}

This report continues previous tracking of photovoltaic (PV) cost reductions by benchmarking the costs of U.S. residential, commercial, and utility-scale PV, energy storage, and PV-plusstorage systems built in the first quarter (Q1) of $2020 .^{6}$ It was produced in conjunction with several related research activities at the National Renewable Energy Laboratory (NREL) and Lawrence Berkeley National Laboratory (LBNL), which are documented by Barbose and Darghouth (2019), Bolinger, Seel, and Robson (2019), ${ }^{7}$ Chung et al. (2015), Feldman et al. (2015), and Fu et al. (2016).

Our benchmarking method includes bottom-up accounting for all necessary system and projectdevelopment costs incurred when installing residential, commercial, and utility-scale systems, and it models the Q1 2019 and Q1 2020 costs for such systems excluding any previous supply agreements or contracts. In general, we attempt to model the typical installation techniques and business operations from an installed-cost perspective, and our benchmarks are national averages. The residential PV-only benchmark and the commercial rooftop PV-only benchmark average costs by inverter type (string inverters, string inverters with direct current [DC] optimizers, and microinverters), weighted by inverter market share. The residential PV-only benchmark is further averaged across small installer and national integrator business models, weighted by market share. All benchmarks include variations - accounting for the differences in size, equipment, and operational use (particularly for storage) - that are currently available in the marketplace. All benchmarks assume nonunionized construction labor; residential and commercial PV systems predominantly use nonunionized labor, and the type of labor required for utility-scale PV systems depends heavily on the development process. All benchmarks assume the use of monofacial monocrystalline silicon PV modules. Benchmarks using cadmium telluride (CdTe) or bifacial modules could result in significantly different results. ${ }^{8}$ The data in this annual benchmark report inform the formulation of and track progress toward the U.S. Department of Energy (DOE) Solar Energy Technologies Office's (SETO's) Government Performance and Reporting Act (GPRA) cost targets.

\footnotetext{
${ }^{6}$ Previous cost benchmark reports include reports published for Q1 $2018 \mathrm{PV} \mathrm{(Fu,} \mathrm{Feldman,} \mathrm{and} \mathrm{Margolis} \mathrm{2018),}$ 2018 PV-plus-storage (Fu, Remo, and Margolis 2018), 2017 PV (Fu et al. 2017), 2016 PV (Fu et al. 2016), and 2015 utility-scale PV (Fu et al. 2015).

${ }^{7}$ LBNL compares the bottom-up cost results of various entities, including our results.

${ }^{8}$ In this report, we focus on the installation costs of crystalline-silicon modules, but a significant portion of U.S. utility-scale PV systems use CdTe modules. From 2010-2019, CdTe accounted for approximately $30 \%$ of U.S. utility-scale PV deployment (EIA 2020). This portion of the market is particularly noticeable given that CdTe modules only represented $4 \%$ of global PV shipments over the same period. Similarly, a growing number of U.S. systems are beginning to use bifacial modules, with transparent backs, which generate electricity from both sides of the module - as opposed to traditional monofacial modules, which typically have opaque backsheets. Because of the relative newness of bifacial modules, we do not have sufficient data on their current U.S. market share.
} 
Our modeled costs can be interpreted as the sales price an engineering, procurement, and construction (EPC) contractor or developer might charge for a system before any developer fee or price gross-up (although our costs do include development costs). We use this approach because of the wide variation in developer profits in all three sectors (residential, commercial, and utility-scale), where project pricing depends highly on region and project specifics such as local retail electricity rate structures, local rebate and incentive structures, competitive environment, and overall project or deal structures.

The current versions of our cost models make a few significant changes from the versions used in our previous Q1 2018 benchmark report (Fu, Feldman, and Margolis 2018). To better attribute the historical cost trends over time from the changes to our cost models, we also calculate Q1 2019 and Q1 2020 PV benchmarks using the Q1 2018 versions of the residential, commercial, and utility-scale PV models. Appendix A provides a detailed discussion of the changes made to this year's models from previous versions (Fu, Feldman, and Margolis 2018).

The remainder of the report is organized as follows. Section 2 describes our model inputs and sources. Sections 3,4 , and 5 show specific model inputs and outputs for residential, commercial, and utility-scale PV-only systems, including historical trends in system costs and the levelized costs of energy. Sections 6, 7, and 8 show specific model inputs and outputs for residential, commercial, and utility-scale PV-plus-storage systems, including a limited set of historical trends in system costs and the levelized cost of PV-plus-storage. Finally, Section 9 puts the results in context and offers conclusions. 


\section{Model Inputs and Sources}

This section describes our model inputs and sources. Section 2.1 describes one of our main data sources for the system characteristics and business models of residential and commercial PV, ${ }^{9}$ the 2019 edition of Tracking the Sun (Barbose and Darghouth 2019). Sections 2.2 through 2.5 detail the inputs from the Tracking the Sun data set that affect PV system cost. Sections 2.6 through 2.8 detail our cost input assumptions for the highest-cost components (inverters, modules, and battery packs), and Section 2.9 describes our levelized cost of energy (LCOE) calculation methods.

\subsection{Tracking the Sun Data Set}

We use data from the 2019 edition of Tracking the Sun (Barbose and Darghouth 2019) to benchmark generic system characteristics, such as module efficiency, system size, and direct- to alternating-current (DC-to-AC) ratio for commercial and residential systems, as well as choice of power electronics and installer type for residential PV standalone systems. Tracking the Sun is based on a data set compiled primarily from state agencies, utilities, and other organizations that administer PV incentive programs, solar renewable energy credit registration systems, or interconnection processes. The full sample, from 30 states, includes most U.S. grid-connected residential and nonresidential PV systems, but it excludes all ground-mounted PV systems larger than $5 \mathrm{MW}_{\mathrm{AC}}$ and therefore excludes U.S. utility-scale PV systems. In total, it consists of more than 1.6 million individual PV systems installed through year-end 2018, including roughly 250,000 systems installed in 2018 . These systems represent $81 \%$ of all U.S. residential and nonresidential systems installed cumulatively through 2017 and $76 \%$ of installations in 2018 . The authors have also taken various steps to clean and standardize the raw data to ensure its accuracy. Because the analysis - and publication — of the Q1 2019 and Q1 2020 modeled benchmarks occur before 2019 and 2020 characteristic data are available, we use 2018 Tracking the Sun values for the market share of inverters and national integrators, and we rely on the California Net Energy Metering (CA NEM) Interconnection data set for module efficiency.

\subsection{Module Efficiency}

Figure 1 displays module efficiency data from the Tracking the Sun data set from 2010 to 2018, along with data from the CA NEM Interconnection data set through Q1 2020. ${ }^{10}$ Since 2010, efficiencies for monocrystalline and multicrystalline modules have steadily improved, with the capacity-weighted average multicrystalline module efficiency, for 60- and 72-cell modules, increasing $0.3 \%-0.4 \%$ each year in absolute terms, on average. CA NEM values line up very

\footnotetext{
${ }^{9}$ To represent commercial PV systems, we apply the characteristics of nonresidential PV systems in the Tracking the Sun data set that are larger than $100 \mathrm{~kW}$ (and smaller than $5 \mathrm{MW}_{\mathrm{AC}}$ for ground-mount systems). In addition to rooftop commercial PV systems, the data set includes ground-mounted commercial PV systems as well as systems for industrial applications, government sites, non-profits, and schools.

${ }^{10}$ We use CA NEM data for the average module efficiency of utility-scale PV systems as well, even though the data set does not include any utility-scale PV systems. We think this is justifiable, because PV modules can be used for either application, and there is no comparable utility-scale PV data set to calculate average module efficiency in that sector. That being said, there may be some discrepancies with real-world data, because significantly more CdTe is deployed in the utility-scale PV sector than in the residential and commercial sectors. Module efficiency values from CA NEM include only 60-cell and 72-cell modules from its data set to better correspond with the pricing data we use. SunPower IBC panels, for example, are more efficient and have a different cell count, but also come at a price premium.
} 
closely with the national averages reported in Tracking the Sun. CA NEM reports a Q1 2020 capacity-weighted average monocrystalline module efficiency of $19.5 \%$. Because module selection may vary by region and sector, the capacity-weighted average module efficiencies (and module prices) may be different in some regions and sectors. ${ }^{11}$

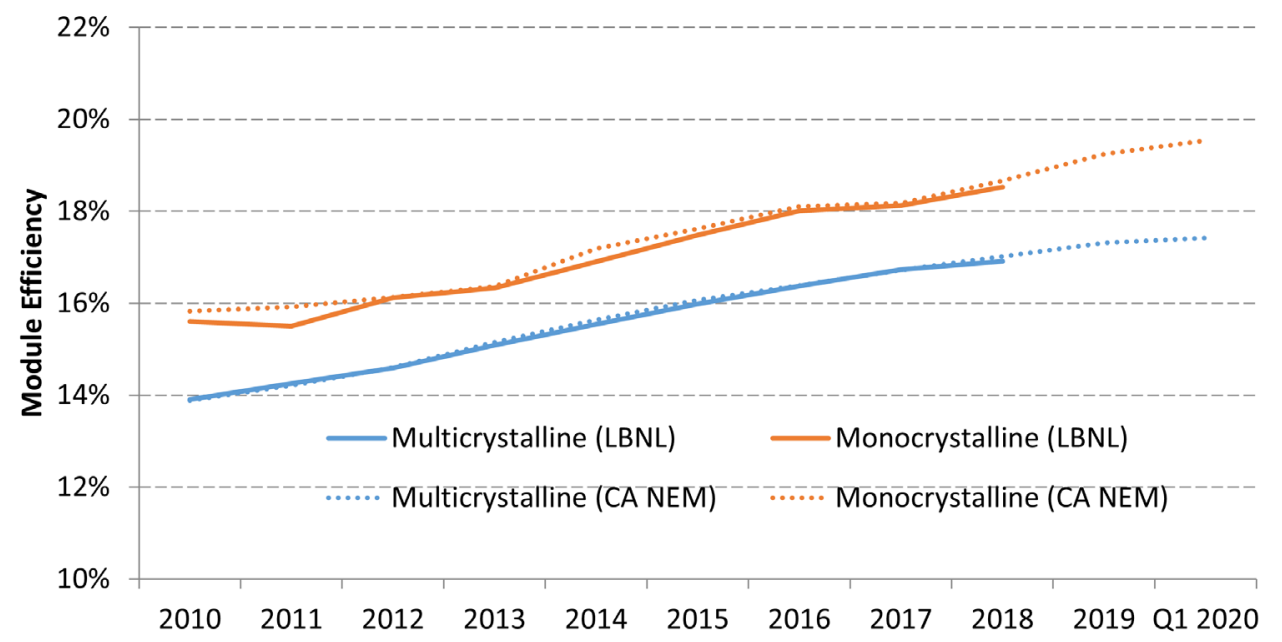

Figure 1. Capacity-weighted average module efficiency trends from the Tracking the Sun (LBNL) and CA NEM data sets, ${ }^{\mathrm{a}}$ 2010-2020

a Barbose and Darghouth (2019), CA NEM (2020)

In this year's report, we model systems using monocrystalline PV modules rather than the multicrystalline modules we modeled previously (Fu, Feldman, and Margolis 2018). When we started benchmarking PV system prices in 2010, most U.S. PV systems used multicrystalline modules. However, there has been an overall shift in the United States to using more monocrystalline modules since 2016. For example, CA NEM reports that multicrystalline's percentage of installed PV systems in California peaked over the decade in 2013-2015 at approximately 70\%, but as of Q1 2020 had shrunk to 16\% (Figure 2). Across the United States, the percentage of distributed PV systems that installed multicrystalline modules dropped from 65\% in 2015 to $11 \%$ in 2018 (Barbose and Darghouth 2019). Much of this shift can be attributed to the rapid manufacturing expansion and associated reduction in price of passivated emitter and rear cells (PERC) monocrystalline technology. Monocrystalline modules sell at a premium over multicrystalline modules, but their higher efficiency can reduce the LCOE of PV systems.

We compare the 2019 total system cost between PV systems using monocrystalline modules and those using multicrystalline modules in residential, commercial rooftop, and utility-scale PV systems in Section 3.7.1, Section 4.3.1, and Section 5.3.1.

\footnotetext{
11 The residential sector has historically used a higher percentage of monocrystalline panels than other sectors.
} 


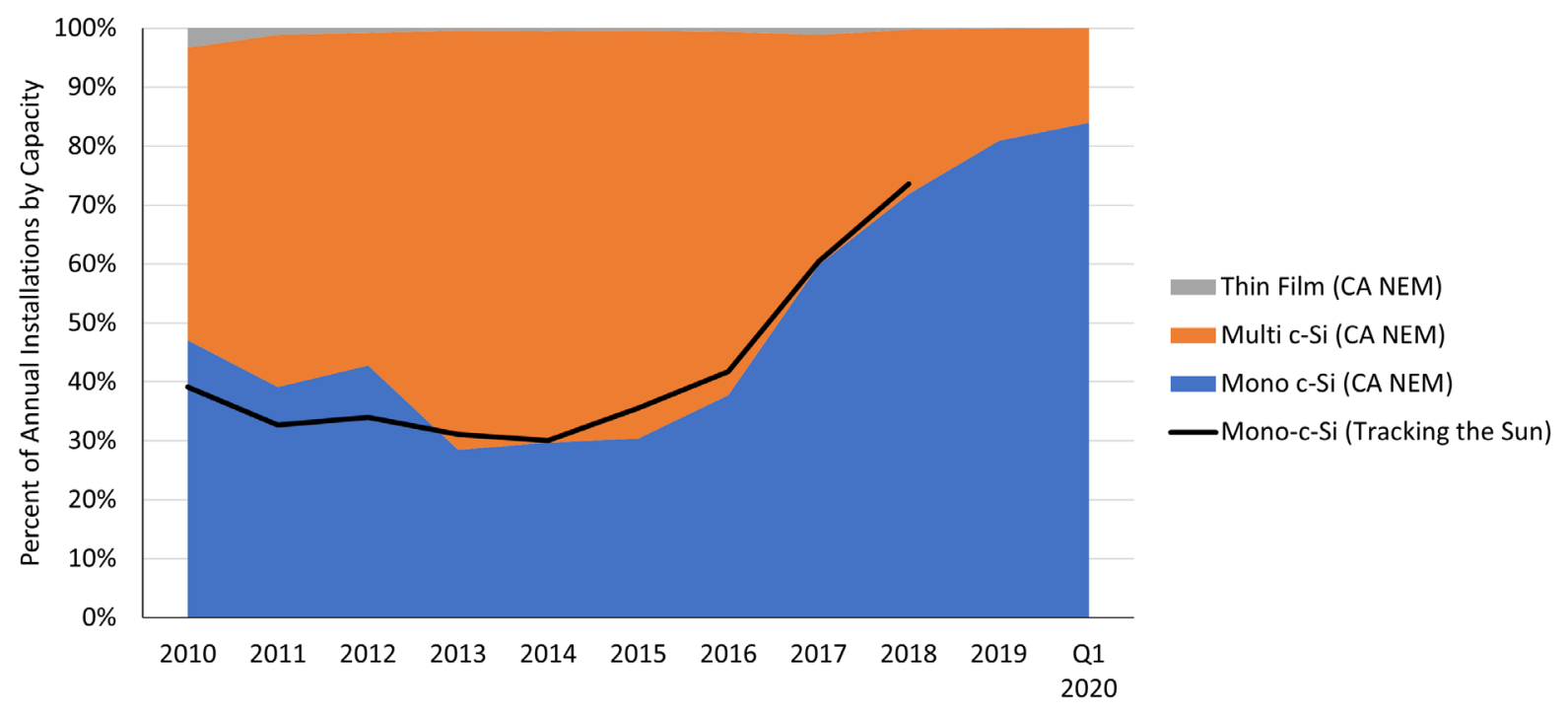

Figure 2. CA NEM and Tracking the Sun PV Installations by Technology, 2010-Q1 2020

Sources: Barbose and Darghouth (2019), CA NEM (2020). c-Si = crystalline silicon.

\subsection{PV System Size}

Figure 3 displays median PV system sizes from the 2019 edition of Tracking the Sun. Residential system sizes steadily increased from 2010 to 2018. As in previous years, we assume a 22-module design for our residential PV system benchmark, which results in a system size of $6.3 \mathrm{~kW}$, based on the assumed 2018 average multicrystalline module efficiency. This is slightly smaller than the 2018 median size of $6.4 \mathrm{~kW}$ from Tracking the Sun; in 2019 and 2020, our residential PV system benchmarks are larger $(6.6 \mathrm{~kW}$ and $7.0 \mathrm{~kW}$, respectively) owing to efficiency improvements over time and the switch in our model to the use of monocrystalline modules. Commercial system sizes have varied more, which likely reflects the wide range of users (e.g., office buildings, malls, and retail stores). Limiting commercial systems to those larger than $100 \mathrm{~kW}$ (the minimum size we model for commercial systems in this report and the vast majority of commercial PV installed capacity each year), the median system size has ranged from $200 \mathrm{~kW}$ to $350 \mathrm{~kW}$ for rooftop systems and $400 \mathrm{~kW}$ to $1,200 \mathrm{~kW}$ for ground-mount applications. We use $200 \mathrm{~kW}$ and $500 \mathrm{~kW}$ as the baseline cases in our commercial rooftop and ground-mount PV models, respectively. 


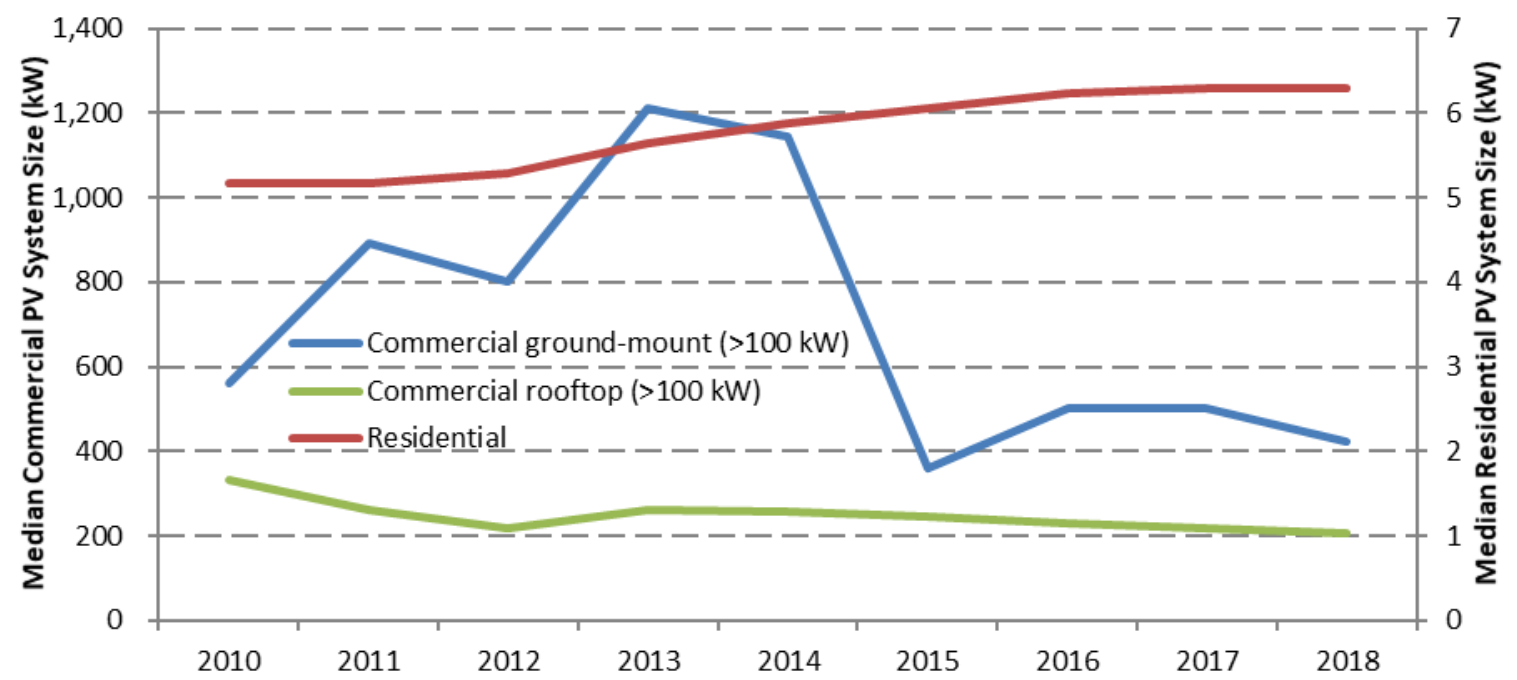

Figure 3. Median PV system size trends from the Tracking the Sun data set, ${ }^{a}$ 2010-2018

a Barbose and Darghouth (2019)

\subsection{Module-Level Power Electronics}

Microinverters and DC power optimizers are collectively referred to as module-level power electronics (MLPE). By allowing designs with different roof configurations (e.g., orientations and tilts), constantly tracking the maximum power point for each module, and providing rapidshutdown at the module level (required in some states), MLPE provide an optimized design solution at the module level. In 2018, MLPE reached $86 \%$ of the total Tracking the Sun residential data set (Figure 4 ).

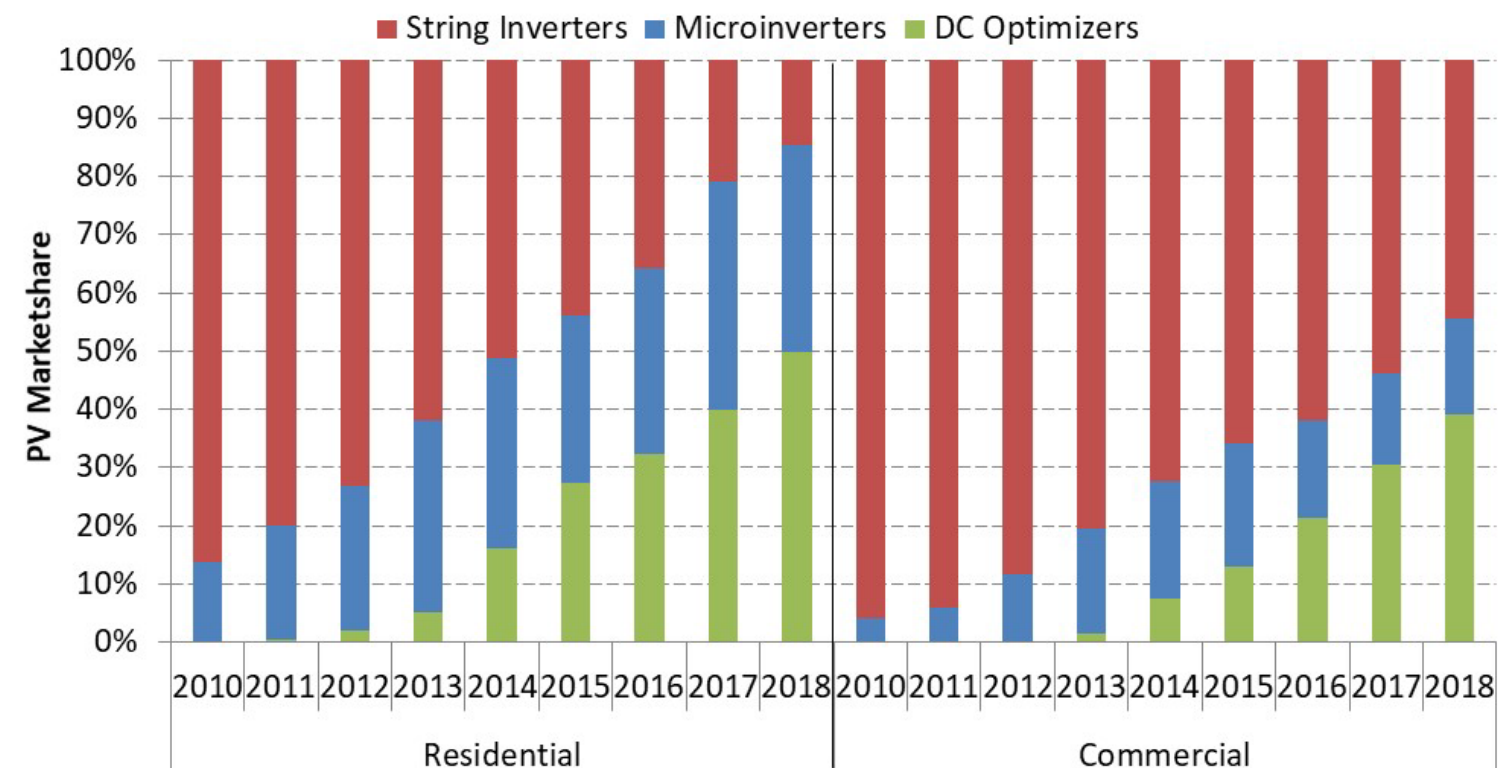

Figure 4. U.S. residential and commercial inverter market from the Tracking the Sun data set, ${ }^{a}$ 2010-2018

a Barbose and Darghouth (2019) 
For residential system costs, we model the string inverter, power optimizer, and microinverter options separately, and we use their market shares $(14.6 \%, 49.8 \%$, and 35.6\%) in our Q1 2020 model for the weighted-average case. MLPE growth has been slower in the commercial rooftop sector, although it has started to accelerate in the past few years, reaching a share of $55 \%$ in 2018. In past years, we only assumed string inverters for the commercial PV benchmark, rather than weighting by MLPE share; this year, we also weight the commercial rooftop PV benchmark by MLPE share (45\% for three-phase string inverters, 39\% for power optimizers, and 16\% for microinverters), because of changes to the National Electrical Code (NEC).

For safety reasons, rapid-shutdown codes were implemented at the array level in the 2014 NEC and at the module level in the 2017 NEC, for rooftop PV systems. Although the 2014 NEC required array-level rapid-shutdown, systems were also required to have the ability to reduce system voltage quickly, so that no wires were energized more than five feet inside a building or 10 feet from a PV module array. Commercial rooftop PV systems accomplished this by having the three-phase string inverters within 10 feet of the PV array to provide the disconnect, but string-level inverters often cannot be located within 10 feet of a residential PV system.

Therefore, residential PV systems either required the installation of an additional combiner box with a single array-level disconnect, or the more popular option: MLPE. Because the 2017 NEC requires rapid shutdown at the module level for rooftop applications, the switch from the 2014 NEC to the 2017 NEC has a larger impact on commercial rooftop PV systems.

As of July 1, 2020, 34 states and Puerto Rico had adopted the 2017 or 2020 NEC rapid-shutdown code (with California and South Carolina implementing it in 2020), and 11 states had adopted the 2014 NEC (Table 1).

Table 1. Rapid-Shutdown Codes: Progress by State

\begin{tabular}{|c|c|c|}
\hline Code & $\begin{array}{l}\text { Rapid- } \\
\text { Shutdown }\end{array}$ & State \\
\hline 2020 NEC & $\begin{array}{l}\text { Yes (module- } \\
\text { level) }\end{array}$ & Massachusetts \\
\hline 2017 NEC & $\begin{array}{l}\text { Yes (module- } \\
\text { level) }\end{array}$ & $\begin{array}{l}\text { Alaska, Arkansas, California, Colorado, Connecticut, Georgia, } \\
\text { Hawaii, Idaho, lowa, Kentucky, Maine, Michigan, Minnesota, } \\
\text { Nebraska, Nevada, New Hampshire, New Jersey, New Mexico, } \\
\text { North Carolina, North Dakota, Ohio (commercial), Oregon, Rhode } \\
\text { Island, South Carolina, South Dakota, Tennessee, Texas, Utah, } \\
\text { Vermont, Washington, Wisconsin, Wyoming, West Virginia, and } \\
\text { Puerto Rico }\end{array}$ \\
\hline 2014 NEC & $\begin{array}{l}\text { Yes (array-level, } \\
\text { within } 10 \text { feet) }\end{array}$ & $\begin{array}{l}\text { Alabama, Delaware, Florida, Louisiana, Maryland, Montana, New } \\
\text { York, Ohio (residential), Oklahoma, Pennsylvania, Virginia }\end{array}$ \\
\hline 2011 NEC & No & Washington, D.C. \\
\hline 2008 NEC & No & Indiana \\
\hline $\begin{array}{l}\text { No statewide } \\
\text { NEC adoption }\end{array}$ & No & Arizona, Illinois, Kansas, Mississippi, and Missouri \\
\hline
\end{tabular}

Source: NEMA (2020) 


\subsection{Small Installers versus National Integrators in the Residential PV Model}

Our residential PV benchmark is based on two different business structures: "small installer" and "national integrator." We define small installers as businesses that engage in lead generation, sales, and installation but do not provide financing solutions in-house, although they may partner with a larger company to offer customers loans, leases, or power-purchase agreements (PPAs). National integrators perform all small installer functions, and they directly provide financing and system monitoring for third-party-ownership (TPO) systems. ${ }^{12}$ In our models, the difference between small installers and national integrators is manifested in (1) differences in module and inverter prices that are due to the buying power of national integrators and (2) differences in customer acquisition, permitting, inspection, and interconnection (PII), and overhead cost categories, where national integrators are modeled with higher expenses for customer acquisition (relying less on referrals and spending more time on growing markets) and PII (due to higher cancellation rates). Although national integrators provide financing solutions, we do not incorporate financing costs into the benchmark.

As shown in Figure 5, residential TPO systems have lost market share to the direct business model since 2015 , led by small installers. We use $38 \%$ national integrator and $62 \%$ small installer market shares to compute the national weighted-average case in our Q1 2020 residential PV model.

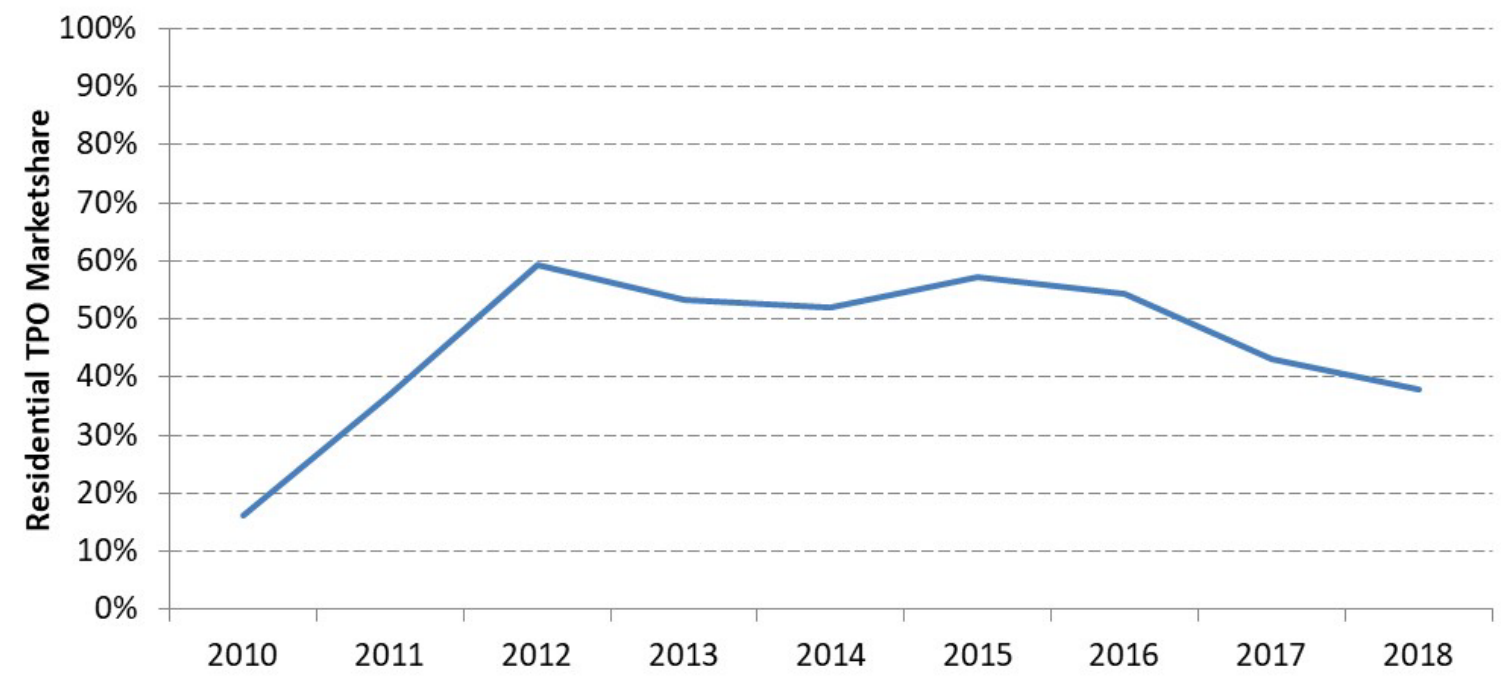

Figure 5. TPO market share in Tracking the Sun data set, ${ }^{\text {a } 2010-2018}$

a Barbose and Darghouth (2019)

\footnotetext{
${ }^{12}$ For modeling purposes, we separate the residential market into small installers and national integrators using TPO market share. In reality, there are a wide range of business models and installer sizes. Most TPO providers are national integrators and offer mostly TPO products. Even small installers that offer financing typically get that financing from a larger, national company, so their costs would be borne by that model as well. In short, it is a simplification, but we think a reasonable one.
} 


\subsection{Inverter Prices and DC-to-AC Ratios}

As shown in Figure 6, we source inverter prices, including MLPE prices, from the Wood Mackenzie (Wood Mackenzie 2020) database, which contains typical U.S. prices from Tier 1 suppliers to developers in the market. For Q1 2020 modeling, we convert the U.S. dollar (USD) per $\mathrm{W}_{\mathrm{AC}}$ inverter prices from Wood Mackenzie (2020) to $2019 \mathrm{USD} / \mathrm{W}_{\mathrm{DC}}$ using the Consumer Price Index (CPI) and the DC-to-AC ratios shown in Table 2. We model systems using an average DC-to-AC ratio, but a wide variety of DC-to-AC ratios are reported for U.S. PV systems.

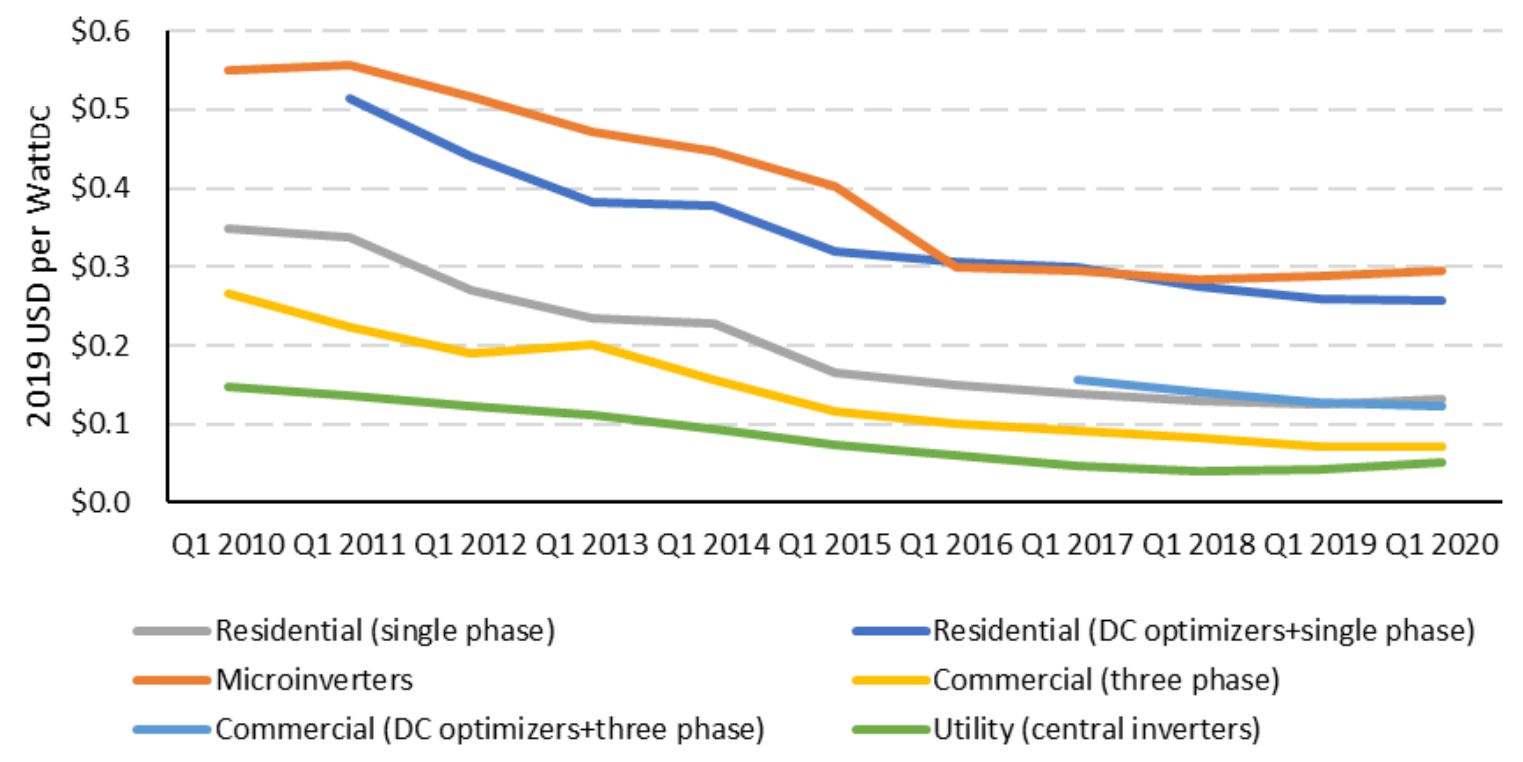

Figure 6. Inverter prices from Wood Mackenzie, 2010-2020

Data are from Wood Mackenzie (2014a, 2014b, 2019a, 2020) and Wood Mackenzie and SEIA (2020). Data are also supplemented, in 2010 and 2011, using revenue per-watt shipped data from Enphase (2019) for microinverters. 
Table 2. Q1 2020 Inverter Price Conversion (2019 USD)

\begin{tabular}{|c|c|c|c|c|}
\hline Inverter Type & Sector & $\mathrm{USD}_{\mathrm{WAC}}$ & DC-to-AC Ratio ${ }^{a}$ & USD/W \\
\hline $\begin{array}{l}\text { Single-phase } \\
\text { string inverter }\end{array}$ & Residential PV (non-MLPE) & 0.15 & 1.11 & 0.14 \\
\hline Microinverter & $\begin{array}{l}\text { Residential and commercial PV } \\
\text { (MLPE) }\end{array}$ & 0.34 & 1.16 & 0.29 \\
\hline $\begin{array}{l}\text { DC power optimizer, } \\
\text { single-phase string } \\
\text { inverter }\end{array}$ & Residential PV (MLPE) & 0.30 & 1.16 & 0.26 \\
\hline $\begin{array}{l}\text { Three-phase } \\
\text { string inverter }\end{array}$ & Commercial PV (non-MLPE) & 0.08 & 1.11 & 0.07 \\
\hline $\begin{array}{l}\text { DC power optimizer, } \\
\text { three-phase string } \\
\text { inverter }\end{array}$ & Commercial PV (MLPE) & 0.14 & 1.16 & 0.12 \\
\hline Central inverter & Utility-scale PV (fixed-tilt) & 0.07 & 1.37 & 0.05 \\
\hline Central inverter & Utility-scale PV (1-axis tracker) & 0.07 & 1.34 & 0.05 \\
\hline
\end{tabular}

All inverter prices include the cost of monitoring equipment.

a We updated the inverter DC-to-AC ratios using LBNL data (Bolinger, Seel, and Robson 2019; Barbose and Darghouth 2019).

\subsection{Module Prices}

We assume an ex-factory gate (spot or first-buyer) price of $\$ 0.41 / \mathrm{W}_{\mathrm{DC}}$ for Tier 1 monocrystalline modules in Q1 2020, based on Wood Mackenzie and SEIA (2020). As Figure 7 shows, U.S. spot prices declined substantially between 2014 and 2016, and they approached global spot prices. In 2017, however, U.S. spot prices rose as global spot prices continued to decline. Several factors, including U.S. policy on imported modules, may have contributed to the divergence between U.S. and global spot prices. In early 2018, U.S. spot prices began to drop again; in Q1 2020, U.S. module prices continued to fall, dropping close to their lowest recorded levels, but monocrystalline modules were still trading at a significant premium over the global module average selling price (ASP). In the past few years, the U.S. market has had such an increasing demand for monocrystalline modules that by 2020 there was not enough demand for multicrystalline modules to give an "apples-to-apples" comparison of U.S. spot pricing in Q1 2020; therefore, when comparing the two technologies, we model Q1 2019 costs. In Q1 2019, we assume an ex-factory gate price of $\$ 0.40 / \mathrm{W}_{\mathrm{DC}}$ for Tier 1 monocrystalline modules and $\$ 0.33 / \mathrm{W}_{\text {DC }}$ for Tier 1 multicrystalline modules, based on Wood Mackenzie and SEIA (2020). 
Although commercial and utility-scale PV developers typically can procure modules at or near the spot price, residential national integrators and small installers incur additional supply chain costs (Figure 8). Historical inventory can create a price lag (approximately six months) for the market module price in the residential sector when the modules from previous procurements are installed in today's systems. In our Q1 2020 residential PV benchmark, this supply chain cost equates to a $\$ 0.02 / \mathrm{W}(6 \%)$ premium. We assume small installers and national integrators are both subject to a $15 \%(\$ 0.06 / \mathrm{W})$ premium on the spot price for module shipping and handling (Fu, Feldman, and Margolis 2018). Small installers are subject to an additional 20\% $(\$ 0.09 / \mathrm{W})$ premium owing to small-scale procurement (Bloomberg 2018), which is consistent with an assumed 20\% premium in the Q1 2017 residential PV benchmark (Fu et al. 2017). Both types of companies are also subject to $5 \%$ sales tax (weighted national average), bringing the small installer's monocrystalline module cost to $\$ 0.61 / \mathrm{W}$ and the national integrator's cost to $\$ 0.52 / \mathrm{W}$.

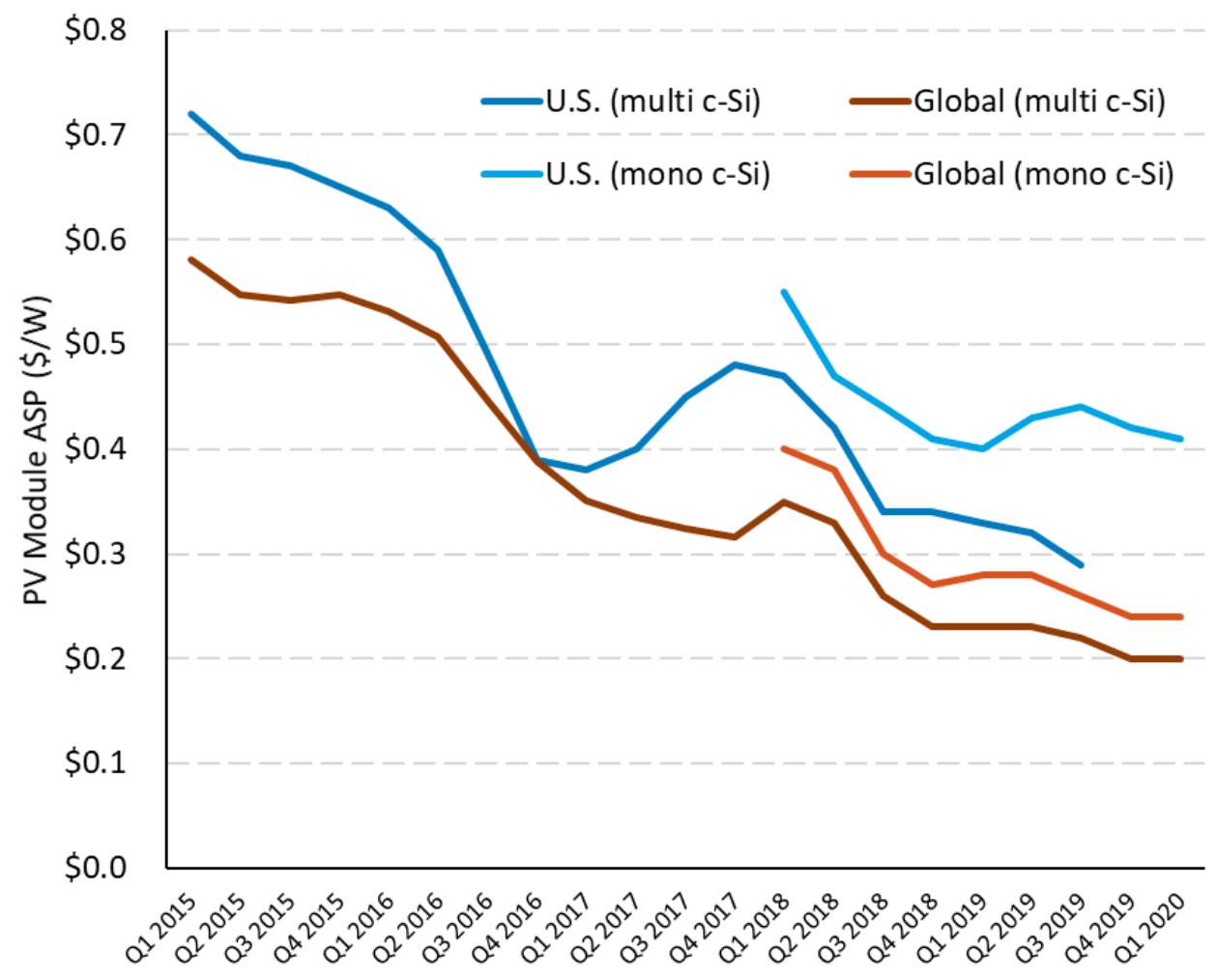

Figure 7. Ex-factory gate prices (spot prices) for U.S. and global multicrystalline and monocrystalline modules, from Wood Mackenzie and SEIA (2020) data

Global monocrystalline module prices before 2018 are from PVinsights (2019). 


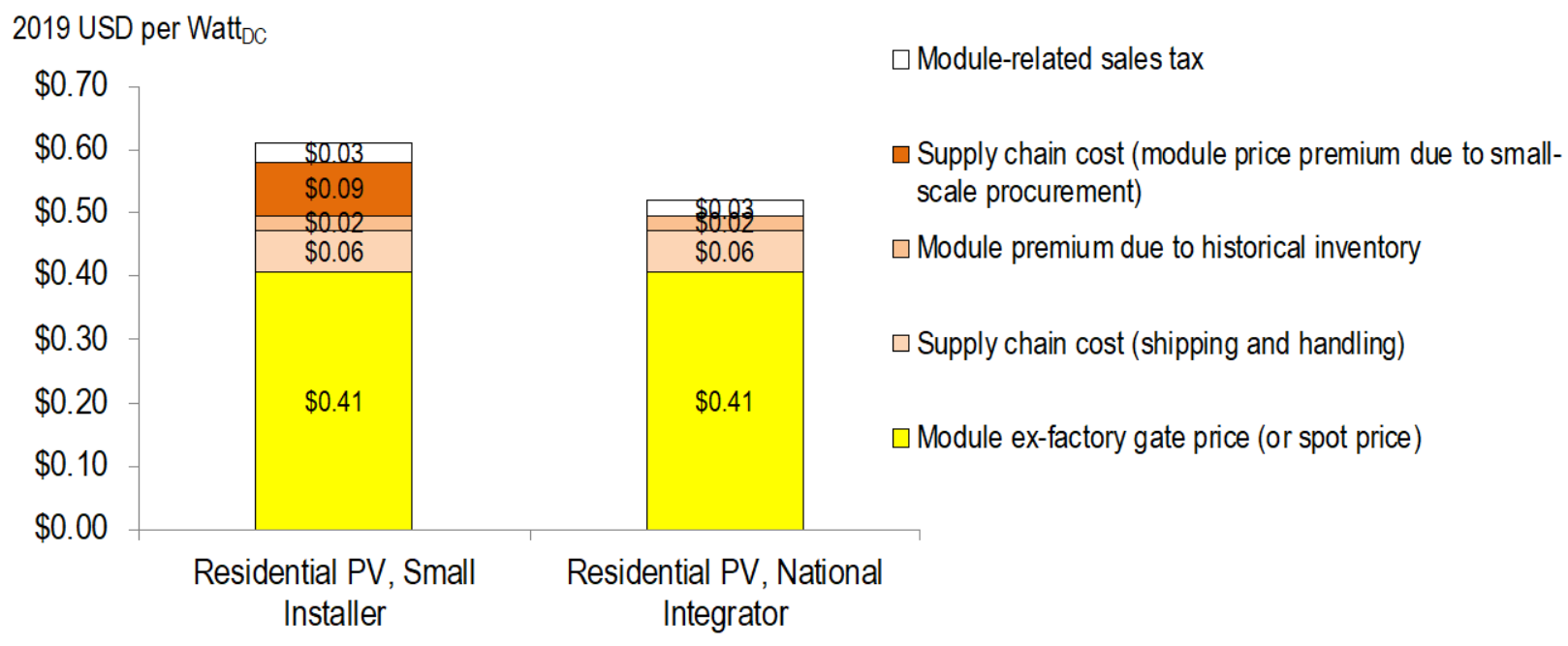

Figure 8. Total residential PV module market costs (2019 USD)

\subsection{Battery Storage}

As Figure 9 shows, lithium-ion (Li-ion) battery spot prices declined substantially ( $87 \%$ ) between 2010 and 2019. From 2018 to 2019 alone, prices dropped 13\%. The Li-ion battery pack price from Bloomberg New Energy Finance (BNEF) refers to the volume-weighted average of automotive and stationary storage. The stationary battery market has a slightly higher price. There is also price variation for different battery durations. In previous years, we used the volume-weighted average (i.e., the "Li-ion battery pack" price) because of a lack of data for stationary storage with different durations. In this year's report, we use BNEF (2019b) stationary storage cost data, differentiated by market segment and hours of storage. Although not referenced in this report, BNEF also provides commercial and utility battery rack data for 30 minute and 2-hour storage products.

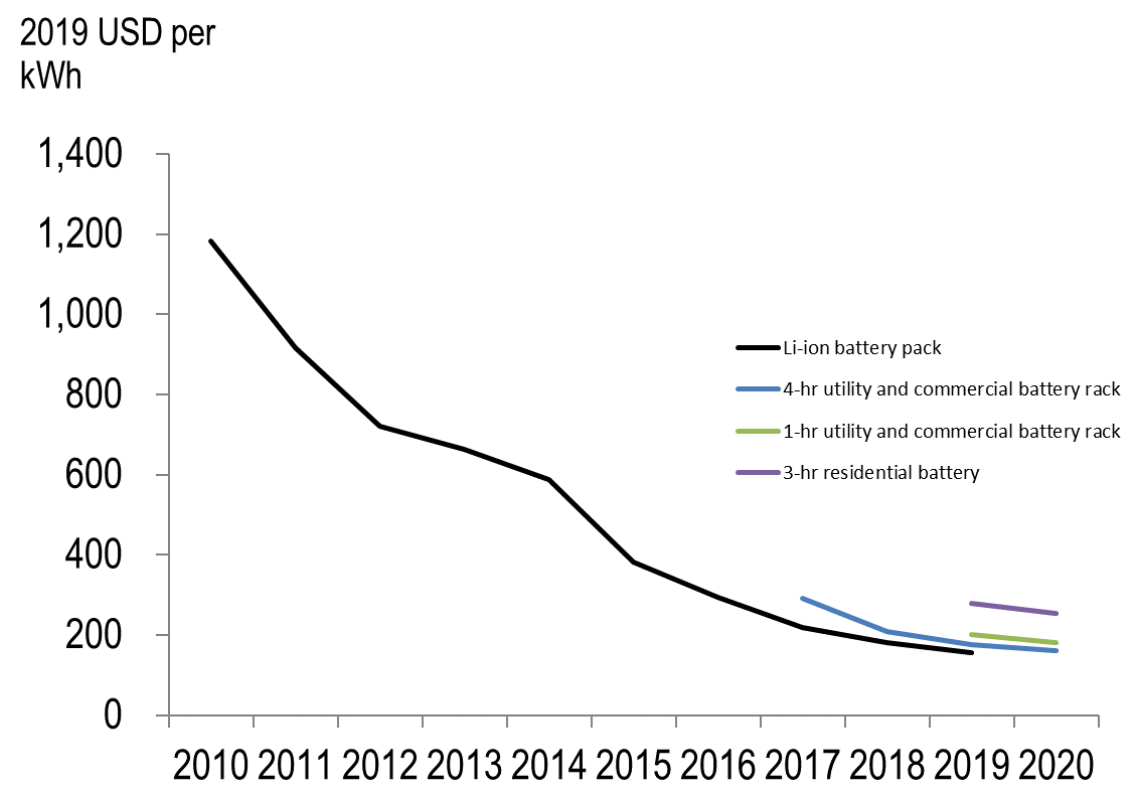

Figure 9. Ex-factory gate prices (spot prices) for Li-ion batteries by product, from BNEF (2018, 2019a, 2019b) data 


\subsection{PV LCOE Methods}

Although LCOE is not a perfect metric to measure the competiveness of PV within the energy marketplace, it does incorporate many PV metrics - beyond upfront installation costs - that are important to energy costs. For a previous edition of this report (Fu et al. 2017), we performed a literature review to determine inputs not already benchmarked in the report. When LCOE assumptions were not found in the selected literature in a given year, straight-line changes were assumed between any two values. This year, we inform the inputs using ongoing NREL benchmarking work. We input these assumptions into NREL's System Advisor Model, a performance and financial model, ${ }^{13}$ to calculate real LCOEs (considering inflation) for various locations.

\section{Annual Degradation}

In January 2018, NREL and DOE interviewed nine independent engineers and PV project financiers; they said they assume an annual PV module degradation of $0.7 \%$ per year. For certain projects with specific project and system characteristics that have been well vetted, some independent engineers assume a $0.5 \%$ annual degradation (Feldman, Jones-Albertus, and Margolis 2018). Because this lower value only applies to specific projects, we benchmark the higher degradation rate.

\section{Operation and Maintenance}

In fiscal year 2018, a PV operation and maintenance (O\&M) working group that was convened under the sponsorship of DOE's SETO developed a model to calculate the cost associated with PV system O\&M (Walker et al. 2020). Measures of O\&M in the cost model correlate to the PV O\&M services described by a best practices guide (NREL et al. 2018). Some of the O\&M cost drivers in the model are informed by actuarial failure and repair data from Sandia National Laboratories (Klise et al. 2018), but current default values reflect the best judgement of the working group for measures with unavailable data. In the current version of the model, labor rates, inverter replacement cost, discount rate, inflation rate, and capital expenditures are adjusted to fiscal year 2019. Apart from these updates, actuarial failure and repair data are updated for a few measures (insulated-gate bipolar transistor matrix, broken modules, inverter fan motors, inverter reboot, damaged racking, tracker controller, and tracker bearings) (Gunda and Homan forthcoming). For this version, five additional line measures (land lease, property taxes, insurance, asset management, and security) are added based on feedback collected by LBNL from U.S. solar industry professionals (Wiser et al. 2020).

O\&M costs in the Walker et al. (2020) O\&M cost model include preventive maintenance, scheduled at regular intervals with costs increasing at an inflationary rate, as well as corrective maintenance to replace components. The model derives corrective maintenance by multiplying the replacement cost, including labor, by the probability that a failure will occur each year based on actuarial data. Component failure probabilities for each year are calculated using a Weibull, log-normal, or other distribution based on actual data, when possible.

As shown in Figure 10, 133 measures in the cost model are sorted into nine O\&M cost categories: inverter replacement, operations administration, module replacement, components

\footnotetext{
${ }^{13}$ See https://sam.nrel.gov/.
} 
parts replacement, system inspection and monitoring, module cleaning and/or vegetation and pest management, land lease, property tax, and insurance, asset management, and security.The current benchmarks are $\$ 28.94 / \mathrm{kW}_{\mathrm{DC}} / \mathrm{yr}$ (residential), $\$ 18.55 / \mathrm{kW}$ DC $/ \mathrm{yr}$ (commercial; roof mount), $\$ 18.71 / \mathrm{kW}$ DC $/ \mathrm{yr}$ (commercial; ground mount), $\$ 16.32 / \mathrm{kW}$ DC $/ \mathrm{yr}$ (utility-scale, fixed-tilt), and $\$ 17.46 / \mathrm{kW}_{\mathrm{DC}} / \mathrm{yr}$ (utility-scale, single-axis tracking).

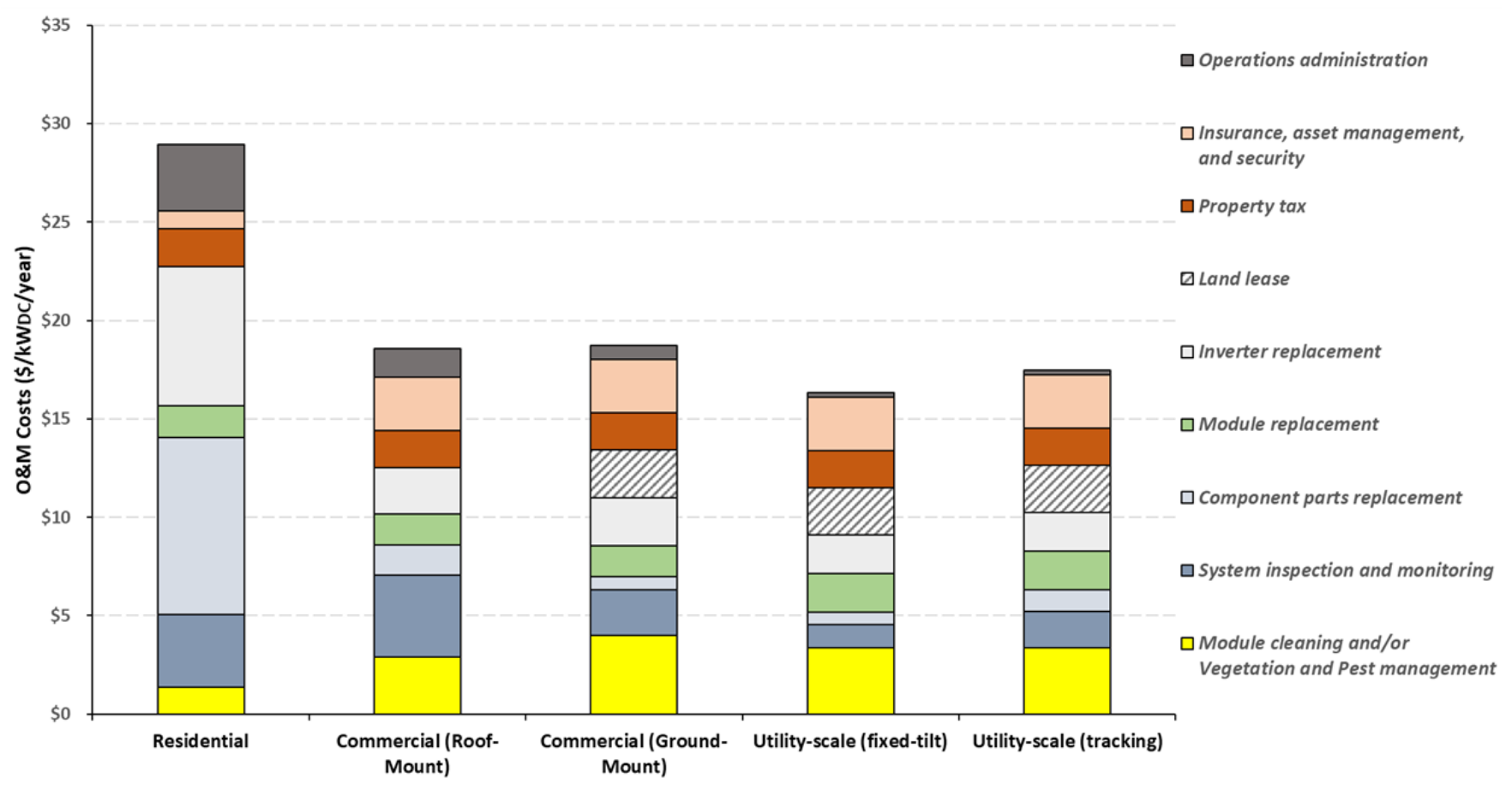

Figure 10. Q1 2020 residential, commercial, and utility-scale O\&M costs by category

\section{System Losses}

Energy losses occur between PV generation and output to the grid owing to AC and DC wiring losses, soiling, inverter mismatches, and shading and snow loading for certain systems. We aggregate the losses into two categories: $9.5 \%$ of electricity lost from preinverter derate (DC losses) and $2.0 \%$ of energy lost from inverter efficiency (AC losses).

Based on data analyzed by NREL, previous system loss benchmarks are consistent with current performance in the field, so these benchmarks have not been changed for 2020. We do assume a higher-voltage inverter in this year's utility-scale PV benchmark: 1,500 V rather than the 1,000 $\mathrm{V}$ used previously. However, increasing voltage typically has a negligible overall impact on losses. On the DC side, increasing voltage reduces conductor losses per length of conductor, yet system layouts typically move to longer string lengths, resulting in similar overall losses on the DC side (although cost is reduced). On the AC side, AC loss factors have little to do with the DC system voltage, so the AC losses will typically not change with higher DC voltages.

\section{Financing}

The 2019 and 2020 financing assumptions are based on Feldman, Bolinger, and Schwabe (2020); financing costs in that report are lower than in previous benchmark work (Feldman, Lowder, and Schwabe 2016; Feldman and Schwabe 2017, 2018). All data compiled for these reports are 
derived from a combination of basic literature reviews, product research, and interviews with industry professionals.

The financing values represent current financing structures, which depend on the investment tax credit (ITC). Although the ITC represents a net positive for projects, financing costs (but not LCOE) would be lower without the ITC (Feldman, Bolinger, and Schwabe 2020). In our benchmark reports, we have historically reported LCOE with current financing costs (which are based on owners using the ITC) without an ITC, which is incongruous. In this year's report, we calculate LCOE assuming long-term steady-state financing assumptions, with no ITC and with interest rates higher than current historically low levels. 


\section{Residential PV Model}

This section describes our residential PV model's structure, inputs, and assumptions (Section 3.1); expanded "other soft costs" modeling" (3.2); model output (3.3); differences between modeled output and reported costs (3.4); differences between retrofits and new construction (3.5); additional costs typical of residential PV installation (3.6); and historical PV price (3.7) and LCOE (3.8) trends.

\subsection{Residential Model Structure, Inputs, and Assumptions}

We model a 7.0-kW residential rooftop system using 60-cell, monocrystalline, 19.5\%-efficient modules from a Tier 1 supplier and a standard flush mount, pitched-roof racking system. Figure 11 presents the cost drivers and assumptions, cost categories, inputs, and outputs of the model. Table 3 presents modeling inputs and assumptions in detail.

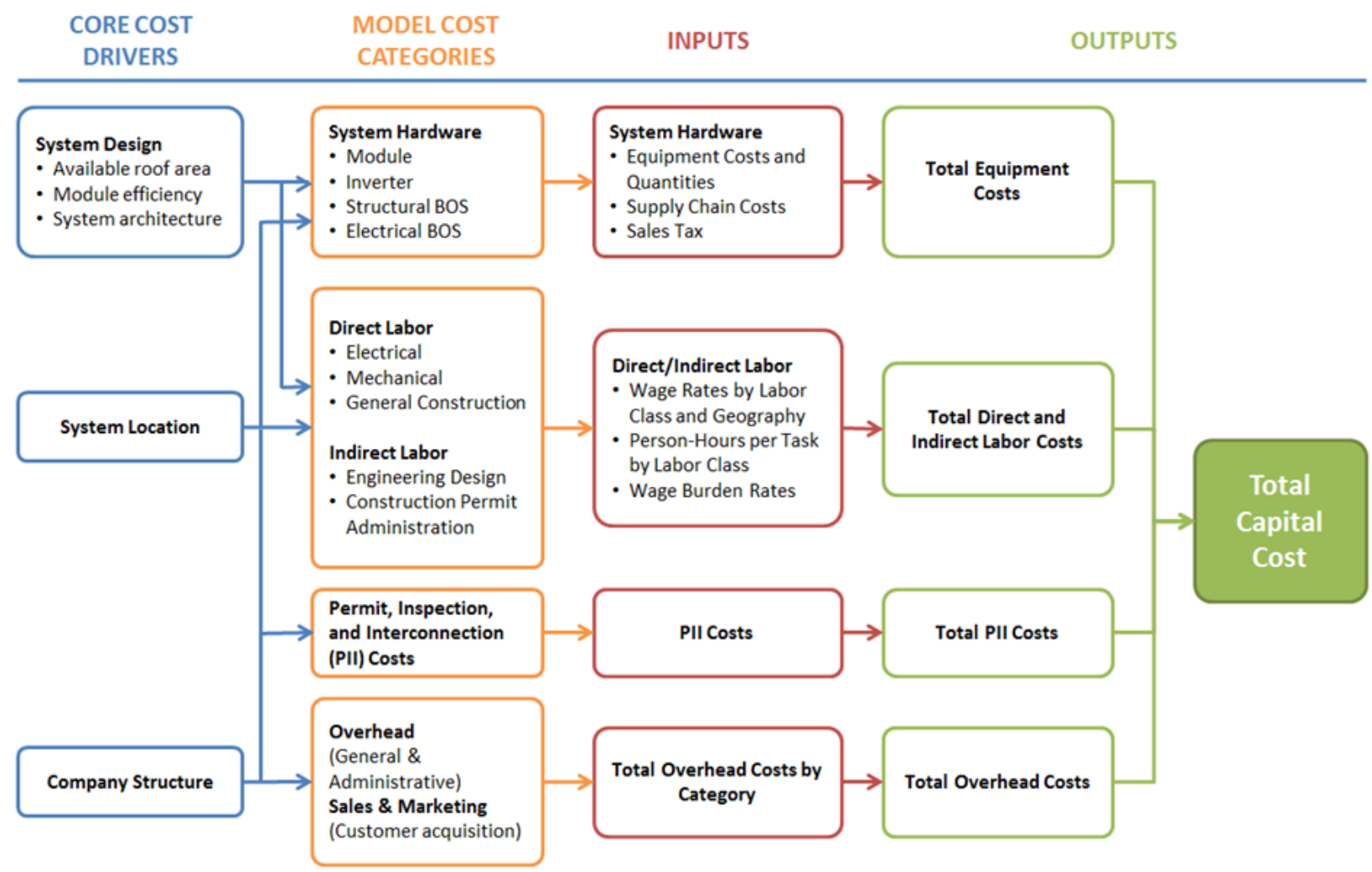

Figure 11. Residential PV: Model structure

BOS $=$ balance of system 
Table 3. Residential PV: Modeling Inputs and Assumptions

\begin{tabular}{|c|c|c|c|}
\hline Category & Modeled Value & Description & Sources \\
\hline System size & $7.0 \mathrm{~kW}$ & $\begin{array}{l}\text { Average installed size per } \\
\text { system }\end{array}$ & $\begin{array}{l}\text { Barbose and } \\
\text { Darghouth } 2019 ; \\
\text { CA NEM } 2020\end{array}$ \\
\hline Module efficiency & $19.5 \%$ & Average module efficiency & CA NEM 2020 \\
\hline Module price & $\$ 0.41 / \mathrm{W}_{\mathrm{DC}}$ & $\begin{array}{l}\text { Ex-factory gate (first buyer) } \\
\text { price, Tier } 1 \text { monocrystalline } \\
\text { modules }\end{array}$ & $\begin{array}{l}\text { Wood Mackenzie } \\
\text { and SEIA } 2020\end{array}$ \\
\hline \multirow[t]{2}{*}{ Inverter price } & $\begin{array}{l}\text { Single-phase string } \\
\text { inverter: } \$ 0.14 / W_{D C}\end{array}$ & $\begin{array}{l}\text { Ex-factory gate (first buyer) } \\
\text { prices, Tier } 1 \text { inverters }\end{array}$ & \multirow{2}{*}{$\begin{array}{l}\text { Wood Mackenzie } \\
\text { 2020; Wood } \\
\text { Mackenzie and } \\
\text { SEIA } 2020\end{array}$} \\
\hline & $\begin{array}{l}\text { DC power optimizer } \\
\text { single-phase string } \\
\text { inverter: } \$ 0.26 / W_{D C} \\
\text { Microinverter: } \\
\$ 0.29 / W_{D C}\end{array}$ & & \\
\hline $\begin{array}{l}\text { Structural BOS } \\
\text { (racking) }\end{array}$ & $\$ 0.08 / \mathrm{W}_{\mathrm{DC}}$ & $\begin{array}{l}\text { Includes flashing for roof } \\
\text { penetrations and all rails and } \\
\text { clamps }\end{array}$ & NREL 2020 \\
\hline \multirow[t]{2}{*}{ Electrical BOS } & $\$ 0.18-\$ 0.28 / W_{D C}$ & \multirow[b]{2}{*}{$\begin{array}{l}\text { Conductors, switches, } \\
\text { combiners and transition } \\
\text { boxes, as well as conduit, } \\
\text { grounding equipment, } \\
\text { monitoring system or } \\
\text { production meters, fuses, } \\
\text { and breakers }\end{array}$} & \multirow{2}{*}{$\begin{array}{l}\text { Model assumptions, } \\
\text { NREL } 2020\end{array}$} \\
\hline & $\begin{array}{l}\text { Varies by inverter } \\
\text { option }\end{array}$ & & \\
\hline \multirow{4}{*}{$\begin{array}{l}\text { Supply chain } \\
\text { costs (percentage } \\
\text { of equipment } \\
\text { costs) }\end{array}$} & \multirow[t]{4}{*}{$\begin{array}{l}\text { Varies by installer } \\
\text { type and location }\end{array}$} & $\begin{array}{l}15 \% \text { costs and fees } \\
\text { associated with shipping and } \\
\text { handling of equipment }\end{array}$ & \multirow[t]{4}{*}{$\begin{array}{l}\text { BLS 2019; } \\
\text { NREL 2020; } \\
\text { model assumptions }\end{array}$} \\
\hline & & $\begin{array}{l}\text { Additional } 6 \% \text { cost for } \\
\text { historical inventory }\end{array}$ & \\
\hline & & $\begin{array}{l}\text { Additional } 20 \% \text { small-scale } \\
\text { procurement for module- } \\
\text { related supply chain costs for } \\
\text { small installers }\end{array}$ & \\
\hline & & $\begin{array}{l}\text { Additional } 20 \% \text { for inverter- } \\
\text { related supply chain costs for } \\
\text { small installers and } 10 \% \text { for } \\
\text { national integrators }\end{array}$ & \\
\hline Sales tax & $\begin{array}{l}\text { National average: } \\
5.1 \%\end{array}$ & Sales tax on the equipment & RSMeans 2017 \\
\hline \multirow[t]{3}{*}{$\begin{array}{l}\text { Direct installation } \\
\text { labor }\end{array}$} & $\begin{array}{l}\text { Electrician: } \$ 27.47 \\
\text { per hour }\end{array}$ & \multirow[t]{3}{*}{$\begin{array}{l}\text { Modeled national average } \\
\text { labor rates }\end{array}$} & \multirow[t]{3}{*}{ BLS 2019; NREL 2020} \\
\hline & $\begin{array}{l}\text { Laborer: } \$ 18.17 \\
\text { per hour }\end{array}$ & & \\
\hline & $\begin{array}{l}\text { Hours vary by } \\
\text { inverter option }\end{array}$ & & \\
\hline
\end{tabular}




\begin{tabular}{|c|c|c|c|}
\hline Category & Modeled Value & Description & Sources \\
\hline $\begin{array}{l}\text { Burden rates } \\
\text { (percentage of } \\
\text { direct labor) }\end{array}$ & $\begin{array}{l}\text { Total nationwide } \\
\text { average: } 18 \%\end{array}$ & $\begin{array}{l}\text { Workers compensation, } \\
\text { federal and state } \\
\text { unemployment insurance, } \\
\text { Federal Insurance } \\
\text { Contributions Act (FICA), } \\
\text { builder's risk, and public } \\
\text { liability }\end{array}$ & RSMeans 2017 \\
\hline \multirow[t]{3}{*}{ PII } & $\begin{array}{l}\$ 0.23 / W_{D C} \text { for small } \\
\text { installers }\end{array}$ & \multirow{3}{*}{$\begin{array}{l}\text { Completed and submitted } \\
\text { applications, fees, design } \\
\text { changes, and field inspection }\end{array}$} & \multirow[t]{3}{*}{ NREL 2020} \\
\hline & $\begin{array}{l}\$ 0.25 / W_{D C} \text { for } \\
\text { national integrators }\end{array}$ & & \\
\hline & Varies by location & & \\
\hline \multirow{3}{*}{$\begin{array}{l}\text { Sales and } \\
\text { marketing } \\
\text { (customer } \\
\text { acquisition) }\end{array}$} & $\begin{array}{l}\$ 0.38 / W_{D C} \text { (small } \\
\text { installer) }\end{array}$ & \multirow{3}{*}{$\begin{array}{l}\text { Initial and final drawing plans, } \\
\text { advertising, lead generation, } \\
\text { sales pitch, contract } \\
\text { negotiation, and customer } \\
\text { interfacing }\end{array}$} & \multirow[t]{3}{*}{ NREL 2020} \\
\hline & $\begin{array}{l}\$ 0.50 / \mathrm{W}_{\mathrm{DC}} \text { (national } \\
\text { integrator) }\end{array}$ & & \\
\hline & Varies by location & & \\
\hline \multirow{3}{*}{$\begin{array}{l}\text { Overhead } \\
\text { (general and } \\
\text { administrative) }\end{array}$} & $\begin{array}{l}\$ 0.27 / \mathrm{W}_{\mathrm{DC}} \text { (small } \\
\text { installer) }\end{array}$ & \multirow{3}{*}{$\begin{array}{l}\text { Rent, building, equipment, } \\
\text { staff expenses not directly } \\
\text { tied to PII, customer } \\
\text { acquisition, or direct } \\
\text { installation labor }\end{array}$} & \multirow[t]{3}{*}{ NREL 2020} \\
\hline & $\begin{array}{l}\$ 0.28 / W_{D C} \text { (national } \\
\text { integrator) }\end{array}$ & & \\
\hline & Varies by location & & \\
\hline Profit (\%) & $17 \%$ & $\begin{array}{l}\text { Fixed percentage margin } \\
\text { applied to all direct } \\
\text { costs including hardware, } \\
\text { installation labor, direct sales } \\
\text { and marketing, design, } \\
\text { installation, and permitting } \\
\text { fees }\end{array}$ & Fu et al. 2017 \\
\hline
\end{tabular}

\subsection{Expanded "Other Soft Costs" Modeling}

In this year's benchmark analysis, we expand our modeling of customer acquisition, engineering, PII, and overhead. In addition to providing finer cost granularity, we include additional costs borne by many U.S. installers that were not captured in previous editions; therefore, our benchmarked soft costs in this report are higher than those in previous reports. The first four cost categories estimate costs by looking at the necessary steps taken to sell, engineer, permit, and interconnect a residential PV system. Each task requiring staff time is categorized by department (e.g., sales and permitting). The last category, overhead, estimates costs by itemizing expenses of all staff time and resources necessary to operate a residential PV installation company, but which are not directly tied to a specific installation. Each method is described in detail below.

Customer acquisition costs are estimated by breaking down the process into the following steps: advertisement, lead generation, qualifications/first sales pitch, and final sales pitch. Within each step are various methods that may be used to acquire a customer. The cost contribution to total PV system cost for each step is calculated by multiplying (1) the average cost per occurrence (based on a fee or an hourly wage and the number of hours) by (2) the estimated 
percentage of national sales that use this step divided by (3) the average conversion from this step to an installed system. Multiplying the cost per occurrence by the estimated percentage of national sales is done to provide a national average, whereas dividing by the average conversion is needed to account for the costs incurred by the company from potential customers who do not end up purchasing a PV system from the installer. The data in this section were compiled from public securities filings (i.e., 10-Ks), analyst reports and presentations, as well as conversations with those involved in the residential PV customer acquisition business.

Engineering costs summarize the costs associated with designing initial and final system plans. The cost contribution to total PV system cost for each step is calculated by multiplying (1) the average cost per occurrence (or hourly wage multiplied by the number of hours) by (2) the estimated percentage of national sales that use this step divided by the (3) average conversion from this step to an installed system. Multiplying the cost per occurrence by the estimated percentage of national sales is done to provide a national average, whereas dividing by the average conversion is needed to account for the costs incurred by the company from potential customers who do not end up purchasing a PV system from the installer. The data in this section were compiled by averaging costs reported from private conversations with residential PV installers.

Permitting, inspection, and interconnection categories summarize the costs associated with applying for and receiving a permit or interconnection agreement from an "authority having jurisdiction." The cost contribution to total PV system cost for each permitting or interconnection step is calculated by multiplying (1) the average cost per occurrence (either a fee, cost [e.g., mileage], or hourly wage multiplied by the number of hours) by (2) the estimated percentage of national sales that use this step divided by (3) the average conversion from this step to an installed system. Multiplying the cost per occurrence by the estimated percentage of national sales is done to provide a national average, whereas dividing by the average conversion is needed to account for the costs incurred by the company from potential customers who do not end up purchasing a PV system from the installer. The data in this section were compiled by averaging costs reported from private conversations with residential PV installers.

Overhead summarizes the costs associated with providing the business platform and infrastructure to sell, permit, install, and interconnect a residential PV system. It is divided into two large categories: business expenses (e.g., rent, office equipment, and professional services) and staff expenses. Staff expenses for national integrators include the "C-suite" executives, treasurers, customer service staff, supply chain staff, and information technology staff; staff expenses for small installers include principals, engineers, sales team members, and administrators. The model also estimates the total staff time attributed directly to selling, engineering, permitting, and interconnecting a PV system, as well as the percentage of time for each position associated with direct project costs. The number of hours spent on projects is calculated by multiplying the hours spent per PV system for an individual cost category by the number of systems built in that year. For example, if 10 sales-hours were required per system installed, on average, and 400 PV systems were installed in a year, total sales staff time spent on projects in that year would be 4,000 hours. Furthermore, if sales staff spent two thirds of their time directly on projects, total sales staff time would be 6,000 hours per year (or 4,000 divided by two thirds). The 6,000 hours translates into three staff members (i.e., 6,000 divided by 2,000 - the number of work-hours in a year [ 50 weeks, 40 hours per week — assuming two weeks 
of vacation per year]). Annual salary is estimated by (1) multiplying the hourly wages for staff associated directly with projects (based on private conversations with installers) by the number of paid hours in a year $(52 \times 40)$ or $(2)$ for those not directly associated with projects, by estimating the average salary of that position in a company, using available published data. Base salaries are also grossed to account for other corporate costs, such as benefits, FICA, and bonuses. Total staff, per category, is based on the number of systems installed, the number of megawatts installed, or the ratio of employee category per total staff size.

\subsection{Residential Model Output}

Figure 12 presents the U.S. national benchmark from our residential PV model. Market shares of $62 \%$ for small installers and $38 \%$ for national integrators are used to compute the national weighted average. String inverter, power optimizer, and microinverter options are each modeled individually, and the "mixed" case applies their market shares $(14.6 \%, 49.8 \%$, and $35.6 \%)$ as weightings.

Figure 13 shows a sensitivity analysis for the mixed case, with cost categories that vary by location and hardware specification. Inverter type has the largest impact on installed system cost, with use of string inverters resulting in $\$ 2.47 / \mathrm{W}_{\mathrm{DC}}$ and use of microinverters resulting in $\$ 2.83 / \mathrm{W}_{\mathrm{DC}}$. 
per Watt DC

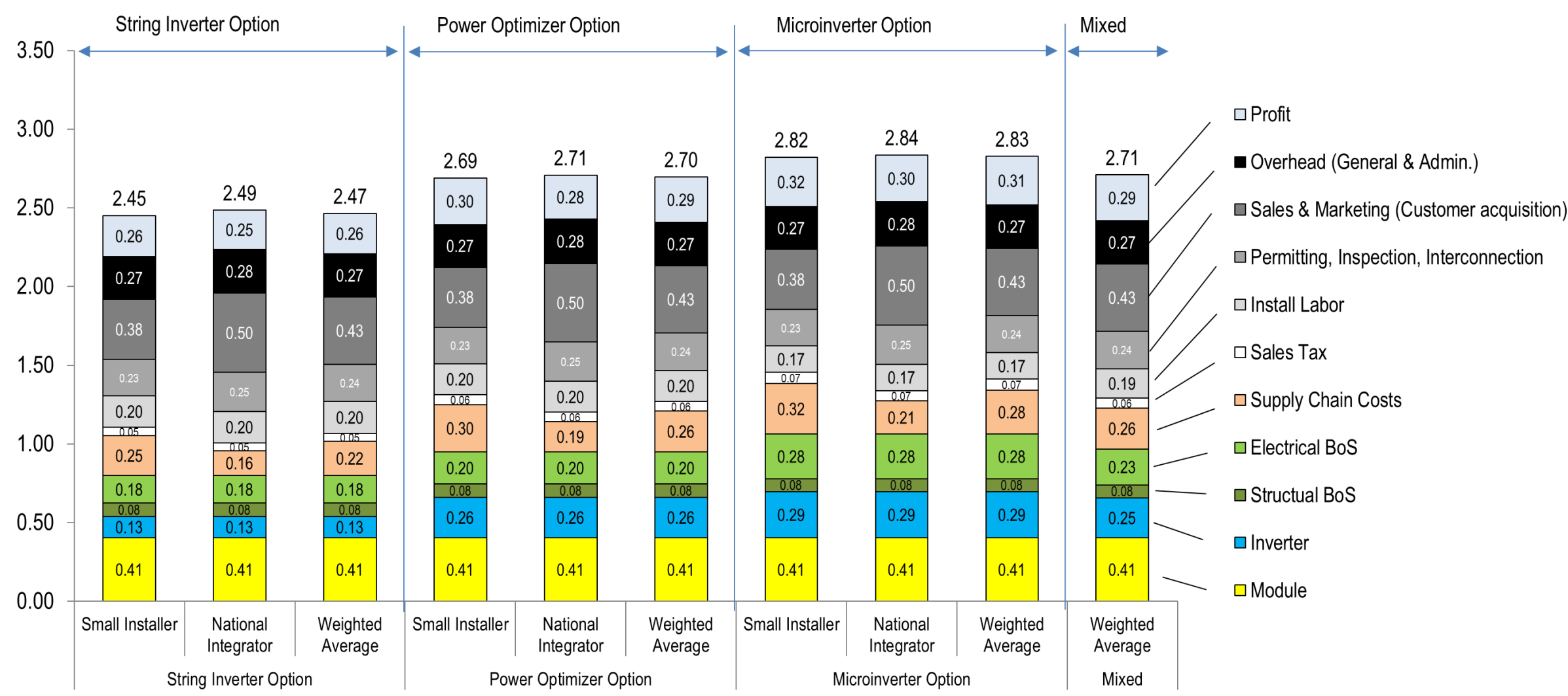

Figure 12. Q1 2020 U.S. benchmark: 7.0-kW residential PV system cost (2019 USD/WDC) 


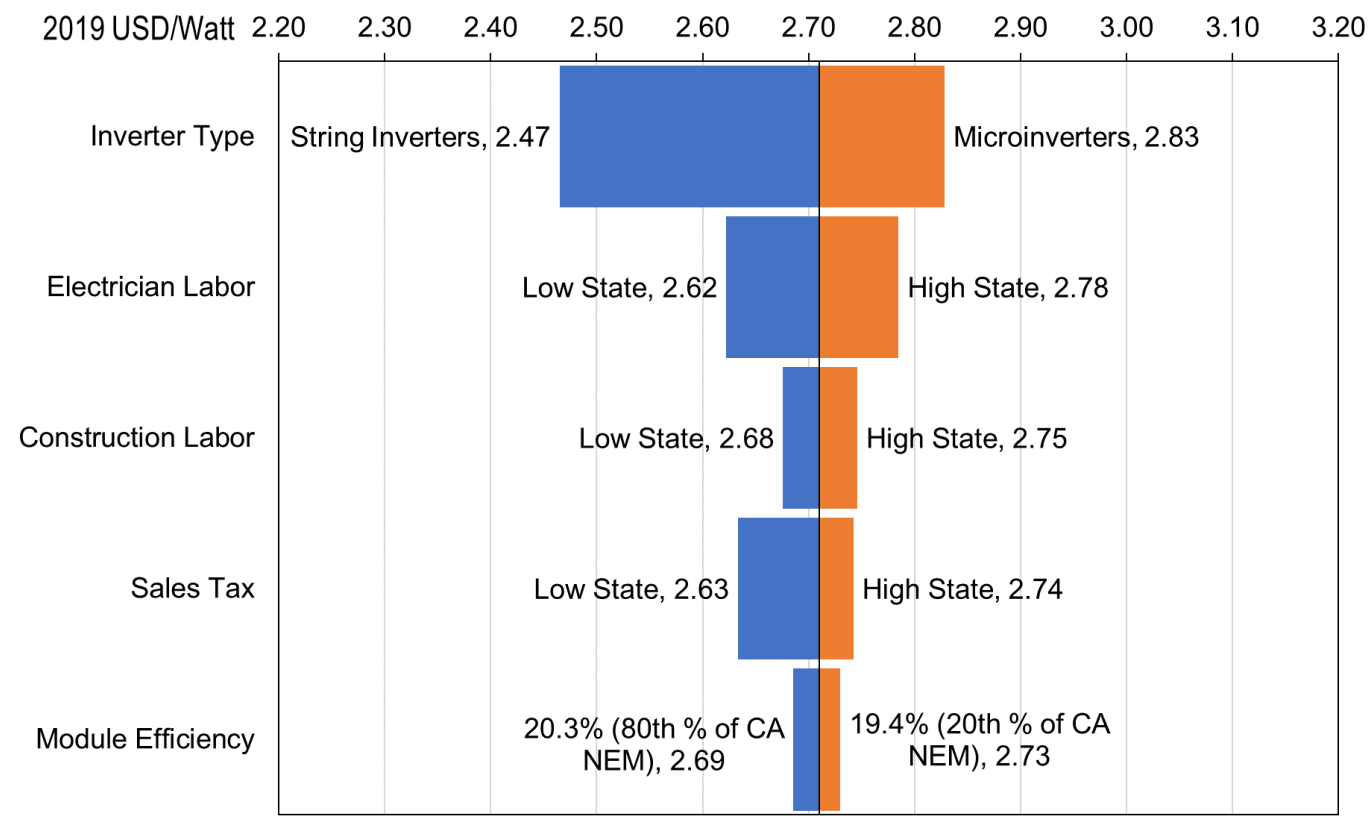

Figure 13. Sensitivity analysis for the Q1 2020 benchmark: Mixed 7.0-kW residential system cost (2019 USD/W

\subsection{Residential Model Output versus Reported Costs}

As shown in Figure 14, our bottom-up modeling approach yields a different cost structure than those reported by public solar integrators in their corporate filings (e.g., Sunrun 2020, Vivint Solar 2020). Because national integrators sell and lease PV systems, they practice a different method of reporting costs than do businesses that only sell goods. Many of the costs for leased systems are reported over the life of the lease rather than the period in which the system is sold; therefore, determining the actual costs at the time of sale is difficult. Although Sunrun and Vivint Solar report system costs in their corporate filings on a quarterly basis (but not "profit" per system), the limited transparency in the public filings makes it difficult to determine the underlying costs as well as the timing of those costs. Because of the lack of available reported company costs, explaining these differences entirely is difficult, and this topic is worthy of future research. Explanations of the difference in reported cost could include the following:

1. Reported companies may spend more on customer acquisition costs to grow market share.

2. Reported companies' customer acquisition costs consist of leasing, loan, and cash purchase options. Non-cash purchase options may have higher customer acquisition costs than the cash purchase model in this report. National installers also have recently spent considerable effort retraining sales teams as they have shifted focus toward offering customers a direct ownership option rather than a lease or PPA. Retraining a sales staff can be a multi-month process and add considerable expense (Wood Mackenzie and SEIA 2018). Moreover, fewer systems may be sold during the transition process, which would increase customer acquisition costs on a per-watt basis.

3. Part of the difference in installation costs could come from preexisting contracts or older inventory that national integrators used in systems installed in Q1 2020. 


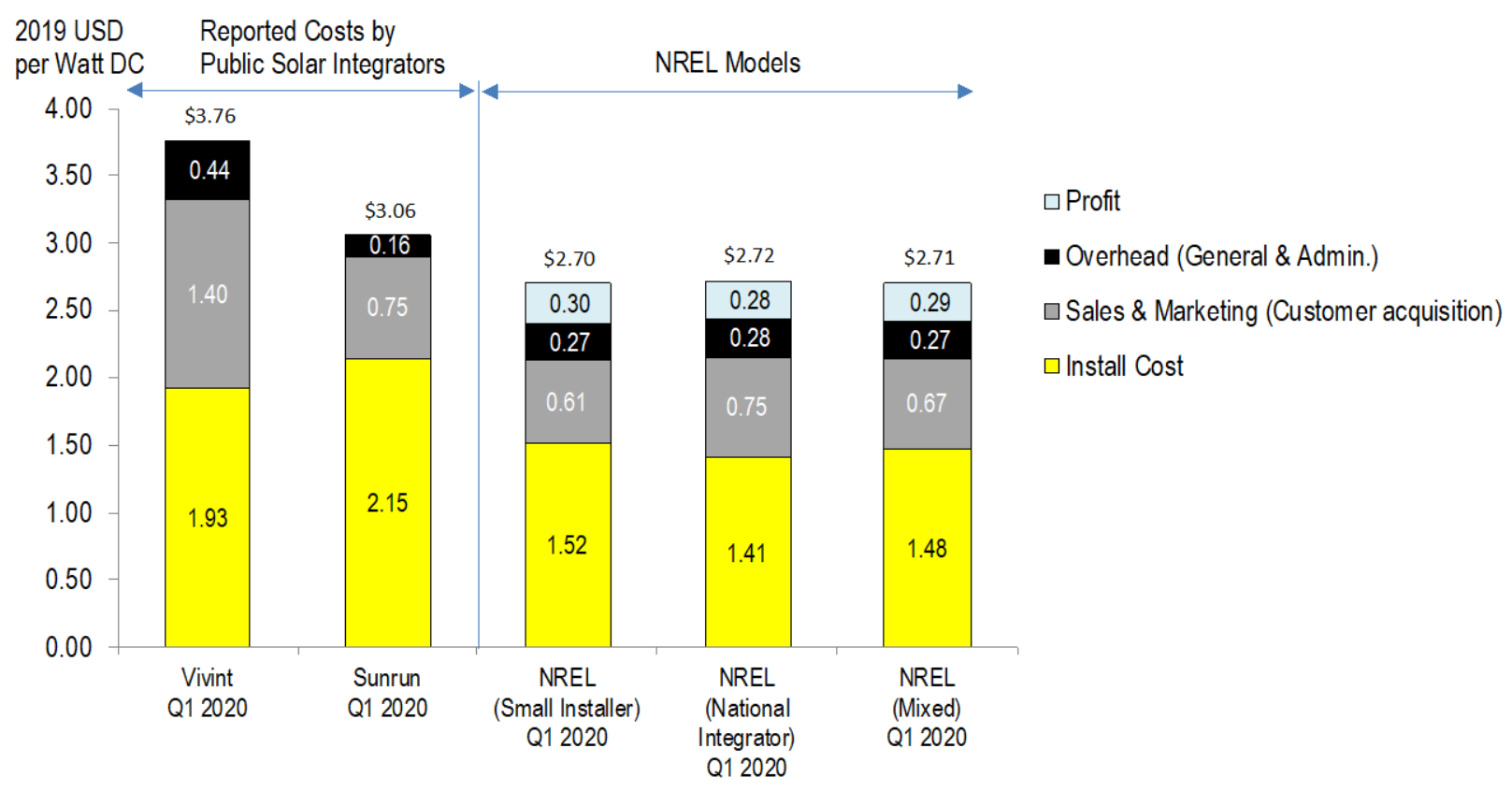

Figure 14. Q1 2020 NREL modeled cost benchmark (2019 USD/W $W_{D C}$ ) versus Q1 2020 companyreported costs

The PII cost category is included in sales and marketing.

\subsection{Retrofits versus New Construction}

As discussed by Ardani et al. (2018), the residential PV sector has a significant opportunity to reduce costs by installing PV systems when new homes are constructed; this is unlike most of the current market, in which existing homes are retrofitted with PV systems. For comparative purposes, we build a "new construction" business structure, using the expanded modeling in this year's version of the residential PV model for customer acquisition, engineering, PII, and overhead. The new construction case assumes residential PV systems are part of the standard features of a new production home, which is akin to the legislation passed in California mandating such a practice; some developers in other states also offer production homes in new developments with residential PV systems as a default feature. ${ }^{14}$ As indicated in Figure 15, new builds are $\$ 0.65 / \mathrm{W}$ less expensive than retrofits; this is due to substantially lower customer acquisition and PII costs, as well as reduced costs through efficiencies in labor and structural BOS.

\footnotetext{
${ }^{14}$ Many of the cost savings achieved by integrating solar into production homes may not translate to custom new home PV projects, from third-party vendors, because there may still be a sales process and coordination between firms for site work (e.g., framing, roofing, electrical, plumbing, and communications), the PV design may need to be changed with design changes to home (e.g., installation of skylights), and there may be a longer time frame between contract closing and the date the system is placed in service.
} 


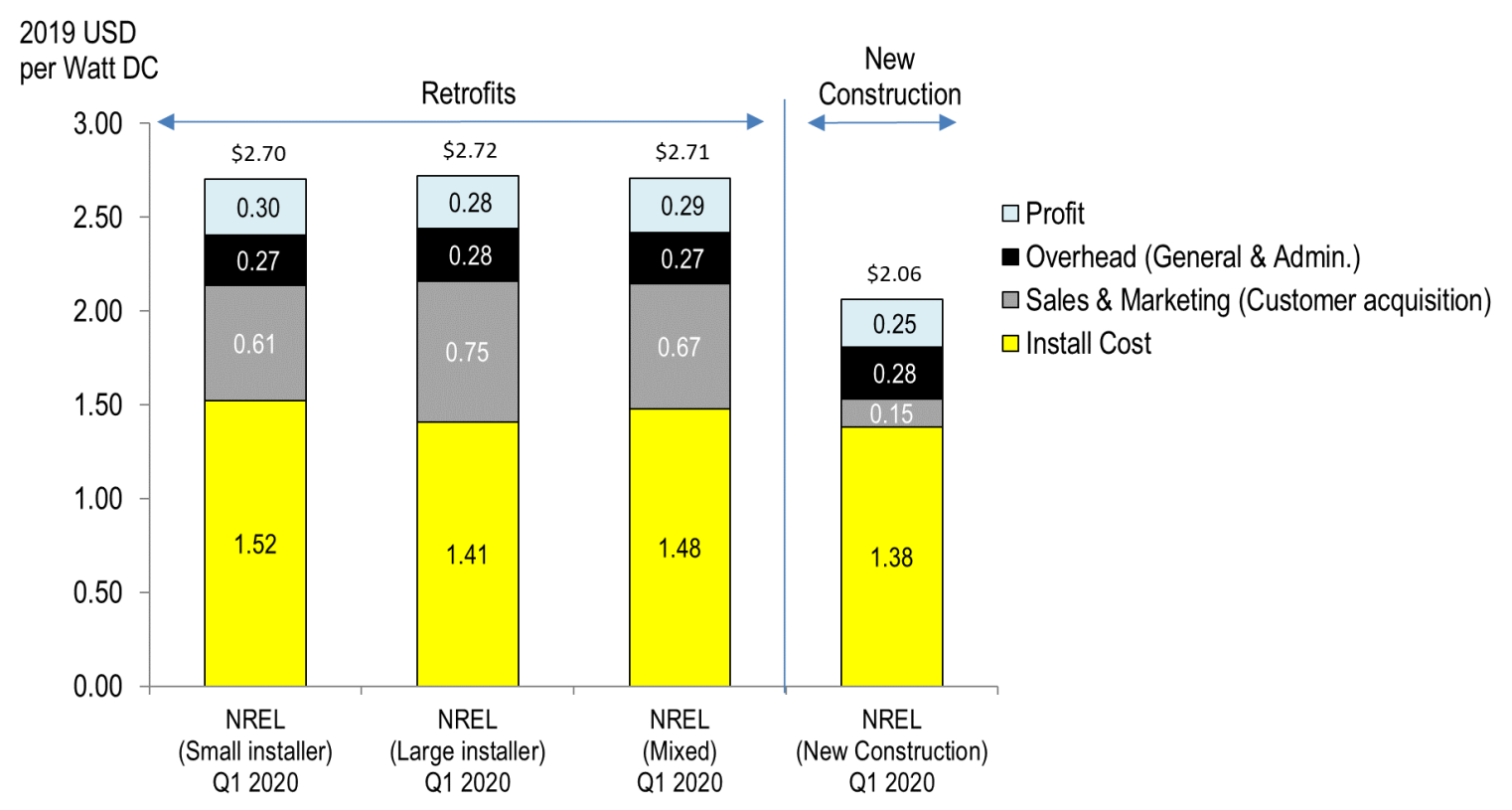

Figure 15. Q1 2020 NREL residential PV modeled cost benchmark (retrofit) versus Q1 2020 NREL residential PV modeled cost benchmark (new construction)

Cost reduction for PV in new construction occurs for a variety of reasons. There are virtually no customer acquisition costs, because the new home comes with a PV system as a standard option. Some costs are borne by the installer (e.g., "holding the customer's hand" through the PV installation and interconnection process as well as PII costs). However, PII is significantly more streamlined, because it is part of the larger permitting process for a home (or development), and installers almost never incur costs due to customer cancellation. Finally, the installation process takes less time because it is incorporated into building the roof and other parts of the new home, while material cost savings are realized by building the roof and the electrical system seamlessly with the PV system.

\subsection{Additional Costs Typical of Residential PV Installation}

Our benchmarking method includes bottom-up accounting for all necessary system and projectdevelopment costs incurred when installing U.S. residential PV systems. This year, we calculate additional hardware, installation labor, and roofing costs that are often incurred for many PV systems. Because of requirements in some authorities having jurisdiction, or for a particular building, additional hardware and installation labor costs must be incurred. These costs include partial or full reroofing, adding another disconnect, upgrading a transformer, upgrading a main panel, or being forced (for permitting or interconnection reasons) to install a smaller system than originally designed. Not all U.S. projects must incur these costs, so the average additional contribution to total PV system cost for each step is calculated by multiplying the average cost per occurrence (either material costs or hourly wage multiplied by the number of hours) by the estimated percentage of national sales that use this step, divided by the average conversion from this step to an installed system. Figure 16 summarizes the results of this analysis. The extra cost categories can add $10 \%$ to the benchmark system cost. 


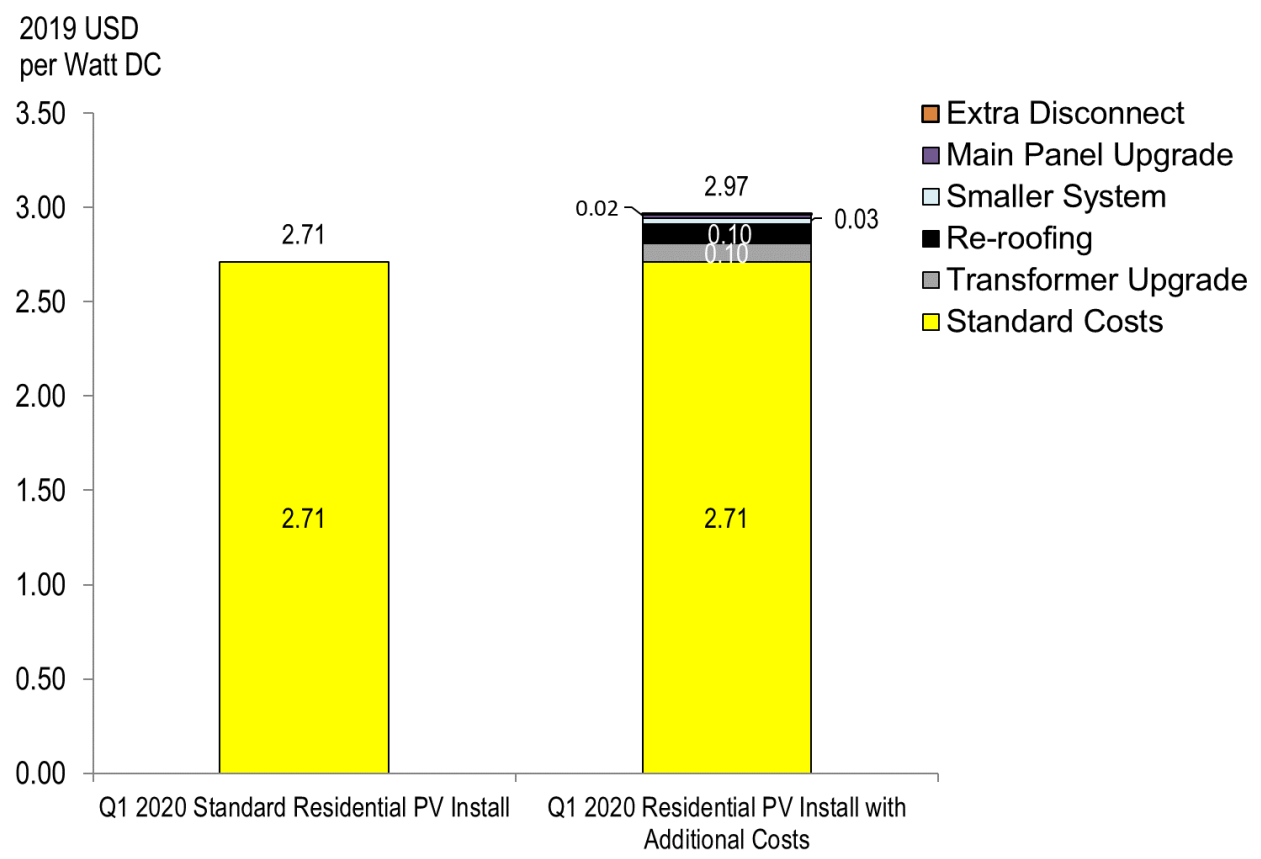

Figure 16. Standard residential PV installation costs versus cost for systems with necessary additions

\subsection{Residential PV Price Benchmark Historical Trends}

NREL began benchmarking PV system costs in 2010 to track PV costs against SETO targets and to examine cost-reduction opportunities for achieving these goals. ${ }^{15}$ Since then, NREL has produced eight additional benchmarks. The current version of our residential cost model makes a few significant changes from the version used in our Q1 2018 benchmark report (Fu, Feldman, and Margolis 2018). To better distinguish the historical cost trends over time from the changes to our cost models, we also calculate Q1 2019 and Q1 2020 PV benchmarks using the Q1 2018 version. Appendix A provides a detailed discussion of the changes made to the models between previous reports (Fu, Feldman, and Margolis 2018) and this year's report. Figure 17 summarizes the reduction in residential PV system cost benchmarks between 2010 and $2020 .{ }^{16}$ The "Additional Costs from Model Updates" category represents the difference between modeled results calculated using the current model versus the previous model. Using the previous cost model, the Q1 2019 and Q1 2020 benchmarks are $\$ 2.56 / \mathrm{W}_{\mathrm{DC}}$ and $\$ 2.47 / \mathrm{W}_{\mathrm{DC}}$, respectively.

\footnotetext{
${ }^{15}$ The original, overarching 2020 SETO goal for solar was to reach levelized cost parity with a new thermal plant, which was estimated to be $6 \notin / \mathrm{kWh}$ without subsidies, or a system installed cost of $\$ 1 / \mathrm{W}$. SETO later separated commercial and residential PV to have their own goals of costs below retail rates, which were estimated to be $7 \phi / \mathrm{kWh}$ and $9 \notin / \mathrm{kWh}$, or system installed costs of $\$ 1.25 / \mathrm{W}$ and $\$ 1.50 / \mathrm{W}$, respectively (all 2020 targets are quoted in nominal USD). In recognition of both the transformative solar progress to date and the potential for additional innovation, SETO extended its goals in 2016 to reduce the unsubsidized cost of energy by 2030 to $3 \notin / \mathrm{kWh}, 4 \notin / \mathrm{kWh}$, and $5 \phi / \mathrm{kWh}$ for utility-scale PV, commercial PV, and residential PV (all 2030 targets are quoted in nominal USD).

${ }^{16}$ Each year's PV system cost benchmark corresponds to the NREL benchmark calculted in Q4 of the previous year or Q1 of the current year (e.g., 2010=Q4 2009, $2017=$ Q1 2017).
} 


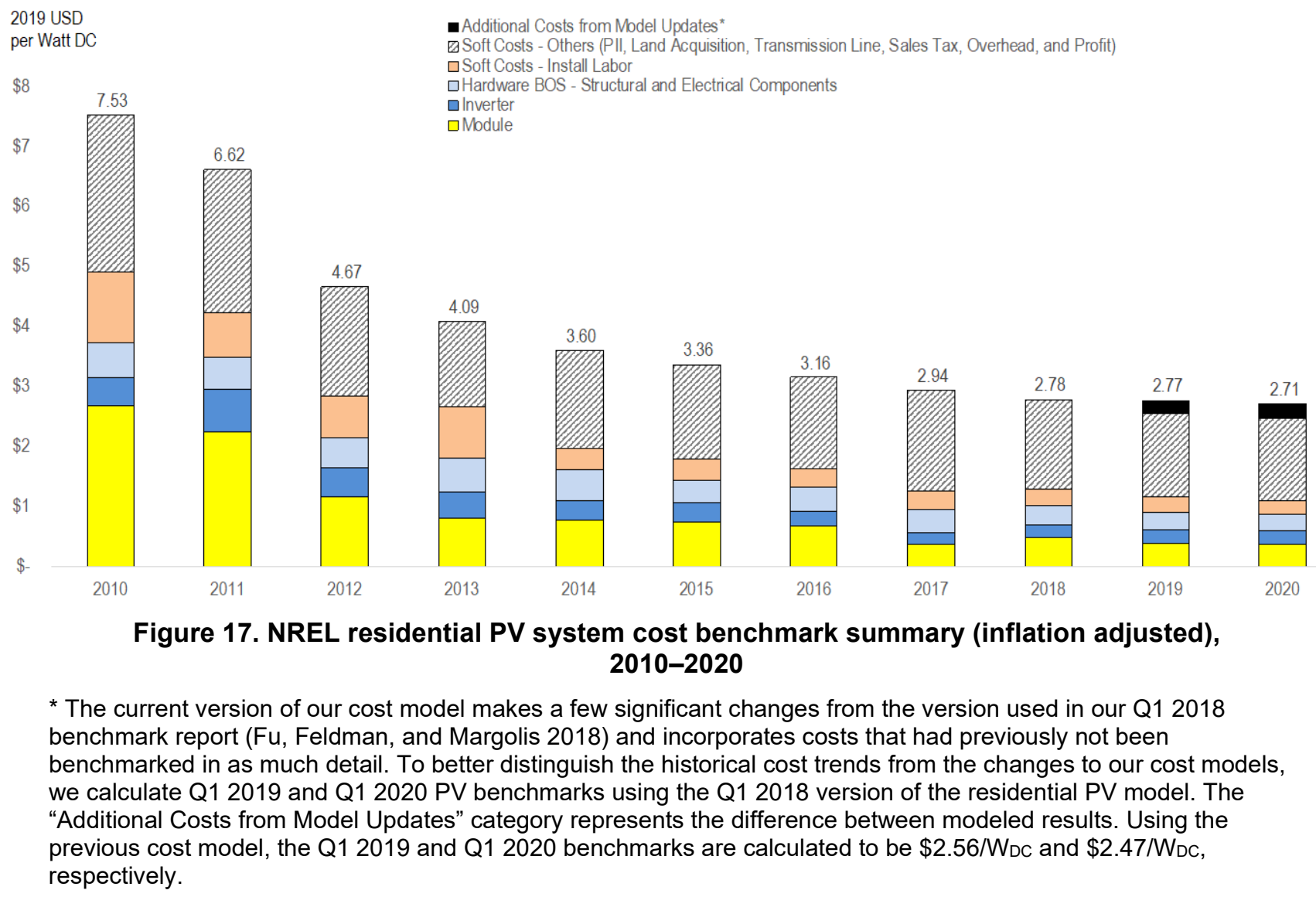

As demonstrated in Figure 17, from 2010 to 2020, there was a 64\% reduction in the residential PV system cost benchmark. Approximately $57 \%$ of that reduction can be attributed to total hardware costs (module, inverter, and hardware BOS), with module prices dropping $85 \%$ over that period. An additional $20 \%$ can be attributed to labor costs, which dropped $84 \%$ over the period. The final $22 \%$ is attributable to other soft costs, including PII, sales tax, overhead, and net profit. ${ }^{17}$ From 2019 to 2020 , there was a $2 \%$ reduction in the residential PV system cost benchmark.

\section{Comparing Multicrystalline and Monocrystalline PV Systems}

In this year's report, we model systems using monocrystalline PV modules, unlike previous editions of this report (Fu et al. 2018), for which we modeled multicrystalline PV modules. In the past few years, the U.S. market has had an increasing demand for monocrystalline modules; by 2020, there is not enough demand for multicrystalline modules to give an apples-to-apples comparison of U.S. spot pricing. Figure 18 compares Q1 2019 residential PV system pricing when using monocrystalline versus multicrystalline modules, and it shows the change in price of a residential PV system using monocrystalline modules between Q1 2019 and Q1 2020.

\footnotetext{
${ }^{17}$ Although the residential PV system model always assumes a 22-panel design for all years, the rated size of the system increases owing to improvements in efficiencies. Therefore, some of the cost reduction can be attributed to an increase in system size.
} 


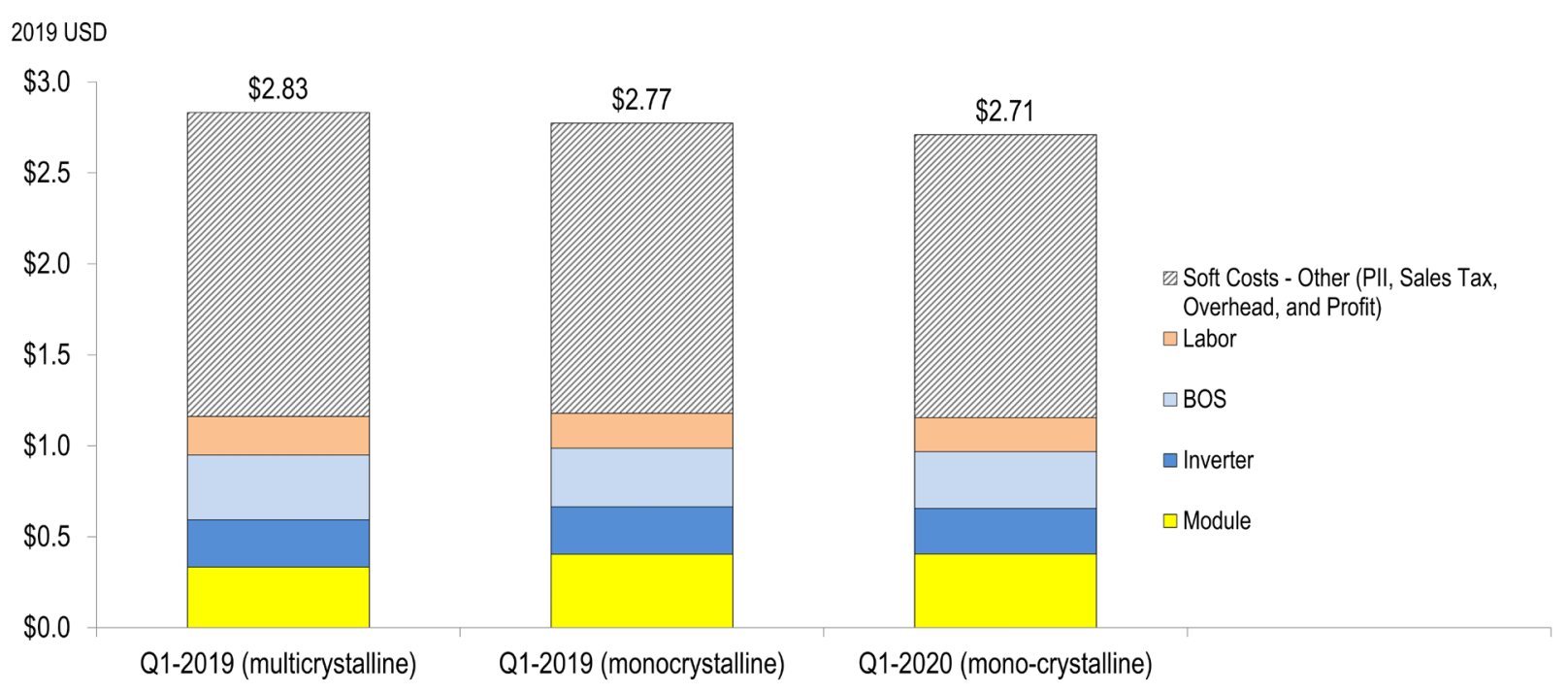

Figure 18. Q1 2019 cost for a residential multicrystalline PV system and Q1 2019 and Q1 2020 costs for a residential monocrystalline PV system

As shown in Figure 18, in Q1 2019 there was a \$0.06/W system price premium from using multicrystalline modules over monocrystalline modules for residential PV systems. The total system cost reductions achieved by increasing efficiency with monocrystalline modules outweighed the premium in monocrystalline module price. Residential PV systems using monocrystalline modules achieved a \$0.06/W (2\%) reduction in price from Q1 2019 to Q1 2020.

\subsection{Residential PV LCOE Historical Trends}

Assumptions for the residential PV LCOE benchmarks from 2010 to 2020 are summarized in Table 4. In addition to a 64\% reduction in installed cost from 2010 to 2020, O\&M costs declined $49 \%$, annual degradation declined $30 \%$, equity discount rate declined $32 \%$, debt interest rate declined 27\%, and debt fraction increased 57\%. 
Table 4. Residential PV: LCOE Assumptions, 2010-2020 (2019 USD/WDC)

\begin{tabular}{|c|c|c|c|c|c|c|c|c|c|c|c|}
\hline & 2010 & 2011 & 2012 & 2013 & 2014 & 2015 & 2016 & 2017 & 2018 & 2019 & 2020 \\
\hline \multicolumn{12}{|l|}{ Benchmark Report } \\
\hline Installed cost $(\$ / \mathrm{W})$ & 7.53 & 6.62 & 4.67 & 4.09 & 3.60 & 3.36 & 3.16 & 2.94 & 2.78 & 2.77 & 2.71 \\
\hline Inverter loading ratio & 1.10 & 1.11 & 1.12 & 1.13 & 1.13 & 1.14 & 1.15 & 1.15 & 1.15 & 1.15 & 1.15 \\
\hline \multicolumn{12}{|l|}{ Ongoing NREL Benchmarking } \\
\hline Annual degradation (\%) & 1.00 & 0.95 & 0.90 & 0.85 & 0.80 & 0.75 & 0.75 & 0.75 & 0.70 & 0.70 & 0.70 \\
\hline O\&M expenses $(\$ / k W-y r)$ & 56 & 49 & 42 & 36 & 31 & 26 & 25 & 25 & 22 & 27 & 29 \\
\hline Preinverter derate (\%) & 90.0 & 90.1 & 90.2 & 90.3 & 90.4 & 90.5 & 90.5 & 90.5 & 90.5 & 90.5 & 90.5 \\
\hline Inverter efficiency (\%) & 94.0 & 94.8 & 95.6 & 96.4 & 97.2 & 98.0 & 98.0 & 98.0 & 98.0 & 98.0 & 98.0 \\
\hline Inflation rate $(\%)$ & 2.5 & 2.5 & 2.5 & 2.5 & 2.5 & 2.5 & 2.5 & 2.5 & 2.5 & 2.5 & 2.5 \\
\hline \multicolumn{12}{|l|}{ Market Case } \\
\hline Equity discount rate (real) (\%) & 9.0 & 8.6 & 8.3 & 7.9 & 7.6 & 7.3 & 6.9 & 6.9 & 6.9 & 6.1 & 6.1 \\
\hline Debt interest rate (\%) & 5.5 & 5.4 & 5.3 & 5.2 & 5.0 & 4.9 & 4.8 & 4.8 & 4.8 & 4.0 & 4.0 \\
\hline Debt fraction (\%) & 34.2 & 35.2 & 36.1 & 37.1 & 38.1 & 39.0 & 40.0 & 40.0 & 40.0 & 53.7 & 53.7 \\
\hline \multicolumn{12}{|c|}{ Steady-State Financing (No ITC) } \\
\hline Equity discount rate (real) (\%) & - & - & - & - & - & - & - & - & - & - & 6.1 \\
\hline Debt interest rate (\%) & - & - & - & - & - & - & - & - & - & - & 5.0 \\
\hline Debt fraction (\%) & - & - & - & - & - & - & - & - & - & - & 71.8 \\
\hline
\end{tabular}

All 2010-2018 data are from Fu, Feldman, and Margolis (2018), and they are adjusted for inflation. Residential PV system LCOE assumes:

(1) System lifetime of 30 years

(8) Module tilt angle of 25 degrees, and an azimuth of 180 degrees

(2) Federal tax rate of $21 \%$

(9) Debt with a term of 18 years

(3) State tax rate of $6 \%$

(4) Modified Accelerated Cost Recovery System (MACRS) depreciation schedule

(5) No state or local subsidies

(10) $\$ 1.1$ million of upfront financial transaction costs for a $\$ 100$ million TPO transaction of a pool of residential projects

(11) 2019 and 2020 financial assumptions from Feldman, Bolinger, and Schwabe (2020).

(6) A working capital and debt service reserve account for six months of operating costs and debt payments (earning an interest rate of $1.75 \%$ )

7) Three-month construction loan, with an interest rate of $4 \%$ and a fee of $1 \%$ of the cost of the system 
Using these assumptions, we calculate the residential PV LCOE — with and without the 30\% federal ITC - for a high solar resource (capacity factor [CF]: 21.6\%), medium solar resource (CF: 17.6\%), and low solar resource (CF: 16.4\%) (Figure 19). ${ }^{18}$ From 2010 to 2020, residential PV LCOE declined 74\% (1\% between 2019 and 2020), resulting in an unsubsidized LCOE of $\$ 0.11-\$ 0.14 / \mathrm{kWh}(\$ 0.07-\$ 0.09 / \mathrm{kWh}$ when including the federal ITC). This reduction is $93 \%$ toward achieving SETO's 2020 residential PV LCOE goal from the residential PV system price when the goal was announced in $2010 .{ }^{19} \mathrm{We}$ also calculate PV LCOE without the ITC using steady-state financing assumptions. Under these assumptions, unsubsidized residential PV LCOE ranges from $\$ 0.10-\$ 0.14 / \mathrm{kWh}$ in Q1 2020.

\section{SETO Goal (in 2019 USD): \\ LCOE $=10.6$ cents $/ \mathrm{kWh}$ without ITC. 2030 SETO Goal \\ (in 2019 USD): LCOE $=5.3$ cents/kWh without ITC}

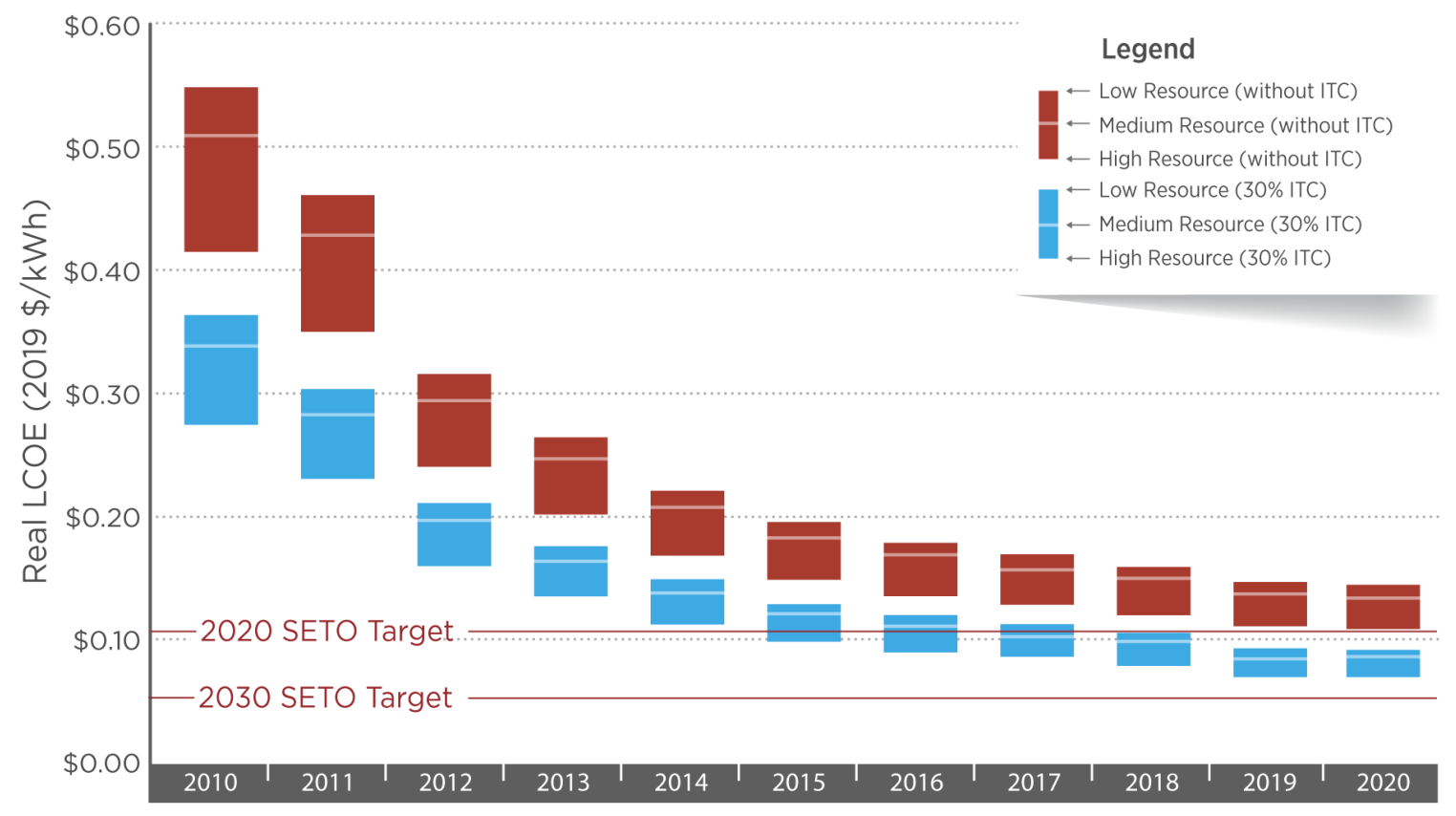

Figure 19. LCOE for residential PV systems, by region, with and without ITC, 2010-2020

We updated our methods and model this year; 2019 and 2020 LCOEs are higher than they would have been using previous models. Appendix A provides a detailed discussion of the changes made to the models between the previous version (Fu, Feldman, and Margolis 2018) and this year's version. LCOE is calculated for each scenario under a range of $\mathrm{CFs}$, but all other values remain the same.

\footnotetext{
${ }^{18} \mathrm{CFs}$ are calculated based on Phoenix, AZ (high solar resource), Kansas City, MO (medium solar resource), and New York, NY (low solar resource).

${ }^{19}$ In 2019 USD, the 2020 SETO target is $\$ 0.106 / \mathrm{kWh}$, and the residential LCOE in a medium resource area (without the ITC) is $\$ 0.509 / \mathrm{kWh}$ in 2010 and $\$ 0.135 / \mathrm{kWh}$ in 2020 ; see Appendix B. Progress toward the SETO target is calculated as follows: $(0.509-0.135) /(0.509-0.106)=93 \%$.
} 


\section{Commercial PV Model}

This section describes our commercial PV model's structure, inputs, and assumptions (Section 4.1) and output (4.2) as well as trends in historical PV price (4.3) and LCOE (4.4).

\subsection{Commercial Model Structure, Inputs, and Assumptions}

We model both a 200-kW, 1,000-volt DC ( $\left.\mathrm{V}_{\mathrm{DC}}\right)$, commercial-scale flat-roof system using a ballasted racking solution on a membrane roof, ${ }^{20}$ and a $500-\mathrm{kW}, 1,000-\mathrm{V}_{\mathrm{DC}}$ commercial-scale fixed-tilt ground-mount system using driven-pile foundations; the ground-mount system is larger because U.S. ground-mount systems are larger than rooftop systems on average. Owing to the adoption of the 2017 and 2020 NEC in many states, three-phase string inverter, power optimizer, and microinverter options are each modeled individually for the commercial rooftop model, and the "mixed" case applies their market shares (45\%, 39\%, and 16\%, respectively) as weightings. Because the 2017 NEC only requires rapid shutdown at the module level for rooftop applications, the commercial ground-mount system only models three-phase string inverters. Both models use monocrystalline 19.5\%-efficient modules from a Tier 1 supplier.

We also model a range of system sizes, from $100 \mathrm{~kW}$ to $2 \mathrm{MW}$. Figure 20 presents a schematic of our commercial-scale system cost model. Table 5 presents the detailed modeling inputs and assumptions. We separate our cost estimate into EPC and project-development functions.

Although some firms engage in both activities in an integrated manner, and potentially achieve lower cost and pricing by reducing the total margin across functions, we believe the distinction can help separate and highlight the specific cost trends and drivers associated with each function.

\footnotetext{
${ }^{20}$ A penetrating PV mounting system can have higher energy yield (in kilowatt-hours per kilowatt) than a ballasted racking solution owing to wider tilt-angle range allowance. However, we do not model this system type, because its market share has declined owing to the additional flashing and sealing work required, roof warranty issues, and the difficulty of replacing such systems.
} 


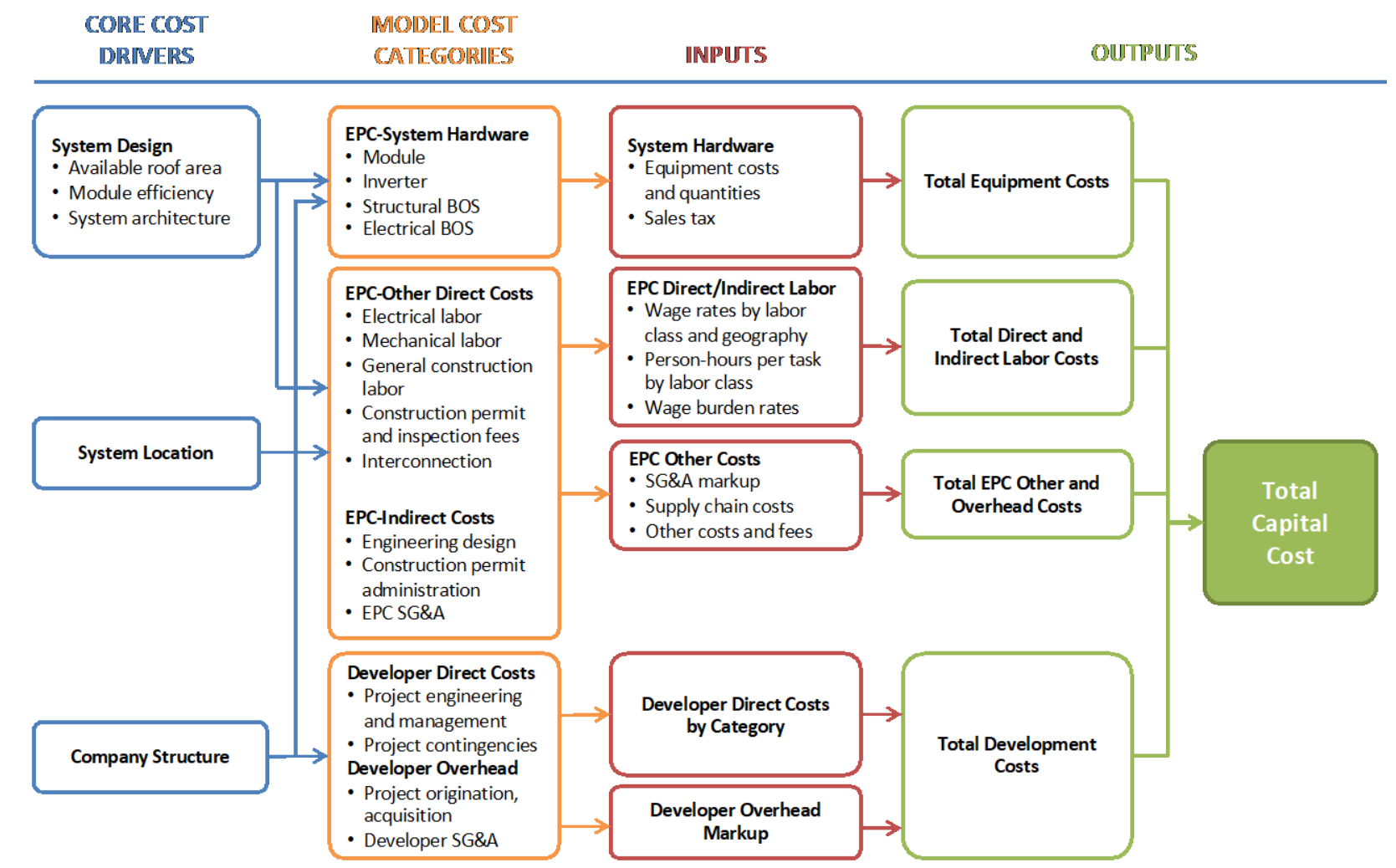

Figure 20. Commercial PV: Model structure

SG\&A = selling, general, and administrative

Table 5. Commercial PV: Modeling Inputs and Assumptions

\begin{tabular}{|c|c|c|c|}
\hline Category & Modeled Value & Description & Sources \\
\hline System size & $\begin{array}{l}200 \mathrm{~kW} \text { (rooftop) and } \\
500 \mathrm{~kW} \text { (ground- } \\
\text { mount); range (100 } \\
\text { kW-2 MW) }\end{array}$ & $\begin{array}{l}\text { Average installed size } \\
\text { per system }\end{array}$ & $\begin{array}{l}\text { Barbose and } \\
\text { Darghouth } 2019\end{array}$ \\
\hline $\begin{array}{l}\text { Module } \\
\text { efficiency }\end{array}$ & $19.5 \%$ & $\begin{array}{l}\text { Average monocrystalline } \\
\text { module efficiency }\end{array}$ & CA NEM 2020 \\
\hline Module price & $\$ 0.41 / \mathrm{W}_{\mathrm{DC}}$ & $\begin{array}{l}\text { Ex-factory gate (first } \\
\text { buyer) ASP, Tier } 1 \\
\text { monocrystalline modules }\end{array}$ & $\begin{array}{l}\text { Wood Mackenzie } \\
\text { and SEIA } 2020\end{array}$ \\
\hline \multirow[t]{3}{*}{ Inverter price } & $\begin{array}{l}\text { Three-phase string } \\
\text { inverter: } \$ 0.07 / \mathrm{WDC}_{\mathrm{DC}}\end{array}$ & \multirow{3}{*}{$\begin{array}{l}\text { Ex-factory gate prices } \\
\text { (first buyer) ASP, Tier } 1 \\
\text { inverters }\end{array}$} & \multirow{3}{*}{$\begin{array}{l}\text { Wood Mackenzie 2020; } \\
\text { Wood Mackenzie and } \\
\text { SEIA } 2020\end{array}$} \\
\hline & $\begin{array}{l}\text { DC power optimizer } \\
\text { three-phase string } \\
\text { inverter: } \$ 0.12 / W_{D C} \\
\text { (rooftop only) }\end{array}$ & & \\
\hline & $\begin{array}{l}\text { Microinverter: } \\
\$ 0.29 / W_{D C} \text { (rooftop } \\
\text { only) }\end{array}$ & & \\
\hline
\end{tabular}




\begin{tabular}{|c|c|c|c|}
\hline Category & Modeled Value & Description & Sources \\
\hline $\begin{array}{l}\text { Structural } \\
\text { components } \\
\text { (racking) }\end{array}$ & $\begin{array}{l}\$ 0.11-\$ 0.17 / \mathrm{WDC}_{\mathrm{DC}} \\
\text { assumes national } \\
\text { average wind and snow } \\
\text { loadinga; varies by } \\
\text { racking type (ground- } \\
\text { mount versus rooftop } \\
\text { ballasted) }\end{array}$ & $\begin{array}{l}\text { Ex-factory gate prices; } \\
\text { flat-roof ballasted } \\
\text { racking system or fixed- } \\
\text { tilt ground-mount racking } \\
\text { system }\end{array}$ & $\begin{array}{l}\text { MEPS 2019; } \\
\text { model assumptions; } \\
\text { NREL } 2019\end{array}$ \\
\hline $\begin{array}{l}\text { Electrical } \\
\text { components }\end{array}$ & $\$ 0.13-\$ 0.24 / W_{D C}$ & $\begin{array}{l}\text { Conductors, conduit and } \\
\text { fittings, transition boxes, } \\
\text { switchgear, panel } \\
\text { boards, and other parts }\end{array}$ & $\begin{array}{l}\text { Model assumptions; } \\
\text { NREL 2020; RSMeans } 2017\end{array}$ \\
\hline $\begin{array}{l}\text { EPC } \\
\text { overhead } \\
\text { (percentage } \\
\text { of equipment } \\
\text { costs) }\end{array}$ & $13 \%$ & $\begin{array}{l}\text { Costs and fees } \\
\text { associated with EPC } \\
\text { overhead, inventory, } \\
\text { shipping, and handling }\end{array}$ & NREL 2020 \\
\hline Sales tax & National average: $5 \%$ & $\begin{array}{l}\text { Sales tax on equipment } \\
\text { costs }\end{array}$ & RSMeans 2017 \\
\hline \multirow{2}{*}{$\begin{array}{l}\text { Direct } \\
\text { installation } \\
\text { labor }\end{array}$} & $\begin{array}{l}\text { Electrician: } \$ 27.47 \text { per } \\
\text { hour }\end{array}$ & \multirow{2}{*}{$\begin{array}{l}\text { Modeled labor rate } \\
\text { assumes national } \\
\text { average nonunionized } \\
\text { labor rates }\end{array}$} & \multirow[t]{2}{*}{ BLS 2019; NREL 2020} \\
\hline & $\begin{array}{l}\text { Laborer: } \$ 18.17 \\
\text { per hour }\end{array}$ & & \\
\hline $\begin{array}{l}\text { Burden rates } \\
\text { (percentage } \\
\text { of direct } \\
\text { labor) }\end{array}$ & $\begin{array}{l}\text { Total nationwide } \\
\text { average: } 18 \%\end{array}$ & $\begin{array}{l}\text { Workers compensation, } \\
\text { federal and state } \\
\text { unemployment } \\
\text { insurance, FICA, } \\
\text { builders' risk, public } \\
\text { liability }\end{array}$ & RSMeans 2017 \\
\hline PII & $\$ 0.11 / \mathrm{W}_{\mathrm{DC}}$ & $\begin{array}{l}\text { For construction permits } \\
\text { fee, interconnection } \\
\text { study fees for existing } \\
\text { substation, testing, and } \\
\text { commissioning }\end{array}$ & NREL 2020 \\
\hline $\begin{array}{l}\text { Developer } \\
\text { overhead }\end{array}$ & $\begin{array}{l}\$ 0.30-\$ 0.36 / \mathrm{W} \\
\text { Varies by system size } \\
\text { (30\% developer } \\
\text { overhead) }\end{array}$ & $\begin{array}{l}\text { Includes overhead } \\
\text { expenses such as } \\
\text { payroll, facilities, travel, } \\
\text { legal fees, } \\
\text { administrative, business } \\
\text { development, finance, } \\
\text { and other corporate } \\
\text { functions }\end{array}$ & $\begin{array}{l}\text { Model assumptions; } \\
\text { NREL } 2020\end{array}$ \\
\hline Contingency & $4 \%$ & $\begin{array}{l}\text { Estimated as markup on } \\
\text { EPC cost; value } \\
\text { represents actual cost } \\
\text { overruns above } \\
\text { estimated cost }\end{array}$ & NREL 2020 \\
\hline
\end{tabular}




\begin{tabular}{llll}
\hline Category & Modeled Value & Description & Sources \\
\hline Profit & $7 \%$ & Applies a fixed & NREL 2020 \\
& percentage margin to all & \\
& costs, including & \\
& hardware, installation & \\
& labor, EPC overhead, \\
& and developer overhead & \\
\hline
\end{tabular}

\begin{abstract}
a Racking companies currently meet the national standard, so there is not as much differentiation by state in the market within rooftop systems. The ground-mount racking system requires more material, equipment, and labor compared than the ballasted racking system. However, installation of ground-mount PV systems at utility scale helps reduce the BOS cost of these systems owing to economies of scale.
\end{abstract}

\title{
4.2 Commercial Model Output
}

Figure 21 presents the U.S. national benchmarks from our commercial PV models. We model different system sizes because of the wide scope of the commercial sector, which comprises a diverse customer base occupying a variety of building and property sizes. Economies of scaledriven by hardware, labor, and related markups - are evident here. As system sizes increase, the per-watt cost to build systems decreases. As shown in Figure 21 and Figure 22, commercial rooftop applications have lower costs than commercial ground-mount systems for several smaller system sizes. However, the difference in price decreases as system size increases, and groundmount systems have lower costs for system sizes of 1 and $2 \mathrm{MW}$. Compared with rooftop systems, ground-mount applications have higher material, equipment, and labor costs associated with pile-driven mounting. As PV system size increases, the per-watt cost of pile-driven mounting is significantly reduced through economies of scale. Ground-mount commercial PV systems also benefit from lower inverter costs owing to the rapid shutdown requirements for commercial rooftop systems.

Figure 23 and Figure 24 show sensitivity analyses for the 200-kW rooftop system and 500-kW ground-mount system, with cost categories that vary by location and hardware specification. For the rooftop system, inverter type has the largest impact on installed system cost. For the groundmount system, material location factor and equipment location factor have the largest impacts. 


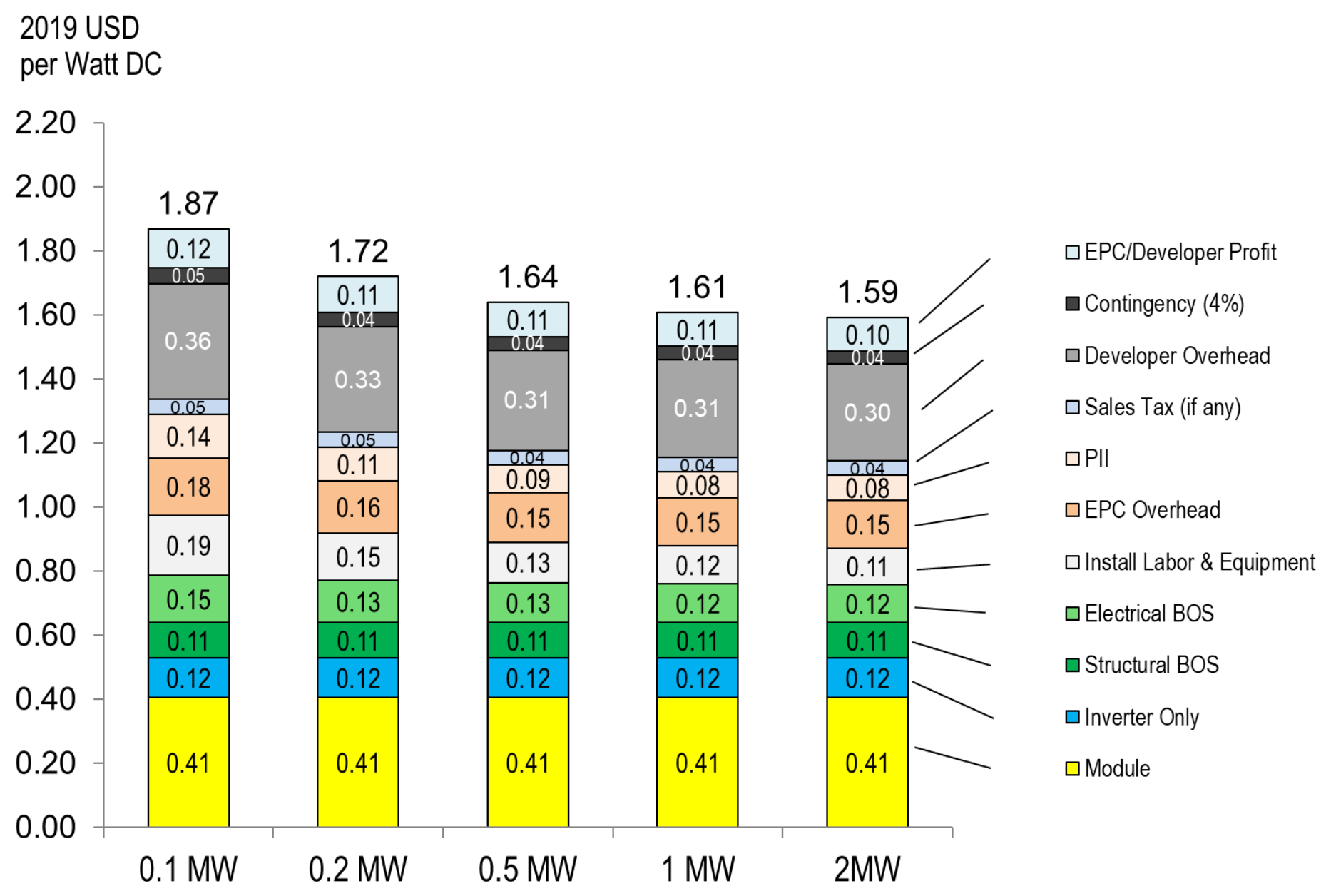

Figure 21. Q1 2020 U.S. benchmark: Commercial rooftop PV system cost (2019 USD/WDC) 


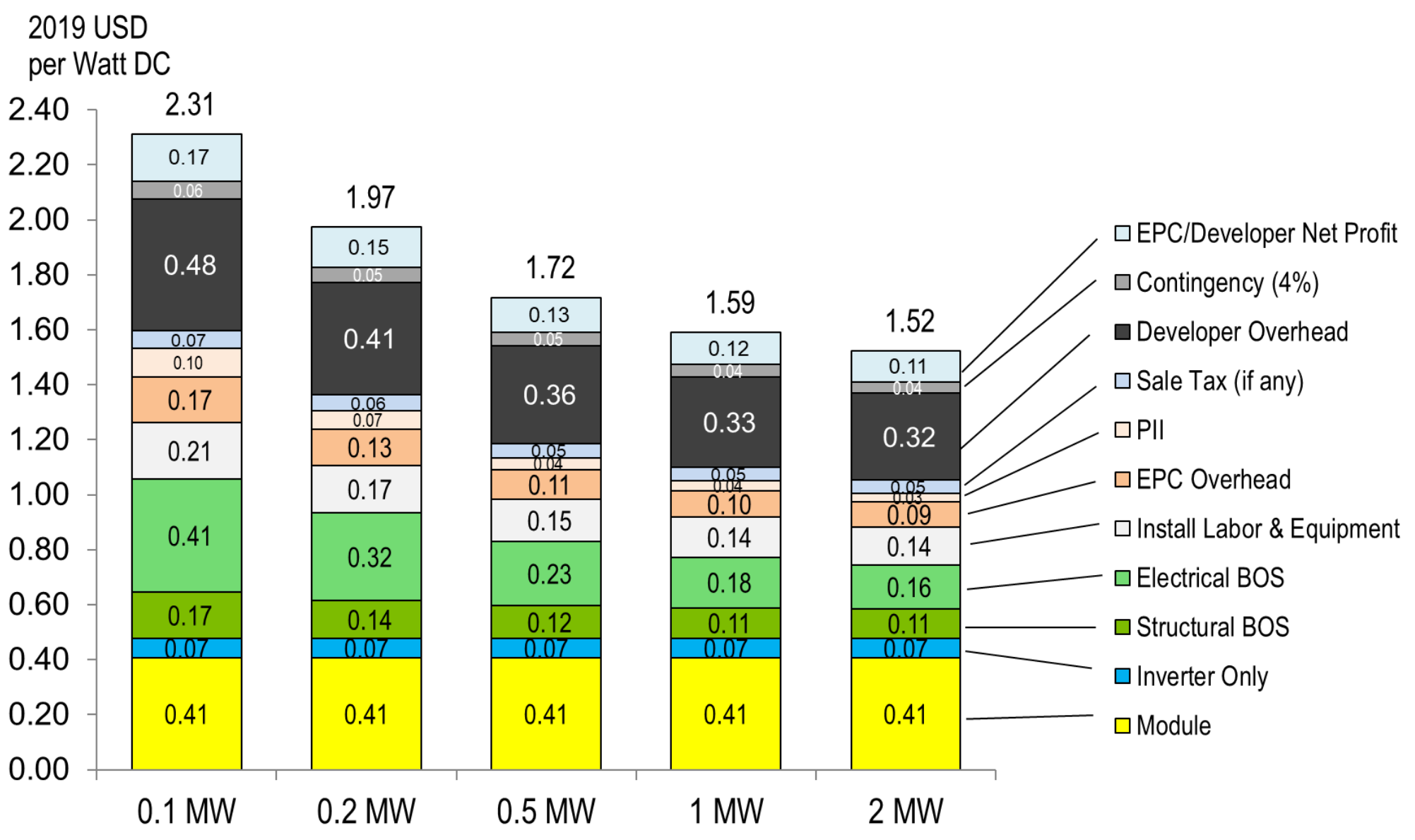

Figure 22. Q1 2020 U.S. benchmark: Commercial ground-mount PV system cost (2019 USD/W 


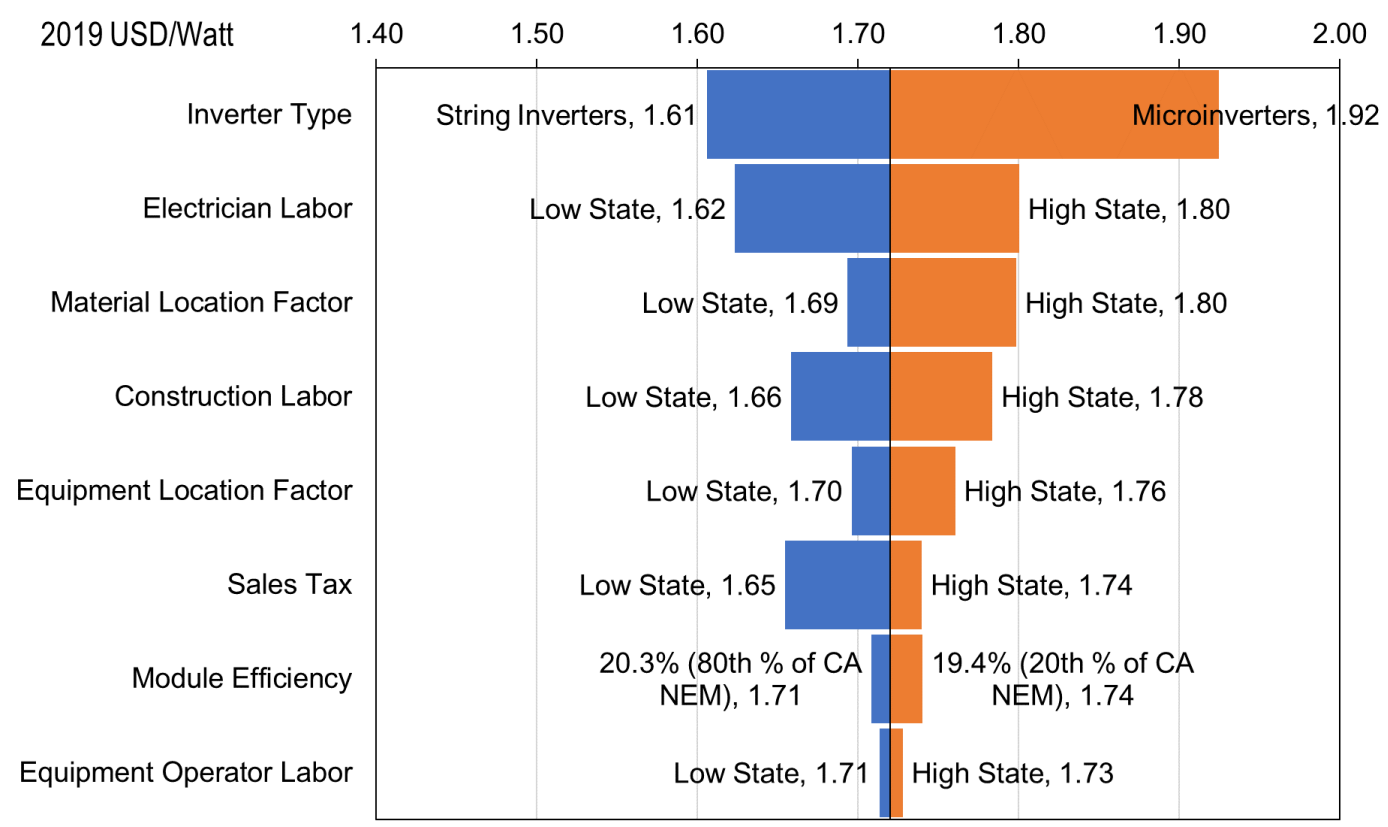

Figure 23. Sensitivity analysis for the Q1 2020 benchmark: 200-kW rooftop commercial PV system cost (2019 USD/W DC)

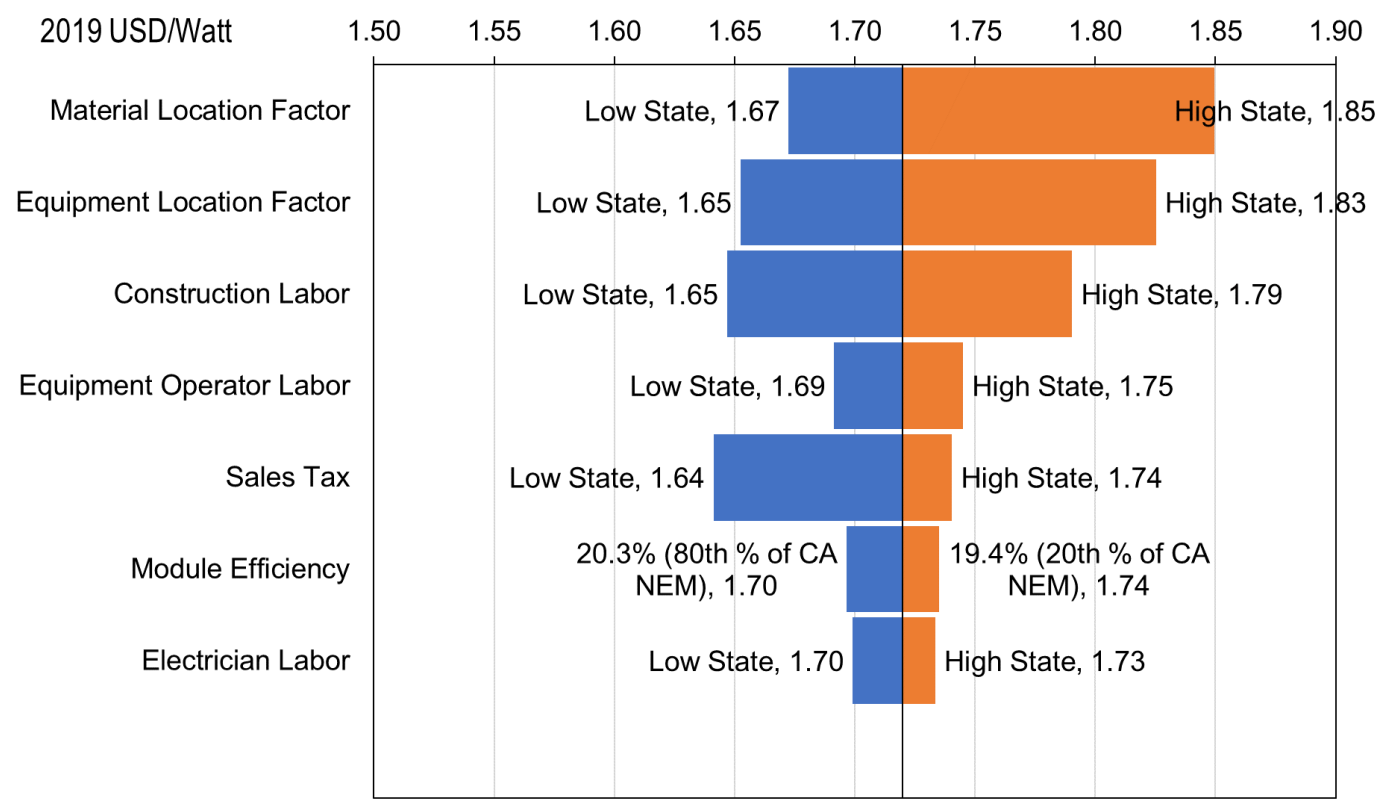

Figure 24. Sensitivity analysis for the Q1 2020 benchmark: 500-kW commercial ground-mount PV system cost (2019 USD/W 


\subsection{Commercial Rooftop PV Price Benchmark Historical Trends}

The current version of our commercial cost model makes a few significant changes from the version used in our Q1 2018 benchmark report (Fu, Feldman, and Margolis 2018). To better distinguish the historical cost trends from the changes to our cost models, we also calculate Q1 2019 and Q1 2020 PV benchmarks using the Q1 2018 version. Appendix A provides a detailed discussion of the changes made to the models between the previous report (Fu, Feldman, and Margolis 2018) and this year's report. Figure 25 summarizes the reduction in commercial PV system cost benchmarks between 2010 and 2020. The "Additional Costs from Model Updates" category represents the difference between modeled results calculated using the current model versus the previous model. Using the previous cost model, the Q1 2019 and Q1 2020 benchmarks are calculated to be $\$ 1.71 / \mathrm{W}_{\mathrm{DC}}$ and $\$ 1.64 / \mathrm{W}_{\mathrm{DC}}$, respectively. Figure 25 shows a $69 \%$ reduction in commercial PV system cost benchmarks between 2010 and $2020 .{ }^{21}$

Approximately $78 \%$ of that reduction can be attributed to total hardware costs (module, inverter, and hardware BOS), and module prices dropped $85 \%$ over that period. The final $22 \%$ is attributable to labor and soft costs, including PII, sales tax, overhead, and net profit. From 2019 to 2020 , there was a $2.4 \%$ reduction in the commercial rooftop PV system cost benchmark, largely driven by reductions in inverter and BOS hardware costs.

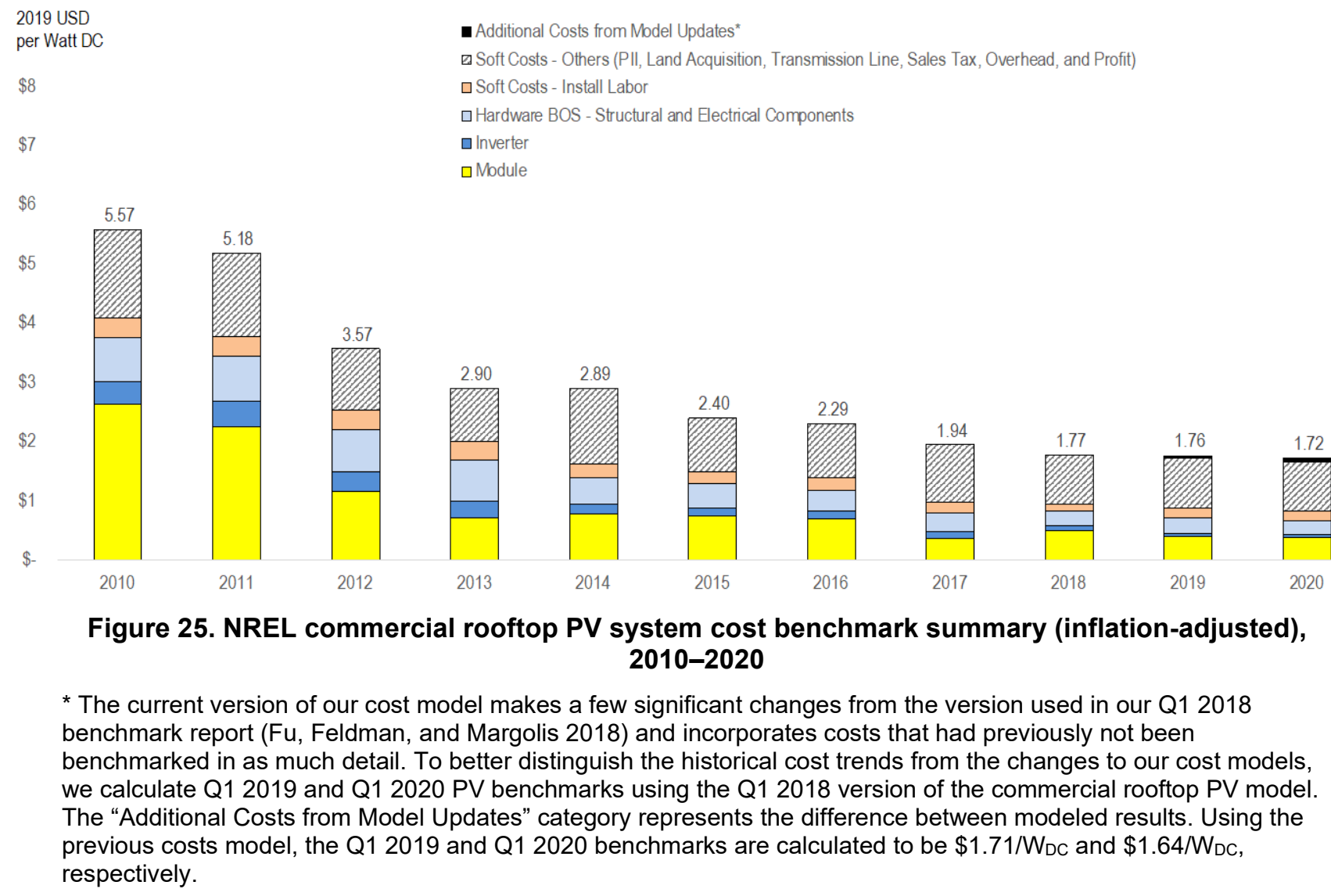

\footnotetext{
${ }^{21}$ Each year's PV system cost benchmark corresponds to the NREL benchmark calculated in Q4 of the previous year or Q1 of the current year (e.g., $2010=$ Q4 2009; $2017=$ Q1 2017).
} 


\section{Comparing Multicrystalline and Monocrystalline PV Systems}

For the same reasons described in Section 3.7.1, we compare commercial rooftop system pricing using monocrystalline and multicrystalline PV modules. Figure 26 compares Q1 2019 system pricing between commercial rooftop systems using the different module types, and it shows the change in price of a commercial rooftop PV system using monocrystalline PV modules between Q1 2019 and Q1 2020.

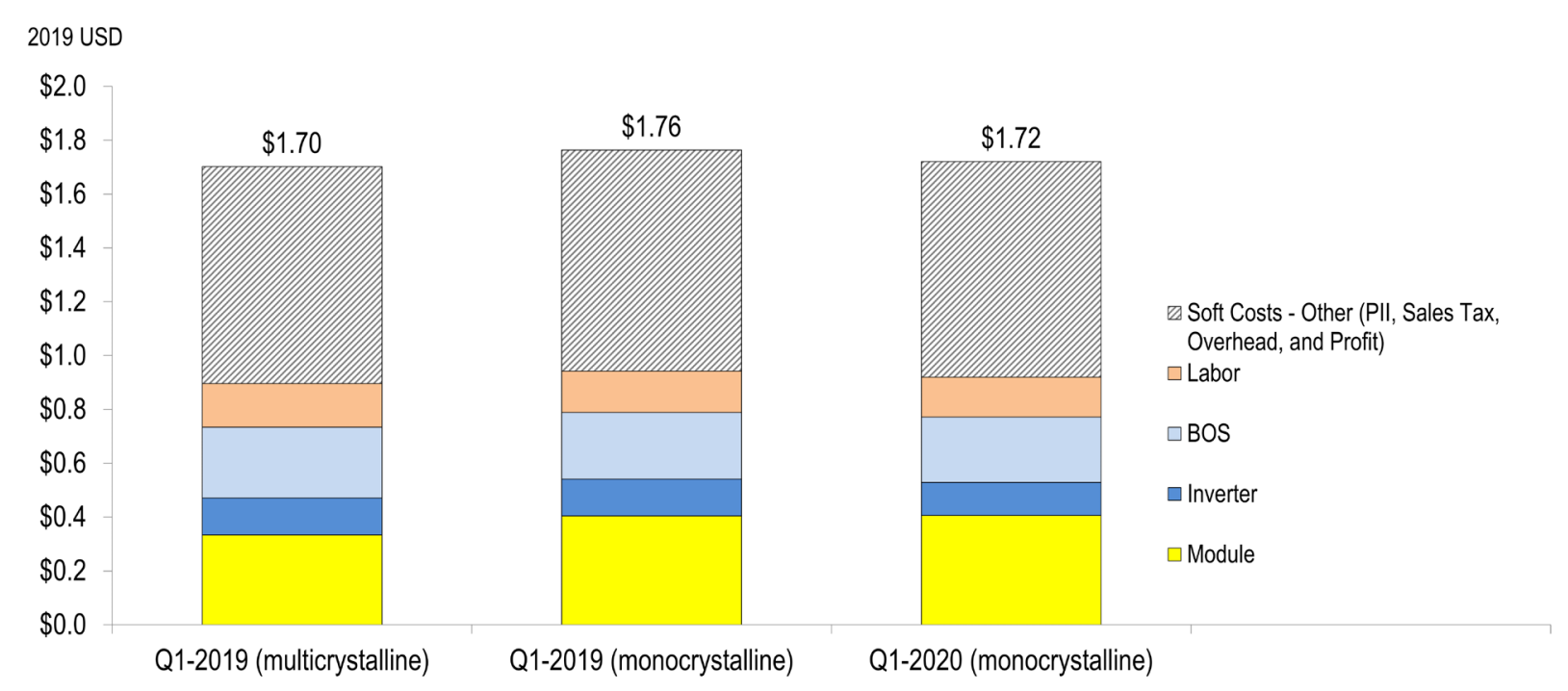

Figure 26. Q1 2019 cost for a commercial rooftop multicrystalline PV system and Q1 2019 and Q1 2020 costs for a commercial rooftop monocrystalline PV system

As shown in Figure 26, in Q1 2019 there was a \$0.06/W system price premium for using monocrystalline PV modules over multicrystalline PV modules in commercial rooftop PV systems. The system cost reductions achieved by increased monocrystalline module efficiency were counterbalanced by the higher module price. Commercial rooftop PV systems using monocrystalline modules achieved a \$0.04/W (2.4\%) reduction in price from Q1 2019 to Q1 2020 .

\subsection{Commercial PV LCOE Historical Trends}

Assumptions for the commercial PV LCOE benchmarks from 2010 to 2020 are summarized in Table 6 . In addition to the $69 \%$ reduction in installed cost for commercial rooftop PV from 2010 to 2020 , O\&M costs declined $46 \%$, annual degradation declined $30 \%$, equity discount rate declined $32 \%$, debt interest rate declined $27 \%$, and debt fraction increased $57 \%$. 
Table 6. Commercial PV: LCOE Assumptions, 2010-2020 (2019 USD/WDC)

\begin{tabular}{|c|c|c|c|c|c|c|c|c|c|c|c|}
\hline & 2010 & 2011 & 2012 & 2013 & 2014 & 2015 & 2016 & 2017 & 2018 & 2019 & 2020 \\
\hline \multicolumn{12}{|l|}{ Rooftop (200 kW) } \\
\hline Installed cost $(\$ / \mathrm{W})$ & 5.57 & 5.18 & 3.57 & 2.90 & 2.89 & 2.40 & 2.29 & 1.94 & 1.77 & 1.76 & 1.72 \\
\hline Inverter loading ratio & 1.10 & 1.11 & 1.12 & 1.13 & 1.13 & 1.14 & 1.15 & 1.15 & 1.15 & 1.15 & 1.15 \\
\hline Annual degradation (\%) & 1.00 & 0.95 & 0.90 & 0.85 & 0.80 & 0.75 & 0.75 & 0.75 & 0.70 & 0.70 & 0.70 \\
\hline O\&M expenses (\$/kW-yr) & 35 & 32 & 29 & 26 & 23 & 20 & 19 & 19 & 18 & 19 & 19 \\
\hline Preinverter derate $(\%)$ & 90.5 & 90.5 & 90.5 & 90.5 & 90.5 & 90.5 & 90.5 & 90.5 & 90.5 & 90.5 & 90.5 \\
\hline Inverter efficiency (\%) & 95.0 & 95.6 & 96.2 & 96.8 & 97.4 & 98.0 & 98.0 & 98.0 & 98.0 & 98.0 & 98.0 \\
\hline \multicolumn{12}{|l|}{ Ground-Mount (500 kW) } \\
\hline Installed cost (\$/W) & - & - & - & - & - & - & - & - & - & - & 1.72 \\
\hline Inverter loading ratio & - & - & - & - & - & - & - & 一 & - & 一 & 1.11 \\
\hline Annual degradation (\%) & - & - & - & - & - & - & - & - & - & - & 0.70 \\
\hline O\&M expenses (\$/kw-yr) & - & - & - & 一 & - & - & - & - & - & - & 18.71 \\
\hline Preinverter derate $(\%)$ & - & - & - & - & - & - & - & - & - & - & 90.5 \\
\hline Inverter efficiency (\%) & - & 一 & - & 一 & - & - & - & 一 & - & 一 & 98.0 \\
\hline \multicolumn{12}{|l|}{ Financing Assumptions } \\
\hline Inflation rate (\%) & 2.5 & 2.5 & 2.5 & 2.5 & 2.5 & 2.5 & 2.5 & 2.5 & 2.5 & 2.5 & 2.5 \\
\hline \multicolumn{12}{|l|}{ Market Case } \\
\hline Equity discount rate (real) (\%) & 9.0 & 8.6 & 8.3 & 7.9 & 7.6 & 7.3 & 6.9 & 6.9 & 6.9 & 6.1 & 6.1 \\
\hline Debt interest rate (\%) & 5.5 & 5.4 & 5.3 & 5.2 & 5.0 & 4.9 & 4.8 & 4.8 & 4.8 & 4.0 & 4.0 \\
\hline Debt fraction (\%) & 34.2 & 35.2 & 36.1 & 37.1 & 38.1 & 39.0 & 40.0 & 40.0 & 40.0 & 53.8 & 53.8 \\
\hline \multicolumn{12}{|l|}{ Steady-State financing } \\
\hline Equity discount rate (real) (\%) & - & - & - & - & - & - & - & - & - & - & 6.1 \\
\hline Debt interest rate (\%) & - & - & - & - & - & - & - & - & - & - & 5.0 \\
\hline Debt fraction (\%) & - & - & - & - & - & - & - & - & - & - & 71.8 \\
\hline
\end{tabular}

All 2010-2018 data are from Fu, Feldman, and Margolis (2018), and they are adjusted for inflation. Commercial PV system LCOE assumes:

(1) System lifetime of 30 years 
(2) Federal tax rate of $21 \%$

(3) Sate tax rate of $6 \%$

(4) MACRS depreciation schedule

(5) No state or local subsidies

(6) A working capital and debt service reserve account for six months of operating costs and debt payments (earning an interest rate of 1.75\%)

(7) Six-month construction loan, with an interest rate of $4 \%$ and a fee of $1 \%$ of the cost of the system

(8) Module tilt angle of 10 degrees and an azimuth of 180 degrees

(9) Debt with a term of 18 years

(10) $\$ 1.1$ million of upfront financial transaction costs for a $\$ 100$ million TPO transaction of a pool of commercial projects

(11) 2019 and 2020 financial assumptions from Feldman, Bolinger, and Schwabe (2020). 
Using these assumptions, we calculate the commercial PV LCOE - with and without the 30\% federal ITC - for a high solar resource (Phoenix, CF: 20.4\%), medium solar resource (Kansas City, CF: 16.4\%), and low solar resource (New York City, CF: 15.3\%) (Figure 27). From 2010 to 2020, commercial rooftop PV LCOE declined 77\% (3\% between 2019 and 2020), resulting in an unsubsidized LCOE of $\$ 0.08-\$ 0.10 / \mathrm{kWh}(\$ 0.05-\$ 0.07 / \mathrm{kWh}$ when including the federal ITC). This reduction is 97\% toward achieving SETO's 2020 commercial PV LCOE goal from the commercial system price when the goal was announced in $2010 .{ }^{22}$ Commercial groundmount PV systems, which we began benchmarking this year, are calculated to have a 2020 unsubsidized LCOE of $\$ 0.07-\$ 0.09 / \mathrm{kWh}(\$ 0.05-\$ 0.06 / \mathrm{kWh}$ when including the federal ITC). We also calculate PV LCOE without the ITC using steady-state financing assumptions. Under these assumptions, the commercial rooftop PV LCOE ranges from $\$ 0.07-\$ 0.10 / \mathrm{kWh}$, and the commercial ground-mount PV LCOE ranges from \$0.07-\$0.10/kWh in Q1 2020.

\section{SETO Goal (in 2019 USD): \\ LCOE $=8.2$ cents $/ \mathrm{kWh}$ without ITC. 2030 SETO Goal (in 2019 USD): LCOE $=4.3$ cents $/ \mathrm{kWh}$ without ITC}

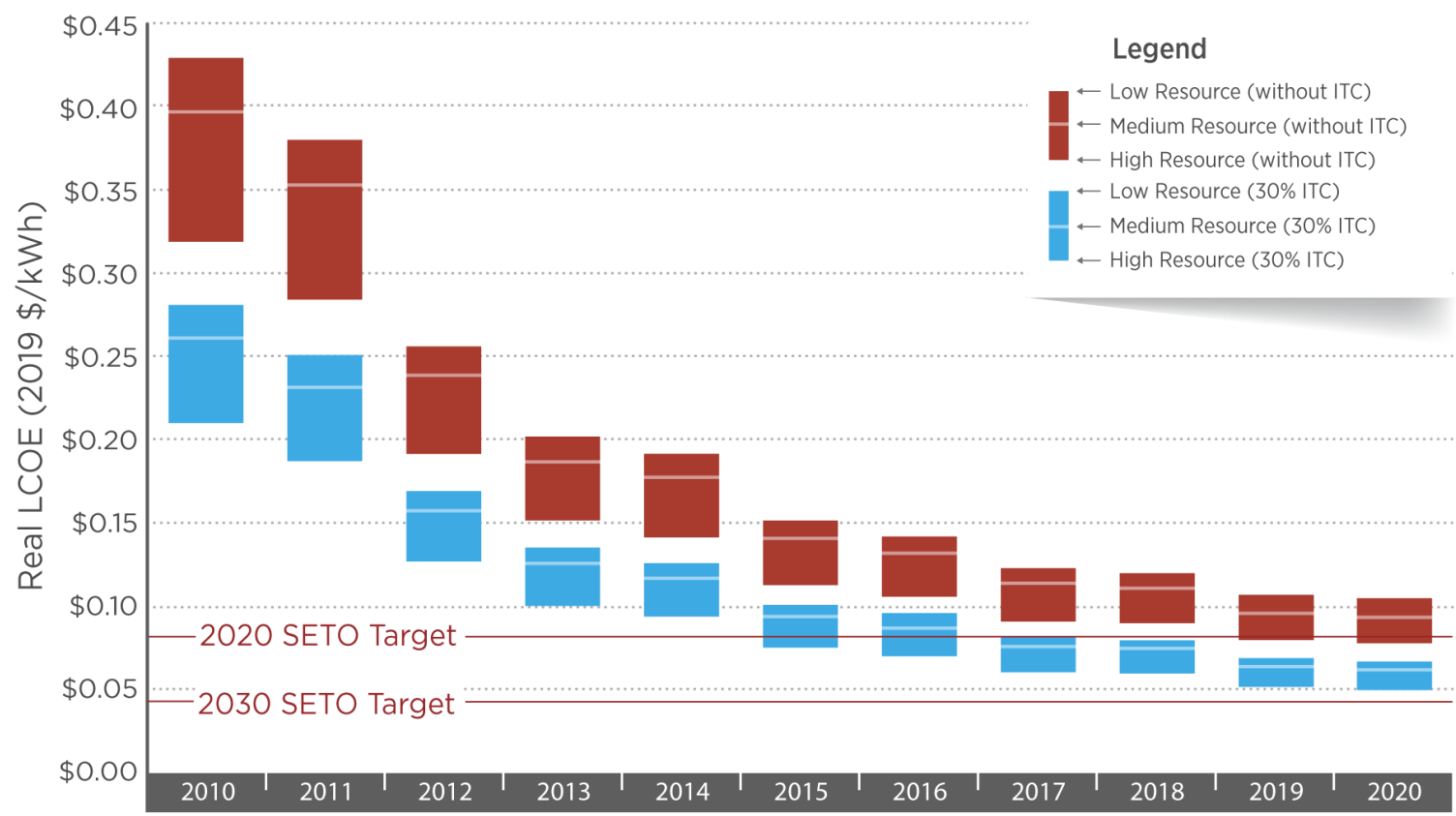

Figure 27. LCOE for commercial rooftop PV systems, by region, with and without ITC, 2010-2020

We updated our methods and model this year; 2019 and 2020 LCOEs are higher than they would have been using previous models. Appendix A provides a detailed discussion of the changes made to the models between the previous version (Fu, Feldman, and Margolis 2018) and this year's version. LCOE is calculated for each scenario under a range of CFs, but all other values remain the same.

\footnotetext{
${ }^{22}$ In 2019 USD, the 2020 SETO target is $\$ 0.082 / \mathrm{kWh}$, and the commercial LCOE in Kansas City (without the ITC) is $\$ 0.397 / \mathrm{kWh}$ in 2010 and $\$ 0.093 / \mathrm{kWh}$ in 2020 ; see Appendix B. Progress toward the SETO target is calculated as follows: $(0.397-0.093) /(0.397-0.082)=97 \%$.
} 


\section{Utility-Scale PV Model}

This section describes our utility-scale PV model's structure, inputs, and assumptions (Section 5.1) and output (5.2) as well as trends in historical PV price (5.3) and LCOE (5.4).

\subsection{Utility-Scale Model Structure, Inputs, and Assumptions}

We model a baseline 100-MW, 1,500-V $\mathrm{V}_{\mathrm{DC}}$ utility-scale system using 72-cell, monocrystalline 19.5\%-efficient modules from a Tier 1 supplier and three-phase central inverters. We model both fixed-tilt and one-axis tracking on ground-mounted racking systems using driven-pile foundations. In addition, we separate our cost estimates into EPC and project-development functions. Although some firms engage in both activities in an integrated manner, we believe the distinction can help separate and highlight the specific cost trends and drivers associated with each function. We also model a range of system sizes, from $5 \mathrm{MW}$ to $100 \mathrm{MW}$. Figure 28 presents a schematic of our utility-scale system cost model, and Table 7 details its assumptions and inputs.

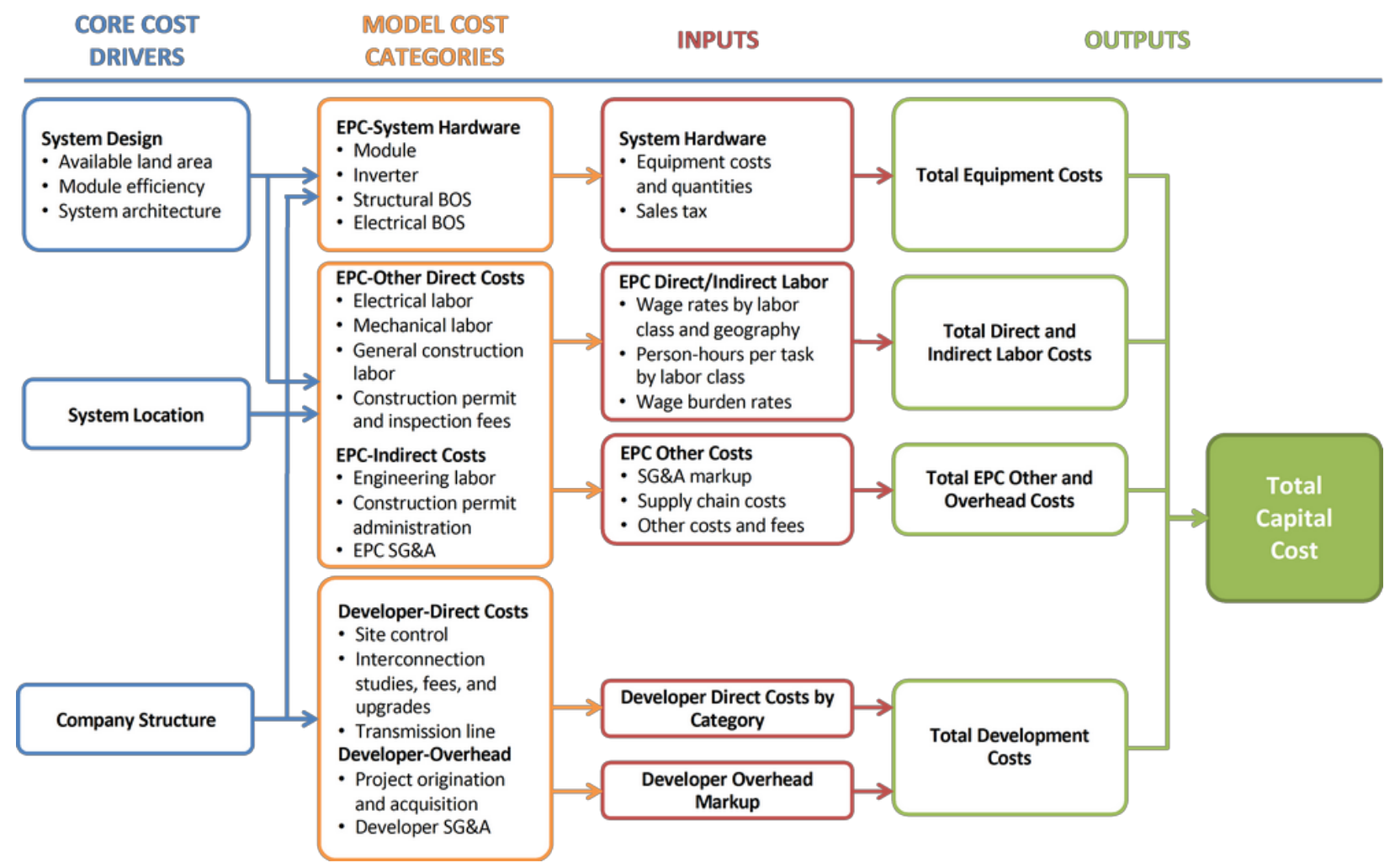

Figure 28. Utility-scale PV: Model structure 
Table 7. Utility-Scale PV: Modeling Inputs and Assumptions

\begin{tabular}{|c|c|c|c|}
\hline Category & Modeled Value & Description & Sources \\
\hline System size & $\begin{array}{l}100 \mathrm{MW} \text {; range: } \\
5 \mathrm{MW}-100 \mathrm{MW}\end{array}$ & A large utility-scale system capacity & Model assumption \\
\hline $\begin{array}{l}\text { Module } \\
\text { efficiency }\end{array}$ & $19.5 \%$ & $\begin{array}{l}\text { Average monocrystalline } \\
\text { module efficiency }\end{array}$ & CA NEM 2020 \\
\hline Module price & $\$ 0.41 / \mathrm{W}_{\mathrm{DC}}$ & $\begin{array}{l}\text { Ex-factory gate (first buyer) price, } \\
\text { Tier } 1 \text { monocrystalline modules }\end{array}$ & $\begin{array}{l}\text { Wood Mackenzie } \\
\text { and SEIA 2020; } \\
\text { NREL } 2020\end{array}$ \\
\hline \multirow[t]{2}{*}{ Inverter price } & $\begin{array}{l}\$ 0.05 / \mathrm{W}_{\mathrm{DC}} \text { (fixed- } \\
\text { tilt) }\end{array}$ & $\begin{array}{l}\text { Ex-factory gate (first buyer) price, } \\
\text { Tier } 1 \text { inverters }\end{array}$ & \multirow{2}{*}{$\begin{array}{l}\text { Wood Mackenzie and } \\
\text { SEIA 2020; Bolinger, } \\
\text { Seel, and Robson } 2019\end{array}$} \\
\hline & $\begin{array}{l}\$ 0.05 / \mathrm{W}_{\mathrm{DC}} \text { (one- } \\
\text { axis tracker) }\end{array}$ & $\begin{array}{l}\text { DC-to-AC ratio }=1.37 \text { for fixed-tilt } \\
\text { and } 1.34 \text { for one-axis tracker }\end{array}$ & \\
\hline $\begin{array}{l}\text { Structural } \\
\text { components } \\
\text { (racking) }\end{array}$ & $\begin{array}{l}\$ 0.12 / W_{D C} \text { for a } \\
100-M W \text { system }\end{array}$ & $\begin{array}{l}\text { Fixed-tilt racking or one-axis } \\
\text { tracking system }\end{array}$ & $\begin{array}{l}\text { MEPS 2019; } \\
\text { model assumptions; } \\
\text { NREL } 2020\end{array}$ \\
\hline $\begin{array}{l}\text { Electrical } \\
\text { components }\end{array}$ & $\begin{array}{l}\$ 0.07-\$ 0.13 / W_{D C} \\
\text { Varies by system } \\
\text { size }\end{array}$ & $\begin{array}{l}\text { Model was upgraded to a } 1,500-V_{D C} \\
\text { system that includes conductors, } \\
\text { conduit and fittings, transition boxes, } \\
\text { switchgear, panel boards, onsite } \\
\text { transmission, and other electrical } \\
\text { connections }\end{array}$ & $\begin{array}{l}\text { Model assumptions; } \\
\text { NREL 2020; } \\
\text { RSMeans } 2017\end{array}$ \\
\hline $\begin{array}{l}\text { EPC } \\
\text { overhead } \\
\text { (percentage } \\
\text { of equipment } \\
\text { costs) }\end{array}$ & $\begin{array}{l}8.67 \%-13 \% \text { for } \\
\text { equipment and } \\
\text { material (except } \\
\text { for transmission } \\
\text { line costs); } 23 \%- \\
69 \% \text { for labor } \\
\text { costs; varies by } \\
\text { system size and } \\
\text { labor activity }\end{array}$ & $\begin{array}{l}\text { Costs associated with EPC SG\&A, } \\
\text { warehousing, shipping, and logistics }\end{array}$ & NREL 2020 \\
\hline Sales tax & $\begin{array}{l}\text { National } \\
\text { average: } 5 \%\end{array}$ & Sales tax on equipment costs & RSMeans 2017 \\
\hline \multirow{2}{*}{$\begin{array}{l}\text { Direct } \\
\text { installation } \\
\text { labor }\end{array}$} & $\begin{array}{l}\text { Electrician: } \\
\$ 27.47 \text { per hour }\end{array}$ & \multirow[t]{2}{*}{$\begin{array}{l}\text { Modeled labor rate assumes } \\
\text { national average nonunionized labor }\end{array}$} & \multirow[t]{2}{*}{ BLS 2019; NREL 2020} \\
\hline & $\begin{array}{l}\text { Laborer: } \$ 18.17 \\
\text { per hour }\end{array}$ & & \\
\hline $\begin{array}{l}\text { Burden rates } \\
\text { (percentage } \\
\text { of direct } \\
\text { labor) }\end{array}$ & $\begin{array}{l}\text { Total nationwide } \\
\text { average: } 18 \%\end{array}$ & $\begin{array}{l}\text { Workers compensation, federal and } \\
\text { state unemployment insurance, } \\
\text { FICA, builders' risk, public liability }\end{array}$ & RSMeans 2017 \\
\hline PII & $\begin{array}{l}\$ 0.03-\$ 0.07 / \mathrm{W}_{D C} \\
\text { Varies by system } \\
\text { size }\end{array}$ & $\begin{array}{l}\text { For construction permits fee, } \\
\text { interconnection, testing, and } \\
\text { commissioning }\end{array}$ & NREL 2020 \\
\hline
\end{tabular}




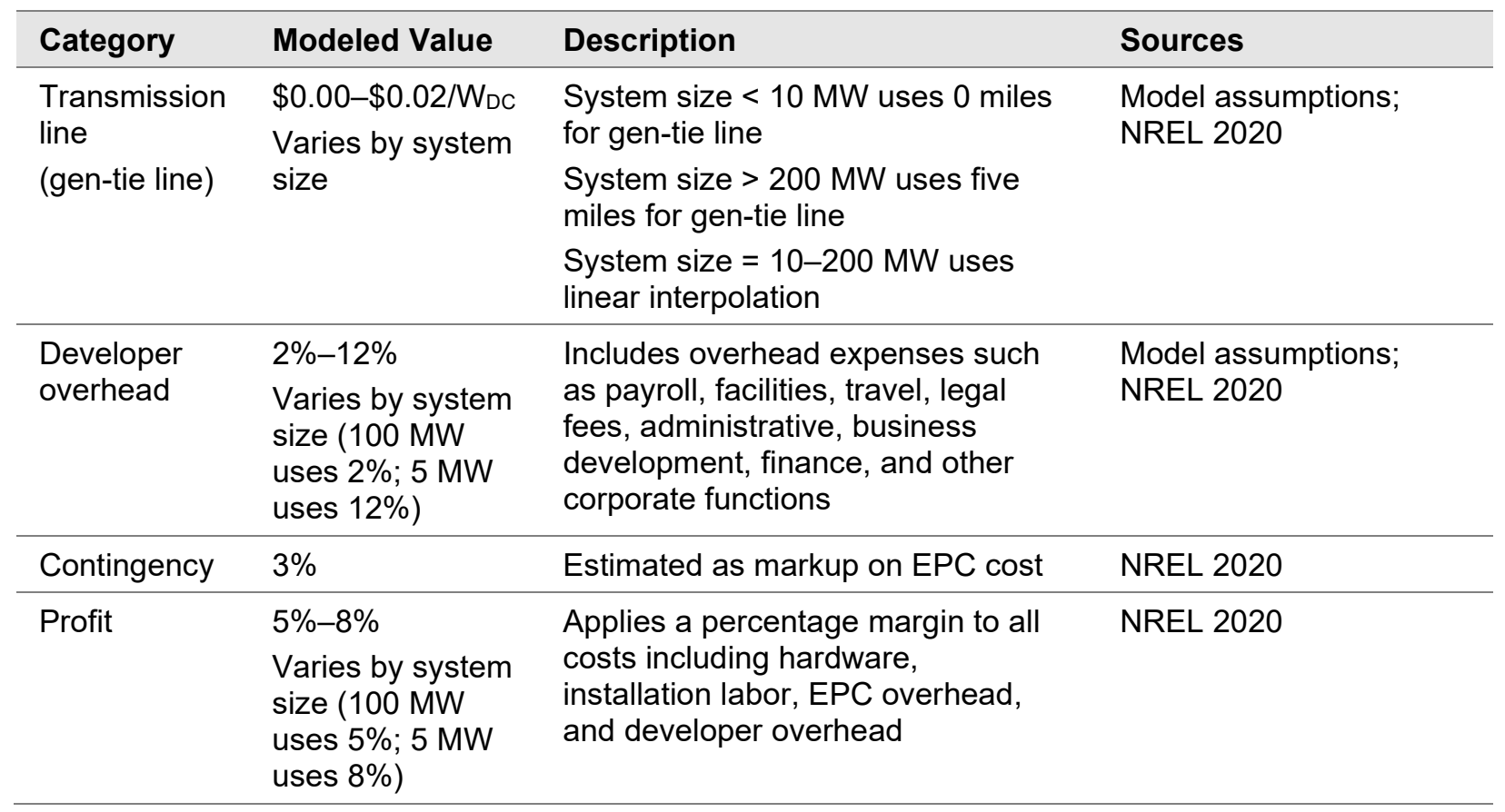

Figure 29 shows the percentage of U.S. utility-scale PV systems using tracking systems for 2010-2019. Although the data include one-axis and dual-axis tracking systems in the same "tracking" category, there are many more one-axis trackers than dual-axis trackers (EIA 2020). Cumulative tracking system installation reached $65 \%$ in 2019 , with $82 \%$ of new installations in 2019 having tracking. Based on these trends, we use fixed-tilt systems to calculate LCOE benchmarks from 2010 to 2015, and we use one-axis tracking systems for 2016 to 2020 (see Section 5.4).

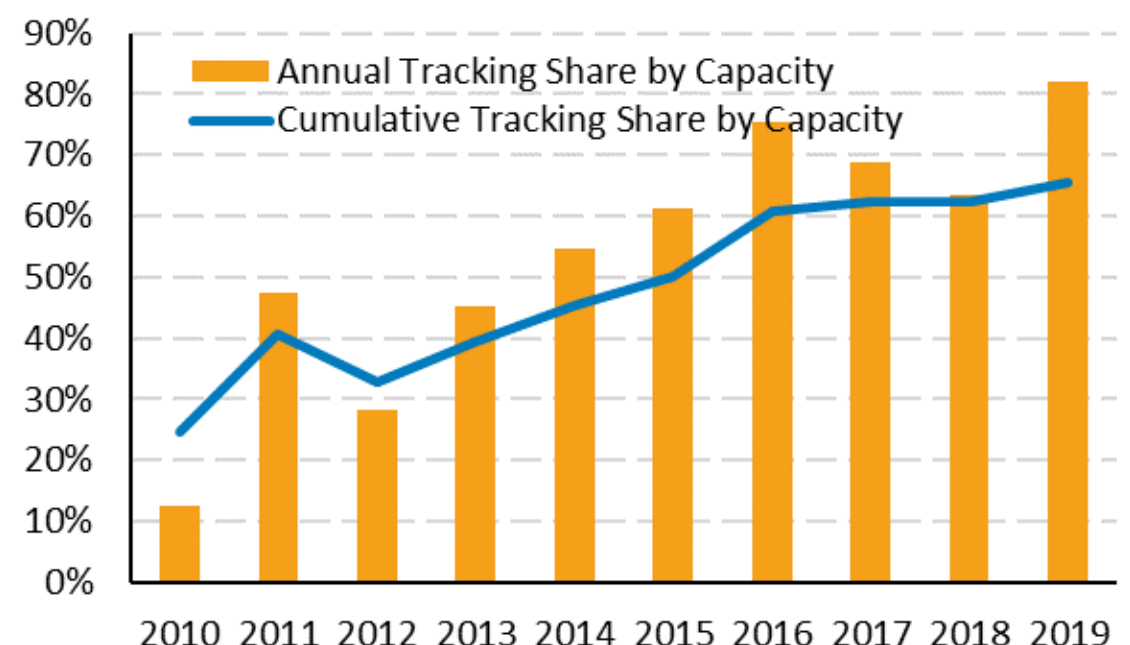

Figure 29. Percentage of U.S. utility-scale PV systems using tracking systems, 2010-2019

Source: EIA (2020) 


\subsection{Utility-Scale Model Output}

Figure 30 shows the U.S. national benchmark (EPC + developer) for fixed-tilt and one-axis tracker systems, using nonunionized labor. Figure 31 shows a sensitivity analysis for the oneaxis system benchmark, with cost categories that vary by location and hardware specification. Equipment location factor has the largest impact on installed system cost.

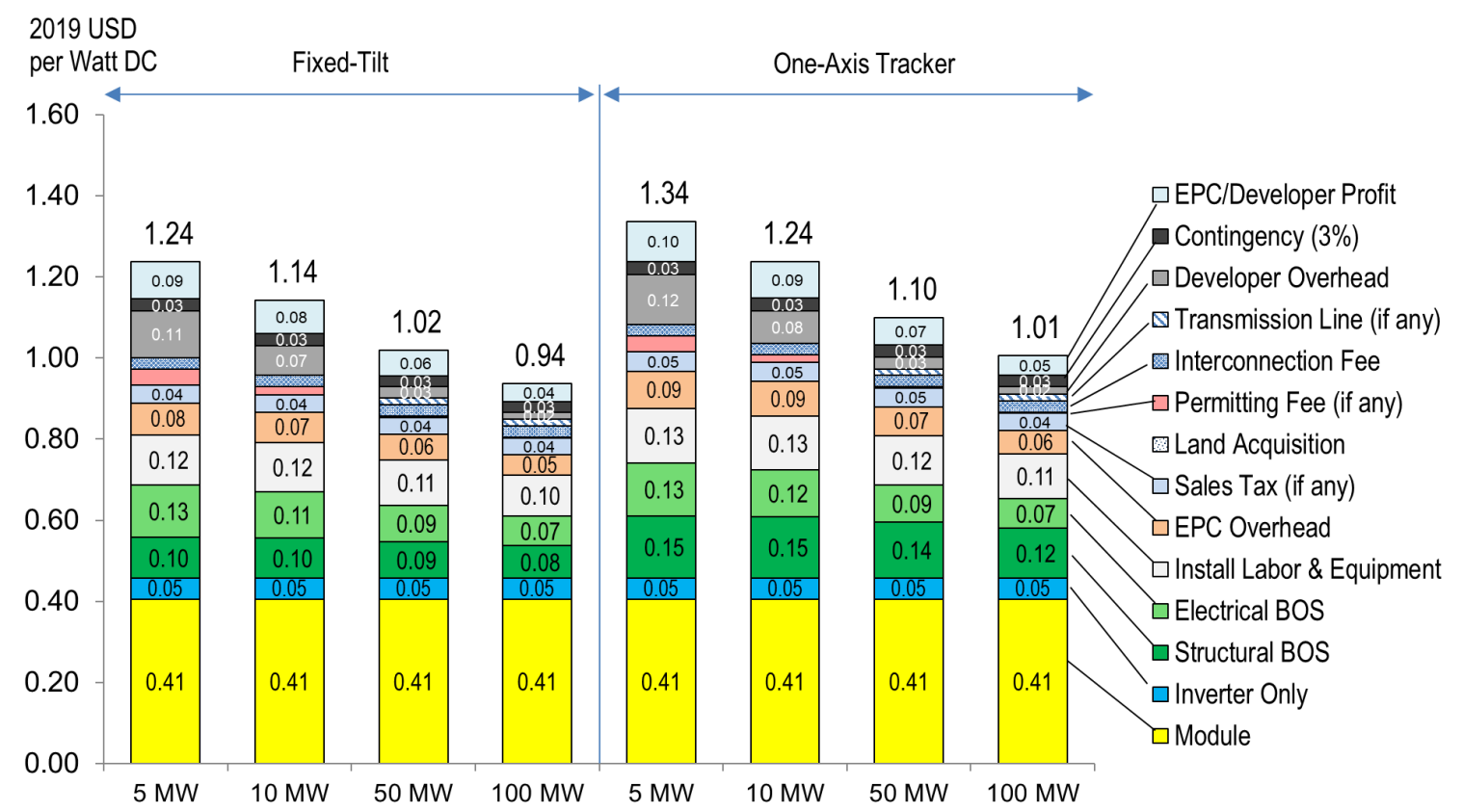

Figure 30. Q1 2020 U.S. benchmark: Utility-scale PV total cost (EPC + developer), 2019 USD/W

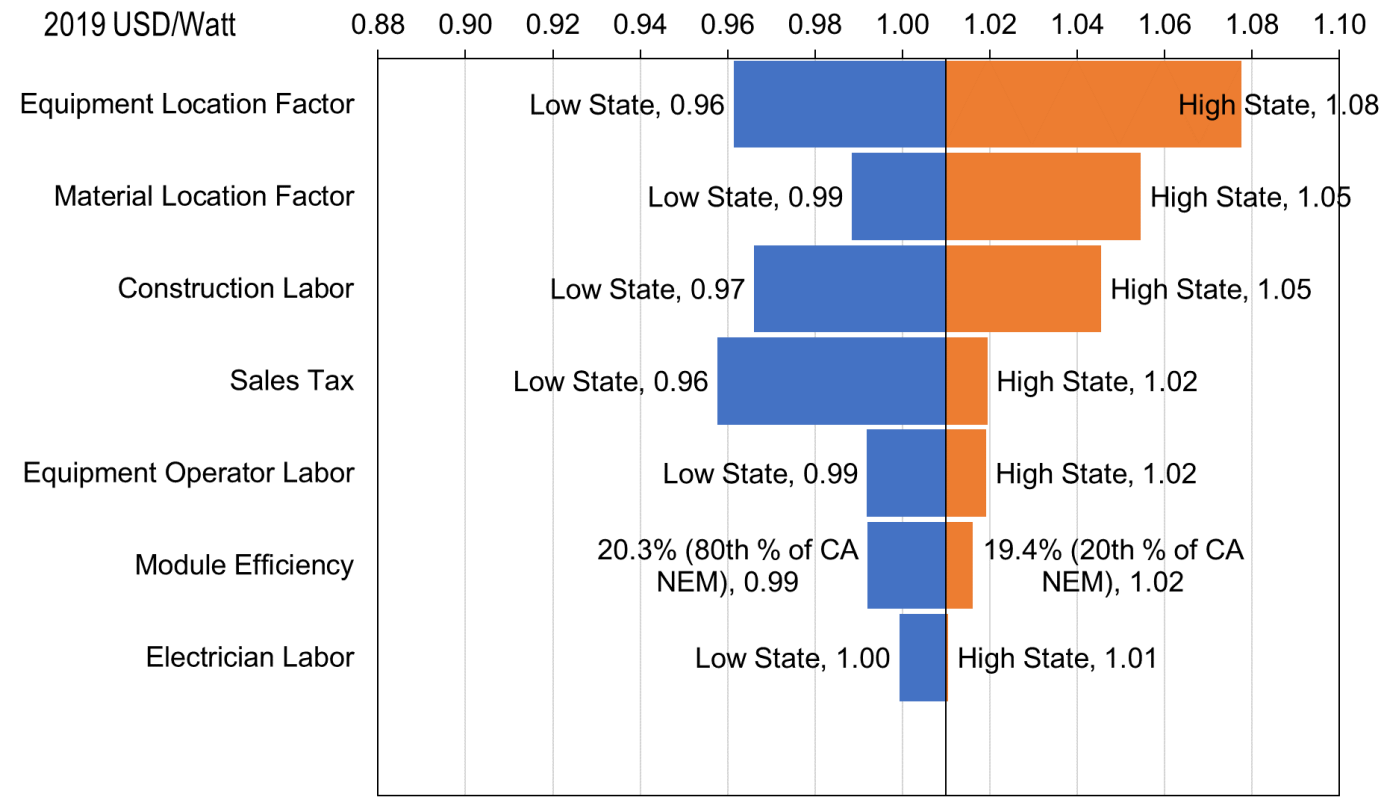

Figure 31. Sensitivity analysis for the Q1 2020 benchmark: 100-MW one-axis utility-scale PV system cost (2019 USD/W 


\subsection{Utility-Scale PV Price Benchmark Historical Trends}

Figure 32 shows the $80 \%$ (fixed-tilt) and $82 \%$ (one-axis tracking) reductions in utility-scale PV system cost benchmarks between 2010 and 2020. ${ }^{23}$ Approximately $70 \%$ (fixed-tilt) and 64\% (one-axis tracking) of those reductions can be attributed to total hardware costs, with module prices dropping $85 \%$ over that period. An additional $11 \%$ (fixed-tilt) to $12 \%$ (one-axis tracking) reduction can be attributed to labor, which dropped over that period. For previous editions of this report, we assumed a land acquisition cost of $\$ 0.03 / \mathrm{W}$. Based on Wiser et al. (2020), which stated that most utility-scale PV projects do not own the land on which the PV system is placed, we have reclassified land costs from an upfront capital expenditure (land acquisition) to an operating expenditure (lease payments) for 2019 and 2020. Therefore, approximately 1\% of the reduction in cost is attributed to the reclassification of land costs. The final $20 \%$ (fixed-tilt) and $25 \%$ (one-axis tracker) is attributable to other soft costs, including PII, sales tax, overhead, and net profit.

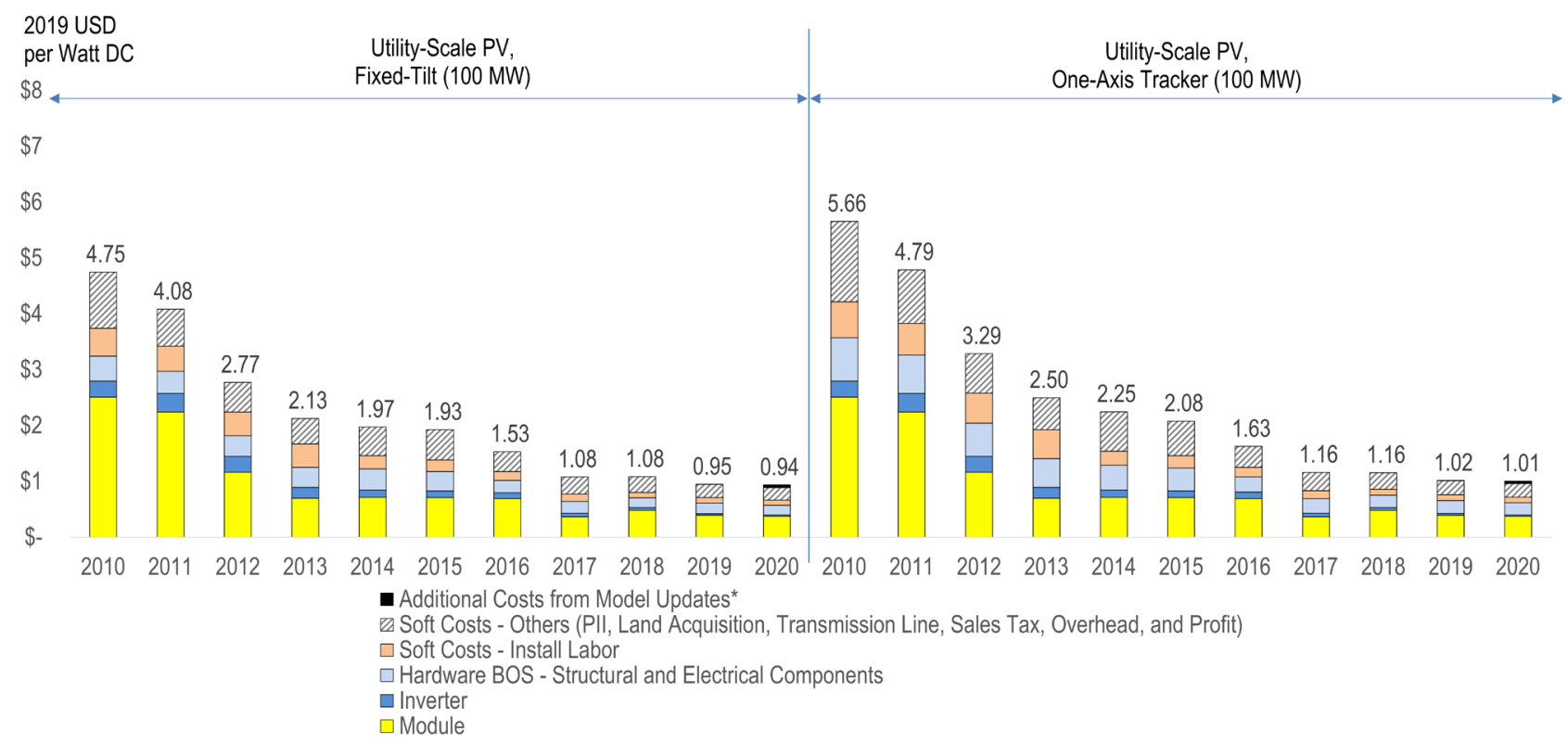

Figure 32. NREL utility-scale PV system cost benchmark summary (inflation-adjusted), 2010-2020

* The current version of our cost model makes a few significant changes from the version used in our Q1 2018 benchmark report (Fu, Feldman, and Margolis 2018) and incorporates costs that had previously not been benchmarked in as much detail. To better distinguish the historical cost trends from the changes to our cost models, we calculate Q1 2019 and Q1 2020 PV benchmarks using the Q1 2018 versions of the utility-scale PV model. The "Additional Costs from Model Updates" category represents the difference between modeled results. Using the previous costs model, the Q1 2019 and Q1 2020 benchmarks are calculated to be $\$ 0.94 / W_{D C}$ and \$0.89/WDC (fixedtilt) as well as $\$ 1.01 / \mathrm{W}_{\mathrm{DC}}$ and $\$ 0.96 / \mathrm{W}_{\mathrm{DC}}$ (one-axis), respectively.

From 2019 to 2020 , overall there was a $1 \%$ reduction in the cost benchmarks for both utilityscale PV systems (fixed-tilt and one-axis tracking).

\footnotetext{
${ }^{23}$ Each year's PV system cost benchmark corresponds to the NREL benchmark calculted in Q4 of the previous year or Q1 of the current year (e.g., 2010=Q4 2009; $2017=$ Q1 2017).
} 


\section{Comparing Multicrystalline and Monocrystalline PV Systems}

For the same reasons described in Section 3.7.1, we compare utility-scale PV system pricing using monocrystalline and multicrystalline PV modules. Figure 33 compares Q1 2019 system pricing between fixed-tilt and one-axis tracking utility-scale PV systems using the different module types, and it shows the change in price of fixed-tilt and one-axis tracking utility-scale PV systems using monocrystalline PV modules between Q1 2019 and Q1 2020.

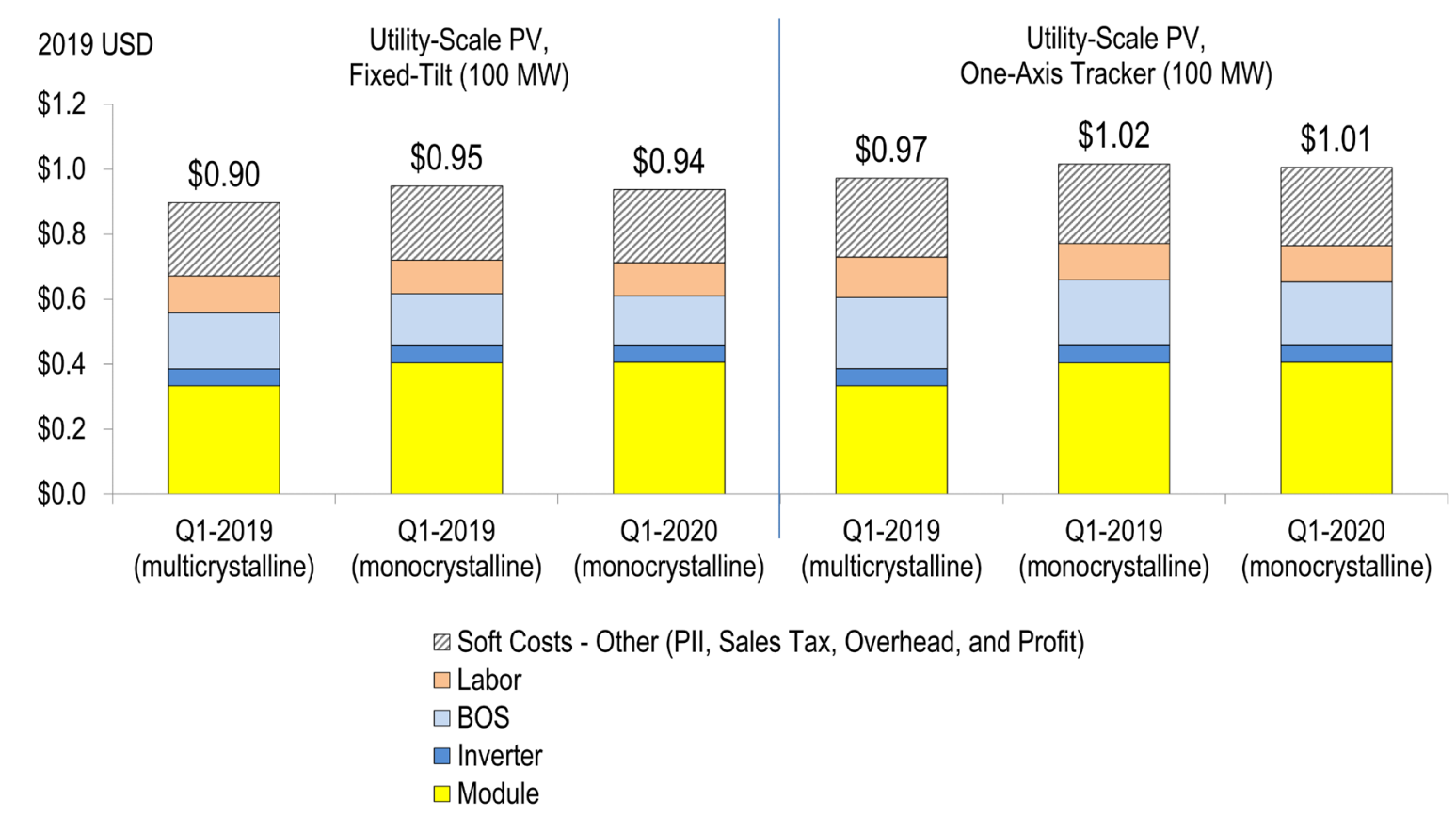

Figure 33. Q1 2019 costs for utility-scale multicrystalline PV systems and Q1 2019 and Q1 2020 costs for utility-scale monocrystalline PV systems

As shown in Figure 33, in Q1 2019 there was a \$0.05/W DC system price premium for using monocrystalline PV modules over multicrystalline PV modules in utility-scale PV systems. The system cost reductions achieved by increased monocrystalline module efficiency were counterbalanced by the higher module price. The price of utility-scale PV systems using monocrystalline modules decreased by \$0.01/W DC from Q1 2019 to Q1 2020.

\subsection{Utility-Scale PV LCOE Historical Trends}

Assumptions for the utility-scale PV LCOE benchmarks from 2010 to 2020 are summarized in Table 8 . In addition to the $82 \%$ reduction in the installed cost of utility-scale (one-axis) systems from 2010 to 2020, O\&M costs declined 40\%, annual degradation declined 30\%, equity discount rate declined $31 \%$, debt interest rate declined $27 \%$, and debt fraction increased $52 \%$. 
Using these assumptions, we calculate the utility-scale PV LCOE — with and without the 30\% federal ITC - for a high solar resource (Phoenix, CF: $21.6 \%$ for fixed-tilt and $25.2 \%$ for oneaxis), medium solar resource (Kansas City, CF: 17.3\% for fixed-tilt and 19.6\% for one-axis), and low solar resource (New York City, CF: 16.2\% for fixed-tilt and 18.1\% for one-axis) (Figure 34). We use fixed-tilt systems for LCOE benchmarks from 2010 to 2015 and then switch to oneaxis tracking systems from 2016 to 2020 to reflect the market share change in Figure 29.

From 2010 to 2020, utility-scale PV LCOE declined 83\% ( $0 \%$ between 2019 and 2020), resulting in an unsubsidized LCOE of $\$ 0.04-\$ 0.05 / \mathrm{kWh}(\$ 0.025-\$ 0.035 / \mathrm{kWh}$ when including the federal ITC). This reduction signifies the achievement of SETO's 2020 utility-scale PV goal. ${ }^{24}$ We also calculate PV LCOE without the ITC using steady-state financing assumptions. Under these assumptions, utility-scale (one-axis and fixed-tilt) PV LCOE ranges from $\$ 0.04$ $\$ 0.05 / \mathrm{kWh}$ in Q1 2020.

\footnotetext{
${ }^{24}$ The 2020 utility-scale goal is not adjusted for inflation, because wholesale electricity prices were relatively flat, and in some cases declined, from 2010 to 2020. The goal is shown in Appendix B along with the detailed utilityscale LCOE values over time.
} 
Table 8. One-Axis Tracker and Fixed-Tilt Utility-Scale PV: LCOE Assumptions, 2010-2020 (2019 USD/W

\begin{tabular}{|c|c|c|c|c|c|c|c|c|c|c|c|}
\hline & 2010 & 2011 & 2012 & 2013 & 2014 & 2015 & 2016 & 2017 & 2018 & 2019 & 2020 \\
\hline \multicolumn{12}{|l|}{ One-Axis Tracker } \\
\hline Installed cost $(\$ / \mathrm{W})$ & 5.66 & 4.79 & 3.29 & 2.50 & 2.25 & 2.08 & 1.63 & 1.16 & 1.16 & 1.02 & 1.01 \\
\hline Annual degradation (\%) & 1.00 & 0.95 & 0.90 & 0.85 & 0.80 & 0.75 & 0.75 & 0.75 & 0.70 & 0.70 & 0.70 \\
\hline O\&M expenses (\$/kW-yr) & 29 & 28 & 26 & 25 & 24 & 22 & 22 & 21 & 15 & 17 & 17 \\
\hline Preinverter derate (\%) & 90.5 & 90.5 & 90.5 & 90.5 & 90.5 & 90.5 & 90.5 & 90.5 & 90.5 & 90.5 & 90.5 \\
\hline Inverter efficiency (\%) & 96.0 & 96.4 & 96.8 & 97.2 & 97.6 & 98.0 & 98.0 & 98.0 & 98.0 & 98.0 & 98.0 \\
\hline Inverter loading ratio & 1.10 & 1.12 & 1.13 & 1.15 & 1.17 & 1.18 & 1.20 & 1.30 & 1.30 & 1.34 & 1.34 \\
\hline \multicolumn{12}{|l|}{ Fixed-Tilt } \\
\hline Installed cost $(\$ / \mathrm{W})$ & 4.75 & 4.08 & 2.77 & 2.13 & 1.97 & 1.93 & 1.53 & 1.08 & 1.08 & 0.95 & 0.94 \\
\hline Annual degradation (\%) & 1.00 & 0.95 & 0.90 & 0.85 & 0.80 & 0.75 & 0.75 & 0.75 & 0.70 & 0.70 & 0.70 \\
\hline O\&M expenses $(\$ / k W-y r)$ & 29 & 27 & 25 & 23 & 21 & 19 & 19 & 18 & 13 & 16 & 16 \\
\hline Preinverter derate (\%) & 90.5 & 90.5 & 90.5 & 90.5 & 90.5 & 90.5 & 90.5 & 90.5 & 90.5 & 90.5 & 90.5 \\
\hline Inverter efficiency (\%) & 96.0 & 96.4 & 96.8 & 97.2 & 97.6 & 98.0 & 98.0 & 98.0 & 98.0 & 98.0 & 98.0 \\
\hline Inverter loading ratio & 1.10 & 1.15 & 1.20 & 1.25 & 1.30 & 1.35 & 1.40 & 1.30 & 1.36 & 1.37 & 1.37 \\
\hline \multicolumn{12}{|l|}{ Financing Assumptions } \\
\hline Inflation rate (\%) & 2.5 & 2.5 & 2.5 & 2.5 & 2.5 & 2.5 & 2.5 & 2.5 & 2.5 & 2.5 & 2.5 \\
\hline \multicolumn{12}{|l|}{ Market Case } \\
\hline Equity discount rate (real) (\%) & 7.4 & 7.2 & 7.0 & 6.9 & 6.7 & 6.5 & 6.3 & 6.3 & 6.3 & 5.1 & 5.1 \\
\hline Debt interest rate (\%) & 5.5 & 5.3 & 5.2 & 5.0 & 4.8 & 4.7 & 4.5 & 4.5 & 4.5 & 4.0 & 4.0 \\
\hline Debt fraction (\%) & 34.2 & 35.2 & 36.1 & 37.1 & 38.1 & 39.0 & 40.0 & 40.0 & 40.0 & 51.9 & 51.9 \\
\hline \multicolumn{12}{|l|}{ Steady-State Financing } \\
\hline Equity discount rate (real) (\%) & - & - & - & 一 & - & - & - & - & 一 & - & 5.1 \\
\hline Debt interest rate (\%) & - & - & - & - & - & - & - & - & - & - & 5.0 \\
\hline Debt fraction (\%) & - & - & - & - & - & - & - & - & - & - & 71.8 \\
\hline
\end{tabular}

All 2010-2018 data are from Fu, Feldman, and Margolis (2018), and they are adjusted for inflation. Utility-scale PV system LCOEs assume:

(1) System lifetime of 30 years 

(2) Federal tax rate of $21 \%$
(3) State tax rate of $6 \%$
(4) MACRS depreciation schedule
(5) No state or local subsidies
(6) A working capital and debt service reserve account for six months of operating costs and debt payments (earning interest of $1.75 \%$ )
(7) Six-month construction loan with an interest rate of $4 \%$ and a fee of $1 \%$ of the cost of the system
(8) System size of $100 \mathrm{MW}$
(9) Debt with a term of 18 years
(10) \$1.1 million of upfront financial transaction costs
(11) 2019 and 2020 financial assumptions from Feldman, Bolinger, and Schwabe (2020) 


\section{SETO Goal (in 2019 USD): \\ LCOE $=6.4$ cents $/ \mathrm{kWh}$ without ITC. 2030 SETO Goal \\ (in 2019 USD): $L C O E=3.2$ cents/ $\mathrm{kWh}$ without ITC}

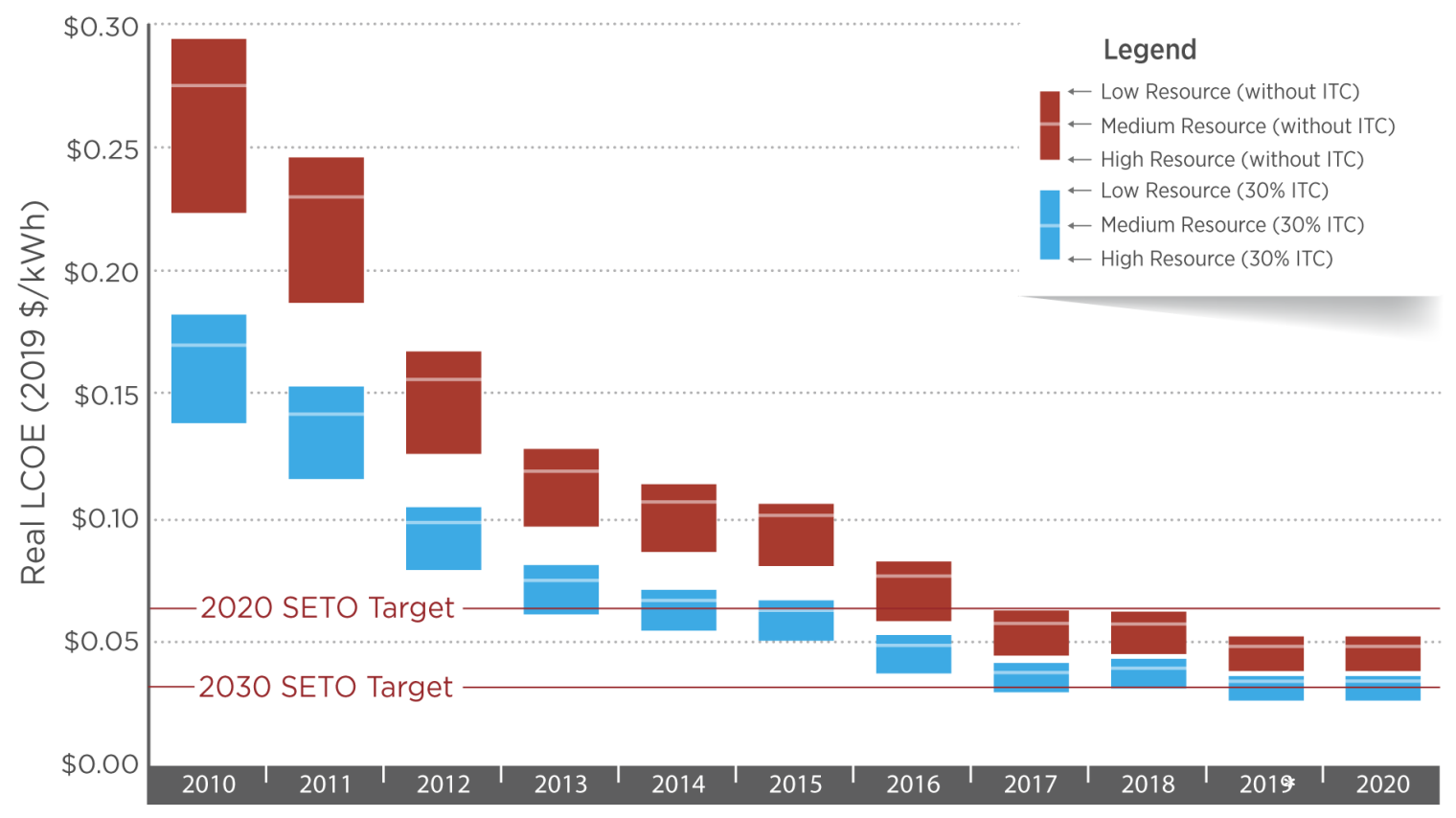

Figure 34. LCOE for utility-scale PV systems, by region, with and without ITC, 2010-2020 (fixed-tilt from 2010 to 2015, one-axis tracking from 2016 to 2020)

We updated our methods and model this year; 2019 and 2020 LCOEs are higher than they would have been using previous models. Appendix A provides a detailed discussion of the changes made to the models between the previous version (Fu, Feldman, and Margolis 2018) and this year's version. LCOE is calculated for each scenario under a range of $\mathrm{CFs}$, but all other values remain the same. 


\section{Residential Storage and PV-plus-Storage Model}

To analyze component costs and system prices for PV-plus-storage installed in Q1 2020, we adapt NREL's component- and system-level modeling approach for standalone PV. For this report, system configuration refers to four characteristics that determine a PV-plus-storage system's functionality:

- PV system capacity $(\mathrm{kW})$

- Battery energy capacity $(\mathrm{kWh})$

- Battery power capacity $(\mathrm{kW})$

- Whether the battery is DC- or AC-coupled. ${ }^{25}$

Customer preference for specific characteristics is based on several factors, including cost, load profile, and planned use of the system for load shifting (storing energy in one period for use in a later period). In general, customers who have loads with high peaks of short duration may desire a high-power (high-kW) battery capable of meeting the high peak. Customers who have flatter loads with lower peaks of longer duration may prefer a high-energy (high-kWh) battery capable of longer-duration energy discharge.

A PV array, a battery, and a battery-based inverter are the fundamental components of every PVplus-storage system. Additional component requirements are determined by whether the system is DC- or AC-coupled ${ }^{26}$ : a DC-coupled system often requires a charge controller to step down the PV output voltage to a level that is safe for the battery, whereas an AC-coupled system requires a grid-tied inverter to feed PV output directly to the customer's load or the grid. ${ }^{27}$ For a detailed discussion of the differences and considerations related to DC-versus AC-coupled system configurations, see Ardani et al. (2017).

Based on our industry interviews, increasing numbers of end users are willing to pay a premium for larger, more-resilient PV-plus-storage systems with enhanced back-up power capabilities, owing to the increased occurrence of superstorms and natural disasters. This decision may not always be driven by economics, given the higher costs of PV-plus-storage systems today; however, consumer-adoption motivations extend beyond economics to concerns about security, safety, and resiliency (EuPD Research and Greentech Media 2016).

When considering PV-plus-storage for enhanced back-up power, optimal system configurations and technology choices are determined by the system application. We model a larger, moreresilient PV-plus-storage system (7-kW PV plus 5-kW/20-kWh storage) designed for daily PV self-consumption and enhanced back-up capabilities. The average U.S. home uses about $30 \mathrm{kWh}$ of electricity each day, with large variations based on location and season. Assuming an average household could cut its electricity use by two thirds in an emergency, it would need to meet

\footnotetext{
${ }^{25}$ NREL's modeled DC-coupled system includes a single dual-function inverter that is tied to both the PV array and the battery. In our AC-coupled system, to charge a battery, PV power is first converted (DC to AC) through a gridtied inverter and then converted (AC to DC) through a battery-based inverter.

${ }^{26}$ Our discussion is simplified to explain the basic technical differences between AC- and DC-coupled systems. However, the decision to use AC- or DC-coupling might also be driven by non-technical factors such as policy, contractual obligations, and economics.

${ }^{27}$ Some Li-ion battery packs have built-in safety controls, such as those integrated in a battery management system, but some do not. For consistency, our model assumes there is a dedicated charge controller.
} 
$10 \mathrm{kWh}$ of demand each day. At this rate, our more-resilient system could provide back-up electricity for an average of 35 hours without PV recharging. In contrast, our less-resilient battery system (3-kW/6-kWh storage) could only provide back-up electricity for an average of 10 hours without PV recharging. ${ }^{28}$ If $30 \%$ of the PV system's average output were available to charge the battery each day, the more-resilient battery system could provide back-up electricity for about four days, compared with about one day for the less-resilient battery system. ${ }^{29}$ The higher power of the more-resilient battery system $(5 \mathrm{~kW})$ - compared with the less-resilient battery system $(3 \mathrm{~kW})$ - would also enable the more-resilient battery system to meet higher peak electricity demands during a grid outage (e.g., to run a refrigerator).

Sections 6.1 and 6.2 present the residential storage and PV-plus-storage cost models, Section 6.3 shows the model outputs, Section 6.4 compares PV-plus-storage benchmark trends over time, and Section 6.5 benchmarks the levelized cost for a residential PV-plus-storage system.

\subsection{Residential Li-lon Standalone Storage Cost Model}

The residential storage market is predominantly composed of fully integrated storage kits, which include Li-ion battery packs, inverters, field wiring, disconnect, and casing. Although this equipment is sold as one product, we model these components separately to compare costs across storage kit sizes and configurations. Table 9 presents the detailed modeling inputs and assumptions for the residential standalone storage costs.

Table 9. Residential Storage-Only Modeling Inputs and Assumptions

\begin{tabular}{|c|c|c|}
\hline Category & Modeled Value & Description \\
\hline \multirow[t]{2}{*}{ System size } & 3-kW/6-kWh storage & Less-resilient system \\
\hline & 5-kW/20-kWh storage & More-resilient system \\
\hline $\begin{array}{l}\text { Battery pack } \\
\text { cost }\end{array}$ & $\$ 253 / \mathrm{kWh}$ & Battery pack only \\
\hline \multirow[t]{2}{*}{$\begin{array}{l}\text { Battery-based } \\
\text { inverter cost }\end{array}$} & $\$ 174 / \mathrm{kWh}$ & $\begin{array}{l}6-\mathrm{kW}, 48-\mathrm{V} \text { bidirectional inverter (less } \\
\text { resilient) }\end{array}$ \\
\hline & & $\begin{array}{l}\text { 8-kW, 48-V bidirectional inverter (more } \\
\text { resilient) }\end{array}$ \\
\hline \multirow{3}{*}{$\begin{array}{l}\text { Electrical } \\
\text { BOS cost }\end{array}$} & • $\$ 1,830$ (DC-coupled) & \multirow{3}{*}{$\begin{array}{l}\text { Revenue-grade meter, communications } \\
\text { device, AC main panel, DC disconnect, } \\
\text { maximum power point tracking, charge } \\
\text { controller, subpanel (breaker box) for } \\
\text { critical load, conduit, wiring, DC cable }\end{array}$} \\
\hline & • $\$ 1,520$ (AC-coupled) & \\
\hline & $\begin{array}{l}\text { Assumes higher electrical BOS costs } \\
\text { for DC-coupled systems that are due } \\
\text { to the need for a charge controller }\end{array}$ & \\
\hline
\end{tabular}

\footnotetext{
${ }^{28}$ These calculations assume $80 \%$ depth of discharge for the batteries and $90 \%$ inverter efficiency. Even in these simplified scenarios, the actual amount of time that the system could provide back-up electricity would depend on the battery's charge level and the time of day at the time of the outage as well as the home's load profile. ${ }^{29}$ This is based on 2016 results using NREL's PVWatts for a 5.6-kW PV system located in Denver (5.6 kW was the calculated system size for a 22-module PV system in 2016, based on average module efficiency). This modeled system generates $8,179 \mathrm{kWh}$ per year (average, $22.4 \mathrm{kWh}$ per day). Thus, we assume this same $5.6-\mathrm{kW}$ PV array will generate an average of $6.7 \mathrm{kWh}$ per day when only $30 \%$ of the total PV resource is available owing to severe weather conditions. Since 2016, our residential PV benchmark has increased in capacity, but battery storage capacity has remained flat. The storage capacities benchmarked here conform with what we observed in the marketplace.
} 


\begin{tabular}{|c|c|c|}
\hline Category & Modeled Value & Description \\
\hline $\begin{array}{l}\text { Supply-chain } \\
\text { costs }\end{array}$ & $5 \%$ of cost of equipment & $\begin{array}{l}\text { Includes costs of inventory, shipping, } \\
\text { and handling of equipment }\end{array}$ \\
\hline Sales tax & $5.1 \%$ (national average) & Sales tax on the equipment \\
\hline $\begin{array}{l}\text { Installation labor } \\
\text { cost }\end{array}$ & $\begin{array}{l}\text { Electrician: } \$ 27.47 \text { per hour } \\
\text { Laborer: } \$ 18.17 \text { per hour } \\
\text { AC systems require more hours of } \\
\text { work to integrate with an existing } \\
\text { inverter and monitoring system }\end{array}$ & Assumes national average pricing \\
\hline Engineering fee & $\$ 99$ & $\begin{array}{l}\text { Engineering design and professional } \\
\text { engineer-stamped calculations and } \\
\text { drawings }\end{array}$ \\
\hline PII & $\begin{array}{l}\$ 297 \text { permit fee } \\
\$ 594-\$ 951 \text { in labor }\end{array}$ & $\begin{array}{l}20-32 \text { hours (DC-coupled/AC-coupled) } \\
\text { of commissioning and interconnection } \\
\text { labor, and permit fee }\end{array}$ \\
\hline $\begin{array}{l}\text { Sales and } \\
\text { marketing } \\
\text { (customer } \\
\text { acquisition) }\end{array}$ & $\$ 0.61 / \mathrm{W}_{D C}$ & $\begin{array}{l}20 \text { hours more time for DC system, and } \\
32 \text { hours more for AC system, per } \\
\text { closed sale, associated with selling a } \\
\text { storage systems versus selling a PV } \\
\text { system }\end{array}$ \\
\hline $\begin{array}{l}\text { Overhead } \\
\text { (general and } \\
\text { administrative) }\end{array}$ & $\$ 0.28 / \mathrm{W}_{D C}$ & $\begin{array}{l}\text { Rent, building, equipment, staff } \\
\text { expenses not directly tied to PII, } \\
\text { customer acquisition, or direct } \\
\text { installation labor }\end{array}$ \\
\hline Profit (\%) & $17 \%$ & $\begin{array}{l}\text { Fixed percentage margin applied to all } \\
\text { direct costs including hardware, } \\
\text { installation labor, direct sales and } \\
\text { marketing, design, installation, and } \\
\text { permitting fees }\end{array}$ \\
\hline
\end{tabular}

As demonstrated in Figure 35, the kit for a 3-kW/6-kWh storage system costs approximately $\$ 4,200-\$ 4,600$, with a total installed cost of $\$ 11,823$ (DC-coupled) to $\$ 12,287$ (AC-coupled). The kit for a $5-\mathrm{kW} / 20-\mathrm{kWh}$ storage system costs approximately $\$ 10,400-\$ 10,800$, with a total installed cost of $\$ 21,471$ (DC-coupled) to $\$ 22,041$ (AC-coupled). ${ }^{30}$

\footnotetext{
${ }^{30} \mathrm{We}$ assume all batteries are installed inside the home. Installation of batteries outside would require additional BOS hardware, such as a concrete pad and associated container. Such additional BOS hardware would add to the benchmarked price of our modeled systems.
} 


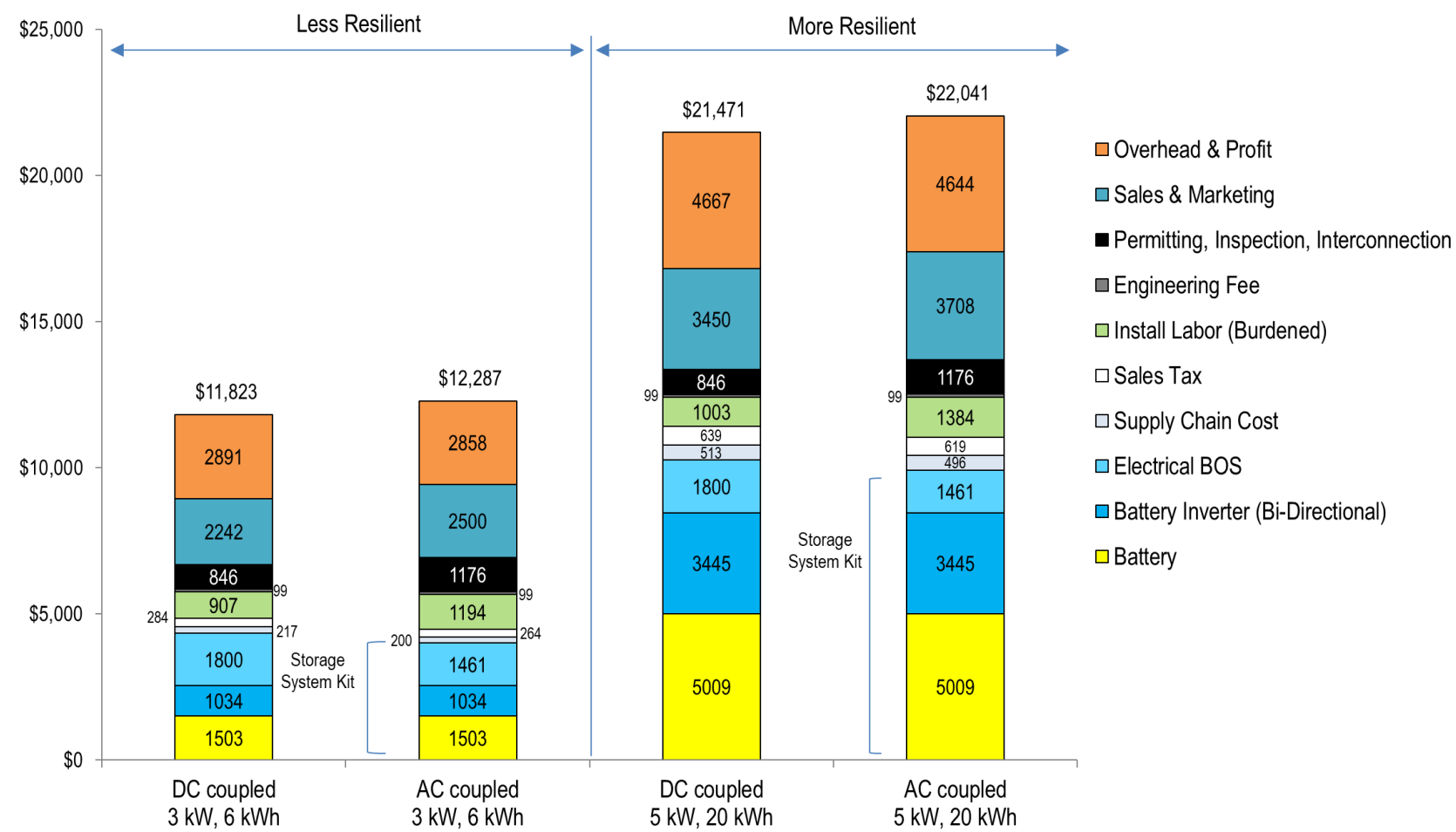

Figure 35. Installed cost of residential storage only

\subsection{Residential PV-plus-Storage System Cost Model}

We model a 7-kW PV system coupled with a $3-\mathrm{kW} / 6-\mathrm{kWh}$ or $5-\mathrm{kW} / 20-\mathrm{kWh}$ storage system, using the same PV assumptions we used with our standalone PV system. Figure 36 provides a schematic of typical DC- and AC-coupled PV systems with battery back-up. Table 3, Table 9, and Table 10 present modeling inputs and assumptions. 


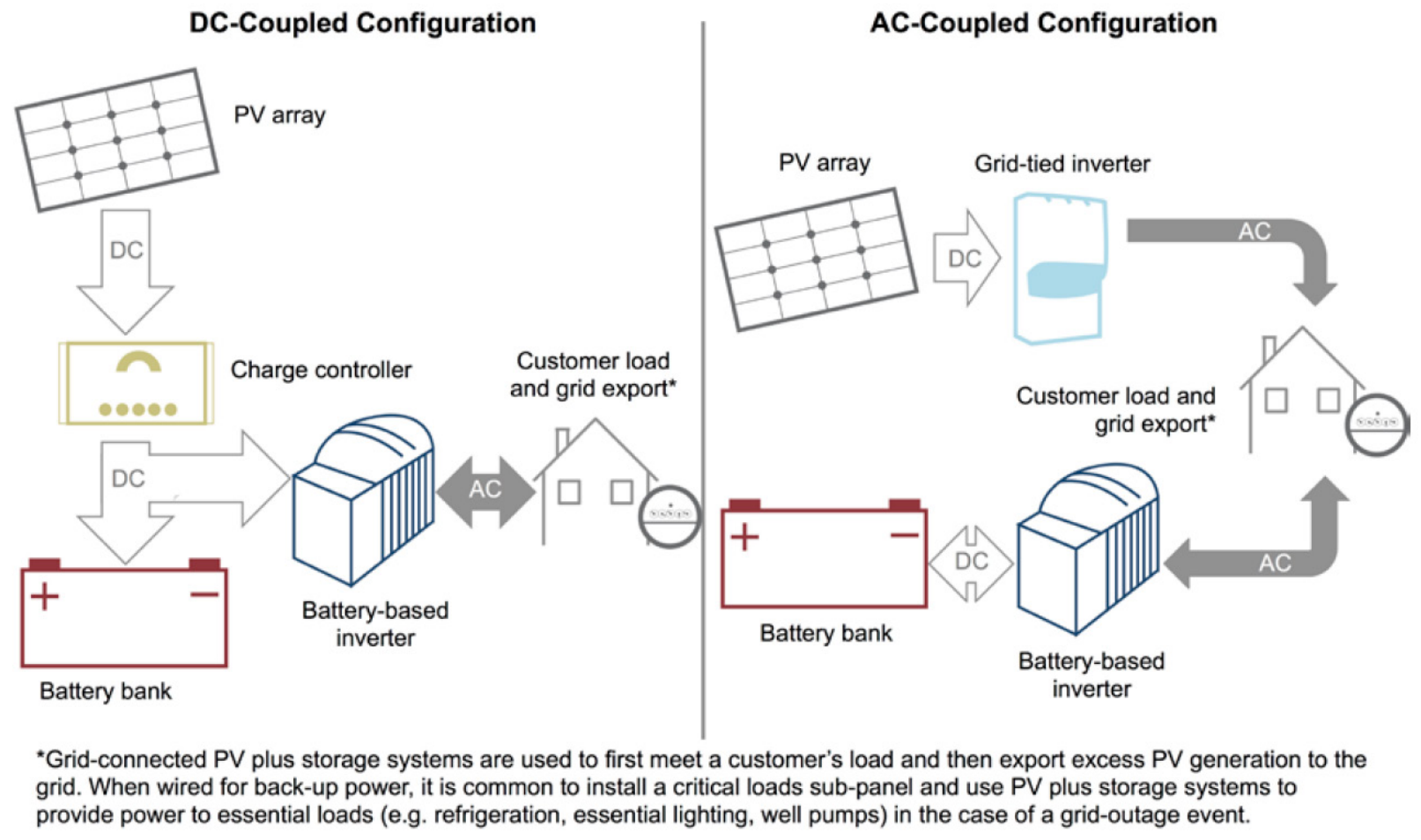

Figure 36. Modeled DC- and AC-coupled system configurations

Figure is simplified for illustrative purposes.

Table 10. Changes to Residential PV and Storage Models When PV and Storage Are Combined

\begin{tabular}{|c|c|c|}
\hline Category & Modeled Value & Description \\
\hline Electrical BOS & $\begin{array}{l}90 \% \text { of the combined BOS costs for PV } \\
\text { and battery standalone systems }\end{array}$ & Duplicative parts are removed. \\
\hline $\begin{array}{l}\text { Installation } \\
\text { labor }\end{array}$ & $\begin{array}{l}90 \% \text { of the combined BOS costs for PV } \\
\text { and battery standalone systems }\end{array}$ & Duplicative work is removed. \\
\hline $\begin{array}{l}\text { Sales and } \\
\text { marketing }\end{array}$ & $\begin{array}{l}20 \text { hours more time for DC system, and } \\
32 \text { hours more for AC system, per } \\
\text { closed sale, associated with selling a } \\
\text { PV system with storage }\end{array}$ & $\begin{array}{l}\text { Additional explanation, calculations, and } \\
\text { a lower close rate, and the AC system } \\
\text { requires more customer site assessment. }\end{array}$ \\
\hline
\end{tabular}

\subsection{Residential Model Output}

Figure 37 compares cost and price components for a standalone PV system as well as PV-plusstorage systems with less-resilient (3-kW/6-kWh) and more-resilient $(5-\mathrm{kW} / 20-\mathrm{kWh})$ battery systems. With DC-coupling, the price of the more-resilient system is $\$ 35,591$, which is $\$ 9,438$ $(36 \%)$ more than the price of the DC-coupled less-resilient system. With AC-coupling, the price of the more-resilient battery system is $\$ 37,909$, which is $\$ 9,538(34 \%)$ more than the price of the DC-coupled less-resilient battery system. The premium is due to the more-resilient systems' higher battery, inverter, BOS, and labor costs plus indirect costs (profit, sales tax, and supplychain costs). 


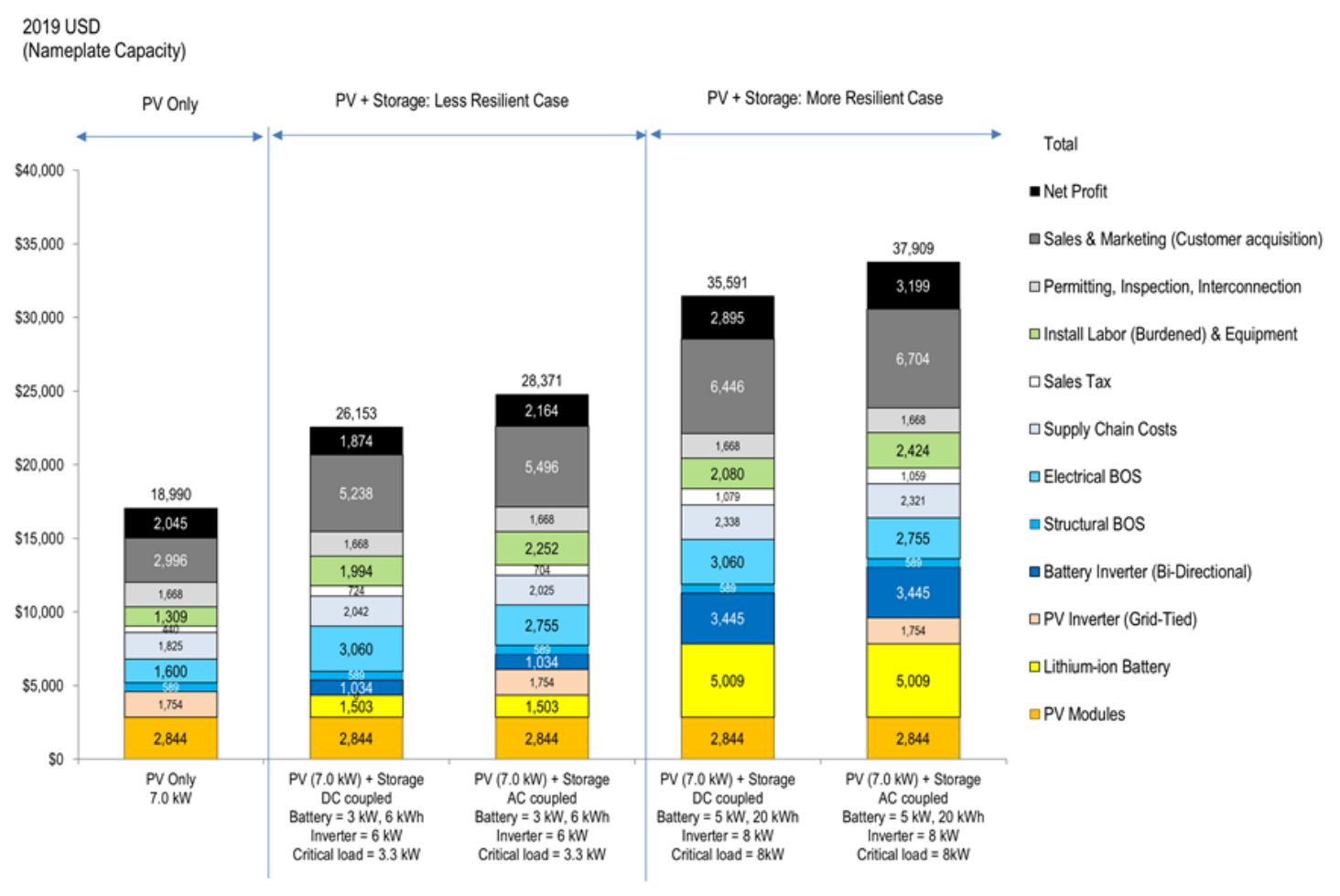

Figure 37. Modeled total installed cost and price components for residential PV-plus-storage systems, less-resilient versus more-resilient battery case (2019 USD)

\subsection{Residential PV-plus-Storage Price Benchmark Historical Trends}

Figure 38 shows the $11 \%$ and $25 \%$ reductions in residential PV-plus-storage benchmarks between 2016 (Ardani et al. 2017) and 2020, for the AC-coupled less-resilient and more-resilient cases, respectively. ${ }^{31}$ The reduction is due to a $26 \%$ reduction in PV module costs, $38 \%$ and $44 \%$ reduction in costs associated with the storage system kit (including a bidirectional inverter), a $16 \%$ reduction in hardware BOS, and a $34 \%$ and $65 \%$ reduction in labor costs. These cost reductions are partially offset by $18 \%$ and $10 \%$ increases in other soft costs (including PII, sales tax, overhead, and net profit). Other soft costs increased between 2016 and 2020 because of a change in methodology and because the rated capacity of the 22-module system increased from $5.6 \mathrm{~kW}$ to $7.0 \mathrm{~kW}$ between 2016 and 2020. From 2019 to 2020, the residential PV-plus-storage system cost benchmarks decreased by $5 \%$, mostly owing to lower storage system kit prices.

\footnotetext{
${ }^{31}$ Each year's PV system cost benchmark corresponds to the NREL benchmark calculated in Q1 of the current year (e.g., $2016=\mathrm{Q} 1$ 2016). Figure 38 only shows AC-coupled system costs to more easily demonstrate the historical trends; the cost of DC-coupled systems follows the same historical trends.
} 


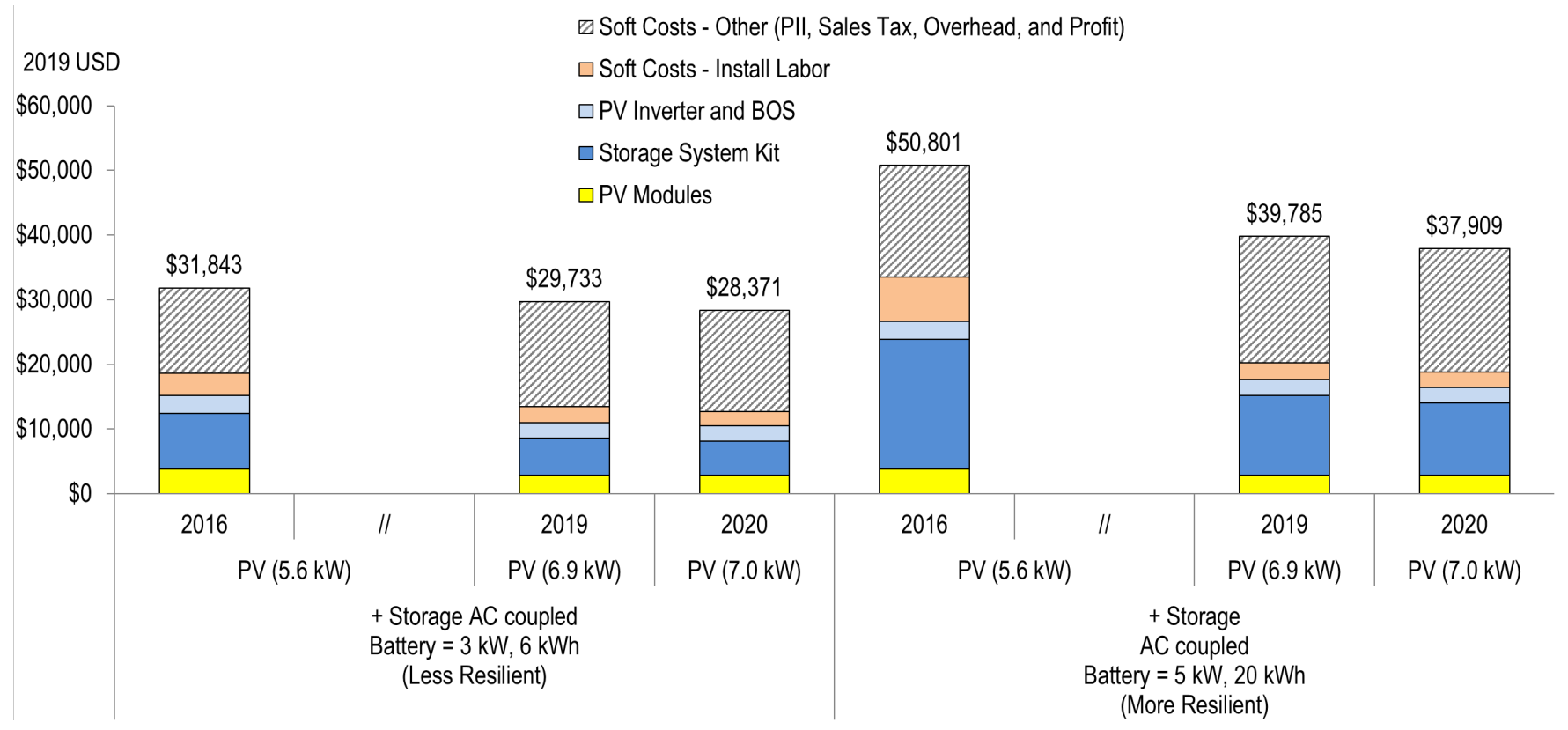

Figure 38. Residential PV-plus-storage system cost benchmark summary, 2016, 2019, and 2020

The 2016 benchmarks differ from those originally published, because values are adjusted for inflation.

\subsection{Residential Levelized Cost of Solar-plus-Storage}

For this year's benchmark report, we derive a formula for the levelized cost of solar-plus-storage (LCOSS) to contextualize our upfront PV-plus-storage system benchmarks and better represent the total cost of operating a PV-plus-storage system, on a per-kWh basis. BNEF (2019c) and Lazard (2018) performed similar LCOSS calculations. None of these LCOSS calculations, including the one in this report, attempts to value the electricity generated by these systems or the different ways they may operate. Storage value calculations for residential applications require integrating storage dispatch into building load, retail rates, and requirements. In addition, residential storage systems perform various functions - such as shifting load, reducing peak demand, and providing emergency power-depending on location, regulations, and customer preferences; our analysis represents the load-shifting use case. For a detailed discussion of residential storage value, see Fitzgerald et al. (2015), DiOrio et al. (2015), and Darghouth et al. (2019). Similar to LCOE, LCOSS does not focus on value but rather can help track improvements to all costs associated with residential PV-plus-storage systems over time (as opposed to just upfront costs), and the metric can provide limited comparisons with other dispatchable electricity generation technologies (e.g., PV-plus-generator systems). Table 11 lists our model inputs and assumptions for calculating residential LCOSS. 
Table 11. Residential LCOSS Inputs and Assumptions

\begin{tabular}{|c|c|c|}
\hline Model Component & Model Input & Description \\
\hline System size & $\begin{array}{l}\text { 7-kW PV plus 3-kW/6-kWh } \\
\text { storage system }\end{array}$ & \\
\hline Initial investment & $\$ 28,371$ & $\begin{array}{l}2020 \text { residential PV-plus-storage } \\
\text { benchmark, AC-coupled }\end{array}$ \\
\hline $\begin{array}{l}\text { First follow-on } \\
\text { investments (inverter, } \\
\text { battery replacements) }\end{array}$ & $\$ 240$ in year 10 & $\begin{array}{l}20 \% \text { of the batteries are replaced after } \\
10 \text { years due to battery capacity dropping } \\
20 \% \text {. We assume costs for battery and } \\
\text { bidirectional inverters drop } 20 \% \text { in the } \\
\text { next } 10 \text { years. }\end{array}$ \\
\hline $\begin{array}{l}\text { Second follow-on } \\
\text { investments (inverter, } \\
\text { battery replacements) }\end{array}$ & $\$ 180$ in year 20 & $\begin{array}{l}20 \% \text { of the batteries are replaced after } \\
20 \text { years due to battery capacity dropping } \\
20 \% \text {. We assume costs for battery and } \\
\text { bidirectional inverters drop } 40 \% \text { in the } \\
\text { next } 20 \text { years. }\end{array}$ \\
\hline Real discount rate & $3.1 \%$ & Consistent with LCOE formula \\
\hline Tax rate & $25.7 \%$ & $21 \%$ federal, $6 \%$ state \\
\hline Residual value & $\$ 0$ & \\
\hline $\begin{array}{l}\text { Initial annual PV } \\
\text { system production }\end{array}$ & $\begin{array}{l}\text { High resource: } 1,892 \mathrm{MWh} / \mathrm{MW} \\
\text { Medium resource: } 1,546 \\
\text { MWh/MW } \\
\text { Low resource: } 1,440 \mathrm{MWh} / \mathrm{MW}\end{array}$ & \\
\hline $\begin{array}{l}\text { Percentage of } \\
\text { generated solar } \\
\text { electricity fed to } \\
\text { battery }\end{array}$ & $\begin{array}{l}\text { High resource: } 25 \% \\
\text { Medium resource: } 31 \% \\
\text { Low resource: } 33 \%\end{array}$ & $\begin{array}{l}\text { Assumes a } 75 \% \text { discharge per day for a } 2- \\
\text { hour, 3-kW battery }\end{array}$ \\
\hline $\begin{array}{l}\text { Roundtrip energy } \\
\text { losses from } \\
\text { PV/battery/grid }\end{array}$ & $10 \%$ & \\
\hline $\begin{array}{l}\text { Roundtrip energy } \\
\text { losses from } \\
\text { grid/battery/grid }\end{array}$ & $8 \%$ & \\
\hline Charging cost & $\$ 0$ & $\begin{array}{l}\text { Battery charged solely by PV due to ITC } \\
\text { considerations }\end{array}$ \\
\hline O\&M (\$/kW/yr) & $\$ 39$ & $\begin{array}{l}\text { Assumes storage O\&M adds } \$ 10 / \mathrm{kW} \text {-yr to } \\
\text { PV costs }\end{array}$ \\
\hline $\begin{array}{l}\text { Annual PV } \\
\text { degradation }\end{array}$ & $0.70 \%$ & \\
\hline $\begin{array}{l}\text { Annual electricity } \\
\text { purchased from grid }\end{array}$ & 0 & \\
\hline System lifetime & 30 years & \\
\hline Inflation & $2.5 \%$ & \\
\hline
\end{tabular}


We use these inputs to calculate LCOSS as follows:

\section{Equation 1. LCoss formula}

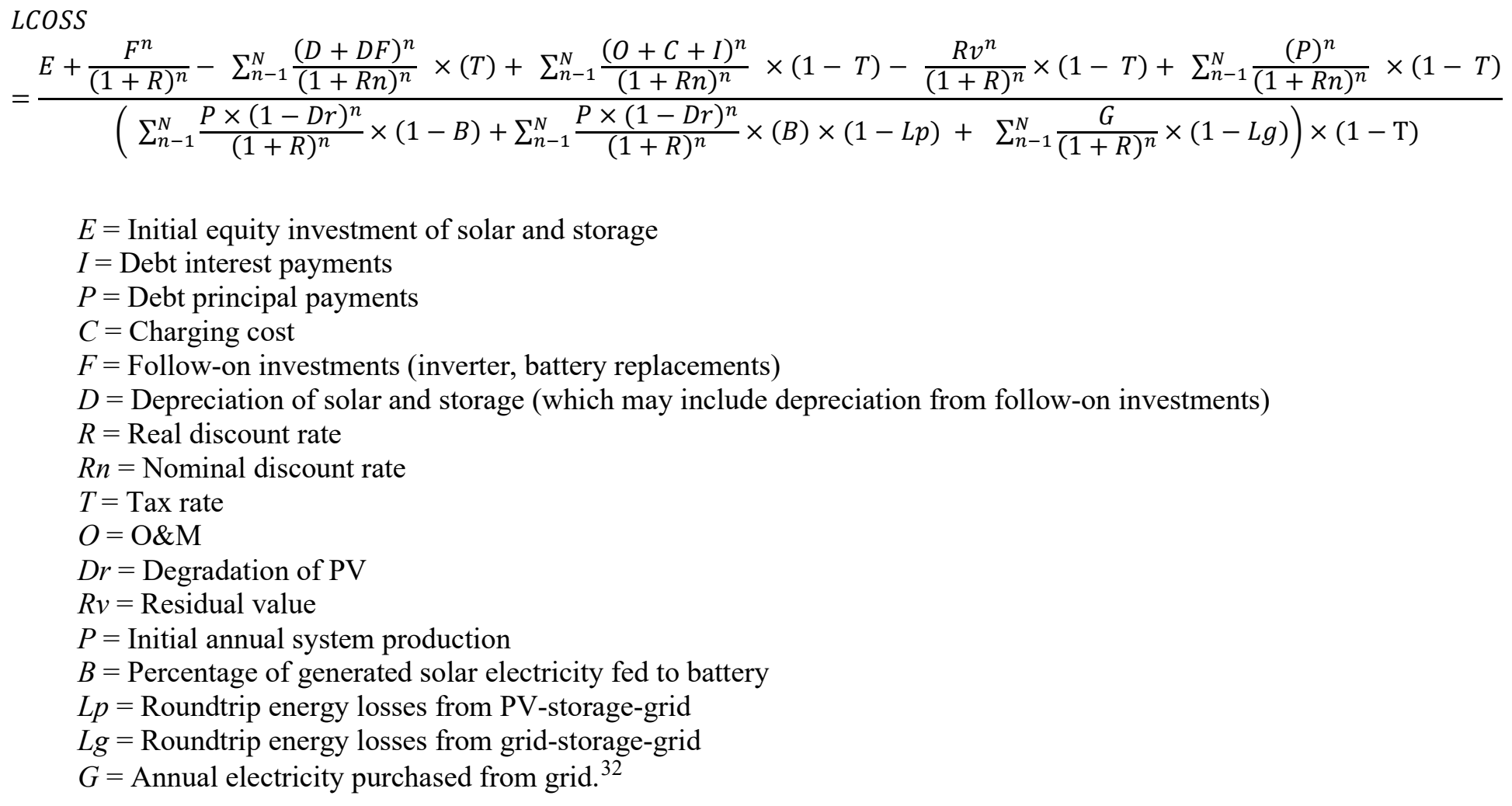

\footnotetext{
${ }^{32}$ If the ITC is claimed, we assume the initial investment is reduced by $30 \%$ and depreciation is reduced by $15 \%$. We assume projects can qualify as starting construction before 2020, allowing them to claim a 30\% ITC, instead of the $26 \%$ ITC for projects starting construction in 2020.
} 
Figure 39 shows the LCOSS for a residential AC-coupled PV $(7 \mathrm{~kW})$ plus storage $(3 \mathrm{~kW} / 6 \mathrm{kWh}$, 2-hour duration) system, as well as the LCOE of a 7-kW standalone PV system. LCOSS is calculated to be \$201/MWh without the federal ITC and \$124/MWh with the 30\% ITC for the PV-plus-storage system, with a medium resource for PV electricity production. ${ }^{33}$ The PV-plusstorage LCOSS is $\$ 74 / \mathrm{MWh}$ higher than the standalone-PV LCOE without the ITC, and \$47/MWh higher with a 30\% ITC.

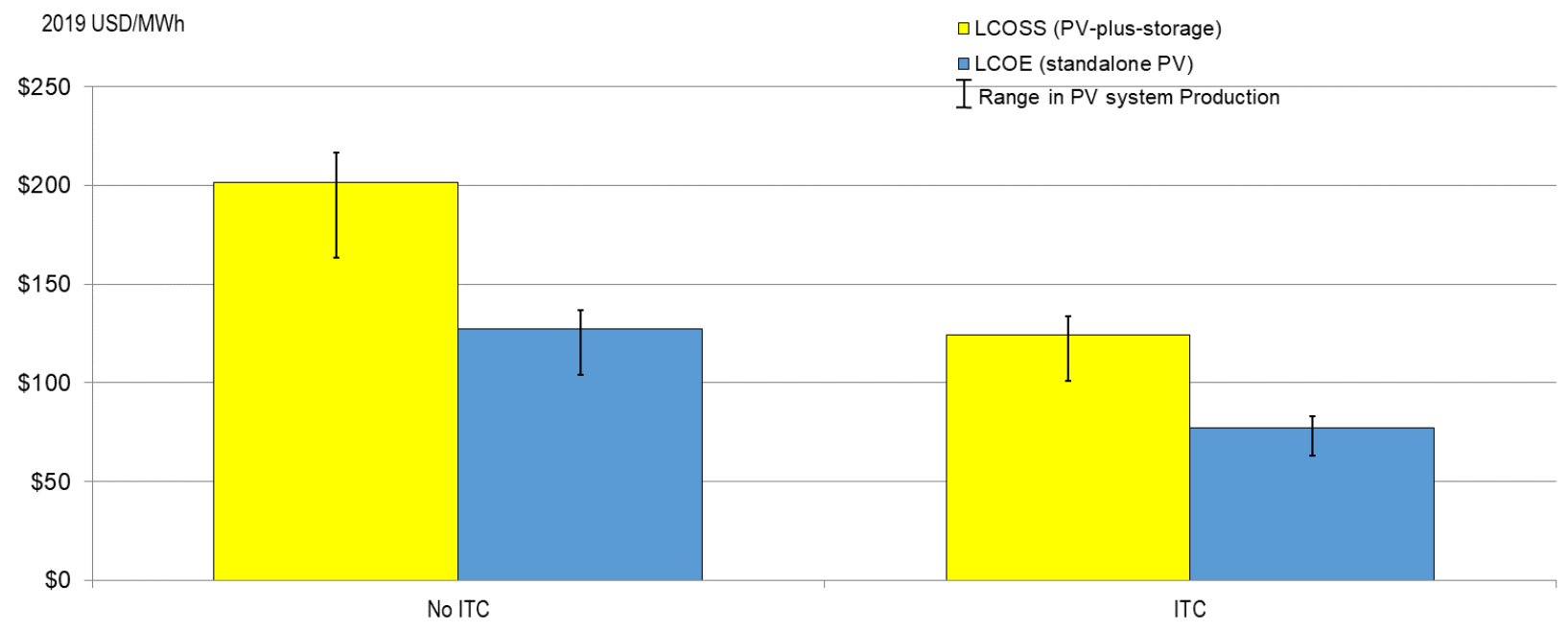

Figure 39. U.S. residential LCOSS for an AC-coupled PV (7 kW) plus storage ( 3 kW/6 kWh, 2-hour duration) system and LCOE for a 7-kW standalone PV system, Q1 2020

LCOSS is calculated for each scenario with a medium CF (representing Kansas City); LCOSS and LCOE ranges based on high and low CF assumptions; all other values remain the same.

\footnotetext{
${ }^{33} \mathrm{We}$ do not change the inputs and assumptions between the ITC and non-ITC cases, despite the fact that the inputs in the LCOSS calculation assume the owner of the PV-plus-storage system is operating the plant in such a way that they can claim the ITC on the storage equipment. In reality, an owner would likely operate a PV-plus-storage system differently without the ITC.
} 


\section{Commercial Storage and PV-plus-Storage Model}

To analyze component costs and system prices for commercial PV-plus-storage installed in Q1 2020, we adapt NREL's component- and system-level modeling approach for standalone PV in the same manner as we did for the residential PV-plus-storage system. This is the first year in which we analyzed commercial PV-plus-storage, and therefore we have no historical analysis from which to compare.

Customer preference for specific characteristics is based on several factors, including cost, load profile, and planned use of the system for load shifting (storing energy in one period for use in a later period). In general, customers who have loads with high peaks of short duration may desire a high-power (high-kW) battery capable of meeting the high peak. Customers who have flatter loads with lower peaks of longer duration may prefer a high-energy (high-kWh) battery capable of longer-duration energy discharge.

Sections 7.1 and 7.2 present the commercial storage and PV-plus-storage cost models, Section 7.3 shows the model outputs, and Section 7.4 benchmarks the LCOSS for a commercial PV-plusstorage system

\subsection{Commercial Li-Ion Standalone Storage Cost Model}

To reduce installation costs, some battery manufacturers may combine Li-ion battery cells, a battery management system, and the battery inverter in one compact unit (Sonnen Batterie 2018) as an AC battery. However, in this report, we focus on traditional DC batteries typically configured with the components shown in Figure 40 and Figure 41.

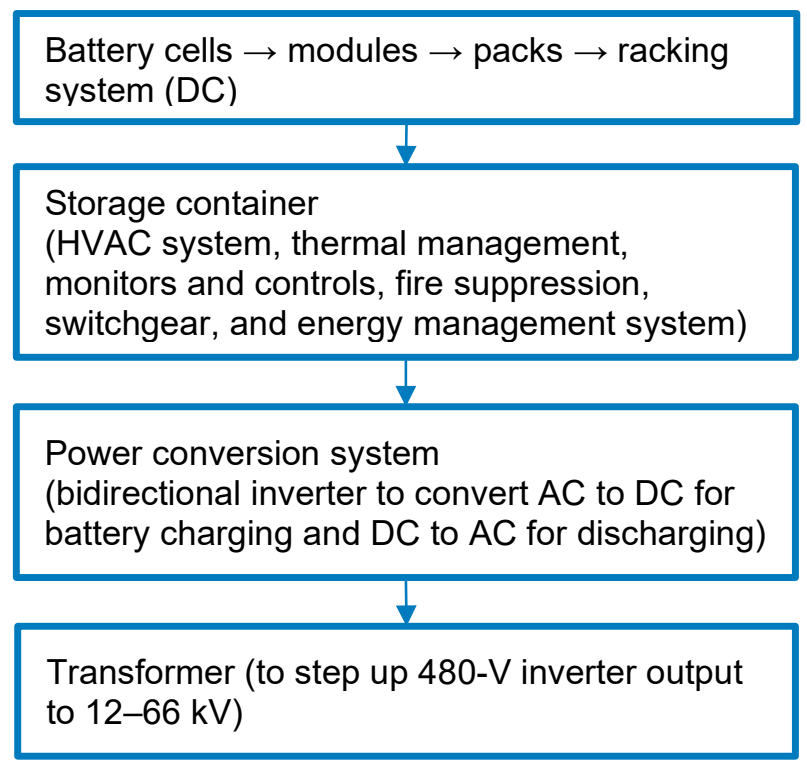

Figure 40. Traditional commercial and utility-scale Li-ion battery energy storage components HVAC = heating, ventilating, and air conditioning 


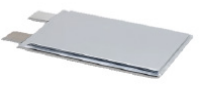

Battery Cell

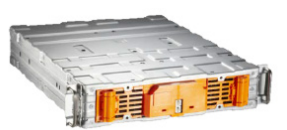

Battery Module

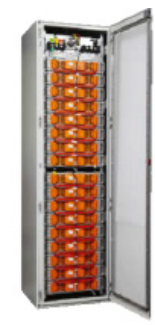

Battery Racks

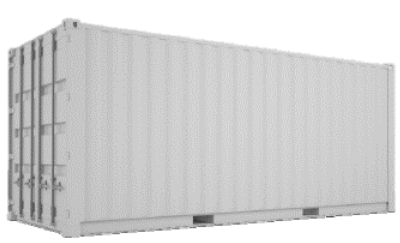

Battery

Container

\section{Figure 41. Battery system components}

Source: 2018 North American Generator Forum/Energy Systems Integration Group Workshop

Table 12 lists our model inputs and assumptions for a commercial energy storage system. We determine the battery size $\left(600 \mathrm{~kW}_{\mathrm{DC}}\right)^{34}$ using an inverter loading ratio of 1.3 and a $\mathrm{PV} /$ storage size ratio of 1.67, based on Denholm, Eichman, and Margolis (2017).

Table 12. Commercial Li-ion Energy Storage System: Model Inputs and Assumptions

\begin{tabular}{|c|c|c|c|}
\hline $\begin{array}{l}\text { Model } \\
\text { Component }\end{array}$ & Modeled Value & Description & Sources \\
\hline $\begin{array}{l}\text { Battery total } \\
\text { size }\end{array}$ & $600 \mathrm{kWDC}$ & Baseline case to match a 1-MW PV system & NREL 2020 \\
\hline $\begin{array}{l}\text { Battery size } \\
\text { per container }\end{array}$ & $\begin{array}{l}2.4 \mathrm{MWh} \text { per } 40-\mathrm{ft} \\
\text { container }\end{array}$ & 1 container & NREL 2020 \\
\hline $\begin{array}{l}\text { Li-ion battery } \\
\text { price }\end{array}$ & $\begin{array}{l}0.5 \text { hours: } \$ 242 / \mathrm{kWh} \\
1 \text { hour: } \$ 223 / \mathrm{kWh} \\
2 \text { hours: } \$ 198 / \mathrm{kWh} \\
4 \text { hours: } \$ 194 / \mathrm{kWh}\end{array}$ & Ex-factory gate (first buyer) prices & BNEF 2019b \\
\hline Duration & $0.5-4.0$ hours & Duration determines energy (MWh) & NREL 2020 \\
\hline $\begin{array}{l}\text { Battery central } \\
\text { inverter price }\end{array}$ & $\$ 0.06 / \mathrm{W}$ & Ex-factory gate (first buyer) prices & $\begin{array}{l}\text { Wood Mackenzie } \\
2019\end{array}$ \\
\hline Electrical BOS & $\$ 0.19 / \mathrm{W}$ & $\begin{array}{l}\text { Includes conduit, wiring, DC cable, energy } \\
\text { management system, switchgear, } \\
\text { transformer, and monitor and controls for } \\
\text { each container. Costs impacted by the } \\
\text { number of containers, transformers, and row } \\
\text { spacing }\end{array}$ & NREL 2020 \\
\hline Structural BOS & $\$ 0.10 / \mathrm{W}$ & $\begin{array}{l}\text { Includes foundation, battery containers, and } \\
\text { inverter house. Costs impactedby the number } \\
\text { of containers, inverters, transformers, and the } \\
\text { spacing between containers }\end{array}$ & NREL 2020 \\
\hline
\end{tabular}

\footnotetext{
${ }^{34}$ For a $1 \mathrm{MW}$ PV system with an inverter loading ratio of 1.3 and $\mathrm{PV} /$ storage size ratio of 1.67 , maximum deliverable power at point of interconnection is $1.37 \mathrm{MW}_{\mathrm{AC}}(1-\mathrm{MW} / 1.3+1 \mathrm{MW} / 1.67)$ for AC coupled systems and $770 \mathrm{~kW}_{\mathrm{AC}}(1 \mathrm{MW} / 1.3)$ for DC coupled systems.
} 


\begin{tabular}{|c|c|c|c|}
\hline $\begin{array}{l}\text { Model } \\
\text { Component }\end{array}$ & Modeled Value & Description & Sources \\
\hline \multirow[t]{2}{*}{$\begin{array}{l}\text { Installation } \\
\text { labor }\end{array}$} & $\begin{array}{l}\text { Electrician: } \$ 27.47 \\
\text { per hour }\end{array}$ & $\begin{array}{l}\text { National average modeled labor rate } \\
\text { assumes nonunionized labor }\end{array}$ & BLS 2019 \\
\hline & $\begin{array}{l}\text { Laborer: } \$ 18.17 \\
\text { per hour }\end{array}$ & & \\
\hline Sales tax & $\begin{array}{l}5 \% \text { (national } \\
\text { average) }\end{array}$ & Sales tax on the equipment & RSMeans 2017 \\
\hline $\begin{array}{l}\text { EPC overhead } \\
\text { and profit }\end{array}$ & $\begin{array}{l}8.67 \% \text { for equipment } \\
\text { and material; } 23 \%- \\
69 \% \text { for labor costs; } \\
\text { varies by system } \\
\text { size, labor activity, } \\
\text { and location }\end{array}$ & $\begin{array}{l}\text { Costs associated with EPC SG\&A, } \\
\text { warehousing, shipping, and logistics }\end{array}$ & NREL 2020 \\
\hline $\begin{array}{l}\text { Developer } \\
\text { cost: developer } \\
\text { overhead }\end{array}$ & $\begin{array}{l}6 \% \text { of total } \\
\text { installation cost }\end{array}$ & $\begin{array}{l}\text { Includes overhead expenses such as payroll, } \\
\text { facilities, travel, legal fees, administrative, } \\
\text { business development, finance, and other } \\
\text { corporate functions }\end{array}$ & NREL 2020 \\
\hline $\begin{array}{l}\text { Developer } \\
\text { cost: PII }\end{array}$ & $\$ 0.06 / \mathrm{W}$ & $\begin{array}{l}\text { Construction permits fee, interconnection } \\
\text { study, interconnection inspection, and } \\
\text { interconnection fee }\end{array}$ & NREL 2020 \\
\hline $\begin{array}{l}\text { Developer } \\
\text { cost: } \\
\text { contingency }\end{array}$ & $4 \%$ & Estimated as markup on the total EPC cost & NREL 2020 \\
\hline $\begin{array}{l}\text { Developer } \\
\text { cost: } \\
\text { EPC/developer } \\
\text { net profit }\end{array}$ & $5 \%$ & $\begin{array}{l}\text { Applies a percentage margin to all costs } \\
\text { including hardware, installation labor, EPC } \\
\text { overhead, and developer overhead }\end{array}$ & NREL 2020 \\
\hline
\end{tabular}

We use these inputs to calculate energy storage cost via the following equation ${ }^{35}$ : Energy storage installation cost $\left(\frac{\$}{k W h}\right)=$

Battery cost $\left(\frac{\$}{k W h}\right)+\frac{\text { Other cost components }(\$) \text { such as battery inverter and labor }}{\text { Storage system size }(k W) \times \text { Duration }(\text { hours })}$

Figure 42 and Table 13 show the resulting $\$ / \mathrm{kWh}$ costs for $600-\mathrm{kW}$ Li-ion energy storage systems, which vary from $\$ 469 / \mathrm{kWh}$ (4-hour duration) to $\$ 2,167 / \mathrm{kWh}(0.5$-hour duration). The battery cost accounts for $41 \%$ of total system cost in the 4 -hour system, but only $11 \%$ in the 0.5 hour system. At the same time, non-battery cost categories account for an increasing proportion of the system cost as duration declines.

\footnotetext{
${ }^{35}$ This equation is only for the energy storage installation cost calculation. For levelized cost of storage (LCOS), the equation would be different. LCOS is not covered in this report.
} 


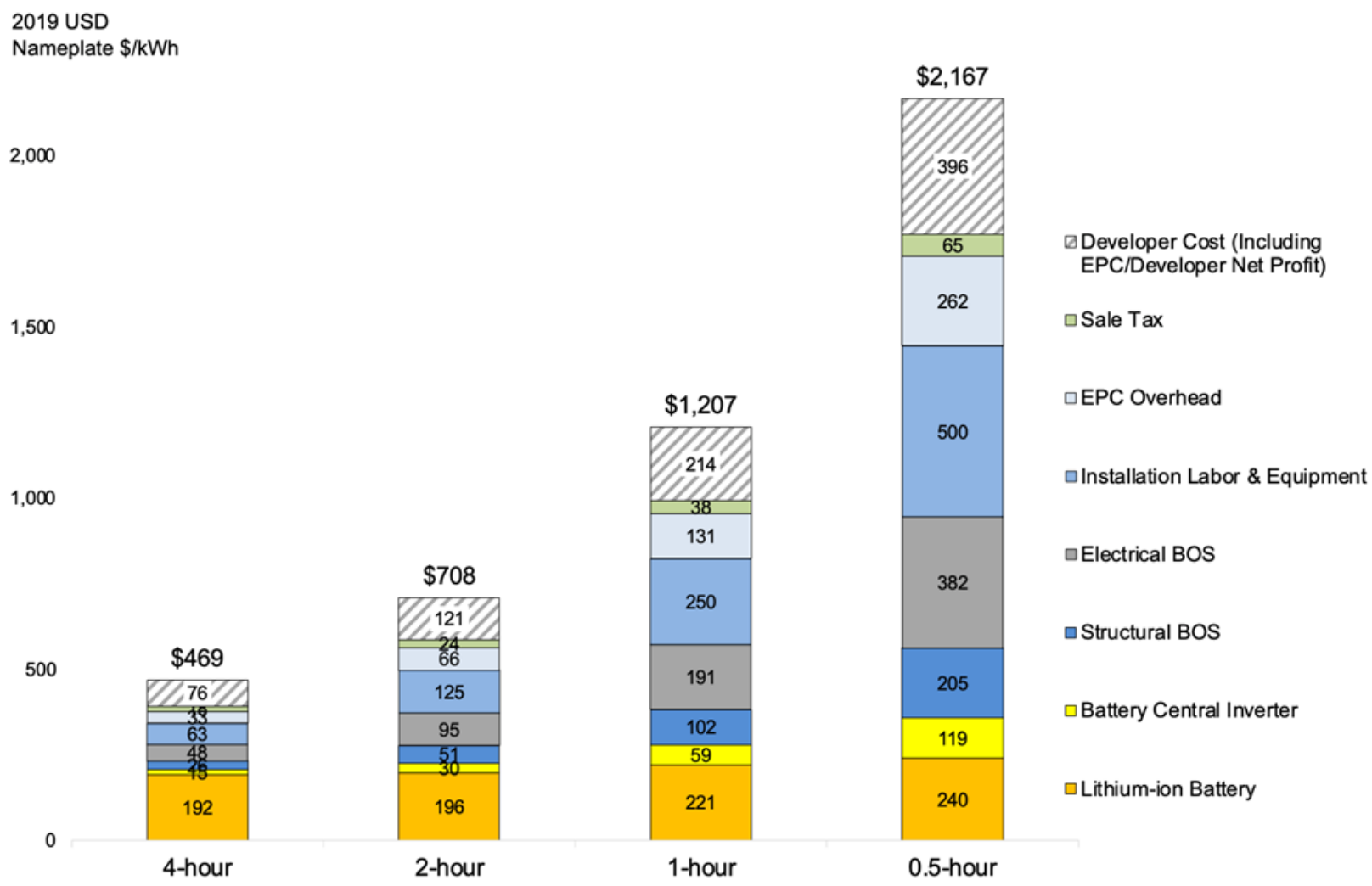

Figure 42. U.S. commercial Li-ion battery standalone storage costs for durations of $0.5-4.0$ hours (600 kWDC), Q1 2020 
Table 13. Detailed Cost Breakdown for a 600-kW U.S. Commercial Li-ion Standalone Storage System with Durations of 0.5-4 hours

\begin{tabular}{|c|c|c|c|c|c|c|c|c|c|c|c|c|}
\hline \multirow[b]{2}{*}{ Model Component } & \multicolumn{3}{|c|}{$\begin{array}{c}\text { 600-kW, 4-hour Duration, } \\
\text { 2,400-kWh }\end{array}$} & \multicolumn{3}{|c|}{$\begin{array}{c}\text { 600-kW, 2-hour Duration, } \\
\text { 1,200-kWh }\end{array}$} & \multicolumn{3}{|c|}{$\begin{array}{c}\text { 600-kW, 1-hour Duration, } 600- \\
\text { kWh }\end{array}$} & \multicolumn{3}{|c|}{$\begin{array}{l}\text { 600-kW, 0.5-hour } \\
\text { Duration, 300-kWh }\end{array}$} \\
\hline & $\begin{array}{l}\text { Total } \\
\text { Cost }(\$)\end{array}$ & $\$ / k W h$ & $\$ / W$ & $\begin{array}{l}\text { Total } \\
\text { Cost }(\$)\end{array}$ & $\$ / k W h$ & $\$ / \mathbf{W}$ & $\begin{array}{c}\text { Total } \\
\text { Cost }(\$)\end{array}$ & $\$ / \mathbf{k W h}$ & $\$ / \mathbf{W}$ & $\begin{array}{l}\text { Total } \\
\text { Cost }(\$)\end{array}$ & $\$ / k W h$ & $\$ / W$ \\
\hline Li-ion battery & 465,600 & 192 & 0.78 & 237,600 & 196 & 0.40 & 133,800 & 221 & 0.22 & 72,600 & 240 & 0.12 \\
\hline Battery central inverter & 36,000 & 15 & 0.06 & 36,000 & 30 & 0.06 & 36,000 & 59 & 0.06 & 36,000 & 119 & 0.06 \\
\hline Structural BOS & 62,012 & 26 & 0.10 & 62,012 & 51 & 0.10 & 62,012 & 102 & 0.10 & 62,012 & 205 & 0.10 \\
\hline Electrical BOS & 115,618 & 48 & 0.19 & 115,618 & 95 & 0.19 & 115,618 & 191 & 0.19 & 115,618 & 382 & 0.19 \\
\hline Installation labor \& equipment & 151,596 & 63 & 0.25 & 151,596 & 125 & 0.25 & 151,596 & 250 & 0.25 & 151,596 & 500 & 0.25 \\
\hline EPC overhead & 79,475 & 33 & 0.13 & 79,475 & 66 & 0.13 & 79,475 & 131 & 0.13 & 79,475 & 262 & 0.13 \\
\hline Sales tax & 42,432 & 18 & 0.07 & 29,208 & 24 & 0.05 & 23,188 & 38 & 0.04 & 19,638 & 65 & 0.03 \\
\hline$\sum E P C$ cost & 952,734 & 393 & 1.59 & 711,510 & 587 & 1.19 & 601,689 & 993 & 1.00 & 536,940 & 1,772 & 0.89 \\
\hline Permitting fee & 7,507 & 3 & 0.01 & 7,507 & 6 & 0.01 & 7,507 & 12 & 0.01 & 7,507 & 25 & 0.01 \\
\hline Interconnection fee & 27,846 & 11 & 0.05 & 27,846 & 23 & 0.05 & 27,846 & 46 & 0.05 & 27,846 & 92 & 0.05 \\
\hline Contingency & 38,455 & 16 & 0.06 & 28,806 & 24 & 0.05 & 24,414 & 40 & 0.04 & 21,824 & 72 & 0.04 \\
\hline Developer overhead & 57,683 & 24 & 0.10 & 43,209 & 36 & 0.07 & 36,620 & 60 & 0.06 & 32,735 & 108 & 0.05 \\
\hline EPC/developer profit & 52,836 & 22 & 0.09 & 39,569 & 33 & 0.07 & 33,529 & 55 & 0.06 & 29,967 & 99 & 0.05 \\
\hline$\Sigma$ Developer cost & 184,327 & 76 & 0.31 & 146,937 & 121 & 0.24 & 129,915 & 214 & 0.22 & 119,879 & 396 & 0.20 \\
\hline $\begin{array}{l}\sum \text { Total energy storage } \\
\text { system cost }\end{array}$ & $1,137,060$ & 469 & 1.90 & 858,447 & 708 & 1.43 & 731,604 & 1,207 & 1.22 & 656,818 & 2,167 & 1.09 \\
\hline
\end{tabular}




\subsection{Commercial PV-plus-Storage System Cost Model}

We model a 1-MW commercial fixed-tilt ground-mount PV plus 600-kW storage system, with 0.5 hours $(300 \mathrm{kWh}), 1$ hour $(600 \mathrm{kWh}), 2$ hours $(1.2 \mathrm{MWh})$, and 4 hours $(2.4 \mathrm{MWh})$ of storage, using the same PV assumptions we used with our standalone PV system. Figure 43 provides a schematic of typical DC- and AC-coupled PV systems with battery back-up. Table 5, Table 12, and Table 14 present modeling inputs and assumptions.

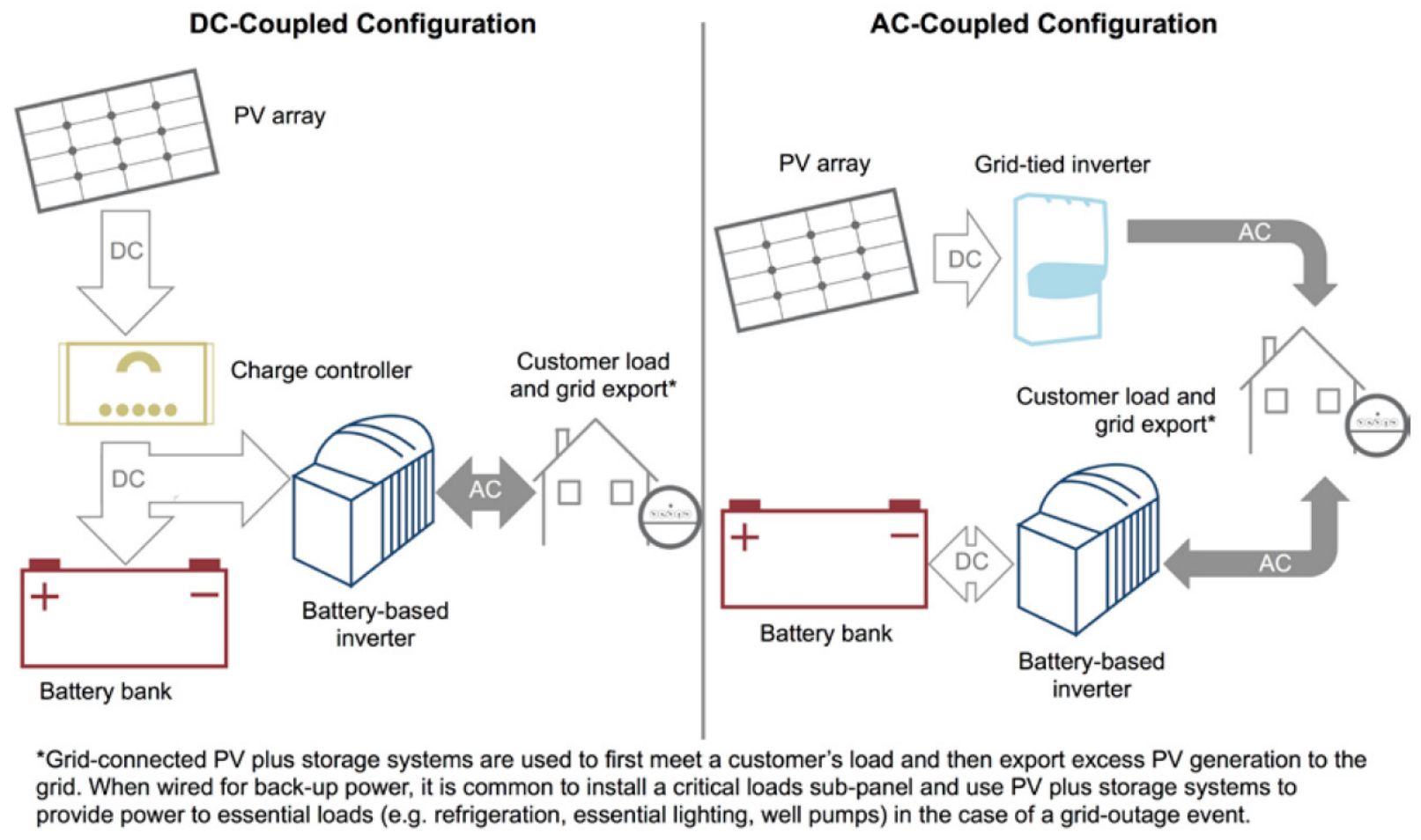

Figure 43. Modeled DC- and AC-coupled system configurations

Figure is simplified for illustrative purposes.

Table 14. Changes to Commercial PV and Storage Models When PV and Storage Are Combined

\begin{tabular}{|c|c|c|}
\hline Category & Modeled Value & Description \\
\hline Electrical BOS & $\begin{array}{l}90 \% \text { of the combined BOS costs for PV } \\
\text { and battery standalone systems }\end{array}$ & Duplicative parts are removed \\
\hline $\begin{array}{l}\text { Installation } \\
\text { labor }\end{array}$ & $\begin{array}{l}90 \% \text { of the combined BOS costs for PV } \\
\text { and battery standalone systems }\end{array}$ & Duplicative work is removed \\
\hline $\begin{array}{l}\text { Sales and } \\
\text { marketing }\end{array}$ & $\begin{array}{l}20 \text { hours more time for DC system, and } \\
32 \text { hours more for AC system, per } \\
\text { closed sale, associated with selling a } \\
\text { PV system with storage }\end{array}$ & $\begin{array}{l}\text { Additional explanation, calculations, and } \\
\text { a lower close rate; also, the AC system } \\
\text { requires more customer site assessment }\end{array}$ \\
\hline
\end{tabular}

\subsection{Commercial Model Output}

Figure 44 summarizes our model results for several system types and configurations:

- Standalone 1-MW commercial fixed-tilt ground-mount PV system (\$1.59 million) 
- Standalone 600-kW/2.4-MWh, 4-hour-duration energy storage system ( $\$ 1.13$ million)

- Colocated DC-coupled PV (1-MW) plus storage (600 kW/2.4 MWh, 4-hour duration) system (\$2.13 million)

- Colocated AC-coupled PV (1-MW) plus storage (600 kW/2.4 MWh, 4-hour duration) system (\$2.07 million)

- PV (1-MW) plus storage (600 kW/2.4 MWh, 4-hour duration) system with PV and storage components sited in different locations ( $\$ 2.72$ million).

Table 15 shows detailed costs for the three PV-plus-storage configurations. Colocating the PV and storage subsystems produces cost savings by reducing costs related to site preparation, permitting, interconnection, installation labor, hardware (via sharing of hardware such as switchgears, transformers, and controls), overhead, and profit. The cost of the colocated ACcoupled system is $24 \%$ lower than the cost of the system with PV and storage sited separately.

Using DC-coupling rather than AC-coupling results in a 2.8\% higher total cost, which is the net result of cost differences between DC-coupling and AC-coupling in the categories of solar inverter, structural BOS, electrical BOS, labor, EPC and developer overhead, sales tax, contingency, and profit. For an actual project, however, cost savings may not be the only factor in choosing DC- or AC-coupling. Additional factors - such as retrofit considerations, system performance (including energy loss due to clipping), design flexibility, and O\&M—should be considered.

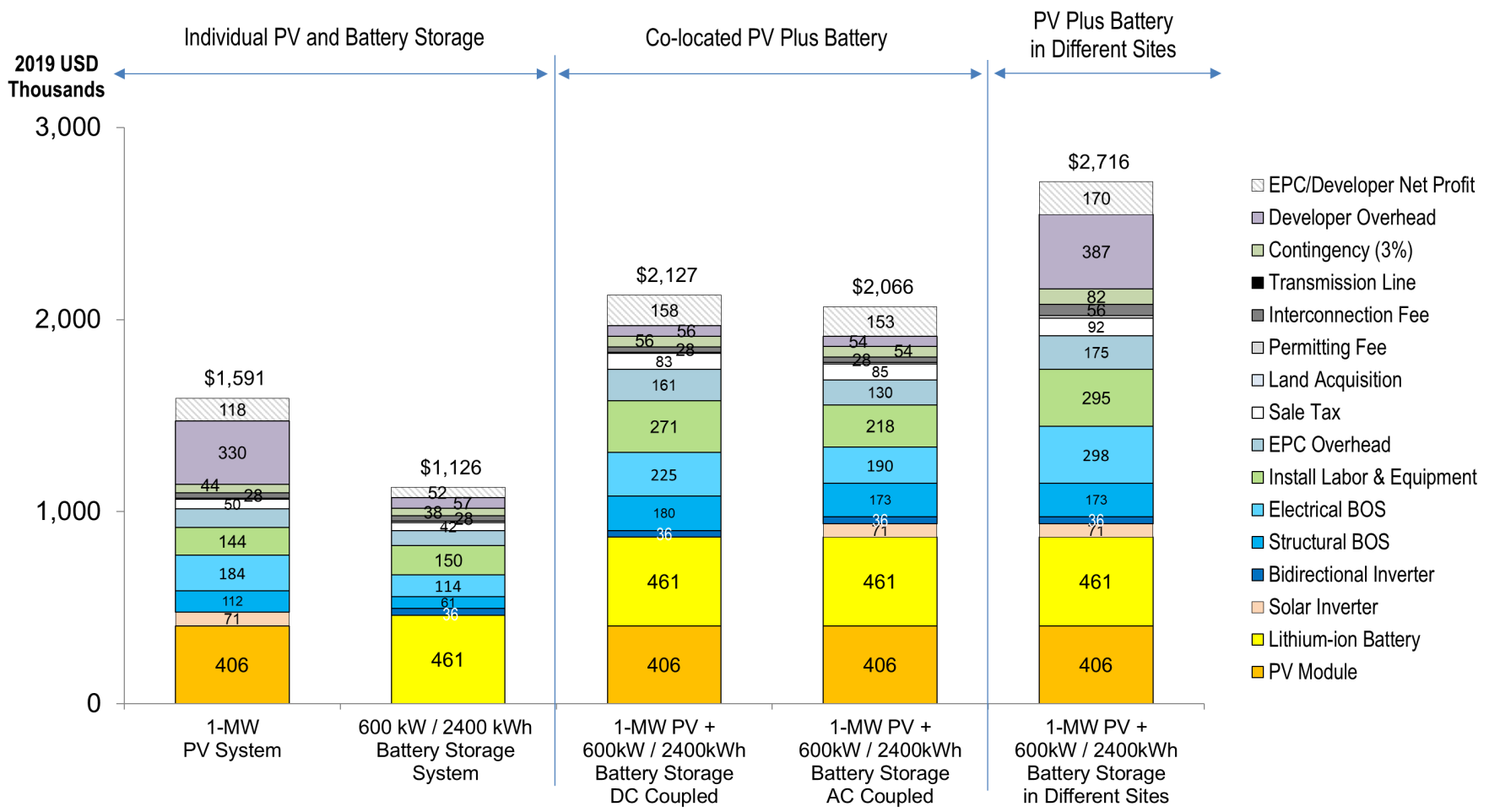

Figure 44. Cost benchmarks for commercial PV-plus-storage systems (4-hour duration) in different sites and the same site (DC-coupled and AC-coupled cases), Q1 2020 
Table 15. Detailed Cost Breakdown for Commercial Li-ion PV-Plus-Storage Systems

\begin{tabular}{|c|c|c|c|}
\hline Model Component & $\begin{array}{l}\text { 1-MW PV Plus } \\
600-k W / 2.4-M W h \\
\text { Battery, DC- } \\
\text { Coupled, Colocated }\end{array}$ & $\begin{array}{l}\text { Total Cost } \\
\text { 1-MW PV Plus } \\
600-k W / 2.4-M W h \\
\text { Battery, AC- } \\
\text { Coupled, Colocated }\end{array}$ & $\begin{array}{l}\text { 1-MW PV Plus } \\
600-k W / 2.4-M W h \\
\text { Battery, in } \\
\text { Different Sites }\end{array}$ \\
\hline PV module & $\$ 405,877$ & $\$ 405,877$ & $\$ 405,877$ \\
\hline Li-ion battery & $\$ 460,917$ & $\$ 460,917$ & $\$ 460,917$ \\
\hline Solar inverter & - & $\$ 71,347$ & $\$ 71,347$ \\
\hline Bidirectional inverter & $\$ 35,638$ & $\$ 35,638$ & $\$ 35,638$ \\
\hline Structural BOS & $\$ 179,759$ & $\$ 173,284$ & $\$ 173,285$ \\
\hline Electrical BOS & $\$ 225,088$ & $\$ 190,036$ & $\$ 298,378$ \\
\hline Installation labor \& equipment & $\$ 271,097$ & $\$ 217,553$ & $\$ 294,560$ \\
\hline EPC overhead & $\$ 161,386$ & $\$ 129,511$ & $\$ 175,354$ \\
\hline Sales tax & $\$ 82,924$ & $\$ 84,816$ & $\$ 91,688$ \\
\hline$\sum E P C$ cost & $\$ 1,822,686$ & $\$ 1,768,978$ & $\$ 2,007,044$ \\
\hline Land acquisition & 0 & 0 & 0 \\
\hline Permitting fee & $\$ 7,507$ & $\$ 7,657$ & $\$ 15,014$ \\
\hline Interconnection fee & $\$ 27,846$ & $\$ 28,403$ & $\$ 55,691$ \\
\hline Transmission line & 0 & 0 & 0 \\
\hline Contingency & $\$ 55,741$ & $\$ 54,151$ & $\$ 82,038$ \\
\hline Developer overhead & $\$ 55,741$ & $\$ 54,151$ & $\$ 386,876$ \\
\hline EPC/developer profit & $\$ 157,562$ & $\$ 153,067$ & $\$ 170,144$ \\
\hline$\sum$ Developer cost & $\$ 304,396$ & $\$ 297,429$ & $\$ 709,407$ \\
\hline $\begin{array}{l}\sum \text { Total energy storage } \\
\text { system cost }\end{array}$ & $\$ 2,127,082$ & $\$ 2,066,408$ & $\$ 2,716,451$ \\
\hline
\end{tabular}

\subsection{Commercial Levelized Cost of Solar-plus-Storage}

For this year's benchmark report, we calculate the LCOSS for our commercial PV-plus-storage system, with the same formula and caveats as we use for our residential PV-plus-storage system (see Section 6.5). Table 16 lists our model inputs and assumptions for the commercial PV-plusstorage system. 
Table 16. Commercial LCOSS Inputs and Assumptions

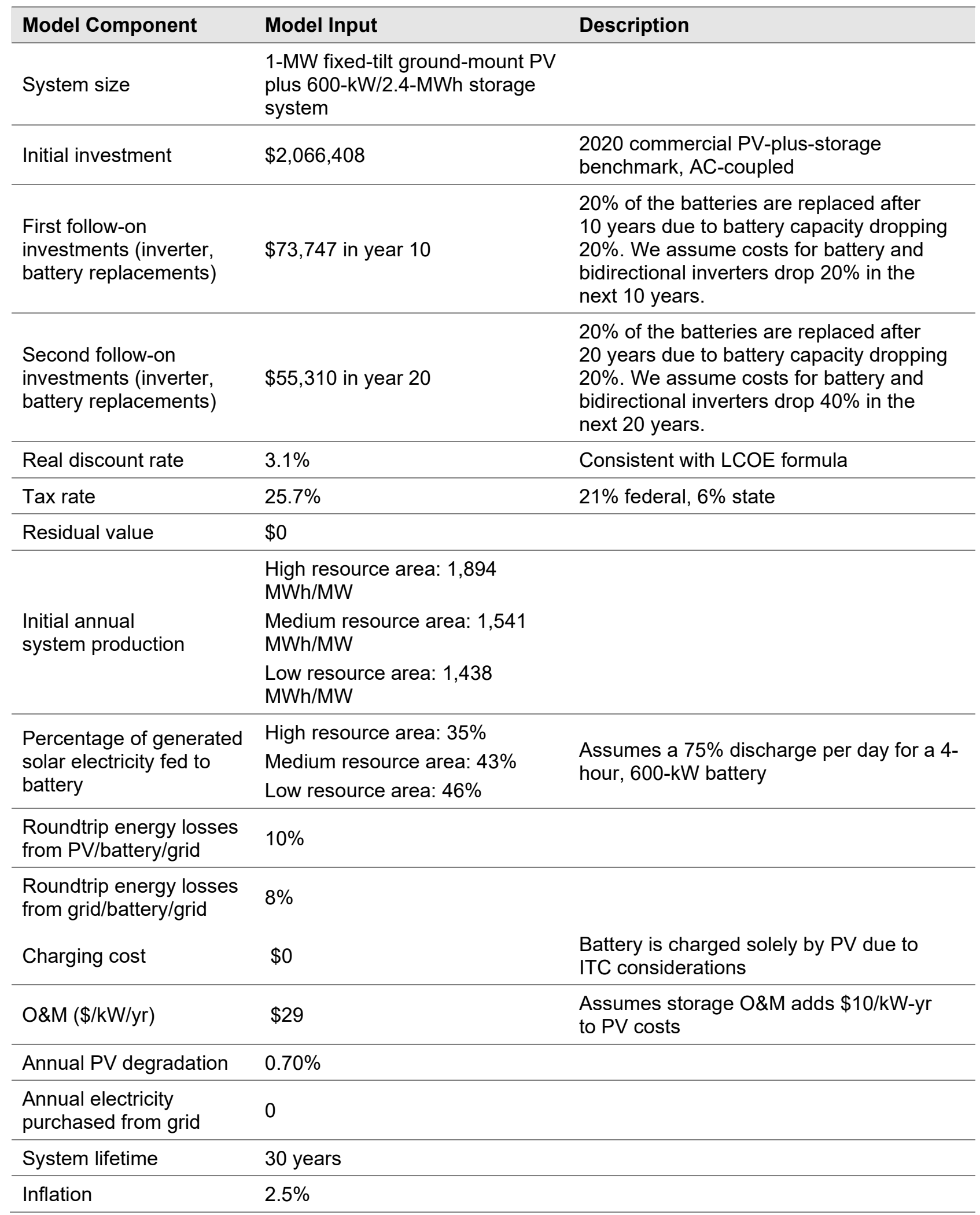


We use these inputs to calculate LCOSS via Equation 1. Figure 45 shows the resulting LCOSS for a commercial AC-coupled fixed-tilt ground-mount PV (1 MW) plus storage $(600 \mathrm{~kW} / 2.4$ MWh, 4-hour duration) system, as well as the LCOE of a 1-MW fixed-tilt ground-mount standalone PV system. LCOSS is calculated to be $\$ 113 / \mathrm{MWh}$ without the federal ITC and $\$ 73 / \mathrm{MWh}$ with the $30 \%$ ITC for commercial PV-plus-storage, with a medium resource for PV electricity production. The PV-plus-storage LCOSS is $\$ 37 / \mathrm{MWh}$ higher than the standalone-PV LCOE without the ITC, and \$27/MWh higher with a 30\% ITC.

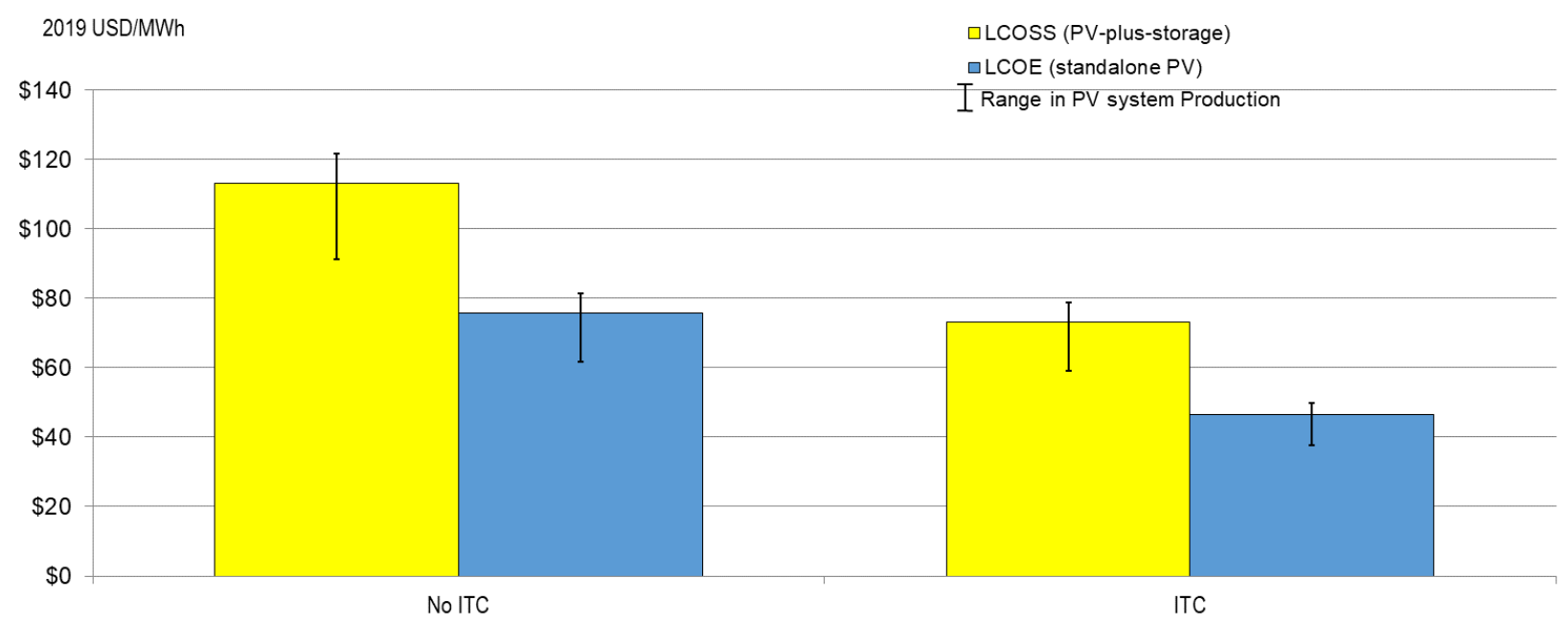

Figure 45. U.S. commercial LCOSS for an AC-coupled PV (1 MW) plus storage (600 kW/2.4 MWh, 4hour duration) system and LCOE for a 1-MW standalone PV system, Q1 2020

LCOSS is calculated for each scenario with a medium CF (representing Kansas City); LCOSS and LCOE ranges based on high and low CF assumptions; all other values remain the same. 


\section{Utility-Scale Storage and PV-plus-Storage Model}

Figure 46 shows the detailed bottom-up cost structure of our standalone utility-scale storage model, which uses a structure similar to our previously developed PV cost model (Fu et al. 2015, 2016, 2017; Fu, Feldman, and Margolis 2018; Fu, Remo, and Margolis 2018). Total system upfront capital costs are broken into EPC costs and developer costs. EPC non-hardware, or "soft," costs are driven by labor rates and labor productivities. We adapt engineering-design and cost-estimating models from RSMeans (2017) to determine the EPC hardware costs (including module/battery racking, mounting, wiring, containerization, and foundation) and related EPC soft costs (including related labor and equipment hours required in any given U.S. location).

Sections 8.1 and 8.2 present the utility-scale storage and PV-plus-storage cost models, Section 8.3 shows the model outputs, Section 8.4 compares PV-plus-storage benchmark trends over time, and Section 8.5 benchmarks the LCOSS for a utility-scale PV-plus-storage system.

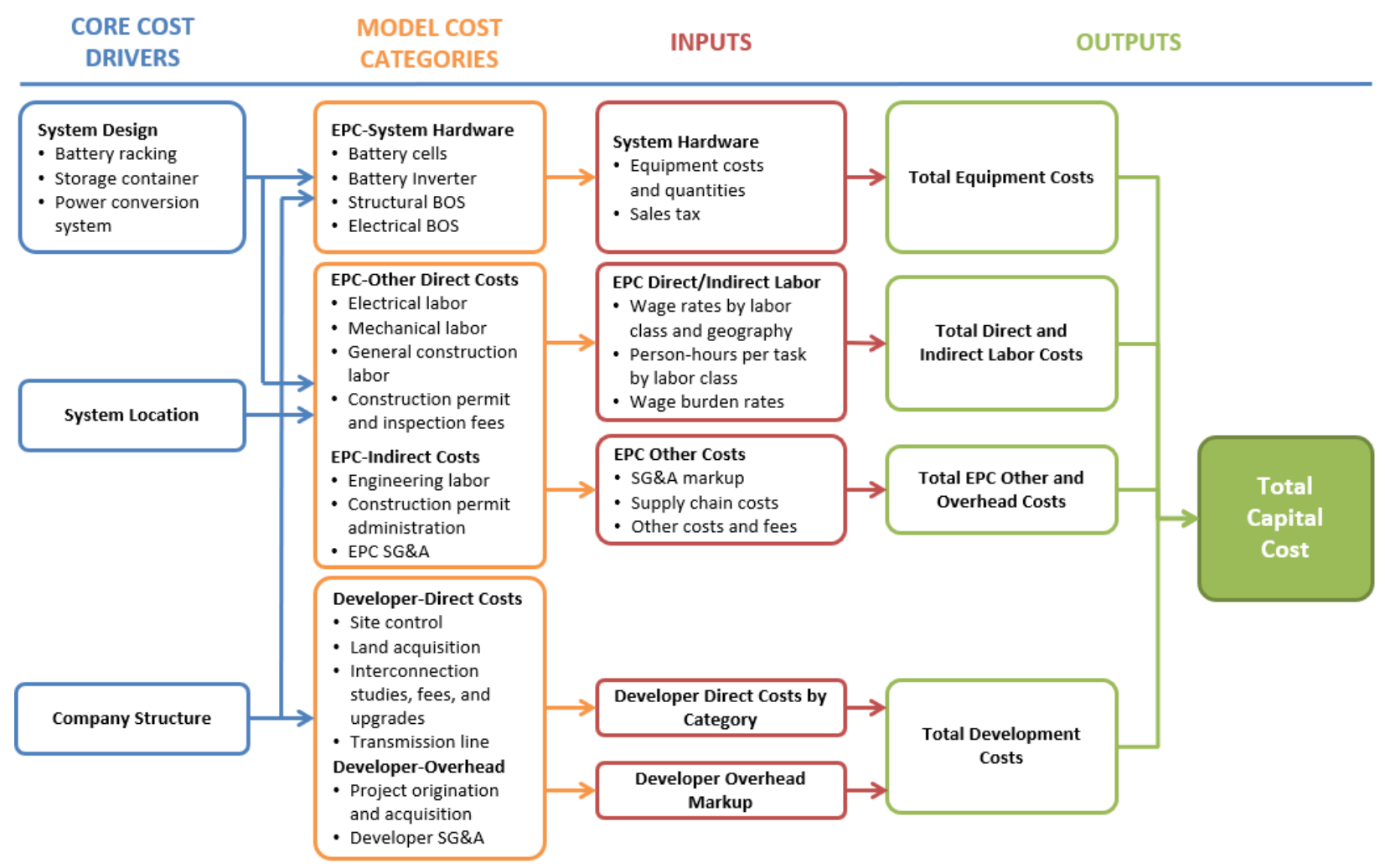

Figure 46. Structure of the bottom-up cost model for utility-scale standalone storage systems

\subsection{Utility-Scale Li-Ion Standalone Storage Cost Model}

The major storage components we model for utility-scale standalone storage systems are the same as those summarized in Figure 40 and Figure 41 for the commercial standalone storage model. Table 17 lists our model inputs and assumptions for such a utility-scale energy storage 
system. We determine the battery size $\left(60 \mathrm{MW}_{\mathrm{DC}}\right)^{36} \mathrm{using}$ an inverter loading ratio of 1.3 and a PV/storage size ratio of 1.67, based on Denholm, Eichman, and Margolis (2017).

Table 17. Utility-Scale Li-ion Energy Storage System: Model Inputs and Assumptions

\begin{tabular}{|c|c|c|c|}
\hline $\begin{array}{l}\text { Model } \\
\text { Component }\end{array}$ & Modeled Value & Description & Source \\
\hline $\begin{array}{l}\text { Battery total } \\
\text { size }\end{array}$ & $60 \mathrm{MW} D \mathrm{DC}$ & $\begin{array}{l}\text { Baseline case to match a } 100-\mathrm{MW} \\
\text { PV system }\end{array}$ & NREL 2020 \\
\hline $\begin{array}{l}\text { Battery size } \\
\text { per container }\end{array}$ & $\begin{array}{l}2.5 \mathrm{MWh} \text { per } 40-\mathrm{ft} \\
\text { container }\end{array}$ & $\begin{array}{l}\text { Assumption to compute the number of } \\
\text { containers }\end{array}$ & NREL 2020 \\
\hline $\begin{array}{l}\text { Li-ion battery } \\
\text { price }\end{array}$ & $\begin{array}{l}0.5 \text { hours: } \$ 242 / \mathrm{kWh} \\
1 \text { hour: } \$ 223 / \mathrm{kWh} \\
2 \text { hours: } \$ 198 / \mathrm{kWh} \\
4 \text { hours: } \$ 194 / \mathrm{kWh}\end{array}$ & Ex-factory gate (first buyer) prices & BNEF 2019b \\
\hline Duration & $0.5-4.0$ hours & Duration determines energy (MWh) & NREL 2020 \\
\hline $\begin{array}{l}\text { Battery central } \\
\text { inverter price }\end{array}$ & $\$ 0.06 / \mathrm{W}$ & Ex-factory gate (first buyer) prices & $\begin{array}{l}\text { Wood Mackenzie } \\
2019\end{array}$ \\
\hline Inverter size & $2.5 \mathrm{MW}$ per inverter & $\begin{array}{l}\text { Used to determine the number of battery } \\
\text { inverters }\end{array}$ & NREL 2020 \\
\hline Electrical BOS & $\$ 0.07-\$ 0.14 / \mathrm{W}$ & $\begin{array}{l}\text { Includes conduit, wiring, DC cable, energy } \\
\text { management system, switchgear, } \\
\text { transformer, and monitor and controls for } \\
\text { each container. Determined by the number } \\
\text { of containers, transformers, and row } \\
\text { spacing. }\end{array}$ & NREL 2020 \\
\hline Structural BOS & $\$ 0.01-\$ 0.05 / \mathrm{W}$ & $\begin{array}{l}\text { Includes foundation, battery containers, and } \\
\text { inverter house. Determined by the number } \\
\text { of containers, inverters, transformers, and } \\
\text { the spacing between containers. }\end{array}$ & NREL 2020 \\
\hline \multirow[t]{2}{*}{$\begin{array}{l}\text { Installation } \\
\text { labor }\end{array}$} & $\begin{array}{l}\text { Electrician: } \$ 27.47 \\
\text { per hour }\end{array}$ & $\begin{array}{l}\text { National average modeled labor rate } \\
\text { assumes nonunionized labor }\end{array}$ & BLS 2019 \\
\hline & $\begin{array}{l}\text { Laborer: } \$ 18.17 \\
\text { per hour }\end{array}$ & & \\
\hline Sales tax & $\begin{array}{l}5 \% \text { (national } \\
\text { average) }\end{array}$ & Sales tax on the equipment & RSMeans 2017 \\
\hline $\begin{array}{l}\text { EPC overhead } \\
\text { and profit }\end{array}$ & $\begin{array}{l}8.67 \% \text { for equipment } \\
\text { and material; } 23 \%- \\
69 \% \text { for labor costs; } \\
\text { varies by system } \\
\text { size, and labor } \\
\text { activity }\end{array}$ & $\begin{array}{l}\text { Costs associated with EPC SG\&A, } \\
\text { warehousing, shipping, and logistics }\end{array}$ & NREL 2020 \\
\hline
\end{tabular}

\footnotetext{
${ }^{36}$ For a 100-MW PV system with an inverter loading ratio of 1.3 and $\mathrm{PV} /$ storage size ratio of 1.67 , maximum deliverable power at point of interconnection is $137 \mathrm{MW}_{\mathrm{AC}}(100 \mathrm{MW} / 1.3+100 \mathrm{MW} / 1.67)$ for AC coupled systems and $77 \mathrm{MW}_{\mathrm{AC}}(100 \mathrm{MW} / 1.3)$ for DC coupled systems.
} 


\begin{tabular}{|c|c|c|c|}
\hline $\begin{array}{l}\text { Model } \\
\text { Component }\end{array}$ & Modeled Value & Description & Source \\
\hline $\begin{array}{l}\text { Developer } \\
\text { cost: developer } \\
\text { overhead }\end{array}$ & $\begin{array}{l}3 \% \text { of total } \\
\text { installation cost }\end{array}$ & $\begin{array}{l}\text { Includes overhead expenses such as } \\
\text { payroll, facilities, travel, legal fees, } \\
\text { administrative, business development, } \\
\text { finance, and other corporate functions }\end{array}$ & NREL 2020 \\
\hline $\begin{array}{l}\text { Developer } \\
\text { cost: PII }\end{array}$ & $\$ 0.03 / \mathrm{W}$ & $\begin{array}{l}\text { Construction permits fee, interconnection } \\
\text { study, interconnection inspection, and } \\
\text { interconnection fee }\end{array}$ & NREL $(2020$ \\
\hline $\begin{array}{l}\text { Developer } \\
\text { cost: } \\
\text { contingency }\end{array}$ & $3 \%$ & Estimated as markup on the total EPC cost & NREL 2020) \\
\hline $\begin{array}{l}\text { Developer } \\
\text { cost: } \\
\text { EPC/developer } \\
\text { net profit }\end{array}$ & $5 \%$ & $\begin{array}{l}\text { Applies a percentage margin to all costs } \\
\text { including hardware, installation labor, EPC } \\
\text { overhead, and developer overhead }\end{array}$ & NREL 2020 \\
\hline
\end{tabular}

We use these inputs to calculate energy storage cost via the following equation ${ }^{37}$ : Energy storage installation cost $\left(\frac{\$}{k W h}\right)=$

Battery cost $\left(\frac{\$}{k W h}\right)+\frac{\text { Other cost components }(\$) \text { such as battery inverter and labor }}{\text { Storage system size }(k W) \times \text { Duration }(\text { hours })}$

Figure 47 and Table 18 show the resulting costs for 60-MW Li-ion energy storage systems, which vary from $\$ 341 / \mathrm{kWh}$ (4-hour duration) to $\$ 845 / \mathrm{kWh}$ (0.5-hour duration). While the perenergy-unit battery cost increases as system duration decreases, the total battery cost — and the proportion of the cost attributed to the battery-decrease as system duration decreases. For example, the battery cost accounts for $56 \%$ of total system cost in the 4-hour system, but only $28 \%$ in the 0.5 -hour system. At the same time, non-battery cost categories account for an increasing proportion of the system cost as duration declines.

\footnotetext{
${ }^{37}$ This equation is only for the energy storage installation cost calculation. For LCOS, the equation would be different. LCOS is not covered in this report.
} 


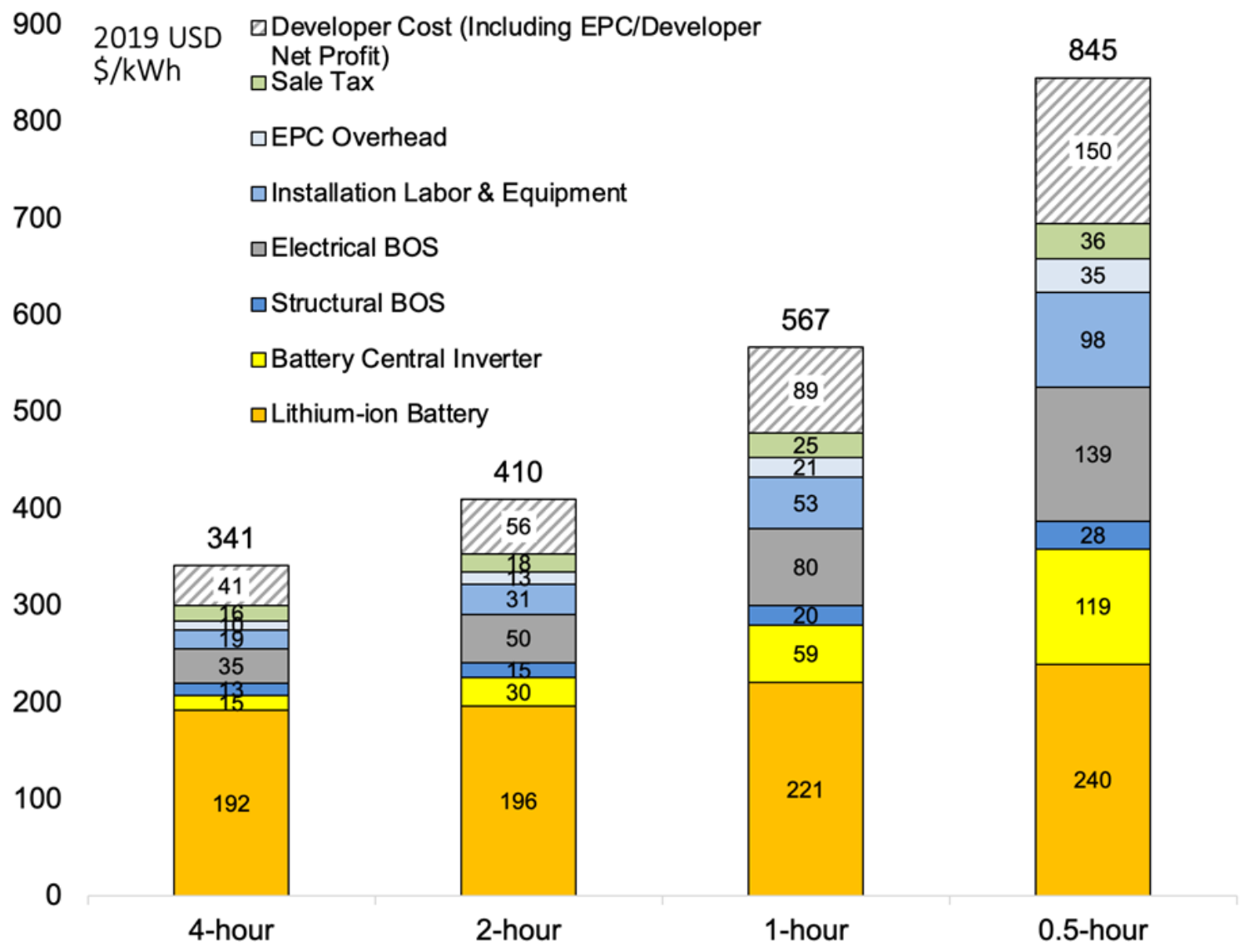

Figure 47. U.S. utility-scale Li-ion battery standalone storage costs for durations of $0.5-4.0$ hours (60 MW $\mathrm{DC}), \mathrm{Q} 12020$ 
Table 18. Detailed Cost Breakdown for a 60-MW U.S. Utility-Scale Li-ion Standalone Storage System with Durations of 0.5-4 hours

\begin{tabular}{|c|c|c|c|c|c|c|c|c|c|c|c|c|}
\hline \multirow[b]{2}{*}{ Model Component } & \multicolumn{3}{|c|}{$\begin{array}{c}\text { 60-MW, 4-hour Duration, } \\
\text { 240-MWh }\end{array}$} & \multicolumn{3}{|c|}{$\begin{array}{l}\text { 60-MW, 2-hour Duration, } \\
\text { 120-MWh }\end{array}$} & \multicolumn{3}{|c|}{$\begin{array}{l}\text { 60-MW, 1-hour Duration, } \\
\text { 60-MWh }\end{array}$} & \multicolumn{3}{|c|}{$\begin{array}{c}\text { 60-MW, 0.5-hour Duration, } \\
\text { 30-MWh }\end{array}$} \\
\hline & $\begin{array}{l}\text { Total Cost } \\
\text { (\$) }\end{array}$ & $\$ / k W h$ & $\$ / \mathbf{W}$ & $\begin{array}{l}\text { Total Cost } \\
\text { (\$) }\end{array}$ & $\$ / k W h$ & $\$ / \mathbf{W}$ & $\begin{array}{l}\text { Total Cost } \\
\text { (\$) }\end{array}$ & $\$ / k W h$ & $\$ / \mathbf{W}$ & $\begin{array}{l}\text { Total Cost } \\
\text { (\$) }\end{array}$ & $\$ / k W h$ & $\$ / \mathbf{W}$ \\
\hline Battery central inverter & $3,600,000$ & 15 & 0.06 & $3,600,000$ & 30 & 0.06 & $3,600,000$ & 59 & 0.06 & $3,600,000$ & 119 & 0.06 \\
\hline Structural BOS & $3,173,302$ & 13 & 0.05 & $1,853,216$ & 15 & 0.03 & $1,193,174$ & 20 & 0.02 & 863,152 & 28 & 0.01 \\
\hline $\begin{array}{l}\text { Installation labor } \\
\text { \& equipment }\end{array}$ & $4,694,348$ & 19 & 0.08 & $3,706,099$ & 31 & 0.06 & $3,211,975$ & 53 & 0.05 & $2,964,913$ & 98 & 0.05 \\
\hline EPC overhead & $2,354,557$ & 10 & 0.04 & $1,623,195$ & 13 & 0.03 & $1,257,513$ & 21 & 0.02 & $1,074,673$ & 35 & 0.02 \\
\hline Sales tax & $3,807,403$ & 16 & 0.06 & $2,236,341$ & 18 & 0.04 & $1,509,970$ & 25 & 0.03 & $1,092,844$ & 36 & 0.02 \\
\hline$\sum E P C$ cost & $72,789,126$ & 300 & 1.21 & $42,866,336$ & 354 & 0.71 & $28,984,101$ & 478 & 0.48 & $21,059,043$ & 695 & 0.35 \\
\hline Contingency & $2,265,878$ & 9 & 0.04 & $1,359,264$ & 11 & 0.02 & 938,331 & 15 & 0.02 & 698,347 & 23 & 0.01 \\
\hline Developer overhead & $1,603,157$ & 7 & 0.03 & 961,708 & 8 & 0.02 & 663,889 & 11 & 0.01 & 494,095 & 16 & 0.01 \\
\hline EPC/developer profit & $3,940,146$ & 16 & 0.07 & $2,366,604$ & 20 & 0.04 & $1,636,554$ & 27 & 0.03 & $1,219,812$ & 40 & 0.02 \\
\hline$\sum$ Developer cost & $9,953,946$ & 41 & 0.17 & $6,832,340$ & 56 & 0.11 & $5,383,539$ & 89 & 0.09 & $4,557,019$ & 150 & 0.08 \\
\hline $\begin{array}{l}\sum \text { Total energy } \\
\text { storage system cost }\end{array}$ & $82,743,072$ & 341 & 1.38 & $49,698,676$ & 410 & 0.83 & $34,367,640$ & 567 & 0.57 & $25,616,062$ & 845 & 0.43 \\
\hline
\end{tabular}




\subsection{Utility-Scale PV-plus-Storage System Cost Model}

Here we combine our energy storage cost model with our PV system cost model in various configurations, including (1) colocated PV-plus-storage systems versus PV and storage systems located in different places and (2) DC-coupled versus AC-coupled battery configurations for the colocated PV-plus-storage systems. As shown in Table 19, colocation enables sharing of several hardware components by the PV and energy storage systems, which can reduce costs. Colocation can also reduce soft costs related to site preparation, land acquisition, installation labor, permitting, interconnection, and EPC/developer overhead and profit.

Table 19. Cost Factors for Siting PV and Storage Together versus Separately

\begin{tabular}{lll}
\hline Model Component & Colocated PV-plus-Storage & $\begin{array}{l}\text { PV-plus-Storage } \\
\text { at Different Sites }\end{array}$ \\
\hline Site preparation ${ }^{38}$ & Once & Twice \\
\hline Land acquisition cost & Lower & Higher \\
\hline $\begin{array}{l}\text { Hardware sharing between PV } \\
\text { and energy storage }\end{array}$ & $\begin{array}{l}\text { Yes (step-up transformer, switchgear, } \\
\text { monitor, and controls) }\end{array}$ & No \\
\hline Installation labor cost & $\begin{array}{l}\text { Lower (due to hardware sharing and } \\
\text { single labor mobilization) }\end{array}$ & Higher \\
\hline EPC/developer overhead and profit & $\begin{array}{l}\text { Lower (due to lower labor cost, BOS, } \\
\text { and total system cost) }\end{array}$ & Higher \\
\hline Interconnection and permitting & Once & Twice \\
\hline
\end{tabular}

When PV and battery storage are colocated, the subsystems can be connected by either a DCcoupled or an AC-coupled configuration (Figure 48). A DC-coupled system needs only one bidirectional inverter, connects battery storage directly to the PV array, and enables the battery to charge and discharge from the grid. On the other hand, an AC-coupled system needs both a PV inverter and a bidirectional inverter, and there are multiple conversion steps between DC and AC to charge or discharge the battery. Also, the transmission line could be used for both PV and battery storage systems.

The advantages of the DC-coupled system include the following:

1. A DC-coupled system uses only a single bidirectional inverter (Table 20), thus reducing costs for the inverter, inverter wiring, and inverter housing.

2. Because of the extra conversion between $\mathrm{DC}$ and $\mathrm{AC}$, an $\mathrm{AC}$-coupled system may have lower roundtrip efficiency for battery charging than a DC-coupled system, which charges the battery directly. However, as power electronics are becoming more efficient, the actual efficiency difference is becoming smaller (Enphase 2019).

3. Because the battery is connected directly to the PV array, excess PV generation that would otherwise be clipped by an AC-coupled system at the inverter level can be sent directly to the battery, which could improve system economics (DiOrio and Hobbs 2018).

\footnotetext{
${ }^{38}$ Site preparation is a subcategory of labor cost, so it is not shown in the cost breakdown chart.
} 

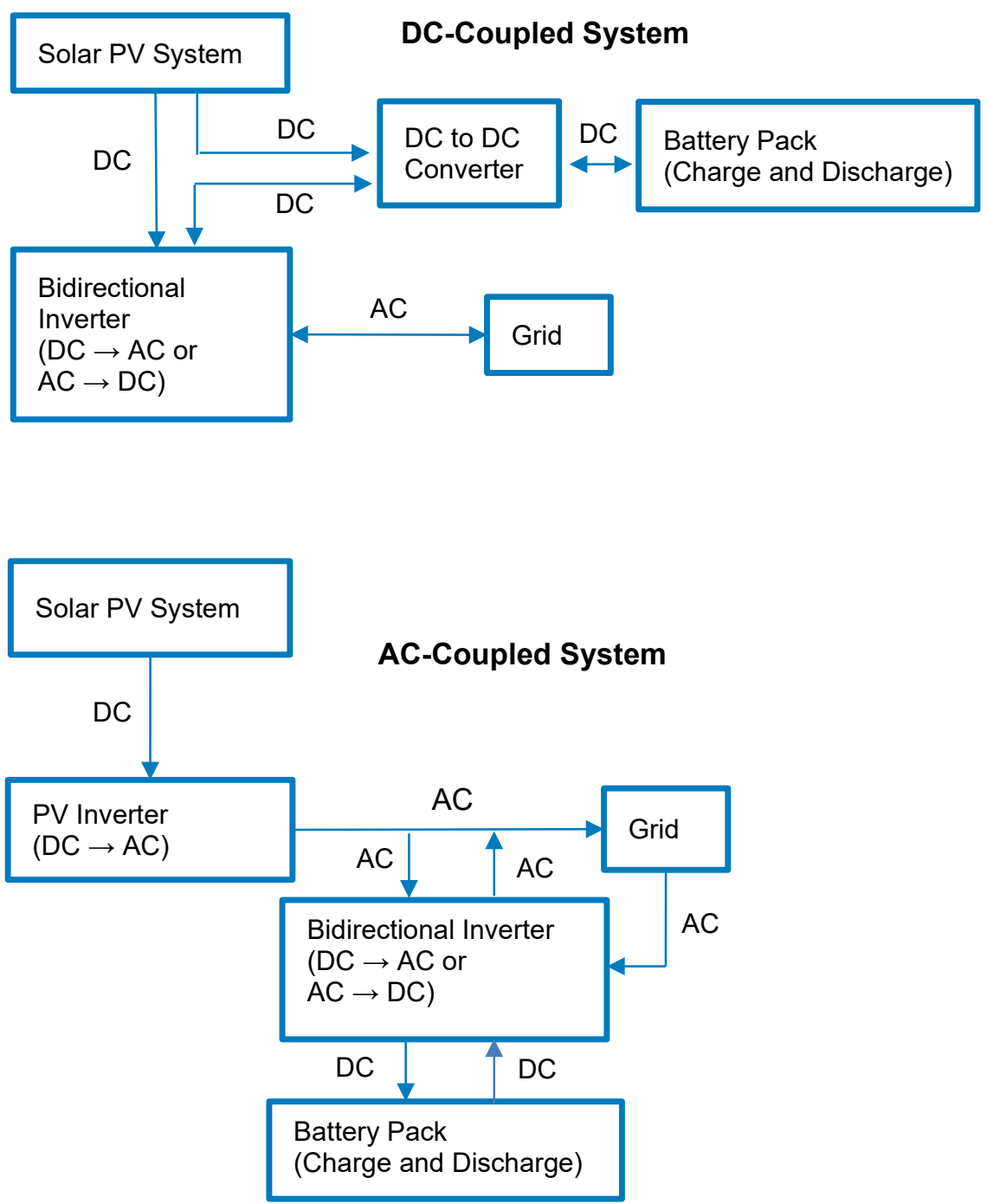

Figure 48. DC-coupled and AC-coupled PV-plus-storage system configurations 
Table 20. Comparison of DC- and AC-Coupling for Utility-Scale PV-plus-Storage Systems

\begin{tabular}{|c|c|c|}
\hline Model Component & DC-Coupled Configuration & AC-Coupled Configuration \\
\hline Number of inverters & 1 (bidirectional inverter for battery) & $\begin{array}{l}2 \text { (bidirectional inverter for battery } \\
\text { plus grid-tied inverter for PV), } \\
\text { resulting in higher costs for the } \\
\text { inverter, inverter wiring, and } \\
\text { inverter housing }\end{array}$ \\
\hline Battery rack size & $\begin{array}{l}\text { Smaller (because battery is directly } \\
\text { connected to PV), }{ }^{a} \text { resulting in more } \\
\text { HVAC and fire-suppression systems } \\
\text { required }\end{array}$ & Larger \\
\hline Structural BOS & $\begin{array}{l}\text { More (due to smaller battery } \\
\text { rack size) }\end{array}$ & Less \\
\hline Electrical BOS & $\begin{array}{l}\text { Less (but needs additional DC-to-DC } \\
\text { converters) }\end{array}$ & $\begin{array}{l}\text { More (due to additional wiring } \\
\text { for inverters) }\end{array}$ \\
\hline Installation labor cost & $\begin{array}{l}\text { More (due to smaller battery rack size } \\
\text { and more skilled labor and labor } \\
\text { hours required for DC work) }\end{array}$ & Less \\
\hline EPC overhead & $\begin{array}{l}\text { More (due to higher installation } \\
\text { labor cost) }\end{array}$ & Less \\
\hline Sales tax & Less & $\begin{array}{l}\text { More (due to higher total } \\
\text { hardware costs) }\end{array}$ \\
\hline EPC/developer profit & Less & $\begin{array}{l}\text { More (due to higher total EPC and } \\
\text { developer costs) }\end{array}$ \\
\hline
\end{tabular}

a Because a PV system is not directly connected to a battery in an AC-coupled configuration, the battery racks are fewer and larger; this configuration is less costly than a DC-coupled system in which multiple distributed battery racks are deployed and managed. For example, using five smaller battery racks rather than one large rack requires five fire-suppression systems and five air conditioning systems.

The advantages of the AC-coupled system include the following:

1. Because the battery racks are not directly connected to the PV system in AC-coupled systems, these systems can use larger battery racks and thus reduce the number of HVAC and fire-suppression systems in the containers. This feature also reduces installation labor costs compared with DC-coupled systems.

2. For a retrofit (i.e., adding battery storage to an existing PV array), an AC-coupled battery may be more practical than a DC-coupled battery, because DC-coupled systems require installers to replace the existing PV inverter with a bidirectional inverter. Thus, the additional costs that are due to replacing the inverter and rewiring the system could make retrofit costs higher for a DC-coupled system than for an AC-coupled system (Ardani et al. 2017). In addition, AC-coupled systems enable the option of upgrading the PV and battery separately, because these systems are independent of one another. 
3. Because AC-coupled systems have separate PV and battery systems, installers have more flexibility to adjust the battery location. For instance, DC-coupled systems require batteries to be installed next to the bidirectional inverter, and the resulting need for maintenance crews to enter the PV field can make maintenance more time consuming. Because AC-coupled systems can have batteries located outside the PV field, maintenance work can be quicker and easier.

\subsection{Utility-Scale Model Output}

Figure 49 (page 81) summarizes our model results for several system types and configurations:

- Standalone 100-MW PV system with one-axis tracking ( $\$ 101$ million)

- Standalone 60-MW/240-MWh, 4-hour-duration energy storage system (\$83 million)

- Colocated DC-coupled PV (100-MW) plus storage (60-MW/240-MWh, 4-hour-duration) system (\$173 million)

- Colocated AC-coupled PV (100-MW) plus storage (60-MW/240-MWh, 4-hour-duration) system (\$171 million)

- PV (100-MW) plus storage (60-MW/240-MWh, 4-hour-duration) system with PV and storage components sited in different locations ( $\$ 183$ million).

Table 21 shows detailed costs for the three PV-plus-storage configurations. Colocating the PV and storage subsystems produces cost savings by reducing costs related to site preparation, land acquisition, permitting, interconnection, installation labor, hardware (via sharing of hardware such as switchgears, transformers, and controls), overhead, and profit. The cost of the colocated AC-coupled system is $7 \%$ lower than the cost of the system with PV and storage sited separately.

Using DC-coupling rather than AC-coupling results in a $1 \%$ higher total cost, which is the net result of cost differences between DC-coupling and AC-coupling in the categories of solar inverter, structural BOS, electrical BOS, labor, EPC and developer overhead, sales tax, contingency, and profit. For an actual project, however, cost savings may not be the only factor in choosing DC- or AC-coupling. Additional factors - such as retrofit considerations, system performance (including energy loss due to clipping), design flexibility, and O\&M—should be considered. 


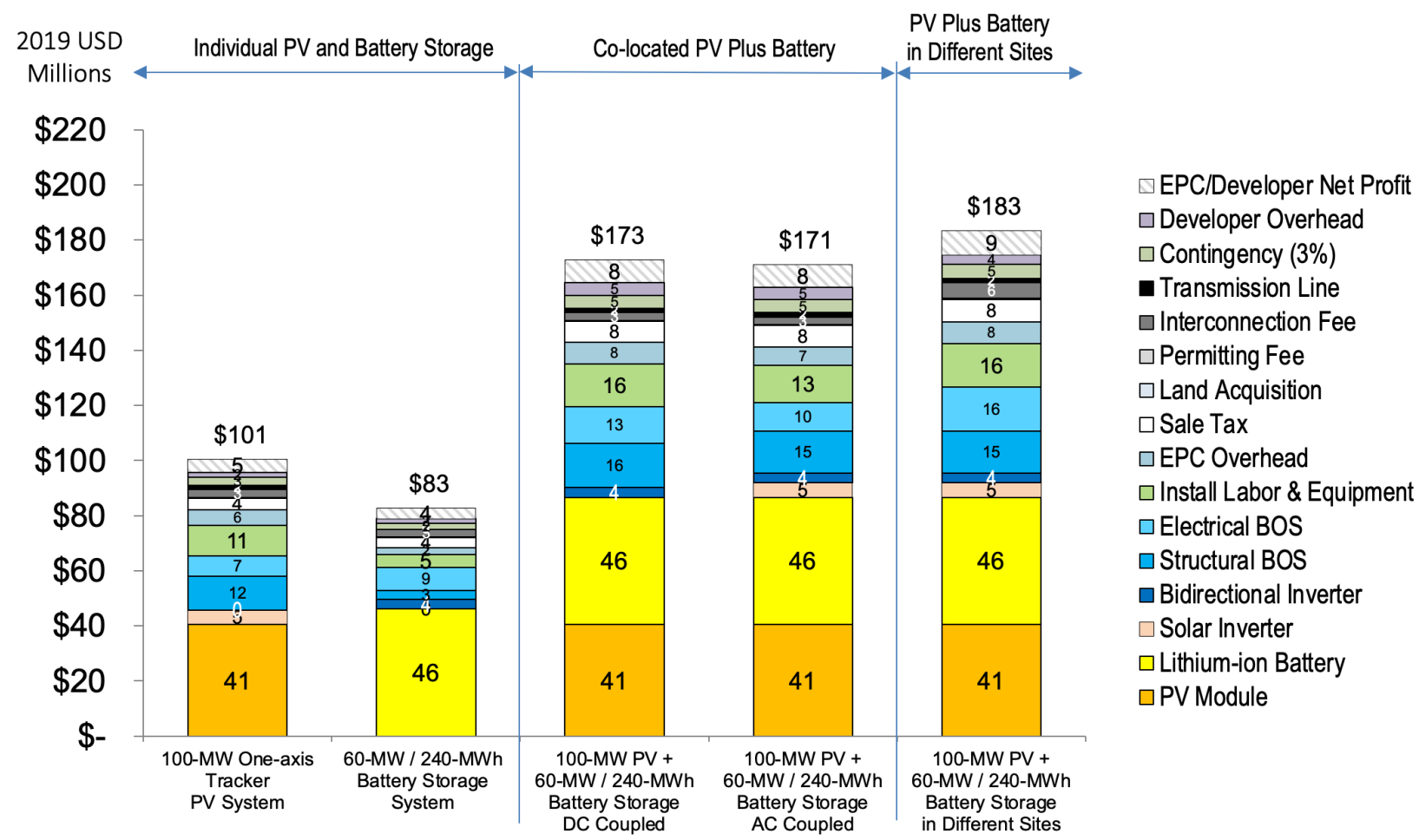

Figure 49. Cost benchmarks for PV-plus-storage systems (4-hour duration) in different sites and the same site (DC-coupled and AC-coupled cases), Q1 2020 
Table 21. Detailed Cost Breakdown for Utility-Scale Li-ion PV-plus-Storage Systems

\begin{tabular}{|c|c|c|c|}
\hline \multirow[b]{2}{*}{ Model Component } & \multicolumn{3}{|c|}{ Total Cost } \\
\hline & $\begin{array}{l}\text { 100-MW PV Plus } \\
60-M W / 240-M W h \\
\text { Battery, DC- } \\
\text { Coupled, Colocated }\end{array}$ & $\begin{array}{l}\text { 100-MW PV Plus } \\
60-M W / 240-M W h \\
\text { Battery, AC- } \\
\text { Coupled, Colocated }\end{array}$ & $\begin{array}{l}\text { 100-MW PV Plus } \\
60-M W / 240-M W h \\
\text { Battery, in } \\
\text { Different Sites }\end{array}$ \\
\hline PV module & $\$ 40,587,666$ & $\$ 40,587,666$ & $\$ 40,587,666$ \\
\hline Li-ion battery & $\$ 46,091,749$ & $\$ 46,091,749$ & $\$ 46,091,749$ \\
\hline Solar inverter & - & $\$ 5,171,344$ & $\$ 5,171,344$ \\
\hline Bidirectional inverter & $\$ 3,563,795$ & $\$ 3,563,795$ & $\$ 3,563,795$ \\
\hline Structural BOS & $\$ 15,908,348$ & $\$ 15,289,203$ & $\$ 15,342,164$ \\
\hline Electrical BOS & $\$ 13,384,607$ & $\$ 10,336,576$ & $\$ 15,855,408$ \\
\hline Installation labor \& equipment & $\$ 15,537,385.79$ & $\$ 13,417,123.80$ & $\$ 15,757,821$ \\
\hline EPC overhead & $\$ 7,905,594$ & $\$ 6,826,782$ & $\$ 8,017,754$ \\
\hline Sales tax & $\$ 7,645,117$ & $\$ 7,741,319$ & $\$ 8,097,671$ \\
\hline$\sum E P C$ cost & $\$ 150,624,262$ & $\$ 149,025,558$ & $\$ 158,485,372$ \\
\hline Permitting fee & $\$ 198,395$ & $\$ 198,395$ & $\$ 396,790$ \\
\hline Interconnection fee & $\$ 2,784,560$ & $\$ 2,784,560$ & $\$ 5,569,120$ \\
\hline Transmission line & $\$ 1,669,331$ & $\$ 1,669,331$ & $\$ 1,669,331$ \\
\hline Contingency & $\$ 4,658,296$ & $\$ 4,610,335$ & $\$ 4,980,515$ \\
\hline Developer overhead & $\$ 4,658,296$ & $\$ 4,610,335$ & $\$ 3,523,821$ \\
\hline EPC/developer profit & $\$ 8,229,657$ & $\$ 8,144,926$ & $\$ 8,688,259$ \\
\hline$\sum$ Developer cost & $\$ 22,198,536$ & $\$ 22,017,883$ & $\$ 24,827,837$ \\
\hline$\sum$ Total system cost & $\$ 172,822,798$ & $\$ 171,043,440$ & $\$ 183,313,209$ \\
\hline
\end{tabular}

\subsection{Utility-Scale PV-plus-Storage Price Benchmark Historical Trends}

Figure 50 shows 9\% and 8\% reductions in utility-scale PV-plus-storage benchmarks between 2018 (Fu, Remo, and Margolis 2018) and 2020 (this report), for DC-coupled and AC-coupled systems. For the DC-coupled system, approximately $28 \%$ of that reduction can be attributed to the Li-ion battery plus bidirectional inverter, while electrical and structural BOS decreased system cost by $13 \%$; an additional $17 \%$ can be attributed to lower labor costs, and the final $42 \%$ is attributable to other soft costs, including PII, sales tax, overhead, and net profit. For the ACcoupled system, approximately $30 \%$ of the reduction can be attributed to the Li-ion battery plus bidirectional inverter, and 4\% to electrical and structural BOS; an additional $16 \%$ can be attributed to lower labor costs, and the final $49 \%$ is attributable to other soft costs, including PII, sales tax, overhead, and net profit. 


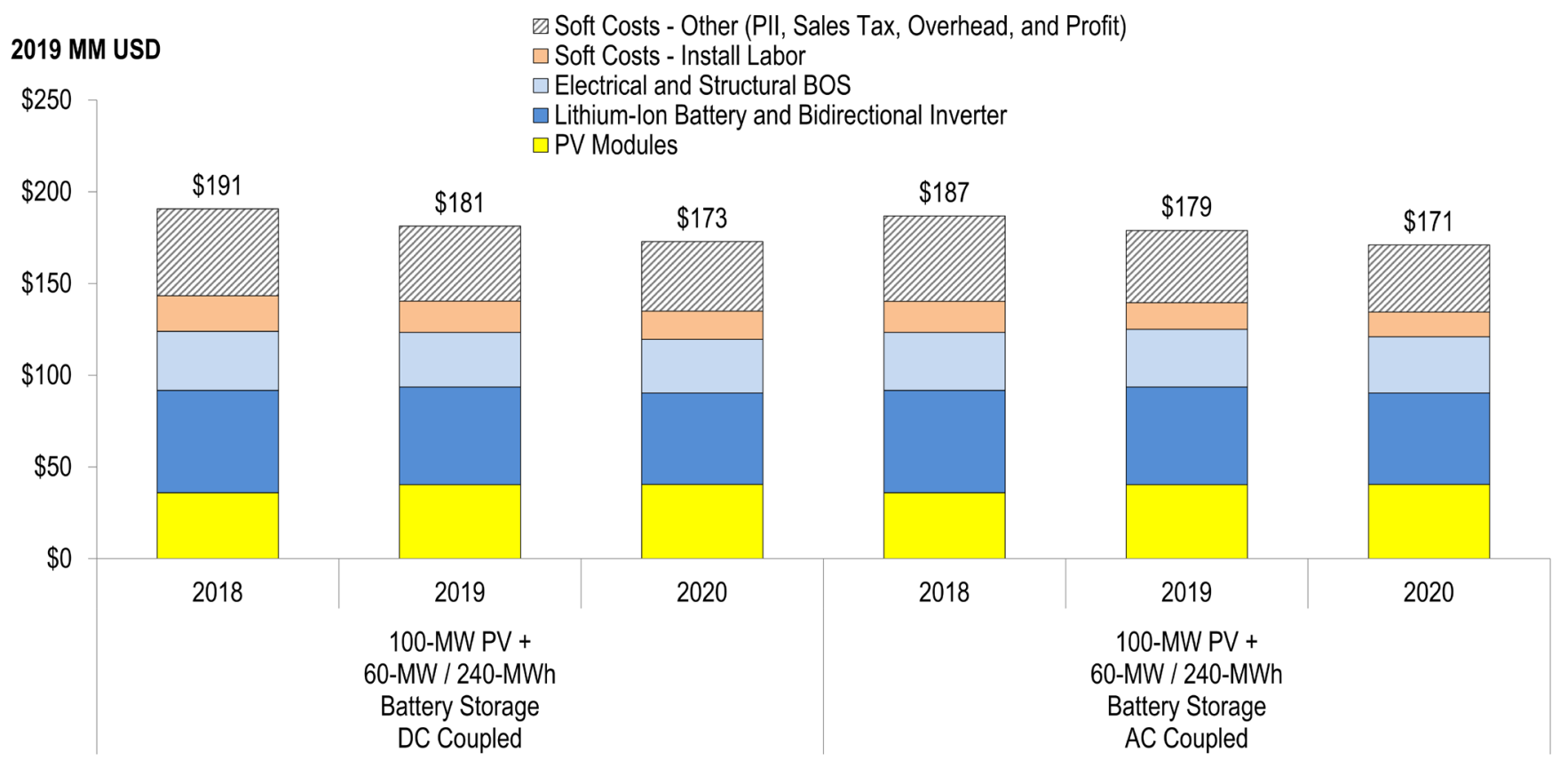

Figure 50. Utility-scale PV-plus-storage system cost benchmark summary 2018-2020, DC-coupled and AC-coupled

$\mathrm{MM}=$ million

\subsection{Utility-Scale Levelized Cost of Solar-plus-Storage}

For this year's benchmark report, we calculate the LCOSS for utility-scale PV-plus-storage, with the same formula and caveats as we use for our residential and commercial PV-plus-storage systems (see Section 6.5). BNEF (2019c) and Lazard (2018) have performed similar LCOSS calculations. None of these LCOSS calculations, including the ones in this report, attempts to value the electricity generated by these systems or the different ways they may operate. Storage value calculations require integrating storage dispatch into regional capacity expansion, load, or reliability models. For a detailed discussion of storage value, see Balducci et al. (2018), Denholm et al. (2019), Frew et al. (2018), and Schmidt et al. (2019). Similar to LCOE, LCOSS does not focus on value but rather can help track improvements to all costs of a utility-scale PV-plusstorage system over time (as opposed to just upfront costs), and the metric can provide limited comparisons with other dispatchable electricity generation technologies (e.g., natural gas). Table 22 lists our model inputs and assumptions for calculating utility-scale LCOSS. 
Table 22. Utility-Scale LCOSS Inputs and Assumptions

\begin{tabular}{|c|c|c|}
\hline Model Component & Model Input & Description \\
\hline System size & $\begin{array}{l}\text { 100-MW PV plus 60-MW / } 240- \\
\text { MWh battery storage, AC- } \\
\text { coupled }\end{array}$ & \\
\hline Initial investment & $\$ 171$ million & $\begin{array}{l}2019 \text { utility-scale PV-plus-storage } \\
\text { benchmark, AC-coupled }\end{array}$ \\
\hline $\begin{array}{l}\text { First follow-on } \\
\text { investments (inverter, } \\
\text { battery replacements) }\end{array}$ & $\$ 7.4$ million in year 10 & $\begin{array}{l}20 \% \text { of batteries replaced after } 10 \text { years } \\
\text { due to battery capacity dropping } 20 \% \text {. We } \\
\text { assume costs for battery and bidirectional } \\
\text { inverters drop } 20 \% \text { in the next } 10 \text { years. }\end{array}$ \\
\hline $\begin{array}{l}\text { Second follow-on } \\
\text { investments (inverter, } \\
\text { battery replacements) }\end{array}$ & $\$ 5.5$ million in year 20 & $\begin{array}{l}20 \% \text { of batteries replaced after } 20 \text { years } \\
\text { due to battery capacity dropping } 20 \% \text {. We } \\
\text { assume costs for battery and bidirectional } \\
\text { inverters drop } 40 \% \text { in the next } 20 \text { years. }\end{array}$ \\
\hline Real discount rate & $2.7 \%$ & Consistent with LCOE formula \\
\hline Tax rate & $25.7 \%$ & $21 \%$ federal, $6 \%$ state \\
\hline Residual value & $\$ 0$ & \\
\hline $\begin{array}{l}\text { Initial annual } \\
\text { system production }\end{array}$ & $\begin{array}{l}\text { High resource area: } 2,185 \\
\text { MWh/MW } \\
\text { Medium resource area: } 1,707 \\
\text { MWh/MW } \\
\text { Low resource area: } 1,572 \\
\text { MWh/MW }\end{array}$ & \\
\hline $\begin{array}{l}\text { Percentage of } \\
\text { generated solar } \\
\text { electricity fed to } \\
\text { battery }\end{array}$ & $\begin{array}{l}\text { High resource area: } 30 \% \\
\text { Medium resource area: } 39 \% \\
\text { Low resource area: } 42 \%\end{array}$ & $\begin{array}{l}\text { Assumes a } 75 \% \text { discharge per day for a } 4 \\
\text { hour, } 60-\mathrm{MW} \text { battery }\end{array}$ \\
\hline $\begin{array}{l}\text { Roundtrip energy } \\
\text { losses from } \\
\text { PV/battery/grid }\end{array}$ & $10 \%$ & \\
\hline $\begin{array}{l}\text { Roundtrip energy } \\
\text { losses from } \\
\text { grid/battery/grid }\end{array}$ & $8 \%$ & \\
\hline Charging cost & $\$ 0$ & $\begin{array}{l}\text { Battery is charged solely by PV due to } \\
\text { ITC considerations }\end{array}$ \\
\hline O\&M (\$/kW/yr) & $\$ 27$ & $\begin{array}{l}\text { Assumes storage O\&M adds } \$ 10 / \mathrm{kW}-\mathrm{yr} \\
\text { to } \mathrm{PV} \text { costs }\end{array}$ \\
\hline PV Degradation & $0.70 \%$ & \\
\hline $\begin{array}{l}\text { Annual electricity } \\
\text { purchased from grid }\end{array}$ & 0 & \\
\hline System lifetime & 30 years & \\
\hline Inflation & $2.5 \%$ & \\
\hline
\end{tabular}


We use these inputs to calculate LCOSS via Equation 1. Figure 51 shows the resulting LCOSS for a colocated AC-coupled PV (100 MW) plus storage (60 MW/240 MWh, 4-hour duration) system, as well as the LCOE of a 100-MW PV-standalone system, with one-axis tracking. LCOSS is calculated to be $\$ 83 / \mathrm{MWh}$ without the federal ITC and $\$ 57 / \mathrm{MWh}$ with the $30 \%$ ITC, with a medium resource for PV electricity production. ${ }^{39}$ Based on these calculations, PV-plusstorage LCOSS is $\$ 40 / \mathrm{MWh}$ higher than standalone-PV LCOE without the ITC, and $\$ 28 / \mathrm{MWh}$ higher with a 30\% ITC. Bolinger, Seel, and Robson (2019) reported a storage premium of $\$ 10$ $\$ 15 / \mathrm{MWh}$ for PPAs with a 30\% ITC, for systems that have a 4-hour battery sized to $50 \%-75 \%$ of the PV capacity.

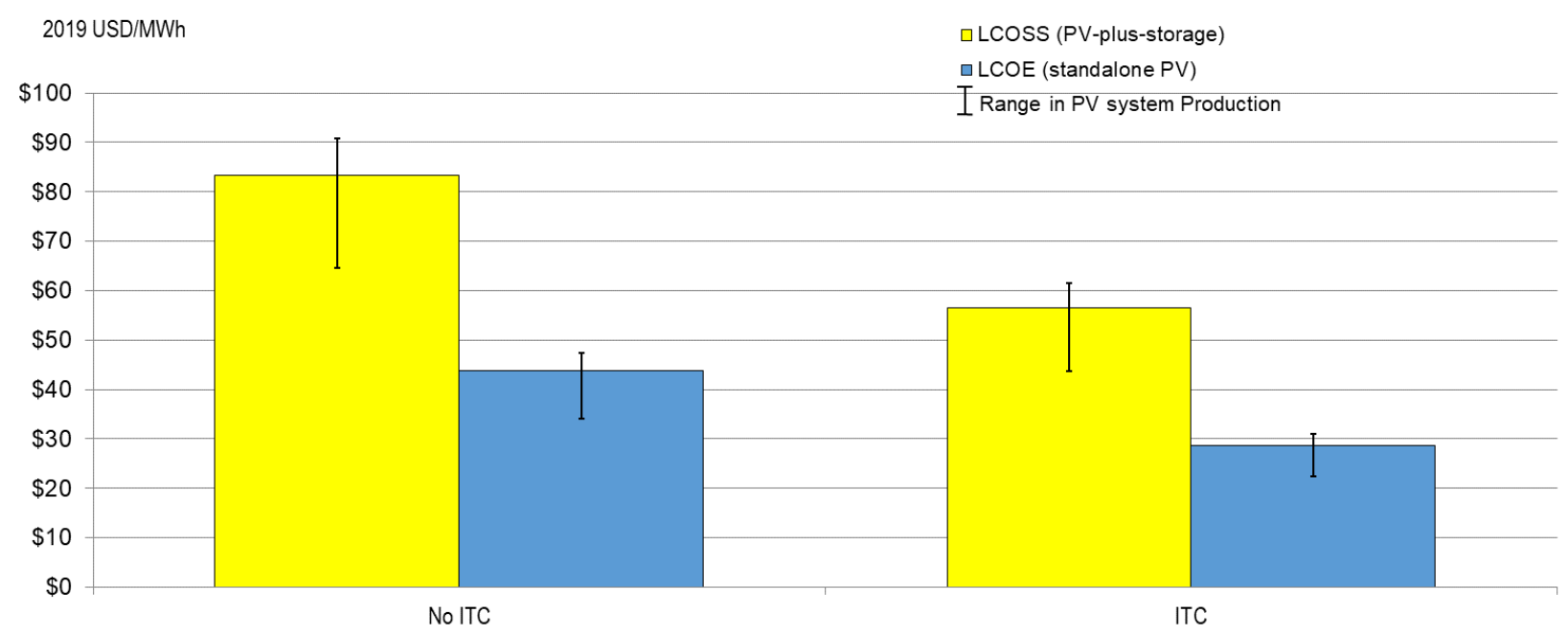

Figure 51. U.S. utility-scale LCOSS for an AC-coupled PV (100 MW) plus storage (60 MW/240 MWh, 4-hour duration) system and LCOE for a 100-MW PV standalone system, Q1 2020

LCOSS is calculated for each scenario with a medium CF (representing Kansas City); LCOSS and LCOE ranges based on high and low CF assumptions; all other values remain the same.

\footnotetext{
${ }^{39} \mathrm{We}$ do not change the inputs and assumptions between the ITC and non-ITC cases, despite the fact that the inputs in the LCOSS calculation assume the owner of the PV-plus-storage system is operating the plant such that they can claim the ITC on the storage equipment. In reality, an owner would likely operate a PV-plus-storage system differently without the ITC. Additionally, we assume projects can qualify as starting construction before 2020, allowing them to claim a 30\% ITC, instead of the $26 \%$ ITC for projects starting construction in 2020.
} 


\section{Conclusions}

NREL's bottom-up cost models can be used to assess the costs of PV and storage systems using various configurations. They can also estimate future potential cost-reduction opportunities for PV and PV-plus-storage systems, thus helping guide research and development aimed at advancing cost-effective system configurations. The data in this annual benchmark report inform the formulation of and track progress toward SETO's GPRA cost targets.

Based on our bottom-up modeling, the Q1 2020 cost benchmarks are:

- $\$ 2.71 / \mathrm{W}_{\mathrm{DC}}\left(\right.$ or $\left.\$ 3.12 / \mathrm{W}_{\mathrm{AC}}\right)$ for residential PV systems

- $\$ 1.72 / \mathrm{W}_{\mathrm{DC}}$ (or $\$ 1.96 / \mathrm{W}_{\mathrm{AC}}$ ) for commercial rooftop PV systems

- $\$ 1.72 / \mathrm{W}_{\mathrm{DC}}$ (or $\$ 1.91 / \mathrm{W}_{\mathrm{AC}}$ ) for commercial ground-mount PV systems

- $\$ 0.94 / \mathrm{W}_{\mathrm{DC}}\left(\right.$ or $\$ 1.28 / \mathrm{W}_{\mathrm{AC}}$ ) for fixed-tilt utility-scale PV systems

- $\$ 1.01 / \mathrm{W}_{\mathrm{DC}}\left(\right.$ or $\$ 1.35 / \mathrm{W}_{\mathrm{AC}}$ ) for one-axis-tracking utility-scale PV systems ${ }^{40}$

- $\$ 26,153-\$ 28,371$ for a $7-\mathrm{kW}$ residential PV system with $3 \mathrm{~kW} / 6 \mathrm{kWh}$ of storage and $\$ 35,591-\$ 37,909$ for a $7-\mathrm{kW}$ residential PV system with $5 \mathrm{~kW} / 20 \mathrm{kWh}$ of storage

- \$2.07 million-\$2.13 million for a 1-MW commercial ground-mount PV system colocated with $600 \mathrm{~kW} / 2.4 \mathrm{MWh}$ of storage

- \$171 million-\$173 million for a 100-MW PV system colocated with $60 \mathrm{MW} / 240 \mathrm{MWh}$ of storage.

Overall, modeled installed costs of PV and storage systems continued to decline between Q1 2019 and Q1 2020. Figure 52 puts our Q1 2020 benchmark results in context with the results of previous NREL benchmarking analyses. When comparing the results across this period, note that:

1. Values are inflation-adjusted using the CPI (2019). Thus, historical values from our models are adjusted and presented as real USD instead of nominal USD.

2. Cost categories are aggregated for comparison purposes. "Soft Costs - Others" represents:
A. PII
B. Transmission line (if any)
C. Sales tax
D. EPC/developer overhead and profit.

3. The current versions of our cost models make a few significant changes from the versions used in our Q1 2018 benchmark report (Fu, Feldman, and Margolis 2018). To better distinguish the historical cost trends over time from the changes to our cost models, we also calculate Q1 2019 and Q1 2020 PV benchmarks using the Q1 2018 versions of the residential, commercial, and utility-scale PV models. Appendix A provides a detailed discussion of the changes made to the models between previous versions (Fu, Feldman, and Margolis 2018) and this year's versions.

\footnotetext{
${ }^{40}$ The dollar-per-watt total cost value is benchmarked as three significant figures, because the model inputs, such as module and inverter prices, use three significant figures.
} 
4. Our Q1 2019 and Q1 2020 benchmarks use monocrystalline PV modules, whereas all historical benchmarks used multicrystalline PV modules. This switch reflects the overall trend occurring in the U.S. market.

5. For previous editions of this report, we assumed a land acquisition cost of $\$ 0.03 / \mathrm{W}$. Based on Wiser et al. (2020), which stated that most utility-scale PV projects do not own the land on which the PV system is placed, we have reclassified land costs from an upfront capital expenditure (land acquisition) to an operating expenditure (lease payments) for 2019 and 2020.

From 2010 to 2020 , there was a $64 \%, 69 \%$, and $82 \%$ reduction in the residential, commercial rooftop, and utility-scale (one-axis) PV system cost benchmark, respectively (Figure 52). The inflation-adjusted system cost differences between Q1 2019 and Q1 2020 are a \$0.06/W DC reduction for residential $\mathrm{PV}$, a $\$ 0.04 / \mathrm{W}_{\mathrm{DC}}$ reduction for commercial rooftop $\mathrm{PV}$, and a $\$ 0.01 / \mathrm{W}_{\text {DC }}$ reduction for utility-scale PV. Table 23 (page 89) shows the benchmarked values for all three sectors and drivers of cost decreases and increases.

BOS hardware cost reductions in Q1 2020 were counterbalanced by higher module costs, and soft costs remained relatively unchanged, year over year (Figure 18, Figure 26, Figure 33); this resulted in a steady percentage of soft costs as a percentage of total costs (Figure 53). ${ }^{41}$ The historical increase in soft cost proportion for residential and commercial PV systems in Figure 53 indicates soft costs declined more slowly than did hardware costs over time; it does not indicate soft costs increased on an absolute basis.

Soft costs and hardware costs interact with each other. For instance, module efficiency improvements have reduced the number of modules required to construct a system of a given size, thus reducing hardware costs. This trend has also reduced soft costs from direct labor and related installation overhead.

Also, our bottom-up system cost models enable us to investigate regional variations, system configurations (e.g., MLPE versus non-MLPE, fixed-tilt versus one-axis tracker, and small versus large system size). In addition, we consider business structures (e.g., small installer versus national integrator, and EPC versus developer). Different scenarios result in different costs, so consistent comparisons can only be made when cost scenarios are aligned.

${ }^{41}$ Soft cost $=$ total cost - hardware (module, inverter, structural and electrical BOS) cost. 
$\$ 9$

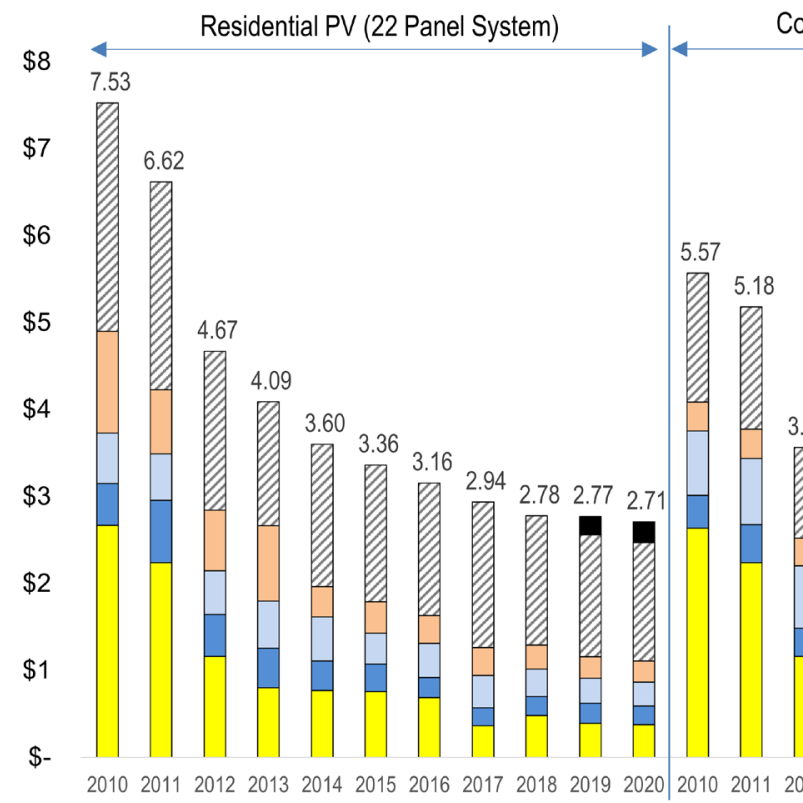

Commercial Rooftop PV (200 kW)

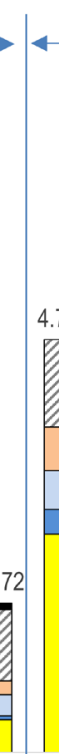

Utility-Scale PV,

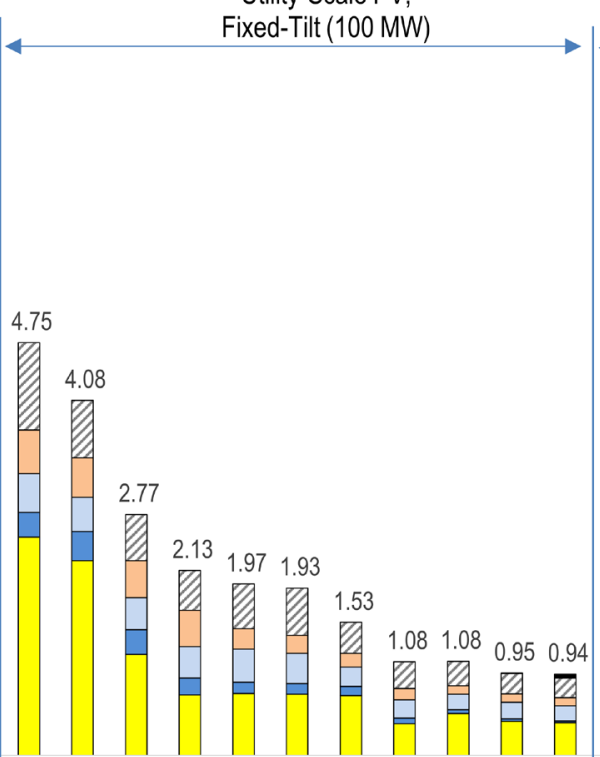

Utility-Scale PV, One-Axis Tracker (100 MW)

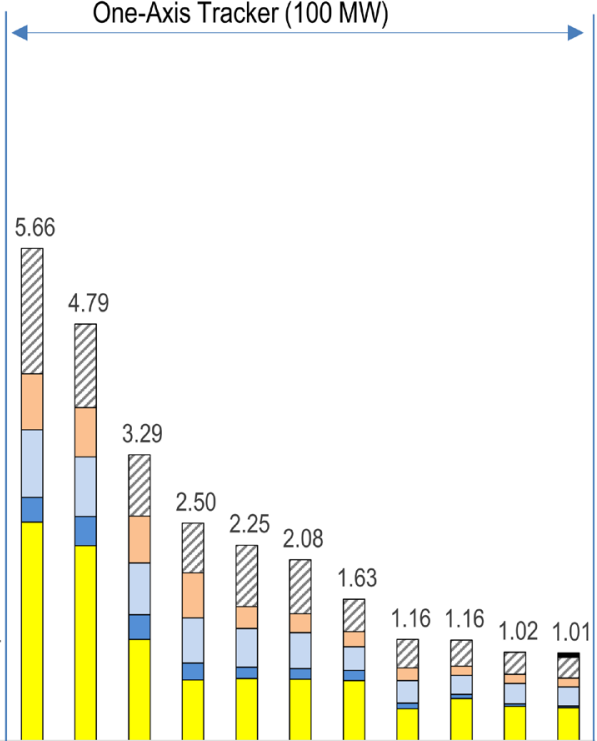

- Additional Costs from Model Updates*

Soft Costs - Others (PII, Land Acquisition, Transmission Line, Sales Tax, Overhead, and Profit)

$\square$ Soft Costs - Install Labor

$\square$ Hardware BOS - Structural and Electrical Components

$\square$ Inverter

$\square$ Module

\section{Figure 52. NREL PV system cost benchmark summary (inflation-adjusted), 2010-2020}

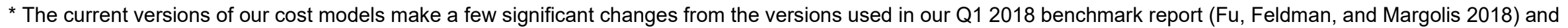

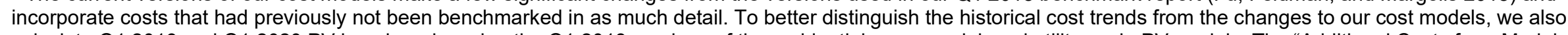

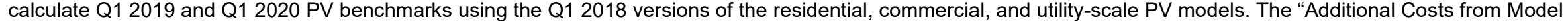
Updates" category represents the difference between modeled results. Using the previous costs models, the Q1 2019 and Q1 2020 benchmarks are calculated to be: Q1 $2019=\$ 2.56 / W_{D C}$ and Q1 $2020=\$ 2.47 / W_{D C}$ (residential PV); Q1 $2019=\$ 1.71 / W_{D C}$ and Q1 $2020=\$ 1.64 / W_{D C}\left(\right.$ commercial PV); Q1 2019= $\$ 0.94 / W_{D C}$ and Q1 2020 =

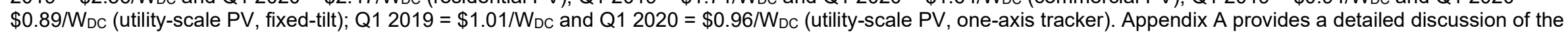
changes made to the models between last year's versions (Fu, Feldman, and Margolis 2018) and this year's versions. 
Table 23. Comparison of Q1 2019 and Q1 2020 PV System Cost Benchmarks

\begin{tabular}{|c|c|c|c|}
\hline Sector & Residential PV & $\begin{array}{l}\text { Commercial Rooftop } \\
\text { PV }\end{array}$ & $\begin{array}{l}\text { Utility-Scale PV, } \\
\text { One-Axis Tracking }\end{array}$ \\
\hline $\begin{array}{l}\text { Q1 } 2019 \\
\text { benchmarks in } \\
2019 \text { USD/WDC }\end{array}$ & $\$ 2.77$ & $\$ 1.76$ & $\$ 1.02$ \\
\hline $\begin{array}{l}\text { Q1 } 2020 \\
\text { Benchmarks in } \\
2019 \text { USD/WDC }\end{array}$ & $\$ 2.71$ & $\$ 1.72$ & $\$ 1.01$ \\
\hline $\begin{array}{l}\text { Drivers of cost } \\
\text { decrease }\end{array}$ & $\begin{array}{l}\text { - Higher module } \\
\text { efficiency (from } \\
19.2 \% \text { to } 19.5 \% \text { ) } \\
\text { - Decrease in BOS } \\
\text { hardware and supply } \\
\text { chain costs }\end{array}$ & $\begin{array}{l}\text { - Higher module } \\
\text { efficiency } \\
\text { - Lower material \& } \\
\text { equipment costs in } \\
\text { some categories }\end{array}$ & $\begin{array}{l}\text { - Higher module } \\
\text { efficiency } \\
\text { - Lower material \& } \\
\text { equipment costs in } \\
\text { some categories } \\
\text { - Movement of land } \\
\text { acquisition cost from } \\
\text { upfront capital } \\
\text { expenditures into } \\
\text { O\&M }\end{array}$ \\
\hline $\begin{array}{l}\text { Drivers of cost } \\
\text { increase }\end{array}$ & $\begin{array}{l}\text { - Higher labor wages } \\
\text { - Higher module costs }\end{array}$ & $\begin{array}{l}\text { - Higher labor wages } \\
\text { - Higher module costs }\end{array}$ & $\begin{array}{l}\text { - Higher labor wages } \\
\text { - Higher steel prices } \\
\text { - Higher module and } \\
\text { inverter costs }\end{array}$ \\
\hline
\end{tabular}

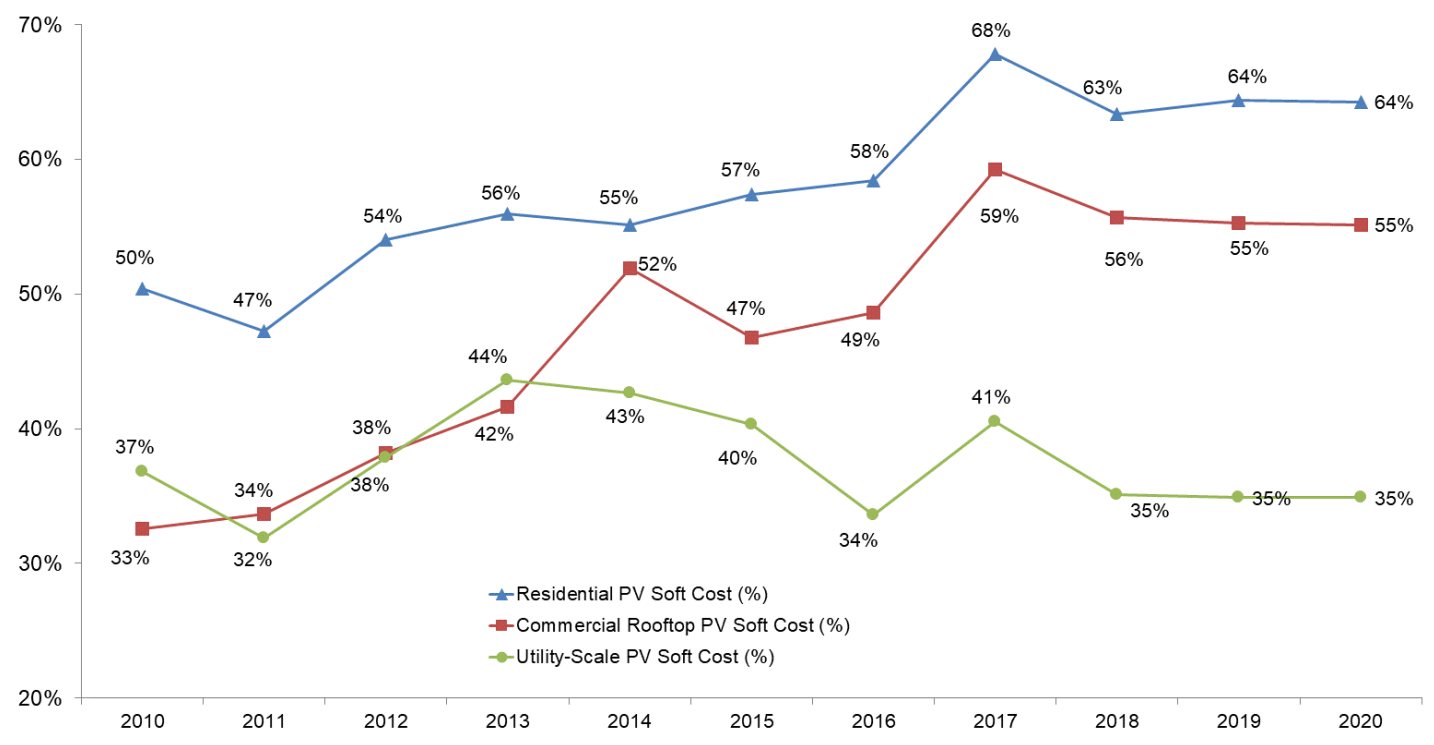

Figure 53. Modeled trend of soft cost as a proportion of total cost by sector, 2010-2020 
Finally, the reduction in installed cost - along with improvements in operation, system design, and technology - have resulted in significant LCOE reductions (Figure 54). Compared with system prices when SETO's LCOE targets were announced in 2010, U.S. residential and commercial rooftop PV systems are $93 \%$ and $97 \%$ toward achieving the 2020 targets, respectively, and U.S. utility-scale PV systems achieved their 2020 SETO target three years early. In recognition of both the transformative PV progress to date and the potential for additional innovation, SETO extended its goals in 2016 to reduce the unsubsidized LCOE by 2030 to $3 \notin / \mathrm{kWh}$ (utility-scale PV), $4 \notin / \mathrm{kWh}$ (commercial PV), and 5ф/kWh (residential PV). Continued research and development, public and private partnerships, and business innovations are necessary to achieve SETO's 2030 LCOE targets.

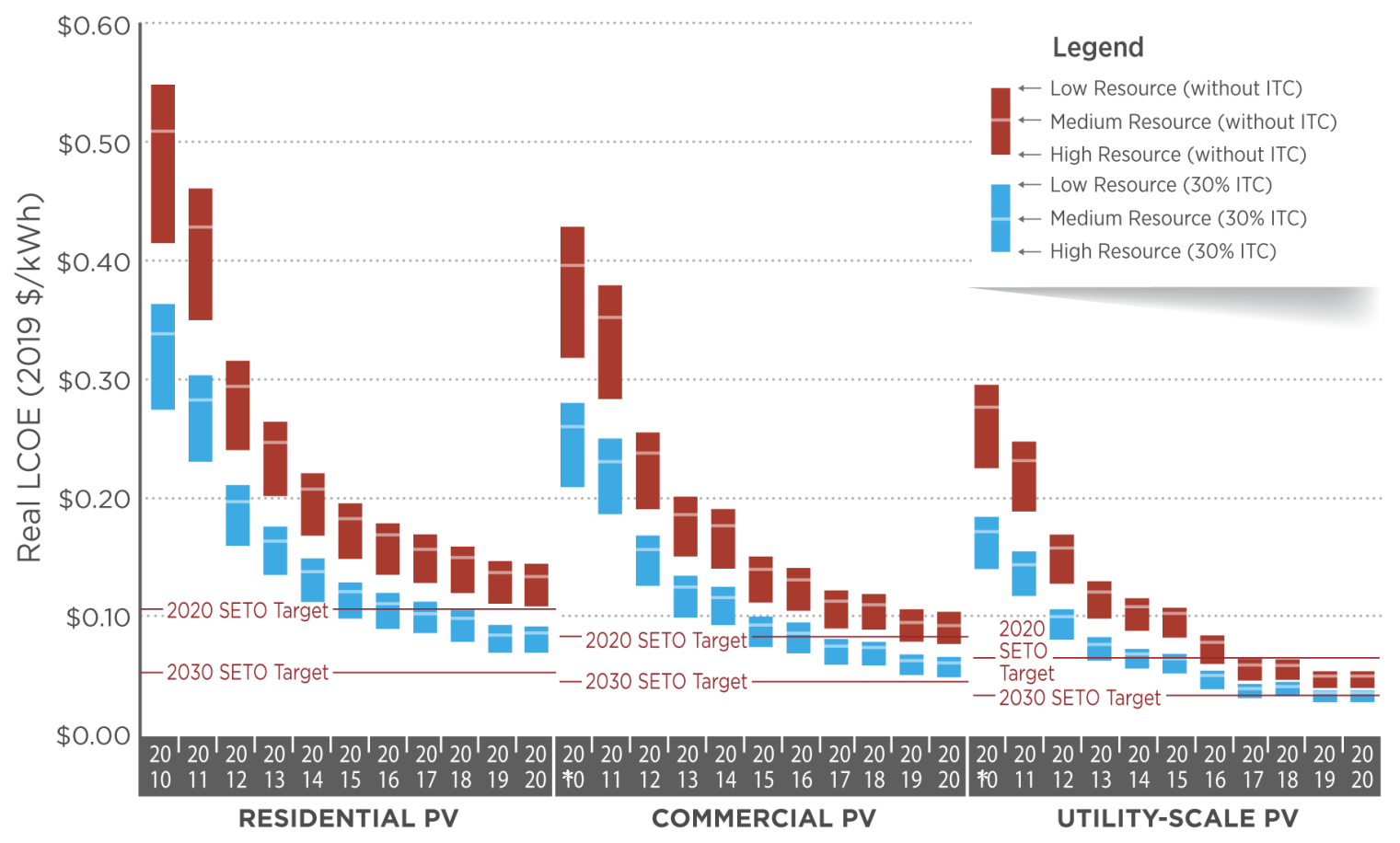

Figure 54. NREL PV LCOE benchmark summary (inflation-adjusted), 2010-2020

LCOE is calculated for each scenario under a low CF (New York City), medium CF (Kansas City), and high CF (Phoenix), but all other values remain the same. Appendix A provides a detailed discussion of the changes made to the models between last year's versions (Fu, Feldman, and Margolis 2018) and this year's versions. 


\section{References}

Ardani, Kristen, Jeffrey J. Cook, Ran Fu, and Robert Margolis. 2018. Cost-Reduction Roadmap for Residential Solar Photovoltaics (PV), 2017-2030. Golden, CO: National Renewable Energy Laboratory. NREL/TP-6A20-70748. https:/www.nrel.gov/docs/fy18osti/70748.pdf.

Ardani, Kristen, Eric O’Shaughnessy, Ran Fu, Chris McClurg, Joshua Huneycutt, and Robert Margolis. 2017. Installed Cost Benchmarks and Deployment Barriers for Residential Solar Photovoltaics with Energy Storage: Q1 2016. Golden, CO: National Renewable Energy Laboratory. NREL/TP-7A20- 67474. https://www.nrel.gov/docs/fy17osti/67474.pdf.

Balducci, Patrick J., M. Jan E. Alam, Trevor D. Hardy, and Di Wu. 2018. “Assigning Value to Energy Storage Systems at Multiple Points in an Electrical Grid.” Energy Environ. Sci. 11: 1926.

Barbose, Galen, and Naïm Darghouth. 2019. Tracking the Sun: Pricing and Design Trends for Distributed Photovoltaic Systems in the United States: 2019 Edition. Berkeley, CA: Lawrence Berkeley National Laboratory. https://emp.lbl.gov/tracking-the-sun.

Bloomberg. 2018. Bloomberg Professional Services. Accessed May 20, 2018: https://www.bloomberg.com/professional/.

BLS (U.S. Bureau of Labor Statistics). 2019. "National Occupational Employment and Wage Estimates United States." Accessed October 18, 2019:

https://www.bls.gov/oes/current/oes_nat.htm.

BNEF (Bloomberg New Energy Finance). 2019a. "2019 Lithium-Ion Battery Price Survey." December 3, 2019.

—. 2019b. "Energy Storage System Costs Survey 2019.” October 14, 2019.

_. 2019c. "LCOE Data: Current LCOE Range (\$/MWh, Nominal): United States, 2019 H2."

. 2018. "Energy Storage System Costs Survey 2019.” September 4, 2018.

Bolinger, Mark, Joachim Seel, and Dana Robson. 2019. Utility-Scale Solar: Empirical Trends in Project Technology, Cost, Performance, and PPA Pricing in the United States: 2019 Edition. Berkeley, CA: Lawrence Berkeley National Laboratory. https://emp.lbl.gov/publications/utilityscale-solar-empirical-trends.

CA NEM (California net energy metering). 2020. "NEM Currently Interconnected Data Set." Accessed August 11, 2020: http://www.californiadgstats.ca.gov/downloads.

Case, Tyler. 2012. "US Cost of Doing Business: Costs Fall in 2010.” Moody's Analytics Regional Financial Review, September 2012.

Chung, Donald, Carolyn Davidson, Ran Fu, Kristen Ardani, and Robert Margolis. 2015. U.S. Photovoltaic Prices and Cost Breakdowns: Q1 2015 Benchmarks for Residential, Commercial, and Utility-Scale Systems. NREL/TP-6A20-64746. Golden, CO: National Renewable Energy Laboratory. https://www.nrel.gov/docs/fy15osti/64746.pdf. 
Darghouth, Naïm, Galen Barbose, and Andrew Mills. 2019. Implications of Rate Design for the Customer-Economics of Behind-the-Meter Storage. Berkeley, CA: Lawrence Berkeley National Laboratory. https://emp.lbl.gov/publications/implications-rate-design-customer.

Denholm, Paul, Josh Eichman, and Robert Margolis. 2017. Evaluating the Technical and Economic Performance of PV Plus Storage Power Plants. NREL/TP-6A20-68737. Golden, CO: National Renewable Energy Laboratory. https:/www.nrel.gov/docs/fy17osti/68737.pdf.

Denholm, Paul, Jacob Nunemaker, Pieter Gagnon, and Wesley Cole. 2019. The Potential for Battery Energy Storage to Provide Peaking Capacity in the United States. NREL/TP-6A2074184. Golden, CO: National Renewable Energy Laboratory. https://www.nrel.gov/docs/fy19osti/74184.pdf.

DiOrio, Nicholas, Aron Dobos, and Steven Janzou. 2015. Economic Analysis Case Studies of Battery Energy Storage with SAM. NREL/TP-6A20-64987. Golden, CO: National Renewable Energy Laboratory. https://www.nrel.gov/docs/fy16osti/64987.pdf.

DiOrio, Nicholas, and Will Hobbs. 2018. Economic Dispatch for DC-Connected Battery Systems on Large PV Plants. 10th PVPMC, Albuquerque, NM. https://pvpmc.sandia.gov/download/6559/.

EIA (United States Energy Information Administration). 2020. "2019ER Form EIA-860 detailed data with previous form data." Released June 2, 2020. Washington, DC: EIA.

Enphase. 2019. Enphase quarterly presentations. Accessed October 14, 2019: https://investor.enphase.com/events-and-presentations

EuPD Research and Green Tech Media. 2016. “PV Installer Survey USA 2015/16.” Accessed October 2016.

Feldman, David, Mark Bolinger, and Paul Schwabe. 2020. Current and Future Costs of Renewable Energy Project Finance Across Technologies. NREL/TP-6A20-76881. Golden, CO: National Renewable Energy Laboratory. https:/www.nrel.gov/docs/fy20osti/76881.pdf.

Feldman, David, Rebecca Jones-Albertus, and Robert Margolis. 2018. Impact of Research and Development, Analysis, and Standardization on PV Project Financing Costs. NREL/TP6A20-70939. Golden, CO: National Renewable Energy Laboratory. https://www.nrel.gov/docs/fy18osti/70939.pdf.

Feldman, David, Galen Barbose, Robert Margolis, Mark Bolinger, Donald Chung, Ran Fu, Joachim Seel, Carolyn Davidson, Naïm Darghouth, and Ryan Wiser. 2015. Photovoltaic System Pricing Trends: Historical, Recent, and Near-Term Projections: 2015 Edition. NREL/PR-6A2064898. Golden, CO: National Renewable Energy Laboratory. https://www.nrel.gov/docs/fy15osti/64898.pdf.

Feldman, David, Barry Friedman, and Robert Margolis. 2013. Financing, Overhead, and Profit: An In-Depth Discussion of Costs Associated with Third-Party Financing of Residential and Commercial Photovoltaic Systems. NREL/TP-6A20-60401._Golden, CO: National Renewable Energy Laboratory. https://www.nrel.gov/docs/fy14osti/60401.pdf.

Feldman, David, and Paul Schwabe. 2018. Terms, Trends, and Insights on PV Project Finance in the United States, 2018. NREL/TP-6A20-72037. Golden, CO: National Renewable Energy Laboratory. https://www.nrel.gov/docs/fy19osti/72037.pdf. 
Feldman, David, and Paul Schwabe. 2017. Terms, Trends, and Insights: PV Project Finance in the United States, 2017. Golden, CO: National Renewable Energy Laboratory. NREL/TP-6A2070157. https://www.nrel.gov/docs/fy18osti/70157.pdf.

Feldman, David, Travis Lowder, and Paul Schwabe. 2016. Terms, Trends, and Insights: PV Project Finance in the United States, 2016. NREL/BR-6A20-66991. Golden, CO: National Renewable Energy Laboratory. http://www.nrel.gov/docs/fy16osti/66991.pdf.

Fitzgerald, Garrett, James Mandel, Jesse Morris, and Herve Touati. 2015. The Economics of Battery Energy Storage: How Multi-Use, Customer-Sited Batteries Deliver the Most Services and Value to Customers and the Grid. Rocky Mountain Institute. https://rmi.org/wpcontent/uploads/2017/03/RMI-TheEconomicsOfBatteryEnergyStorage-FullReport-FINAL.pdf.

Frew, Bethany, Wesley Cole, Nina Vincent, Andrew Reimers, and Robert Margolis. 2018. Impact of Dynamic Storage Capacity Valuation in Capacity Expansion Models: Preprint. NREL/CP-6A20-71462. Golden, CO: National Renewable Energy Laboratory. https://www.nrel.gov/docs/fy18osti/71462.pdf.

Fu, Ran, David Feldman, and Robert Margolis. 2018. U.S. Solar Photovoltaic System Cost Benchmark: Q1 2018. NREL/TP-6A20-72399. Golden, CO: National Renewable Energy Laboratory. https://www.nrel.gov/docs/fy19osti/72399.pdf.

Fu, Ran, Timothy Remo, and Robert Margolis. 2018. 2018 U.S. Utility-Scale Photovoltaics-PlusEnergy Storage System Costs Benchmark. NREL/TP-6A20-71714. Golden, CO: National Renewable Energy Laboratory. https://www.nrel.gov/docs/fy19osti/71714.pdf.

Fu, Ran, David Feldman, Robert Margolis, Mike Woodhouse, and Kristen Ardani. 2017. U.S. Solar Photovoltaic System Cost Benchmark: Q1 2017. NREL/TP-6A20-68925. Golden, CO: National Renewable Energy Laboratory. https:/www.nrel.gov/docs/fy17osti/68925.pdf.

$\mathrm{Fu}$, Ran, Donald Chung, Travis Lowder, David Feldman, Kristen Ardani, and Robert Margolis. 2016. U.S. Solar Photovoltaic System Cost Benchmark: Q1 2016. NREL/TP-6A2066532._Golden, CO: National Renewable Energy Laboratory. https://www.nrel.gov/docs/fy16osti/66532.pdf.

Fu, Ran, Ted L. James, Donald Chung, Douglas Gagne, Anthony Lopez, and Aron Dobos. 2015. "Economic Competitiveness of U.S. Utility-Scale Photovoltaic Systems in 2015: Regional Cost Modeling of Installed Cost $(\$ / \mathrm{W})$ and LCOE $(\$ / \mathrm{kWh})$." Presented at the IEEE 42nd Photovoltaic Specialist Conference, New Orleans, LA. https://ieeexplore.ieee.org/document/7356261.

Gunda, T., and R. Homan. (Forthcoming). Evaluation of Component Reliability in Photovoltaic Systems using Field Failure Statistics. Albuquerque, NM: Sandia National Laboratories.

Klise, G., O. Lavrova, and R. Gooding. 2018. PV System Component Fault and Failure Compilation and Analysis. SAND Report No. 2018-1743. Albuquerque, NM: Sandia National Laboratories. https://prod-ng.sandia.gov/techlib-noauth/access-control.cgi/2018/181743.pdf.

Lazard. 2018. Lazard's Levelized Cost of Storage Analysis: Version 4.0. November 2018.

MEPS International Ltd. 2019. "MEPS: North American Carbon Steel Purchasing Price Index (SPPI)." Accessed October 18, 2019. http://www.meps.co.uk/N.Amer\%20Index.htm. 
NEMA (National Electrical Manufacturers Association). 2020. Implementation of the National Electrical Code, NEMA Field Representatives. April 1, 2020. Accessed June 23, 2020. https://www.nema.org/Technical/FieldReps/Documents/Adoption $\% 20$ of $\% 20$ the $\% 20 \mathrm{National} \% 2$ 0Electrical\%20Code \%20by\%20State\%20or\%201ocal\%20jurisdiction.pdf.

NREL (National Renewable Energy Laboratory). 2020. NREL dialogues and interviews with solar industry collaborators. Golden, CO: National Renewable Energy Laboratory.

NREL (National Renewable Energy Laboratory), Sandia National Laboratories, SunSpec Alliance, and the SunShot National Laboratory Multiyear Partnership (SuNLaMP) PV O\&M Best Practices Working Group. 2018. Best Practices for Operation and Maintenance of Photovoltaic and Energy Storage Systems, 3rd Edition. NREL/TP-7A40-73822. Golden, CO: National Renewable Energy Laboratory. https:/www.nrel.gov/docs/fy19osti/73822.pdf.

PVinsights. 2019. PVinsights database. Accessed October 14, 2019: http://pvinsights.com. . 2020. PVinsights database. Accessed August 1, 2020.

RSMeans. 2017. RSMeans Building Construction Cost Data 2017. RS Means Catalog No. 60012 .

Schmidt, Oliver, Sylvain Melchior, Adam Hawkes, and Iain Staffell. 2019. "Projecting the Future Levelized Cost of Electricity Storage Technologies.” Joule 3(1): 81-100.

SolarEdge. 2019. SolarEdge quarterly presentations. Accessed October 14, 2019: https://investors.solaredge.com/financial-information/presentations

Sonnen Batterie. 2018. "Sonnen Batterie Smart Energy Storage for Homeowners.” Accessed April 10, 2018: https://sonnen-batterie.com/en-us/sonnenbatterie.

Sunrun. 2020. Sunrun quarterly presentations. Accessed August 1, 2020:

Tesla. 2020. Tesla quarterly presentations. Accessed August 1, 2020: https://ir.tesla.com/events

Vivint Solar. 2020. Vivint Solar quarterly presentations. Accessed August 1, 2020:

http://investors.vivintsolar.com/company/investors/events-andpresentations/presentations/default.aspx.

Walker, Andy, Eric Lockhart, Jal Desai, Kristen Ardani, Geoff Klise, Olga Lavrova, Tom Tansy, Jessie Deot, Bob Fox, and Anil Pochiraju. 2020. Model of Operation and Maintenance Costs for Photovoltaic Systems. NREL/TP-5C00-74840. Golden, CO: National Renewable Energy Laboratory. https://www.nrel.gov/docs/fy20osti/74840.pdf.

Wiser, Ryan H, Mark Bolinger, and Joachim Seel. 2020. "Benchmarking Utility-Scale PV Operational Expenses and Project Lifetimes: Results from a Survey of U.S. Solar Industry Professionals.” Berkeley, CA: Lawrence Berkeley National Laboratory. https://emp.lbl.gov/publications/benchmarking-utility-scale-pv.

Wood Mackenzie and SEIA (Solar Energy Industries Association). 2020. U.S. Solar Market Insight Report, Q2 2020. Washington, D.C.: Solar Energy Industries Association. https://www.woodmac.com/research/products/power-and-renewables/us-solar-market-insight/. 
. 2018. U.S. Solar Market Insight Report, Q2 2018. Washington, D.C.: Solar Energy Industries Association. https://www.woodmac.com/research/products/power-and-renewables/ussolar-market-insight/.

Wood Mackenzie. 2020. The Global PV Inverter and MLPE Landscape, H1 2020.

. 2019. Solar-Plus-Storage System Architectures: Design, Pricing, and Economics in the U.S.

—. 2014a. The Microinverter and DC Optimizer Landscape 2014. January 2014.

. 2014b. The Microinverter and DC Optimizer Landscape 2014, Updated March 2014. March 2014. 


\section{Appendix A. Changes in Methodology Between Q1 2018 and Q1 2020 Reports}

Since 2010, NREL has performed PV system benchmark calculations. Each year we endeavor to improve the modeling to better characterize the U.S. market and the costs associated with installing (and operating, in the case of LCOE) residential, commercial, and utility-scale PV systems. This year, to better distinguish the historical cost trends from the changes to our cost models, we also calculate Q1 2019 and Q1 2020 PV benchmarks using the Q1 2018 versions of the residential, commercial, and utility-scale standalone PV models. This appendix summarizes the major changes we made in the models between the publication of the Q1 2018 and Q1 2020 reports.

\section{Different Data Sources}

We changed our data sources for several inputs to (1) create more consistency and transparency across years, and (2) incorporate sources that include data from a larger part of the U.S. market. Table A-1 summarizes the differences in data sources and the associated inputs in benchmarking PV system costs between this year's report and the 2018 report.

Table A-1. Comparison of Input Assumptions and Sources in the Q1 2018 Benchmark Report and the Q1 2020 Benchmark Report

\begin{tabular}{|c|c|c|}
\hline Model Input & Q1 2018 Model: Sources & Q1 2020 Model: Sources \\
\hline Inverter cost & $\begin{array}{l}\text { PVinsights (2019, 2020) for string } \\
\text { and central inverters; public } \\
\text { corporate filings from Enphase } \\
\text { (2019) and SolarEdge }(2019) \text { were } \\
\text { used to calculate costs for } \\
\text { microinverters and DC optimizers, } \\
\text { respectively, using revenue per watt } \\
\text { shipped. Q1 2019: } \$ 0.12 / \mathrm{W} \\
\text { residential string inverters; } \$ 0.24 / \mathrm{W} \\
\text { power optimizers plus string } \\
\text { inverters; } \$ 0.36 / \mathrm{W} \text { microinverters; } \\
\$ 0.06 / \mathrm{W} \text { commercial; } \$ 0.04 / \mathrm{W} \\
\text { utility-scale. Q1 2020: } \$ 0.10 / \mathrm{W} \\
\text { residential string inverters; } \$ 0.23 / \mathrm{W} \\
\text { power optimizers plus string } \\
\text { inverters; } \$ 0.35 / \mathrm{W} \text { microinverters; } \\
\$ 0.05 / \mathrm{W} \text { commercial; } \$ 0.03 / \mathrm{W} \\
\text { utility-scale. }\end{array}$ & $\begin{array}{l}\text { Wood Mackenzie and SEIA (2020) } \\
\text { for all inverter types; the switch to } \\
\text { one data source provides more } \\
\text { consistency across years and } \\
\text { between sectors. Q1 2019: } \$ 0.14 / \mathrm{W} \\
\text { residential string inverters; } \$ 0.30 / \mathrm{W} \\
\text { residential power optimizers plus } \\
\text { string inverters; } \$ 0.34 / \mathrm{W} \\
\text { microinverters; } \$ 0.09 / \mathrm{W} \text { three- } \\
\text { phase commercial; } \$ 0.15 / \mathrm{W} \text { three- } \\
\text { phase commercial with power } \\
\text { optimizers; } \$ 0.06 / \mathrm{W} \text { utility-scale. Q1 } \\
\text { 2020: } \$ 0.15 / \mathrm{W} \text { residential string } \\
\text { inverters; } \$ 0.30 / \mathrm{W} \text { residential power } \\
\text { optimizers plus string inverters; } \\
\$ 0.34 / \mathrm{W} \text { microinverters; } \$ 0.078 / \mathrm{W} \\
\text { three-phase commercial; } \$ 0.14 / \mathrm{W} \\
\text { three-phase commercial with power } \\
\text { optimizers; } \$ 0.069 / \mathrm{W} \text { utility-scale. }\end{array}$ \\
\hline Module efficiency & $\begin{array}{l}\text { California's NEM Interconnected } \\
\text { Data Set, using average module } \\
\text { power for the previous year's PV } \\
\text { system in the residential sector for } \\
\text { the residential PV model- } 311 \\
\text { watts-peak ( } \mathrm{W}_{\mathrm{p}}, 2018 \text { ) and } 319 \mathrm{~W}_{\mathrm{p}} \\
\text { (2019)—divided by the average }\end{array}$ & $\begin{array}{l}\text { California's NEM Interconnected } \\
\text { Data Set, using capacity-weighted } \\
\text { average module efficiency of } 60 \text {-cell } \\
\text { and } 72 \text {-cell monocrystalline or } \\
\text { multicrystalline modules for PV } \\
\text { systems installed in that year. } \\
\text { Monocrystalline: } 19.2 \% \text { (2019) and }\end{array}$ \\
\hline
\end{tabular}




\begin{tabular}{|c|c|c|}
\hline Model Input & Q1 2018 Model: Sources & Q1 2020 Model: Sources \\
\hline & $\begin{array}{l}\text { module size for the entire data set } \\
\left(1.64 \mathrm{~m}^{2}(2018) \text { and } 1.65 \mathrm{~m}^{2}\right. \\
(2019)) \text {, giving an estimated module } \\
\text { efficiency in residential PV systems } \\
\text { of } 19.0 \% \text { (2018) and } 19.4 \%(2019) \text {. } \\
\text { Using average module power for the } \\
\text { previous year's PV system in the } \\
\text { commercial sector for the } \\
\text { commercial PV model ( } 330 \mathrm{~W}_{\mathrm{p}} \\
\left.(2018) \text { and } 343 \mathrm{~W}_{\mathrm{p}}(2019)\right) \text {, divided } \\
\text { by the average module size for the } \\
\text { entire data set }\left(1.64 \mathrm{~m}^{2}(2018) \text { and }\right. \\
\left.1.65 \mathrm{~m}^{2}(2019)\right) \text {, giving an estimated } \\
\text { module efficiency in commercial PV } \\
\text { systems of } 20.1 \%(2018) \text { and } 20.8 \% \\
(2019) \text {. }\end{array}$ & $\begin{array}{l}\text { 19.5\% (Q1 2020). Multicrystalline: } \\
\text { 17.3\% (2019) and } 17.4 \% \\
\text { (Q1 2020). }\end{array}$ \\
\hline Module price & $\begin{array}{l}\text { Market-share-weighted-average } \\
\text { monocrystalline and multicrystalline } \\
\text { spot price from Wood Mackenzie } \\
\text { and SEIA (2020) in the first quarter } \\
\text { of the year. Q1 2019: \$0.39/W. Q1 } \\
\text { 2020: \$0.38/W. }\end{array}$ & $\begin{array}{l}\text { U.S. monocrystalline silicon spot } \\
\text { price from Wood Mackenzie and } \\
\text { SEIA (2020) in the first quarter of } \\
\text { the year. Q1 2019: } \$ 0.40 / \mathrm{W} \text {. } \\
\text { Q1 2020: } \$ 0.41 / \mathrm{W} \text {. }\end{array}$ \\
\hline $\begin{array}{l}\text { Residential inverter } \\
\text { market share }\end{array}$ & $\begin{array}{l}\text { California's NEM Interconnection } \\
\text { Data Set, using the percentage of } \\
\text { market penetration of the previous } \\
\text { year (by installed capacity), } \\
\text { assuming all microinverters were } \\
\text { represented by Enphase inverters, } \\
\text { DC optimizers were represented by } \\
\text { SolarEdge inverters, and the } \\
\text { remainder were string inverters. } \\
\text { Residential market share of string } \\
\text { inverters, power optimizers, and } \\
\text { microinverters: } 2018(61.8 \%, 16.8 \% \text {, } \\
21.4 \%) ; 2019(59.2 \%, 18.8 \% \text {, } \\
22.0 \%) \text {. }\end{array}$ & $\begin{array}{l}\text { Tracking the Sun data set; } \\
\text { these data include a broader } \\
\text { representation of the United States } \\
\text { than just California. Residential } \\
\text { market share of string inverters, } \\
\text { power optimizers, and } \\
\text { microinverters for latest year } \\
\text { available: } 2018 \text { (used for both } \\
\text { Q1 } 2019 \text { and Q1 } 2020 \text { benchmark): } \\
14.6 \%, 49.8 \% \text {, and } 35.6 \% \text {. }\end{array}$ \\
\hline $\begin{array}{l}\text { Residential business } \\
\text { structure market share }\end{array}$ & $\begin{array}{l}\text { Corporate filings from Sunrun } \\
\text { (2020), Tesla (2020), and Vivint } \\
\text { Solar (2020) to estimate national } \\
\text { integrator Q1 } 2019 \text { (33\%) and Q1 } \\
2020(30 \%) \text { market share; Wood } \\
\text { Mackenzie and SEIA (2020) to } \\
\text { estimate the remainder, classified } \\
\text { small installers. }\end{array}$ & $\begin{array}{l}\text { TPO market share from Tracking } \\
\text { the Sun data set to estimate } \\
\text { national integrator market share, } \\
\text { with the remainder classified as } \\
\text { small installers; the TPO data } \\
\text { include other national integrators } \\
\text { besides Sunrun, Tesla, and Vivint. } \\
\text { The } 2018 \text { (latest year available) } \\
\text { TPO market share of } 38 \% \text { is used } \\
\text { for both Q1 } 2019 \text { and Q1 } 2020 \text {. }\end{array}$ \\
\hline
\end{tabular}




\section{Different Methodology for Calculating Residential Overhead, Customer Acquisition, and PII}

In this year's version of our benchmark analysis, we expand our modeling of customer acquisition, engineering, PII, and overhead. In addition to providing finer granularity to costs, we include costs borne by many installers throughout the United States. Table A-2 summarizes the current and previous methods.

Table A-2. Comparison of Methods for Calculating Q1 2018 Residential PV Soft Costs in the Q1 2018 Benchmark Report and the Q1 2020 Benchmark Report

\section{Residential Soft Cost \\ Q1 2018 Model: Summary of Method (Value)}

PII
A permit fee of $\$ 200$ and six hours of staff time $(\$ 0.05 / \mathrm{W})$.
Q1 2020 Model: Summary of Method (Value)
An itemized list of steps and associated labor and other costs needed to design the initial and final system plans, apply for and receive a permit and interconnection agreement, multiplied by the estimated percentage of national sales that use this step, divided by the average conversion from this step to an installed system (to account for the cost of lost sales) $(\$ 0.24 / \mathrm{W})$. Many of these costs were not captured in previous editions.
Sales and marketing (customer acquisition)
Data from the 2013 report (Feldman et al. 2013), which calculated sales and marketing costs by estimating the headcount, salaries, benefits, and taxes of the sales, engineering, and marketing departments, as well as vehicle costs $(\$ 0.37 / \mathrm{W})$.
An estimated breakdown of the necessary steps and associated labor and other costs of customer acquisition, including advertisement, lead generation, qualifications/first sales pitch, and final sales pitch. Each possible customer acquisition pathway is multiplied by the estimated percentage of national sales that use this step, divided by the average conversion from this step to an installed system (to account for the cost of lost sales) $(\$ 0.43 / \mathrm{W})$.

An update of previous cost categories, including the overhead of the larger staff associated with customer acquisition and PII; the model also assumes $10 \%$ is added to the base salary to account for training expenses $(\$ 0.27 / \mathrm{W})$.

Overhead
(general and
administrative)

Data from the 2013 report (Feldman et al. 2013), which calculated overhead costs by estimating the headcount, salaries, benefits, and taxes of the management, human resources, project management, administration, supply chain, information technology, and customer service departments, as well as rent and other office expenses, professional services, insurance, taxes, dues, and memberships $(\$ 0.34 / \mathrm{W})$. 


\section{Incorporation of MLPE into the Commercial Rooftop PV Model}

MLPE are growing to be a substantial part of the commercial PV rooftop market in the United States owing in part to the adoption by many states of the 2017 NEC, which requires rooftop PV systems to have module-level rapid shutdown. In past years, we only assumed string inverters for the commercial PV benchmark, only weighting the residential PV system benchmark by MLPE market share. This year, we also weight the commercial rooftop PV benchmark by MLPE market share (45\% for three-phase string inverters, $39 \%$ for power optimizers, and $16 \%$ for microinverters).

\section{Annual Updates of Installation Labor Rates}

In previous year's models, we adjusted the 2012 labor rates by inflation, using the CPI "All Urban Consumers" series. For this year's model, we pull each year's labor rate directly from the Bureau of Labor Statistics.

\section{Elimination of State Variations from the Cost of Doing Business}

In previous year's models, we adjusted installation labor rates and supply chain costs for each state by the state's cost of doing business, as reported by Case (2012). For this year's report, we do not use a cost of doing business adjustment because all costs are use national averages.

\section{Changes to Calculating Number of Modules in Commercial and Utility-Scale PV Models}

Previous year's models calculated the number of modules in a system by dividing system size by $310.4 \mathrm{~W}$, rounded to the nearest whole number. We update the model to calculate the number of modules by dividing system size by module efficiency and module area, and rounding any fraction up to the closest whole number.

\section{Changes to the Cost Classification of Land Acquisition for Utility-Scale PV Models}

For previous editions of this report, we assumed a land acquisition cost of $\$ 0.03 / \mathrm{W}$. Based on Wiser et al. (2020), which stated that most utility-scale PV projects do not own the land on which the PV system is placed, we reclassify land costs from an upfront capital expenditure (land acquisition) to an operating expenditure (lease payments) for 2019 and 2020.

\section{Switching from Weighting Costs by State PV Installation Levels}

In previous year's models, our national average benchmarks were calculated by weighting the state averages of sales tax, labor rates, wind load, snow load, and material and equipment location factor by the amount of PV capacity installed in each state in the previous year for that sector (utility-scale, commercial, residential). We update the model to use national average labor rates and the average values of state sales tax, wind load, snow load, and material and equipment location factor.

\section{Changes to Reported Dollar Year Calculation}

In previous year's models, we adjusted values for inflation based on a partial year of CPI data. For example, in the Q1 2018 benchmark report (Fu, Feldman, and Margolis 2018), all values are quoted in \$2018; however, the inflation adjustment is based on the average CPI Index of Q1 2018 (January through March 2018). Because the benchmark reports are produced before the end of the calendar year, indexing them in that year is not possible. To better correct for inflation, in this year's report, we quote values in previous year’s dollars (\$2019). In 2018, the CPI-All Urban 
Consumers Index is 248.8 for the first three months and 251.1 for the whole year (and 255.7 for 2019).

The changes summarized in this appendix result in Q1 2019 and Q1 2020 benchmarks with different results than would have been calculated using the previous edition's models and assumptions. For example, the 2020 total residential PV installed-cost benchmark calculated using the Q1 2018 model is $\$ 2.47 / \mathrm{W}_{\mathrm{DC}}$, whereas the same benchmark calculated using the Q1 2020 model is $\$ 2.71 / \mathrm{W}_{\mathrm{DC}}(7 \%$ higher $)$.

Table A-3 summarizes the impacts these changes have on each cost category in the residential, commercial, and utility-scale PV benchmarks for Q1 2020. 
Table A-3. Comparison of Q1 2020 Benchmark Costs, per Category, Calculated Using Previous Report's Model (Q1 2018) and the Current Model (Q1 2020) in 2019 USD

\begin{tabular}{|c|c|c|c|c|c|c|c|c|c|c|c|c|}
\hline & \multicolumn{3}{|c|}{$\begin{array}{l}\text { Residential PV } \\
\text { (2020) }\end{array}$} & \multicolumn{3}{|c|}{$\begin{array}{l}\text { Commercial Rooftop PV } \\
(2020)\end{array}$} & \multicolumn{3}{|c|}{$\begin{array}{l}\text { Utility-Scale, Fixed-Tilt } \\
(2020)\end{array}$} & \multicolumn{3}{|c|}{$\begin{array}{l}\text { Utility-Scale, One-Axis } \\
(2020)\end{array}$} \\
\hline & $\begin{array}{l}\text { Q1 } 2018 \\
\text { Model }\end{array}$ & $\begin{array}{l}\text { Q1 } 2020 \\
\text { Model }\end{array}$ & $\begin{array}{c}\% \\
\text { Change }\end{array}$ & $\begin{array}{c}\text { Q1 } \\
2018 \\
\text { Model }\end{array}$ & $\begin{array}{l}\text { Q1 } 2020 \\
\text { Model }\end{array}$ & $\begin{array}{c}\% \\
\text { Change }\end{array}$ & $\begin{array}{c}\text { Q1 } 2018 \\
\text { Model }\end{array}$ & $\begin{array}{l}\text { Q1 } 2020 \\
\text { Model }\end{array}$ & $\begin{array}{c}\% \\
\text { Change }\end{array}$ & $\begin{array}{c}\text { Q1 } 2018 \\
\text { Model }\end{array}$ & $\begin{array}{l}\text { Q1 } 2020 \\
\text { Model }\end{array}$ & $\begin{array}{c}\% \\
\text { Change }\end{array}$ \\
\hline Module & $\$ 0.376$ & $\$ 0.406$ & $5 \%$ & $\$ 0.376$ & $\$ 0.406$ & $5 \%$ & $\$ 0.376$ & $\$ 0.406$ & $5 \%$ & $\$ 0.376$ & $\$ 0.406$ & $5 \%$ \\
\hline Inverter & $\$ 0.217$ & $\$ 0.250$ & $12 \%$ & $\$ 0.045$ & $\$ 0.123$ & $169 \%$ & $\$ 0.022$ & $\$ 0.051$ & $127 \%$ & $\$ 0.022$ & $\$ 0.052$ & $127 \%$ \\
\hline Structural BOS & $\$ 0.084$ & $\$ 0.084$ & $-3 \%$ & $\$ 0.112$ & $\$ 0.110$ & $-4 \%$ & $\$ 0.087$ & $\$ 0.080$ & $-10 \%$ & $\$ 0.130$ & $\$ 0.122$ & $-9 \%$ \\
\hline Electrical BOS & $\$ 0.190$ & $\$ 0.228$ & $17 \%$ & $\$ 0.133$ & $\$ 0.133$ & $-3 \%$ & $\$ 0.088$ & $\$ 0.073$ & $-19 \%$ & $\$ 0.088$ & $\$ 0.073$ & $-19 \%$ \\
\hline Supply chain costs & $\$ 0.254$ & $\$ 0.261$ & $0 \%$ & - & - & - & - & - & - & - & - & - \\
\hline Installation labor & $\$ 0.242$ & $\$ 0.187$ & $-25 \%$ & $\$ 0.159$ & $\$ 0.148$ & $-9 \%$ & $\$ 0.094$ & $\$ 0.102$ & $5 \%$ & $\$ 0.102$ & $\$ 0.111$ & $6 \%$ \\
\hline PII & $\$ 0.050$ & $\$ 0.238$ & $366 \%$ & $\$ 0.100$ & $\$ 0.106$ & $3 \%$ & $\$ 0.033$ & $\$ 0.030$ & $-13 \%$ & $\$ 0.033$ & $\$ 0.030$ & $-13 \%$ \\
\hline $\begin{array}{l}\text { Transmission Line } \\
\text { (if any) }\end{array}$ & 一 & - & - & - & - & - & $\$ 0.019$ & $\$ 0.017$ & $-13 \%$ & $\$ 0.019$ & $\$ 0.017$ & $-13 \%$ \\
\hline $\begin{array}{l}\text { Sales and marketing } \\
\text { (customer acquisition) }\end{array}$ & $\$ 0.360$ & $\$ 0.428$ & $15 \%$ & - & - & - & - & - & - & - & - & - \\
\hline Overhead & $\$ 0.327$ & $\$ 0.274$ & $-18 \%$ & $\$ 0.526$ & $\$ 0.492$ & $-8 \%$ & $\$ 0.068$ & $\$ 0.068$ & $-3 \%$ & $\$ 0.077$ & $\$ 0.076$ & $-3 \%$ \\
\hline Contingency & - & - & - & $\$ 0.040$ & $\$ 0.044$ & $7 \%$ & $\$ 0.024$ & $\$ 0.026$ & $3 \%$ & $\$ 0.026$ & $\$ 0.027$ & $2 \%$ \\
\hline Profit & $\$ 0.296$ & $\$ 0.292$ & $-4 \%$ & $\$ 0.107$ & $\$ 0.113$ & $2 \%$ & $\$ 0.042$ & $\$ 0.045$ & $2 \%$ & $\$ 0.046$ & $\$ 0.048$ & $2 \%$ \\
\hline Sales tax & $\$ 0.077$ & $\$ 0.063$ & $-21 \%$ & $\$ 0.045$ & $\$ 0.046$ & $1 \%$ & $\$ 0.038$ & $\$ 0.041$ & $4 \%$ & $\$ 0.041$ & $\$ 0.043$ & $4 \%$ \\
\hline Total price & $\$ 2.474$ & $\$ 2.710$ & $7 \%$ & $\$ 1.642$ & $\$ 1.720$ & $2 \%$ & $\$ 0.891$ & $\$ 0.937$ & $2 \%$ & $\$ 0.959$ & $\$ 1.005$ & $2 \%$ \\
\hline
\end{tabular}




\section{Appendix B. PV System LCOE Benchmarks in 2019 USD}

Table B-1. NREL LCOE Summary (2019 cents/kWh)

\begin{tabular}{|c|c|c|c|c|c|c|c|c|c|c|c|c|c|c|}
\hline \multirow[b]{2}{*}{ Reporting Year } & \multicolumn{11}{|c|}{ Market Financing Rates } & \multicolumn{3}{|c|}{$\begin{array}{l}\text { Steady- } \\
\text { State Financing }\end{array}$} \\
\hline & ํํํ & $\overline{\text { N }}$ & 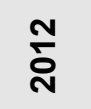 & $\sum_{N}^{m}$ & $\stackrel{⿱ 乛}{\text { N }}$ & $\stackrel{\text { N }}{\text { N }}$ & $\stackrel{\circ}{\grave{N}}$ & $\hat{\grave{n}}$ & $\sum_{N}^{\infty}$ & $\stackrel{\circ}{\grave{n}}$ & న్๊ి & న్రి & \multirow{2}{*}{$\begin{array}{l}\overline{\widetilde{\sigma}} \\
\text { Oे } \\
\text { ণิ } \\
\text { N }\end{array}$} & \multirow{2}{*}{ 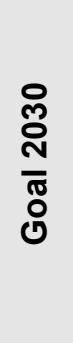 } \\
\hline Benchmark Date & $\begin{array}{l}\text { \&े } \\
\text { N } \\
\text { ठे }\end{array}$ & 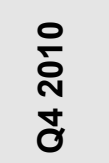 & $\begin{array}{l}\overline{\grave{j}} \\
\text { ơ }\end{array}$ & $\begin{array}{l}\text { N. } \\
\text { N } \\
\text { Ȯ }\end{array}$ & $\begin{array}{l}\stackrel{m}{\tilde{N}} \\
\text { Oे }\end{array}$ & $\begin{array}{l}\stackrel{\infty}{\grave{2}} \\
\bar{\sigma}\end{array}$ & $\begin{array}{l}0 \\
\stackrel{\circ}{N} \\
\bar{\sigma}\end{array}$ & $\begin{array}{l}\hat{\sigma} \\
\bar{N} \\
\overline{0}\end{array}$ & $\frac{\infty}{\grave{N}}$ & $\begin{array}{l}\stackrel{0}{\sigma} \\
\text { N } \\
\bar{\sigma}\end{array}$ & 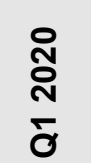 & $\begin{array}{l}\text { ণิ } \\
\text { N̦ } \\
\bar{\sigma}\end{array}$ & & \\
\hline \multicolumn{15}{|l|}{ Residential $(6.9 \mathrm{~kW})$} \\
\hline High resource (CF 21.6\%), no ITC & 41.6 & 35.0 & 24.1 & 20.2 & 16.9 & 15.0 & 13.8 & 12.9 & 12.0 & 11.2 & 11.0 & 10.5 & - & - \\
\hline Medium resource (CF $17.6 \%$ ), no ITC & 50.9 & 42.8 & 29.5 & 24.7 & 20.8 & 18.4 & 16.9 & 15.8 & 14.8 & 13.7 & 13.5 & 12.8 & 10.6 & 5.3 \\
\hline Low resource (CF $16.4 \%$ ), no ITC & 54.7 & 46.0 & 31.7 & 26.6 & 22.3 & 19.7 & 18.1 & 17.0 & 15.9 & 14.7 & 14.5 & 13.8 & - & - \\
\hline High resource (CF 21.6\%), ITC & 27.6 & 23.2 & 16.1 & 13.5 & 11.3 & 9.9 & 9.1 & 8.6 & 8.0 & 7.1 & 7.1 & - & - & - \\
\hline Medium resource (CF $17.6 \%$ ), ITC & 33.9 & 28.4 & 19.8 & 16.5 & 13.8 & 12.1 & 11.2 & 10.5 & 9.8 & 8.7 & 8.7 & - & - & - \\
\hline Low resource (CF 16.4\%), ITC & 36.4 & 30.5 & 21.2 & 17.7 & 14.8 & 13.0 & 12.0 & 11.3 & 10.5 & 9.4 & 9.3 & - & - & - \\
\hline \multicolumn{15}{|l|}{ Commercial Rooftop (200 kW) } \\
\hline High resource (CF 20.4\%), no ITC & 32.0 & 28.5 & 19.2 & 15.2 & 14.3 & 11.5 & 10.7 & 9.2 & 8.9 & 7.9 & 7.7 & 7.3 & - & - \\
\hline Medium resource (CF 16.4\%), no ITC & 39.7 & 35.4 & 23.9 & 18.8 & 17.8 & 14.2 & 13.3 & 11.5 & 11.0 & 9.5 & 9.3 & 9.0 & 8.2 & 4.3 \\
\hline Low resource (CF $15.3 \%$ ), no ITC & 42.8 & 38.1 & 25.7 & 20.3 & 19.2 & 15.3 & 14.3 & 12.4 & 11.9 & 10.6 & 10.3 & 9.7 & - & - \\
\hline High resource (CF 20.4\%), ITC & 21.1 & 18.8 & 12.8 & 10.1 & 9.5 & 7.6 & 7.1 & 6.2 & 5.9 & 5.1 & 4.9 & - & - & - \\
\hline Medium resource (CF 16.4\%), ITC & 26.2 & 23.3 & 15.9 & 12.6 & 11.8 & 9.5 & 8.8 & 7.7 & 7.4 & 6.3 & 6.1 & - & - & - \\
\hline Low resource (CF 15.3\%), ITC & 28.2 & 25.1 & 17.1 & 13.5 & 12.7 & 10.2 & 9.5 & 8.3 & 7.9 & 6.8 & 6.6 & - & - & - \\
\hline
\end{tabular}




\begin{tabular}{|c|c|c|c|c|c|c|c|c|c|c|c|c|c|c|}
\hline \multicolumn{15}{|l|}{ Commercial Ground-Mount (500 kW) } \\
\hline High resource (CF 21.6\%), no ITC & 一 & 一 & - & 一 & - & 一 & 一 & 一 & 一 & 一 & 7.1 & 6.7 & - & - \\
\hline Medium resource (CF 17.6\%), no ITC & - & 一 & - & - & - & - & - & - & - & - & 8.7 & 8.2 & - & - \\
\hline Low resource (CF 16.4\%), no ITC & - & - & - & - & - & - & - & - & - & 一 & 9.3 & 8.8 & - & - \\
\hline High resource (CF 21.6\%), ITC & - & 一 & - & - & 一 & - & 一 & 一 & 一 & 一 & 4.5 & 一 & 一 & - \\
\hline Medium resource (CF $17.6 \%$ ), ITC & - & - & - & - & - & - & - & - & - & - & 5.6 & 一 & - & - \\
\hline Low resource (CF 16.4\%), ITC & - & - & - & - & - & - & - & - & - & - & 6.0 & - & - & - \\
\hline \multicolumn{15}{|c|}{ Utility-Scale (100 MW One-Axis Tracking) } \\
\hline High resource (CF 25.2\%), no ITC & 22.5 & 18.6 & 12.7 & 9.6 & 8.5 & 7.6 & 6.0 & 4.6 & 4.4 & 3.7 & 3.7 & 3.6 & - & - \\
\hline Medium resource (CF 19.6\%), no ITC & 28.9 & 23.9 & 16.4 & 12.4 & 10.9 & 9.8 & 7.8 & 5.9 & 5.6 & 4.7 & 4.7 & 4.6 & 6.4 & 3.2 \\
\hline Low resource (CF 18.2\%), no ITC & 31.4 & 26.0 & 17.8 & 13.4 & 11.8 & 10.6 & 8.4 & 6.4 & 6.1 & 5.1 & 5.1 & 4.9 & 一 & - \\
\hline High resource (CF $25.2 \%$ ), ITC & 13.9 & 11.5 & 8.0 & 6.1 & 5.4 & 4.8 & 3.9 & 3.1 & 3.0 & 2.5 & 2.5 & 一 & 一 & - \\
\hline Medium resource (CF 19.6\%), ITC & 17.9 & 14.8 & 10.3 & 7.8 & 6.9 & 6.2 & 5.0 & 3.9 & 3.8 & 3.3 & 3.3 & 一 & 一 & - \\
\hline Low resource (CF 18.2\%), ITC & 19.4 & 16.1 & 11.1 & 8.5 & 7.5 & 6.7 & 5.4 & 4.3 & 4.2 & 3.5 & 3.5 & 一 & 一 & - \\
\hline \multicolumn{15}{|l|}{ Utility-Scale (100 MW Fixed-Tilt) } \\
\hline High resource (CF 21.3\%), no ITC & 22.5 & 18.9 & 12.8 & 9.8 & 8.8 & 8.2 & 6.6 & 5.0 & 4.7 & 4.0 & 4.0 & 3.7 & - & - \\
\hline Medium resource (CF 17.3\%), no ITC & 27.7 & 23.2 & 15.7 & 12.0 & 10.8 & 10.1 & 8.1 & 6.1 & 5.8 & 4.9 & 4.9 & 4.6 & 一 & - \\
\hline Low resource (CF 16.2\%), no ITC & 29.6 & 24.8 & 16.9 & 12.9 & 11.5 & 10.8 & 8.7 & 6.5 & 6.2 & 5.2 & 5.2 & 4.9 & - & - \\
\hline High resource (CF 21.3\%), ITC & 14.0 & 11.7 & 8.1 & 6.2 & 5.6 & 5.2 & 4.2 & 3.3 & 3.0 & 2.5 & 2.5 & 一 & 一 & - \\
\hline Medium resource (CF 17.3\%), ITC & 17.2 & 14.4 & 9.9 & 7.6 & 6.8 & 6.4 & 5.2 & 4.0 & 3.7 & 3.1 & 3.1 & 一 & - & - \\
\hline Low resource (CF 16.2\%), ITC & 18.4 & 15.5 & 10.6 & 8.2 & 7.3 & 6.8 & 5.5 & 4.3 & 3.9 & 3.3 & 3.3 & - & - & - \\
\hline
\end{tabular}

a 2020 residential and commercial SETO goals are adjusted for inflation using the CPI; the 2020 utility-scale goal was left unchanged, because wholesale prices were relatively flat, and in some cases declined, from 2010 to 2020. 